\title{
CESSÃO FIDUCIÁRIA DE CRÉDITO E O SEU TRATAMENTO NAS HIPÓTESES DE RECUPERAÇÃO JUDICIAL E FALÊNCIA DO DEVEDOR-FIDUCIANTE
}

Dissertação de Mestrado sob a orientação do Prof. Dr. Paulo Fernando Campos Salles de Toledo.

Faculdade de Direito da Universidade de São Paulo

São Paulo

2010 


\section{CESSÃO FIDUCIÁRIA DE CRÉDITO E O SEU TRATAMENTO NAS HIPÓTESES DE RECUPERAÇÃO JUDICIAL E FALÊNCIA DO DEVEDOR-FIDUCIANTE}

Dissertação de Mestrado apresentada à banca examinadora da Faculdade de Direito da Universidade de São Paulo, como exigência parcial para obtenção do título de mestre, sob a orientação do Prof. Dr. Paulo Fernando Campos Salles de Toledo.

São Paulo

2010 
Banca Examinadora 


\section{AGRADECIMENTOS}

Agradeço aos meus pais, Emilia e Norberto Teixeira, pelo amor que me deram, pelos ensinamentos e pelo grande esforço que fizeram para que eu pudesse chegar até aqui. Agradeço ao meu marido, Humberto Alexandre Proença Pereira, pelo amor e, principalmente, pela paciência e força dadas durante todo o mestrado, sem os quais não teria sido possível seguir adiante. Agradeço à minha irmã, Luciana S. Teixeira, pelo amor demonstrado e pelas palavras de incentivo. Agradeço ao meu orientador, Prof. Paulo Fernando C. S. de Toledo, por ter acreditado no meu trabalho, pelas grandes lições dadas em nossas reuniões de orientação e por todas as palavras de incentivo e encorajamento durante toda esta trajetória, que foram essenciais para que eu não perdesse o rumo e nem desanimasse. Agradeço aos Professores Dr. Álvaro Villaça Azevedo e Dr. Haroldo Malheiros Duclerc Verçosa, que compuseram minha banca de qualificação, pelos comentários e sugestões feitas que muito ajudaram para o aperfeiçoamento do trabalho. Agradeço a todos os familiares e amigos pela paciência e compreensão quanto a minha completa falta de tempo e atenção. Agradeço, em especial, à amiga Mônica Longo de Oliveira que é uma inspiração para mim; à amiga de longa data, Luciana Eboli Guimarães, pela valiosa e fundamental ajuda com os trabalhos de pesquisa e revisão da dissertação; à amiga Mareska Tiveron Salge pelas valiosas discussões sobre cessão fiduciária; à amiga Oliara Fortunato pela ajuda com a revisão dos textos em inglês; ao amigo e chefe Neil Montgomery pela compreensão durante todo o período de mestrado; à amiga Evy Cynthia Marques pela força e pelo exemplo de disciplina que me foram tão úteis; ao amigo André de Melo Ribeiro pela constante ajuda; e ao amigo Marcus Alexandre Matteucci Gomes pelas discussões sobre direito civil. 
"A verdadeira origem da descoberta consiste não em procurar novas paisagens, mas em ter novos olhos."(Marcel Proust)

"Não se pode criar experiência. É preciso passar por ela." (Albert Camus) 


\section{RESUMO}

O objetivo primordial da presente dissertação é estudar o instituto da cessão fiduciária de créditos e de títulos de crédito, previsto no artigo 66-B da Lei nº 4.728, de 14 de julho de 1965, com a redação dada pela Lei $\mathrm{n}^{\circ} 10.931$, de 02 de agosto de.2004, e popularmente conhecida como "trava bancária", com vistas a identificar as posições da doutrina e jurisprudência quanto ao seu tratamento nas hipóteses de recuperação judicial e falência do devedor-fiduciante.

Isto porque, o parágrafo $3^{\circ}$ do artigo 49 da Lei $n^{\circ} 11.101$, de 09 de fevereiro de 2005 (“Lei de Recuperação de Empresas - LRE”) exclui dos efeitos da recuperação judicial os "proprietários fiduciários de bens móveis e imóveis". A maior parte da doutrina e da jurisprudência defende que os titulares de créditos cedidos fiduciariamente estão compreendidos na definição de "proprietário fiduciário de bem móvel" prevista no referido parágrafo $3^{\circ}$ do artigo 49 da LRE e, portanto, estão excluídos dos efeitos da recuperação judicial do devedor-fiduciante.

Por outro lado, parte minoritária da doutrina e da jurisprudência defende que o parágrafo $3^{\circ}$ do artigo 49 da LRE não menciona expressamente "os titulares de crédito cedidos fiduciariamente" e, sendo o referido parágrafo exceção à regra de que todos os credores estão sujeitos à recuperação judicial do devedor, sua redação deveria ser interpretada restritivamente, razão pela qual os credores titulares de créditos cedidos fiduciariamente estão sujeitos à recuperação judicial do devedor-fiduciante.

A divergência da doutrina e da jurisprudência sobre o tema acaba por acarretar insegurança jurídica quanto ao uso da cessão fiduciária como forma de garantia. De um lado, as instituições financeiras têm dúvidas sobre a real segurança de tal garantia, o que pode comprometer uma eficiente avaliação de risco de crédito, assim como a recuperação do crédito na hipótese de insolvência do devedor. Por outro lado, as empresas em crise têm dúvidas sobre a viabilidade de sua efetiva recuperação, principalmente quando seus maiores credores forem bancos. 
Por todos esses motivos, entendemos ser de suma importância um estudo aprofundado do referido instituto, bem como uma análise crítica da solução adotada pelo legislador em face dos princípios de preservação da empresa em crise trazidos pela LRE. 


\begin{abstract}
The main purpose of this dissertation is to examine the fiduciary assignment of rights on movable assets and of credit instruments, as contemplated in article 66-B of Law No. 4,728, of July 14, 1965, as amended by Law No. 10,931, of August 2, 2004 - widely known as "bank lock" (trava bancária) - with a view to identifying the standing of legal scholars and court precedents and their approach in the event of debtor's judicial restructuring and/or bankruptcy.
\end{abstract}

This is because the $3^{\text {rd }}$ paragraph of article 49 of Law No. 11,101 of February 9, 2005 ("Judicial Restructuring Law - LRE") determines that the "fiduciary owners of movable and immovable assets" are no longer subject to the effects of their debtor's judicial restructuring. Most legal scholars and court precedents sustain that holders of credits assigned on a fiduciary basis fall under the category of "fiduciary owner of movable assets", as established by such $3^{\text {rd }}$ paragraph of article 49 of LRE and, therefore, are not subject to the debtor's judicial restructuring.

On the other hand, a small number of legal scholars and court precedents sustain that the $3^{\text {rd }}$ paragraph of article 49 of LRE contains no express reference to "holders of credits assigned on a fiduciary basis" and, given that such paragraph is an exception to the general rule that all creditors are subject to the debtor's judicial restructuring, its wording ought to be construed restrictively, for which reason such holders of the credits assigned on a fiduciary basis would be subject to the debtor's judicial restructuring.

Diverging views among legal scholars and court precedents on the matter bring about legal uncertainty as to the use of the fiduciary assignment of credits as a form of security. Financial institutions, on the one hand, are skeptical about the actual effectiveness of such form of security and that alone might impair the efficient assessment of the credit risk and the recovery of credits in the event of the debtor's insolvency. On the other hand, companies undergoing financial crisis question the feasibility of an effective restructuring, particularly if their major creditors are banks. 
For all those reasons, it is important to look into the fiduciary assignment of credits and critically analyze the solution adopted by the lawmakers vis-à-vis the principles of preserving companies in crises as introduced by the LRE. 
LISTA DE ABREVIATURAS, SIGLAS E DEFINIÇÕES.........................................4

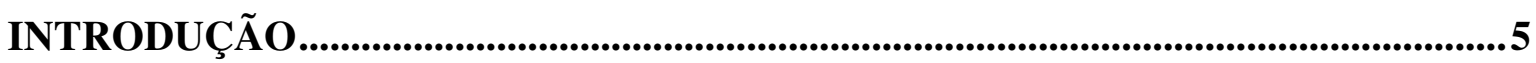

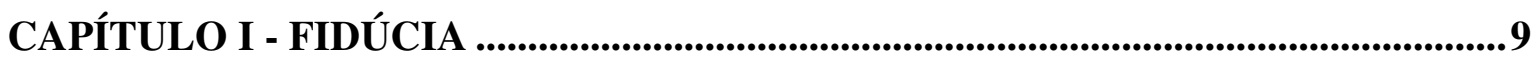

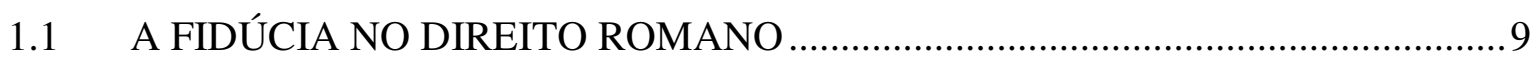

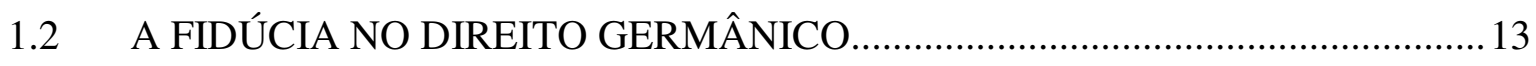

1.3 O TRUST NO DIREITO ANGLO-SAXÃO …...................................................... 15

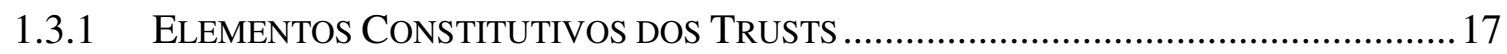

1.3.1.1 Elementos Objetivos ...................................................................... 17

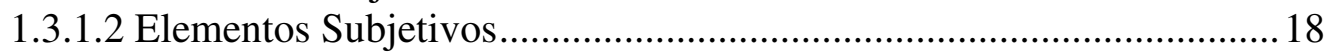

1.3.2 InVESTIDURA, RECUSA, RENÚNCIA E SUBSTITUIÇÃO DO TRUSTEE ...................... 19

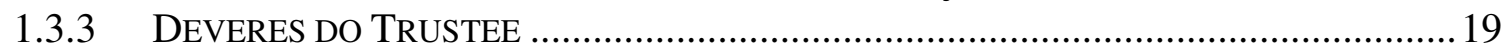

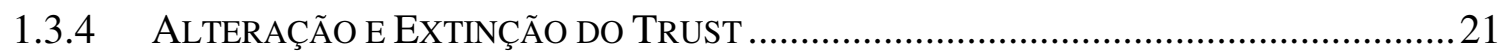

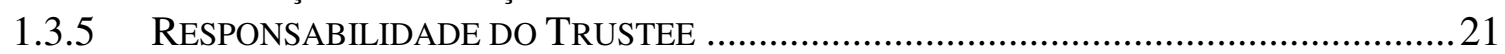

1.4 O FIDEICOMISSO LATINO-AMERICANO …...............................................23

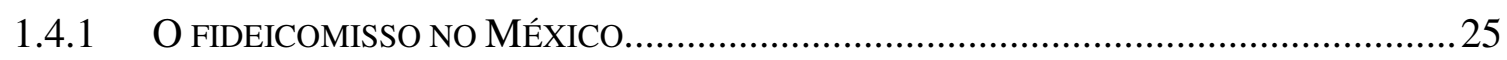

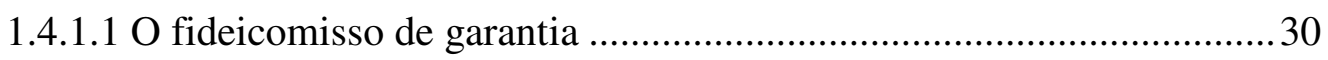

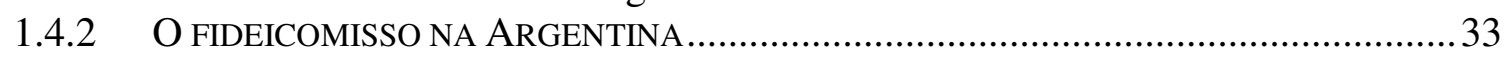

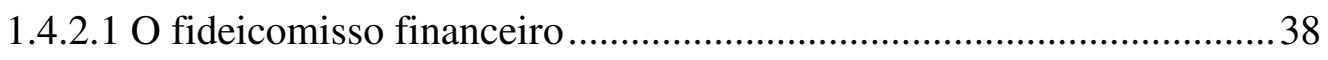

CAPÍTULO II - NEGÓCIO FIDUCIÁRIO...........................................................................40

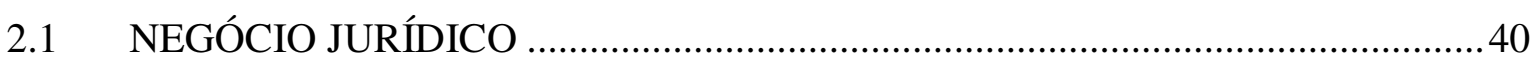

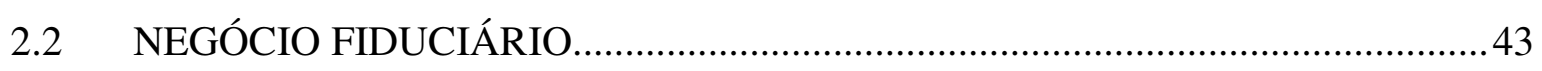

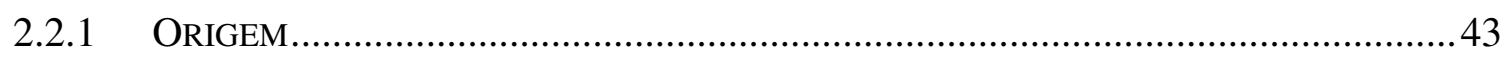

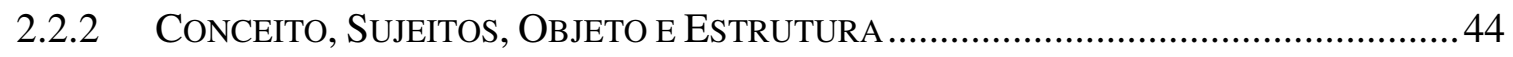

2.2.3 InCONGRUÊNCIA OU HETEROGENEIDADE ENTRE MEIO E FIM .............................51

2.2.4 A CAUSA NOS NEGÓCIOS FIDUCIÁRIOS ..................................................................53

2.2.5 RELAÇÕES INTERNAS E EXTERNAS NO NEGÓCIO FIDUCIÁRIO …............................54

2.3 DISTINÇÃO ENTRE NEGÓCIO FIDUCIÁRIO E NEGÓCIO INDIRETO.........56

2.4 DISTINÇÃO ENTRE NEGÓCIO FIDUCIÁRIO E NEGÓCIO SIMULADO........58

2.5 ESPÉCIES DE NEGÓCIO FIDUCIÁRIO NO BRASIL ..........................................59

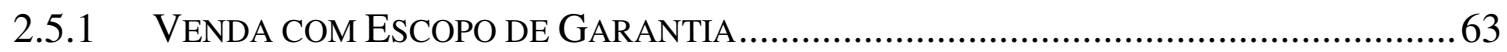

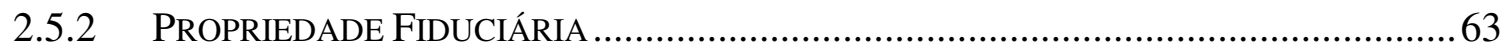

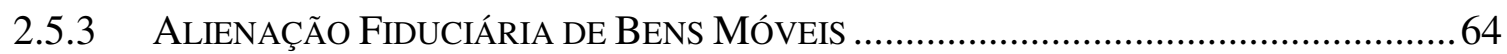

2.5.4 ALIENAÇÃO FIDUCIÁRIA DE BENS IMÓVEIS ....................................................69

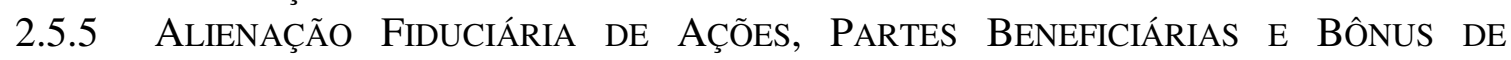

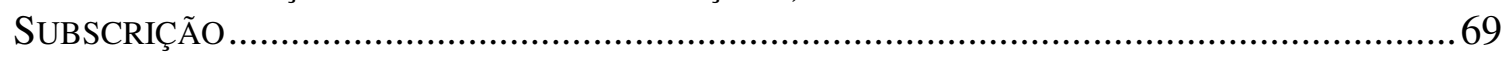

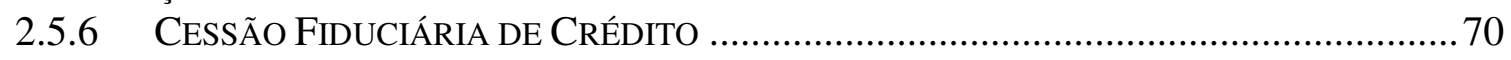

CAPÍTULO III - CESSÃO FIDUCIÁRIA .................................................................................71

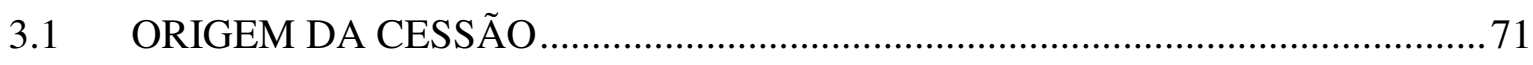

3.2 DISPOSIÇÕES GERAIS SOBRE A CESSÃO.................................................... 73 
3.2.1 Conceito, NATUREZA JuRÍDiCA, TIPOS E SuJEITOS ............................................ 73

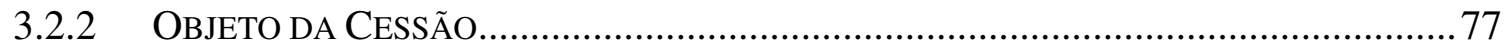

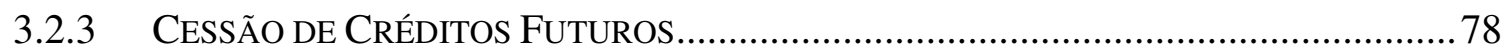

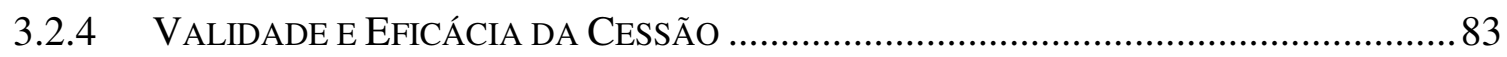

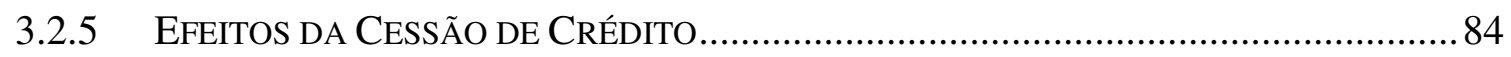

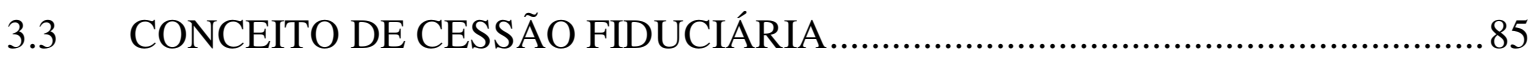

3.3.1 NATUREZA JuRÍdicA DA CESSÃo FiduCIÁRIA: DIREITO REAL OU

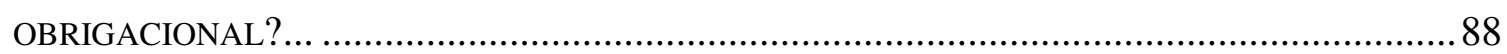

3.3.2 DistinÇÃo entre Cessão Fiduciária de CRÉdito EM Garantia E PENHOR dE

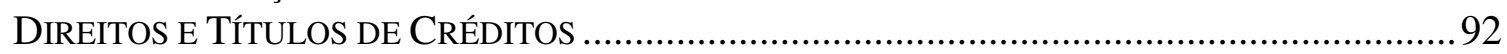

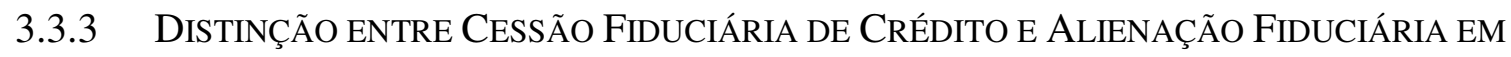

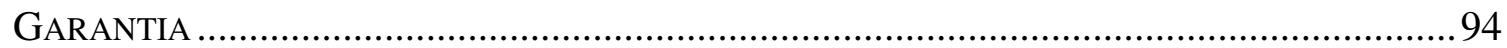

3.3.4 REgRAS GERAIS DA CESSÃo APLICÁvEIS À CESSÃo FiduCIÁRIA DE CRÉditos EM

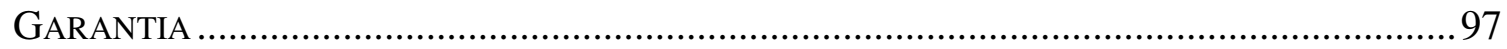

3.3.5 Regras do Penhor Aplicáveis À Cessão Fiduciária de Créditos em

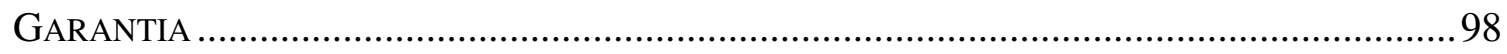

3.4 PRINCIPAIS ESPÉCIES DE CESSÃO FIDUCIÁRIA COM ESCOPO DE

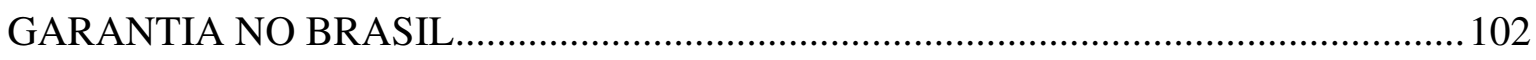

3.4.1 CESSÃo FidUCIÁRIA NO ÂMBITO DO MERCADO IMOBILIÁRIO ............................... 102

3.4.2 CESSÃo FidUCIÁRIA NO ÂMBITO do MERCAdo FinANCEIRO E DE CAPITAIS ..... 104

3.4.3 CESSÃo FiduCIÁRIA DE QUOTAS DE Fundo DE INVESTIMENTO PARA GARANTIA

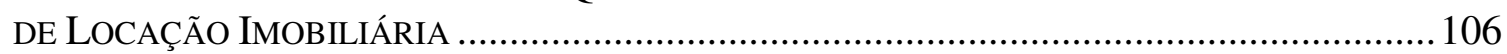

3.4.4 CESSÃO FIDUCIÁRIA NO ÂMBITO DAS CONCESSÕES PÚBLICAS ............................. 107

3.4.5 Cessẽo Fiduciária EM Garantia dE Direitos Creditórios DO

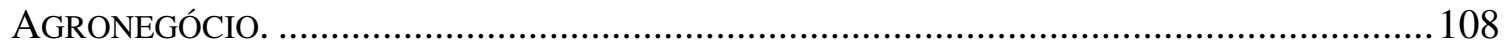

3.5 SUJEITOS DO CONTRATO DE CESSÃO FIDUCIÁRIA NO ÂMBITO DO

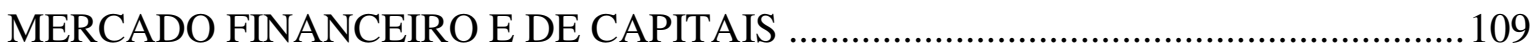

3.6 O OBJETO DO CONTRATO DE CESSÃO FIDUCIÁRIA NO ÂMBITO DO

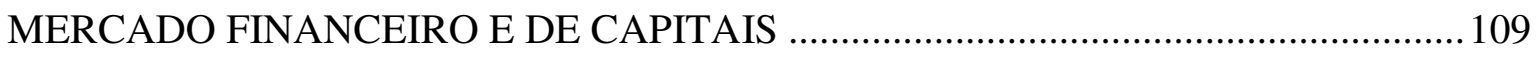

3.6.1 CESSÃO DE DiREITOS SOBRE COISAS MóveIS ..................................................... 109

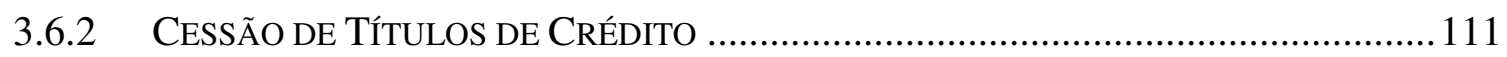

3.6.2.1 Principais Características dos Títulos de Crédito ............................... 112

3.6.2.2 Dos Títulos de Crédito como Bens Móveis ........................................ 115

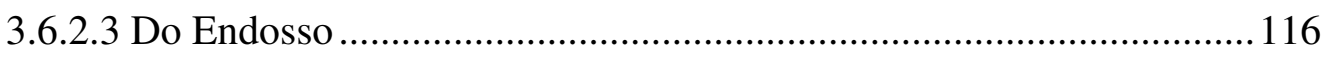

3.7 FORMALIZAÇÃO DO CONTRATO DE CESSÃO FIDUCIÁRIA..................... 120

3.8 DA MORA E DO INADIMPLEMENTO DO DEVEDOR-FIDUCIANTE .......... 124

3.9 SITUAÇÃO PATRIMONIAL DA CESSÃO FIDUCIÁRIA DE CRÉDITOS E DE TÍTULOS DE CRÉDITO .......................................................................................... 128

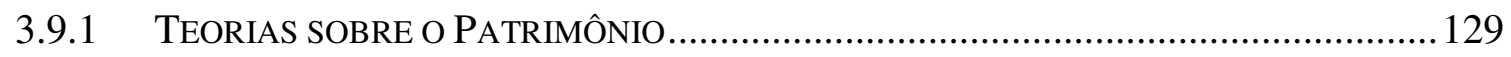

3.9.2 PATRIMÔNIO GERAL E ESPECIAL (OU SEPARADO) ............................................. 131

3.9.3 REgime PATRIMONIAL dos CRÉditos CEDIDOS FiduCIARIAMENTE: PATRIMÔNIO

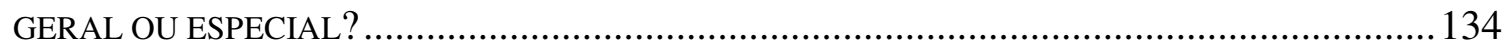

CAPÍTULO IV - TRATAMENTO DA CESSÃO FIDUCIÁRIA NAS HIPÓTESES DE RECUPERAÇÃO JUDICIAL E FALÊNCIA DO DEVEDOR-FIDUCIANTE .137 
4.1 ELABORAÇÃO LEGISLATIVA DO ATUAL ARTIGO 49, PARÁGRAFO $3^{\circ}$ DA

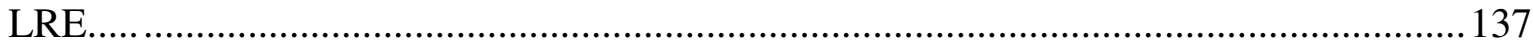

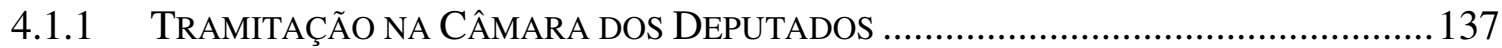

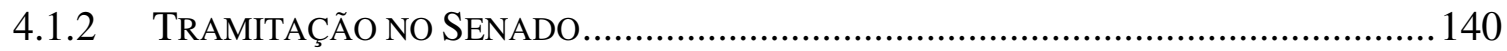

4.1.3 NOSSAS CONSIDERAÇÕES SOBRE O PROCESSO LEGISLATIVO .............................. 143

4.2 INTERPRETAÇÃO DO ARTIGO 49, PARÁGRAFO $3^{\circ}$ DA LEI DE

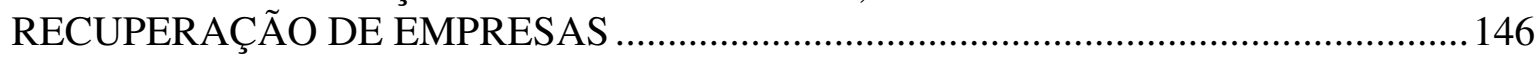

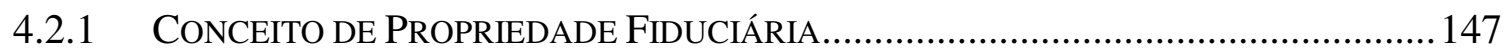

4.2.2 TITULARIDAdE FIDUCIÁRIA X PROPRIEDADE FIDUCIÁRIA................................... 149

4.3 POSIÇÃO DA DOUTRINA E JURISPRUDÊNCIA SOBRE O TRATAMENTO DA CESSÃO FIDUCIÁRIA NA RECUPERAÇÃO JUDICIAL DO DEVEDOR ........... 153

4.3.1 Corrente Que Defende a Não Sujeição dos Credores Garantidos POR CESSÃo Fiduciária AOS EFEITOS DA RECUPERAÇÃO JUdicial DO DEVEdoR-

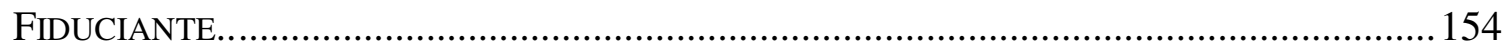

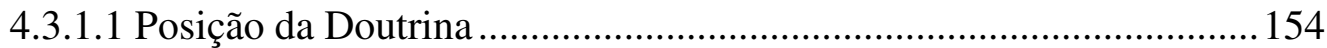

4.3.1.2 Posição da Jurisprudência ................................................................ 159

4.3.2 CORRENTE QUE DEFENDE A SUJEIÇÃO DOS CREDORES GARANTIDOS POR CESSÃO FIDUCIÁRIA AOS EFEITOS DA RECUPERAÇÃo JUdICIAL DO DEVEDOR-FIDUCIANTE ......... 166

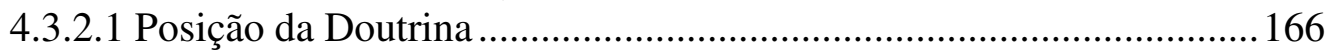

4.3.2.2 Posição da Jurisprudência ................................................................... 168

4.3.3 NOSSAS CONSIDERAÇÕES SOBRE O TEMA …................................................... 173

4.4 ANÁLISE CRÍTICA DA SOLUÇÃO ADOTADA PELO LEGISLADOR EM FACE DOS PRINCÍPIOS DA LEI DE RECUPERAÇÃO DE EMPRESAS .................... 177

4.5 POSIÇÃO DA DOUTRINA E JURISPRUDÊNCIA SOBRE O TRATAMENTO DA CESSÃO FIDUCIÁRIA NA FALÊNCIA DO DEVEDOR-FIDUCIANTE .............. 182

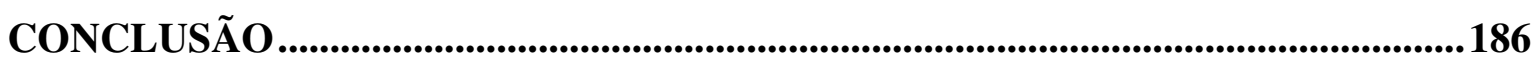

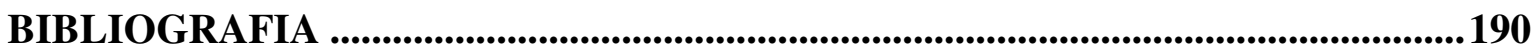




\section{LISTA DE ABREVIATURAS, SIGLAS E DEFINIÇÕES}

\begin{tabular}{|c|c|}
\hline $\mathrm{CC}$ & Código Civil \\
\hline CPC & Código de Processo Civil \\
\hline ed. & Edição \\
\hline FEBRABAN & Federação Brasileira de Bancos \\
\hline LGTOC & $\begin{array}{l}\text { Ley General de Títulos y } \\
\text { Operaciones de Crédito, de } \\
\text { 27.08.1932 (México) }\end{array}$ \\
\hline LIC & $\begin{array}{l}\text { Ley de Instituciones de Crédito de } \\
1924 \text { (México) }\end{array}$ \\
\hline LICC - Lei de Introdução ao Código Civil & \begin{tabular}{|llll} 
Decreto-lei & $\mathrm{n}^{\circ}$ & 4.657, & $\mathrm{de}$ \\
04.09 .1942 & & \\
\end{tabular} \\
\hline $\begin{array}{l}\text { Lei Uniforme - Lei Uniforme em Matéria de Letras de } \\
\text { Câmbio e Notas Promissórias }\end{array}$ & Decreto n$^{\circ} 57.663$, de 24.01 .1966 \\
\hline Lei de Mercado de Capitais & $\begin{array}{l}\text { Lei } \mathrm{n}^{\circ} 4.728, \text { de } 14.07 .1965 \mathrm{e} \\
\text { alterações posteriores }\end{array}$ \\
\hline Lei de Registros Públicos & $\begin{array}{l}\text { Lei } \mathrm{n}^{\circ} 6.015 \text {, de } 31.12 .1973 \mathrm{e} \\
\text { alterações posteriores }\end{array}$ \\
\hline Lei das Sociedades por Ações & 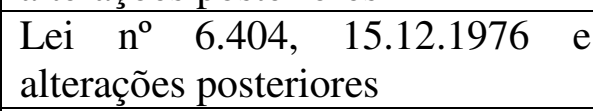 \\
\hline LSFI - Lei do Sistema de Financiamento Imobiliário & Lei n. ${ }^{\circ} 9.514$, de 20.11 .1997 \\
\hline $\begin{array}{l}\text { LRE - Lei de Recuperação Judicial, Extrajudicial e de } \\
\text { Falência das Empresas }\end{array}$ & Lei $\mathrm{n}^{\circ}$ 11.101, de 09.02.2005 \\
\hline PL & Projeto de Lei \\
\hline p. & Página \\
\hline pp. & Páginas \\
\hline ss. & Seguintes \\
\hline TJES & $\begin{array}{l}\text { Tribunal de Justiça do Estado do } \\
\text { Espírito Santo }\end{array}$ \\
\hline TJGO & \begin{tabular}{|l}
$\begin{array}{l}\text { Tribunal de Justiça do Estado de } \\
\text { Goiás }\end{array}$ \\
\end{tabular} \\
\hline TJMG & $\begin{array}{l}\text { Tribunal de Justiça do Estado de } \\
\text { Minas Gerais }\end{array}$ \\
\hline TJMT & $\begin{array}{l}\text { Tribunal de Justiça do Estado de } \\
\text { Mato Grosso }\end{array}$ \\
\hline TJPR & $\begin{array}{l}\text { Tribunal de Justiça do Estado do } \\
\text { Paraná }\end{array}$ \\
\hline TJSP & $\begin{array}{l}\text { Tribunal de Justiça do Estado de } \\
\text { São Paulo }\end{array}$ \\
\hline TJRJ & $\begin{array}{l}\text { Tribunal de Justiça do Estado do } \\
\text { Rio de Janeiro }\end{array}$ \\
\hline $\mathrm{v}$. & Volume(s) \\
\hline$\S$ & Parágrafo \\
\hline
\end{tabular}




\section{INTRODUÇÃO}

A cessão fiduciária de títulos de crédito e/ou de direitos creditórios, também conhecida no mercado financeiro e de capitais como "trava bancária", passou a ser largamente utilizada pelas instituições financeiras como garantia de seus empréstimos a partir da edição da Lei $n^{\circ}$ 10.931, de 02.08.2004, que inseriu o artigo 66-B na Lei n. ${ }^{\circ} 4.728$, de 14.07.1965 ("Lei de Mercado de Capitais")'

Antes do advento da cessão fiduciária de créditos e/ou títulos de crédito, as instituições financeiras utilizavam o penhor de direitos creditórios e/ou de títulos de crédito como garantia de suas operações financeiras. Apesar de o penhor ser uma garantia tradicionalmente utilizada e com jurisprudência consolidada, ele apresenta dois inconvenientes: o primeiro deles é que sua eficácia depende da notificação do devedor; o segundo é que o penhor está sujeito à recuperação judicial e à falência do devedor pignoratício, na classe dos créditos com garantia real.

A cessão fiduciária de créditos apresentou-se como uma garantia mais vantajosa, primeiro porque sua eficácia não depende da notificação do devedor e, depois, porque parte da doutrina e da jurisprudência tem defendido que a cessão fiduciária de créditos não está sujeita aos efeitos da recuperação judicial do devedor fiduciante, por interpretação do artigo 49, parágrafo $3^{\circ}$ da Lei n. ${ }^{\circ}$ 11.101, de 09.02.2005 (“LRE - Lei de Recuperação Judicial, Extrajudicial e de Falência das Empresas").

Na cessão fiduciária de créditos e/ou títulos de crédito, opera-se a transmissão fiduciária da titularidade dos créditos ao credor-fiduciário (cessionário) até o pagamento integral da dívida pelo devedor-fiduciante (cedente). Ao credor-fiduciário compete o direito de receber diretamente dos devedores do devedor-fiduciante os créditos cedidos

\footnotetext{
${ }^{1}$ Parágrafo $3^{\circ}$ do Art. 66-B: "É admitida a alienação fiduciária de coisa fungível e a cessão fiduciária de direitos sobre coisas móveis, bem como de títulos de crédito, hipóteses em que, salvo disposição em contrário, a posse direta e indireta do bem objeto da propriedade fiduciária ou do título representativo do direito ou do crédito é atribuído ao credor, que, em caso de inadimplemento ou mora da obrigação garantida, poderá vender a terceiros o bem objeto da propriedade fiduciária independente de leilão, hasta pública ou qualquer outra medida judicial ou extrajudicial, devendo aplicar o preço da venda no pagamento do seu crédito e das despesas decorrentes da realização da garantia, entregando ao devedor o saldo, se houver, acompanhado do demonstrativo da operação realizada." (grifo nosso)
} 
fiduciariamente e a utilizar as importâncias recebidas para amortizar a dívida contraída pelo devedor-fiduciante, responsabilizando-se o credor-fiduciário perante o devedorfiduciante pelo que receber além do que este lhe devia, nos termos do inciso IV do parágrafo primeiro do artigo 19 da Lei n. ${ }^{\circ}$ 9.514, de 20.11.1997 (“LSFI - Lei do Sistema de Financiamento Imobiliário").

Por outro lado, se as importâncias recebidas não bastarem para o pagamento integral da dívida e seus encargos, bem como das despesas de cobrança e administração daqueles créditos, o devedor-fiduciante continuará obrigado a resgatar o saldo remanescente nas condições convencionadas entre as partes, nos termos do parágrafo segundo do artigo 19 da LSFI.

Como se vê, os créditos cedidos fiduciariamente passam a ser de titularidade do credor-fiduciário, sendo esta titularidade condicionada e limitada ao escopo para a qual foi constituída. Em razão da transferência de titularidade dos créditos cedidos fiduciariamente, resta analisar o tratamento a ser dado aos referidos créditos nas hipóteses de recuperação judicial e/ou falência do devedor-fiduciante.

\subsection{Hipótese de Recuperação Judicial do Devedor-Fiduciante}

A questão a ser analisada é se o crédito cedido fiduciariamente estaria ou não sujeito aos efeitos da recuperação judicial do devedor-fiduciante.

Nos termos da LRE, a regra geral é que estão sujeitos à recuperação judicial todos os créditos existentes até a data do pedido, ainda que não vencidos. Todavia, os parágrafos $3^{\circ}$ e $4^{\circ}$ do artigo 49 da LRE regulam os créditos que estão excluídos da recuperação judicial do devedor:

“Art. 49. Estão sujeitos à recuperação judicial todos os créditos existentes na data do pedido, ainda que não vencidos.

...

$\S 3^{\circ}$ Tratando-se de credor titular da posição de proprietário fiduciário de bens móveis ou imóveis, de arrendador mercantil, de proprietário ou promitente vendedor de imóvel cujos respectivos contratos contenham cláusula de irrevogabilidade ou irretratabilidade, inclusive em incorporações imobiliárias, ou 
de proprietário em contrato de venda com reserva de domínio, seu crédito não se submeterá aos efeitos da recuperação judicial e prevalecerão os direitos de propriedade sobre a coisa $\boldsymbol{e}$ as condições contratuais, observada a legislação respectiva, não se permitindo, contudo, durante o prazo de suspensão a que se refere o $\$ 4^{o}$ do art. $6^{\circ}$ desta Lei, a venda ou a retirada do estabelecimento do devedor dos bens de capital essenciais a sua atividade empresarial." (grifo nosso)

$\S 4^{\circ}$ Não se sujeitará aos efeitos da recuperação judicial a importância a que se refere o inciso II do artigo 86 desta Lei ${ }^{2}$."

Da leitura do parágrafo $3^{\circ}$ do artigo 49 da LRE temos que o crédito detido pelo credor titular da posição de proprietário fiduciário de bens móveis ou imóveis não está sujeito aos efeitos da recuperação judicial do devedor, sendo mantidas inalteradas as condições contratuais originalmente acordadas.

Pretendemos analisar a natureza jurídica do instituto da cessão fiduciária de créditos e títulos de crédito prevista no artigo 66-B da Lei de Mercado de Capitais, assim como a posição da doutrina e jurisprudência sobre o tema, para verificar se os créditos e/ou títulos de crédito cedidos fiduciariamente estariam ou não sujeitos aos efeitos da recuperação judicial do devedor-cedido, nos termos do parágrafo $3^{\circ}$ do artigo 49 da LRE.

\subsection{Hipótese de Falência do Devedor-Fiduciante}

No presente trabalho também abordaremos o tratamento a ser dado aos créditos e/ou títulos de crédito cedidos fiduciariamente na hipótese de falência do devedorfiduciante.

\subsection{Razão de Ordem e de Método}

O presente trabalho encontra-se dividido em 4 (quatro) capítulos. No primeiro capítulo abordaremos a evolução histórica do instituto da fidúcia romana e germânica, passando pela análise do trust anglo-saxão e do fideicomisso adotado no México e na Argentina.

\footnotetext{
${ }^{2}$ O inciso II do artigo 86 da LRE dispõe sobre a importância entregue ao devedor, em moeda corrente nacional, decorrente de adiantamento de contrato de câmbio para exportação, na forma do art. $75, \S \S 3^{\circ}$ e $4^{\circ}$ da Lei n. ${ }^{\circ} 4.728$, de 14.07.1965, desde que o prazo total da operação, inclusive eventuais prorrogações, não exceda o previsto nas normas específicas da autoridade competente.
} 
No segundo capítulo abordaremos o negócio fiduciário, sua origem, conceito, principais características e espécies, bem como faremos as distinções entre o negócio fiduciário e o negócio indireto e o negócio simulado.

No terceiro capítulo faremos um estudo aprofundado da cessão fiduciária de crédito e títulos de créditos, passando, primeiramente, pelo estudo geral da cessão, para então abordar o conceito, natureza jurídica, espécies e principais características da cessão fiduciária de créditos e/ou títulos de crédito, fazendo as necessárias distinções entre figuras afins tais como: penhor de direitos creditórios e alienação fiduciária em garantia.

No quarto e último capítulo discutiremos o tratamento a ser dado aos créditos cedidos fiduciariamente na hipótese de recuperação judicial e falência do devedorfiduciante, tomando-se por base a análise do processo legislativo do atual artigo 49, parágrafo $3^{\circ}$ da LRE, a análise do conceito de "proprietário fiduciário de bens móveis" contido no referido artigo, e a posição da doutrina e da jurisprudência atual sobre o tema. Por fim, faremos também uma análise crítica da solução adotada pelo legislador em face dos princípios da LRE. 


\section{CAPÍTULO I - FIDÚCIA}

A palavra fidúcia deriva da palavra latina fiducia, ae e significa confiança, lealdade e fidelidade, tendo tido primitivamente o significado de venda simulada ${ }^{3}$. A fidúcia tem como um de seus pressupostos a boa-fé e a confiança depositada pelo fiduciante no fiduciário, ao transmitir-lhe a propriedade de uma coisa, para fins de administração ou em garantia real do negócio jurídico existente entre eles.

Por meio da fidúcia, tornou-se possível a realização de negócios jurídicos que não encontravam soluções jurídicas adequadas nas legislações da época, preenchendo, portanto, as lacunas de tais sistemas jurídicos.

Como bem salienta Paulo Restiffe $\mathrm{Neto}^{4}$, a fidúcia, desde o seu aparecimento histórico, serviu de meio adequado ao atendimento de finalidades queridas pelas partes, que não encontravam no sistema jurídico vigente o instrumental adequado.

\subsection{A fidúcia no direito romano}

É difícil precisar quando houve o aparecimento da fidúcia no direito romano, pois como bem observa Otto de Souza Lima ${ }^{5}$, a fidúcia foi, de início, uma convenção, ligada a um ato solene, constituindo uma cláusula secreta, que, por isso mesmo, em sua origem, foi desprovida de qualquer sanção legal. Nestas condições, difícil, ou mesmo impossível, será determinar-lhe, no tempo, a origem.

Biondo Biondi $^{6}$ esclarece que inicialmente a fidúcia importava apenas uma obrigação moral, dependendo sua execução da confiança depositada no acipiente. Sucessivamente, teve sanção jurídica, com a introdução da actio fiduciae, fundada no pactum fiduciae, concedido ao fiduciante contra o fiduciário.

\footnotetext{
3 Álvaro Villaça Azevedo (Prisão Civil por Dívida, p. 80) esclarece que a palavra fidúcia, ae, deriva de fides, $e i$, que se formou do radical do verbo semidepoente, da terceira conjugação latina, fido, is, fisus sum, fidere.

${ }^{4}$ Garantia Fiduciária, p. 5

${ }_{6}^{5}$ Negócio Fiduciário, p. 11.

${ }^{6}$ Istituzioni di Diritto Romano, p. 142 e 143.
} 
Otto de Souza Lima ${ }^{7}$ aponta o primeiro traço evidente da fidúcia na Lei das XII Tábuas. Já os compiladores do Digesto procuraram apagar todos os vestígios do instituto. Observa o referido autor que as notícias que nos chegaram sobre a fidúcia romana o foram através de autores não jurídicos, como Cícero, Boécio e Isidoro de Sevilha, e ainda, de obras jurídicas como as Institutas de Gaio, as Sentenças de Paulo, a Collatio, Fragmentos do Vaticano e de uma Constituição do Código Teodosiano. Além dessas fontes, há também a chamada Fórmula Bética, que é uma inscrição gravada em uma Tábua de Bronze descoberta em 1867, na Andaluzia, perto da foz do rio Guadalquevir, que, em latim, chamava-se Baetis, de onde lhe veio o nome. Nesta Tábua de Bronze havia um modelo de alienação fiduciária com escopo de penhor. ${ }^{8}$ Importante mencionar as Tábuas de Pompéia, tábuas de cera descobertas em 1887, que continham a documentação de um negócio fiduciário concreto, com escopo de garantia real, que teria sido realizado em 61 d.C. ${ }^{9}$

Renè Jacquelin ${ }^{10}$ aponta também a Lex Julia, ou Julia Municipalis, também conhecida por Tabula Heracleensis, tratando-se de uma lei latina gravada sobre uma das faces de duas tábuas de bronze, sendo que a outra face continha um texto grego que fazia referência expressa ao judicio fiduciae.

A fidúcia é definida pela doutrina como uma convenção pela qual uma das partes (fiduciário), recebendo da outra (fiduciante) uma coisa, na forma de mancipatio ou de in iure cessio, assume a obrigação de usá-la para um fim determinado e a restituí-la ao cabo desse fim. ${ }^{11}$

Ensina Álvaro Villaça Azevedo ${ }^{12}$ que a fidúcia antecedeu, historicamente, ao penhor (pignus), sendo o principal escopo daquela o de conferir ao credor a máxima garantia, pois que importava a transferência da propriedade da coisa ou do direito, pelo fiduciante ao fiduciário, na forma da mancipatio ou da in iure cessio, com a obrigação de utilizar esse objeto para uma determinada finalidade, restituindo-se-o, a final, com o

\footnotetext{
${ }^{7}$ Ibid., p. 17.

${ }^{8}$ Carlo Longo, Corso di Diritto Romano - La fiducia, p. 10.

${ }^{9}$ Ibid., p. 13.

${ }^{10}$ Renè Jacquelin. De La fiducie, p. 57.

${ }^{11}$ Pietro Bonfante, Istituzioni di Diritto Romano, p. 413; Giuseppe Messina, Scritti Giuridici, v.1, p. 107; Otto de Souza Lima, Negócio Fiduciário, p. 44; e Melhim Namem Chalhub, Negócio Fiduciário, p. 12.

${ }_{12}$ Alienação Fiduciária de Garantia em Bem Móvel e Imóvel. In: Revista da Faculdade de Direito da Fundação Armando Álvares Penteado, ano 1, no 1 - 2002, p. 62.
} 
advento do termo ou o implemento da condição. Esclareça-se que o não cumprimento dessa obrigação de restituir, por parte do fiduciário, resolvia-se em perdas e danos, pois o fiduciante, quando transmitia o bem fiduciado, perdia sua propriedade, não tendo assim, possibilidade de exercitar ação reivindicatória para fazê-lo retornar a seu patrimônio. A transmissão em garantia era do próprio domínio da coisa. No penhor, ao contrário, o devedor transmitia a posse da coisa. O credor, não se tornando proprietário dela, não poderia aliená-la, ficando como simples possuidor, com os meios de proteção possessória, até que recebesse seu crédito.

Da análise dos conceitos de fidúcia acima, nota-se que a fidúcia tinha, portanto, dois elementos fundamentais, sendo um deles de direito real, caracterizado pela transferência da propriedade do bem, seja pela mancipatio ou pela in iure cessio, e outro elemento de direito obrigacional fundado no pactum fiduciae, que importava na obrigação de restituição do bem a quem o transferiu, após o cumprimento da finalidade da transferência. Importante notar que a restituição do bem operava-se da mesma forma pela qual o bem havia sido transferido (remancipatio ou in iure cessio).

A mancipatio e a in iure cessio eram duas formas solenes e formais de transferência da propriedade, caracterizando-se a mancipatio pela transferência da propriedade independentemente da causa da alienação. Thomas Marky ${ }^{13}$ salienta que a mancipatio era no início uma compra e venda real, adquirindo um caráter abstrato no período clássico. Praticando-se a mancipatio, transferia-se a propriedade de um bem, independentemente da natureza ou validade do ato jurídico em que se fundava, sendo, por exemplo, válida a mancipatio de um escravo, embora a venda em que ela se baseava fosse viciada por dolo praticado pelo comprador. A in iure cessio era originariamente um processo simulado, passando, no período clássico, a ser um ato jurídico abstrato. Serve para transferir a propriedade não só da res mancipi ${ }^{14}$, mas também da res nec mancipi $i^{15}$.

\footnotetext{
13 Curso Elementar de Direito Romano, p. 80.

${ }^{14}$ São "res mancipi" os imóveis, servidões rústicas, escravos, animais de tiro e carga (Alexandre Correia e Gaetano Sciascia, Manual de Direito Romano, p. 57).

${ }^{15}$ Segundo Pietro Bonfante (Istituzioni di Diritto Romano, $3^{\mathrm{a}}$ ed., p. 246), a res nec mancipi era tudo aquilo que não era considerado res mancipi, tendo Justiniano abolido a diferença entre res mancipi e res nec mancipi.
} 
A in iure cessio operava-se perante um magistrado, tendo a forma exterior de um legis actio, de uma reivindicação fictícia, consubstanciada no emprego figurativo de uma forma processual para operar, de modo solene, a transferência voluntária do domínio. ${ }^{16}$

O pactum fiduciae era aquele pelo qual o fiduciário assumia a obrigação de restituir, ou segundo a linguagem romana, remancipare, a res a ele transmitida. É o elemento obrigacional do negócio, do qual deriva a obrigação do fiduciário, afirmando, mesmo, alguns autores que ele é o centro de gravidade da operação fiduciária. ${ }^{17}$

Existiam duas espécies de fidúcia no direito romano, a fiducia cum amico e a fiducia cum creditore. A fiducia cum amico caracterizava-se pela transferência de um bem de uma pessoa a um amigo seu, que deveria usá-lo como se seu fosse até que houvesse o pedido de restituição do referido bem por parte de quem o transferiu.

Ensina Biondo Biondi ${ }^{18}$ que tinha-se a fiducia cum amico toda vez que uma pessoa transferisse a uma outra o domínio de uma coisa, mas somente com o escopo de custódia ou guarda ou de gozo gratuito temporário, sempre com o pacto de transferência do domínio ao alienante sob requisição do mesmo ou sob outro pacto.

A fiducia cum creditore caracterizava-se pela transferência de um bem do devedor ao credor, como garantia de pagamento de uma dívida objeto de um contrato celebrado entre devedor e credor. $\mathrm{O}$ credor, por sua vez, era obrigado a restituir o referido bem ao devedor após o integral pagamento da dívida pelo devedor. Ressalte-se que a transferência da propriedade do bem do fiduciante ao fiduciário era feita de forma plena e absoluta. Desta forma, o fiduciário era investido de todos os poderes necessários para usar o bem, protegê-lo contra turbações e reivindicá-lo de terceiros. Além disso, tinha o fiduciante o direito aos frutos produzidos pela coisa e também às benfeitorias nela realizadas.

\footnotetext{
${ }^{16}$ Otto de Souza Lima, Negócio jurídico, p. 65.

${ }^{17}$ Ibid., p. 75.

${ }^{18}$ Corso di Istituzioni di Diritto Romano, v. I, p. 197.
} 
Biondo Biondi ${ }^{19}$ observa que tinha-se a fiducia cum creditore toda vez que o devedor ou um terceiro transferia ao credor a propriedade de uma coisa, mas simplesmente com o escopo de garantia, baseado na confiança no credor que este transferisse a propriedade da coisa ao alienante quando o débito fosse pago; isso constituía um pactum fiduciae que se adicionava ao mancipatio; desde o princípio tratava-se de uma obrigação de consciência, sucessivamente tornou-se uma obrigação jurídica, e o alienante teve a actio fiduciae para obrigar o credor à transferência do domínio.

A fiducia cum creditore apresentava alguns inconvenientes tanto para o devedor quanto para o credor, como bem ressalta José Carlos Moreira Alves ${ }^{20}$ :

"Para o devedor, porque ele tinha de transferir a propriedade da coisa ao credor, não podendo fruí -la enquanto não se extinguisse o débito; além disso, às vezes, o devedor era obrigado a transferir a propriedade de coisa de valor bem superior ao do débito, não podendo, portanto, utilizar-se dela para a obtenção de outros créditos; e enfim, o devedor, para reaver a coisa, ficava, primitivamente, na dependência exclusiva da vontade do credor, pois não dispunha contra este de uma actio para compeli-lo à restituição da res e, mesmo mais tarde, quando surgiu a actio fiduciae, era ela uma ação pessoal contra o credor, razão porque, se este alienasse a coisa a terceiro, em vez de restituí-la, o devedor, pela actio fiduciae, podia obter apenas indenização pelo não cumprimento do pacto de restituição da coisa, e não o desfazimento da venda ao terceiro. Por outro lado, para o credor tinha a fiducia cum creditore o inconveniente de permitir ao devedor, caso reintegrasse ele na posse da res, a recuperação da propriedade sobre ela, ao fim apenas de um ano, independentemente de justo título e de boa-fé, mediante modalidade especial de usucapião: a usureceptio."

A fidúcia entrou em desuso em razão do desaparecimento dos dois modos formais de transferência da propriedade (a mancipatio e a in iure cessio), tendo desaparecido por completo da legislação de Justiniano.

\subsection{A fidúcia no direito germânico}

Os antecedentes da fidúcia no direito germânico baseiam-se em três institutos, a saber: o penhor imobiliário, o manusfidelis e o Salman ou treuhand.

${ }^{19}$ Corso di Istituzioni di Diritto Romano, v. I, p. 197.

${ }^{20}$ Da Fidúcia Romana à Alienação Fiduciária em Garantia no Direito Brasileiro. In: Youssef Said Cahali (Coord.). Contratos Nominados: Doutrina e Jurisprudência, p. 24. 
A fidúcia no direito germânico tem traços que se assemelham à fidúcia do direito romano, mas dela se distingue em razão da natureza e dos limites dos poderes atribuídos ao fiduciário (treuhander) sobre a coisa objeto da fidúcia. Na fidúcia do tipo germânico a transmissão do bem se dá sob condição resolutiva, estabelecendo-se uma propriedade limitada em favor do fiduciário até o adimplemento da dívida garantida pelo referido bem.

Giuseppe Messina ${ }^{21}$ indica que a fidúcia no direito germânico era uma forma de penhor mediante o qual o devedor transmitia a posse da coisa a fim de que o credor dela utilizasse até a extinção da dívida.

Desta forma, a propriedade continuava a pertencer ao devedor, que só a perderia se houvesse uma cláusula especial estabelecendo, no próprio ato constitutivo, essa perda em caso de não pagamento do débito. Sendo o fiduciante o legítimo proprietário do bem, ele tinha o direito de reivindicar o bem contra o fiduciário e contra qualquer terceiro que o detivesse. $^{22}$

Segundo Messina ${ }^{23}$, a transferência da propriedade era feita por meio de uma carta venditionis, que era vinculada a um pacto de restituição, denominado contracarta, por meio do qual o credor prometia restituir o bem em caso de pagamento do débito.

Como bem salientam Kiper e Lisoprawski ${ }^{24}$, a estrutura da fidúcia do tipo germânica conduz a uma divisão de direitos, que converte o fiduciário em proprietário ou credor formal ou legal, ainda que a propriedade ou o direito de crédito material correspondam ao fiduciante. Divide-se o direito de propriedade em domínio legítimo e domínio material. Esta concepção, do tipo feudal, passou ao direito inglês, e mas precisamente ao trust.

\footnotetext{
${ }^{21}$ Scritti Giuridici, v.1, p. 147/148 ("l'affiduciatum del diritto langobardo era uma forma de pegno mediante la quale il debitore trasmetava il possesso dela coisa affinchè questi ne godesse ed usasse fino all'estinzione de debito.")

${ }^{22}$ Otto de Souza Lima, Negócio Fiduciário. Tese para concurso a cátedra de Direito Civil, da Faculdade de Direito da Universidade de São Paulo, 1959.p. 124.

${ }^{23}$ Scritti Giuridici, p. 139

${ }^{24}$ Claudio Marcelo Kiper e Silvio V. Lisoprawski, Tratado de fideicomisso, p. 3. (Tradução livre de: "la estructura de la fiducia de tipo germánico conduce a una división de derechos que convierte al fiduciario en propietario o acreedor formal o legal, mientras que la propiedad o el derecho de crédito material corresponden al fiduciante. Se fracciona el derecho de propiedad en dominium legitimum y dominium material. Esta concepción, de tipo feudal, pasó al derecho inglés, y más precisamente al trust.”)
} 
Na fidúcia do tipo germânico, portanto, o fiduciário era o proprietário formal, enquanto o fiduciante era o proprietário legal. A fidúcia no direito germânico distingue-se da fidúcia no direito romano, pois nesta última o fiduciário recebia um ilimitado poder jurídico sobre a coisa, sendo certo que, se dispusesse da coisa arbitrariamente, sem observância do pactum fiduciae, não se dava ao fiduciante senão o direito de haver a reparação das perdas e danos. Já no direito germânico o poder jurídico do fiduciário era limitado pelo caráter resolutório da propriedade que recebia, de modo que eventual alienação arbitrária por parte do fiduciário era considerada ineficaz, daí porque o fiduciante retomava a propriedade da coisa por efeito da condição resolutiva ${ }^{25}$.

\section{3 $O$ trust no direito anglo-saxão}

O trust teve sua origem na Inglaterra pelos uses, cuja aparição remonta à Idade Média como meio para evitar os confiscos em tempos de guerra e de perseguições políticas que se abatiam sobre os vencidos, assim como para evitar o pagamento de tributos feudais e o rigor das leis que proibiam que as congregações religiosas pudessem ser proprietárias de bens imóveis.

Harold Hanbury anota que há muitas definições de trust, mas nenhuma completamente satisfatória. Ele também observa que muitas vezes o trust confunde-se com o mandato, devendo ser analisadas as circunstâncias de cada caso. ${ }^{26}$

O termo trust é empregado por tribunais e advogados em diversos sentidos. Às vezes engloba vários negócios fiduciários e não somente o trust em sentido estrito. Em sentido estrito, aplica-se o termo trust para o negócio fiduciário específico que surgiu na Inglaterra, com a separação entre a Corte de Justiça (Court of Law) e a de equidade (Court of Equity). ${ }^{27}$

\footnotetext{
${ }^{25}$ Giuseppe Messina, Scritti Giuridici, v.1, p. 159.

${ }^{26}$ Modern Equity, $3^{\mathrm{a}}$ Ed., Stevens \& Sons, Limited. Londres, 1943, p. 110

${ }^{27}$ Austin Scott, The Law of Trusts, p. 34 e 35.
} 
Define-se o trust como sendo uma relação jurídica pela qual uma pessoa (feoffee to use) era investida, segundo a common law, de poder jurídico cujo exercício deveria beneficiar economicamente outra pessoa (cestui que use). Com efeito, configura-se o trust pela entrega de certos bens a uma pessoa, para que deles faça uso conforme determinado encargo que lhe tenha sido cometido, repousando esse conceito na confiança depositada naquele que recebe os bens. Aquele que entrega os bens e, por conseqüência, institui o trust, é denominado settlor (instituidor); o settlor transmite, efetivamente, a propriedade sobre os bens. Aquele que recebe os bens, e assume a obrigação de administrá-los, denomina-se trustee (aquele em quem se confia). Aquele em favor de quem o trust é instituído denomina-se cestui que trust (aquele que confia). ${ }^{28}$

Como bem explica Eduardo Salomão Neto, os trusts podem ser divididos em privados e relativos a propósitos. Os trusts privados são aqueles que visam ao atendimento de beneficiários finais individualizados e subdividem-se em: (i) trust expresso: aquele que é expressa e intencionalmente declarado pelo instituidor, através da manifestação de sua vontade e do cumprimento de certas formalidades; (ii) trust interpretativo: é aquele criado em virtude de considerações eqüitativas, em benefício de partes que se veriam de outra forma privadas de amparo ou remédio em caso de violações de seus direitos. Existirá um trust interpretativo sempre que, por razões de eqüidade, determinarem os tribunais que uma pessoa deva gerir seu patrimônio ou parte dele em benefício de terceiro; e (iii) trust resultante: é aquele em que os beneficiários derivados do trust retornam total ou parcialmente para o instituidor (ex. o instituidor não distribuiu a totalidade dos direitos resultantes de um trust entre os beneficiários, caso em que retorna ao instituidor o direito proporcional à parte sem titular). Já os trusts instituídos em vista de propósitos ou finalidades genéricas, nos casos em que são aceitos, são denominados de trusts relativos a propósitos ("purpose trusts"), que se subdividem em trusts que visam a finalidades caritativas ou ligadas ao bem público ("charitable purpose trusts") e aqueles que, sem preencher tais requisitos, encontram reconhecimento jurisprudencial, em caráter de exceção. $^{29}$

\footnotetext{
${ }^{28}$ Melhim Namem Chalhub, Negócio fiduciário, $4^{\mathrm{a}}$ ed., p. 17.

${ }^{29}$ O trust e o direito brasileiro, pp. 21-24. Neste sentido, Austin Scott (The Law of Trusts, p. 34 e 35) ensina que quanto à forma, os trusts dividem-se em: trusts expressos, trusts de resultado e trusts interpretativos. Note-se, contudo, que estão agrupados três modelos jurídicos cujas diferenças são mais relevantes do que as semelhanças. O trust expresso, por exemplo, difere tanto do trust interpretativo, na forma como é empregado
} 
O trust implica a segregação de um patrimônio, e a conseqüente criação de um patrimônio de afetação, que não se confunde com o patrimônio do instituidor (settlor), nem com o do trustee. Na hipótese de insolvência do trustee, os bens objetos do trust não integrarão sua massa concursal, por estarem submetidos a uma afetação que os vincula à finalidade definida no contrato. ${ }^{30}$

O trust difere-se precipuamente da fidúcia romana e da fidúcia no direito germânico em razão da dicotomia da propriedade, pela qual podem coexistir sobre um mesmo bem dois direitos de propriedade (legal property, do trustee, e a equitable property, do beneficiário). Em razão da dicotomia da propriedade, noção peculiar do direito inglês, e em função do sistema processual de proteção do beneficiário, mediante atuação do Judiciário no controle e fiscalização da atividade do trustee, este sistema proporciona o mais alto grau de eficácia na implementação dos trusts e na defesa dos interesses do beneficiário. ${ }^{31}$

\subsubsection{Elementos Constitutivos dos Trusts}

Os trusts são constituídos por elementos objetivos e subjetivos.

\subsubsection{Elementos Objetivos}

São elementos objetivos do trust: a intenção, a transmissão dos bens ou direitos para o trustee e o objeto (res).

A intenção do instituidor do trust é elemento condicionante da existência de todos os trusts relativos a propósitos e dos trusts privados expressos. Já os trusts privados interpretativos ou resultantes se formam pela jurisprudência, sem a interferência da vontade de um instituidor. ${ }^{32}$

e nos princípios a ele aplicáveis, que requer um estudo à parte. O mesmo ocorre com os trusts de resultado, mas em grau um pouco menor.

${ }^{30}$ Melhim Namem Chalhub, Negócio Fiduciário, 4a ed., p. 24.

${ }^{31}$ Ibid., p. 26.

${ }^{32}$ Ibid., p. 25. 
O instituidor deverá ter capacidade de fato e de direito para instituir um trust. Em geral, a instituição do trust não obedece a formalidades, exceto no Reino Unido nos casos de trusts envolvendo bens imóveis e nos trusts criados por via testamentária, que exigem instrumento assinado por duas testemunhas. Nos Estados Unidos, cada estado tem, em regra, formalidades específicas para trusts envolvendo bens imóveis. ${ }^{33}$

Para a constituição de um trust não basta apenas a declaração de vontade do instituidor; deve haver, também, a transferência de titularidade ou propriedade dos bens objeto do trust, de acordo com os seus modos de transferência próprios. Se não houver essa transferência, a declaração da intenção de se constituir um trust poderá ser interpretada como sendo, apenas, uma promessa de constituição do trust.

O segundo elemento do trust é o seu objeto, que deverá ser claramente identificado, com indicações de gênero, qualidade e quantidade que o individualizem. Não se admite que o objeto do trust seja descrito por meio de expressões vagas, que não tenham o condão de identificar claramente o bem. Podem ser objeto do trust qualquer bem ou direito de conteúdo econômico ou financeiro, passível de transferência ou que tenha autonomia suficiente em relação ao seu titular. Desta forma, todos os bens que um homem pode legar ou transmitir podem ser objeto do trust. $^{34}$

\subsubsection{Elementos Subjetivos}

São elementos subjetivos do trust: o instituidor (settlor), o trustee e o beneficiário (cestui que trust).

O instituidor é o criador do trust, pois detém a titularidade sobre determinado bem ou direito que formará o trust. Na constituição do trust, o settlor pratica dois atos articulados, isto é, transmite ao trustee a titularidade do bem ou direito, definindo sua

\footnotetext{
${ }^{33}$ Austin Wakeman Scott, The Law of Trusts, p. 294 e 295.

${ }^{34}$ Austin Scott, The Law of Trusts, p. 617 e 618.
} 
destinação, e estabelece as obrigações a serem cumpridas pelo trustee, em decorrência dessa transmissão ${ }^{35}$.

O trustee é a pessoa que recebe a titularidade dos bens ou direitos objeto do trust e deverá administrá-los de acordo com a vontade do instituidor.

O beneficiário é a pessoa em favor de quem o trust é constituído, o qual deterá a propriedade de fruição ou econômica sobre o bem objeto do trust. Importante mencionar que os trusts privados precisam necessariamente ter beneficiários, ao contrário dos trusts relativos a propósitos, em que não há esta exigência pela característica própria desse tipo de trust.

\subsubsection{Investidura, Recusa, Renúncia e Substituição do Trustee}

O trustee é, em regra, escolhido pelo instituidor nos trusts privados expressos e resultantes e nos trusts relativos a propósitos. Nos trusts privados interpretativos, o trustee será a pessoa em relação a qual determinem as regras de equidade que deva gerir seu patrimônio em benefício de terceiros.

\subsubsection{Deveres do Trustee}

A relação entre trustee e beneficiários é considerada de natureza fiduciária. Os deveres do trustee são divididos pela doutrina inglesa entre aqueles introduzidos mais diretamente em relação ao patrimônio envolvido no trust e aqueles introduzidos mais diretamente em relação aos beneficiários ou em vista da proteção dos propósitos que se voltam ao trust. ${ }^{36}$

\footnotetext{
${ }^{35}$ Melhim Namem Chalhub, Trust: perspectivas do direito contemporâneo na transmissão da propriedade para administração de investimentos e garantia, p. 42.

${ }^{36}$ Harold Greville Hanbury, Modern equity: the principles of equity, p. 496 e 521.
} 


\section{1) Deveres em Relação ao Patrimônio}

O principal dever é reunir os bens e direitos que compõem o patrimônio do trust, podendo tomar todas as medidas legais e judiciais para tanto. O trustee deverá conservar o patrimônio segundo as instruções deixadas pelo settlor. O trustee poderá realizar investimentos que assegurem a manutenção do valor do patrimônio, para capacitá-lo à realização dos objetivos do trust. ${ }^{37}$

\section{2) Deveres em Relação aos Beneficiários}

O trustee deverá ter o dever de cuidar do patrimônio a ele confiado, tomando todas as precauções que um homem médio tomaria na administração de seu próprio negócio. $\mathrm{O}$ trustee deverá ter o dever de lealdade que é repartido em dois aspectos: o dever de evitar conflito de interesses e o dever de abster-se de lucros incidentais. O primeiro diz respeito à obrigação imposta ao trustee de não negociar com o trust, no caso de o trust ter em seu patrimônio ativos aplicados a uma determinada atividade ou participação significativa em sociedade dedicada a uma atividade determinada. O trustee não deverá, direta ou indiretamente, comprar ou vender qualquer bem integrante do trust do ou para o trustee ou qualquer de suas afiliadas, ou do ou para um administrador, diretor ou empregado do referido trustee ou de sua afiliada, ou de ou para um parente, empregador, sócio ou outro associado. $^{38}$

Além disso, o trustee é proibído de perceber lucros incidentais em decorrência de suas funções, ou seja, qualquer ganho não incluído na remuneração do trustee autorizada pelo instituidor do trust, por diplomas legais específicos ou finalmente em virtude de determinação dos tribunais. ${ }^{39}$

\footnotetext{
${ }^{37}$ Eduardo Salomão, $O$ trust e o direito brasileiro, p. 38.

${ }^{38}$ Austin Wakeman Scott, The law of trusts, pp. 1193 e ss.

${ }^{39}$ Eduardo Salomão, $O$ trust e o direito brasileiro, pp. 44 e ss.
} 


\subsubsection{Alteração e Extinção do Trust}

Tanto nos Estados Unidos da América como na Inglaterra permite-se que o trustee ou o beneficiário recorram aos Tribunais solicitando a variação dos termos do trust, de forma a preservar bens em torno dos quais se tenha constituído, manter seu valor e assegurar-lhes rentabilidade adequada.

Apenas as cláusulas instrumentais criadas pelo instituidor (ex. política de investimentos, dentre outras) podem ser alteradas. Todavia, as cláusulas materiais referentes às vantagens e direitos conferidos aos beneficiários não podem ser alteradas, exceto no caso de trust de natureza caritativa em razão do interesse público presente nesta espécie de trust.

O trust poderá ser extinto se o trustee se tornar o único beneficiário do trust, pelo decurso do prazo do trust, pela consecução do objetivo do trust ou pela impossibilidade e/ou ilegalidade em atingi-lo.

\subsubsection{Responsabilidade do Trustee}

O trustee deve exercer seus poderes sobre os bens a ele confiados em benefício dos beneficiários ou para a realização dos propósitos para os quais o trust foi constituído. Para tanto, o trustee deverá observar as condições impostas pelo settlor no instrumento de constituição do trust ou ainda as restrições impostas por lei.

É possível que um mesmo trust possua vários trustees que deverão exercer conjuntamente a titularidade dos bens. Em caso de inadimplemento por parte de um ou mais trustee, poderá haver necessidade de intervenção judicial para substituí-lo, sem que necessariamente tenha havido prejuízo ao patrimônio do trust. Basta que o trustee descumpra qualquer condição imposta pelo instituidor do trust ou por lei para nascer o direito de o instituidor e/ou o beneficiário pleitearem a sua substituição do trustee. 
Embora o trustee seja responsável pelo lucro por ele obtido na administração do trust, mesmo que o lucro não tenha sido obtido em razão de quebra do trust, ele não será responsável, exceto se violou algum de seus deveres para com os beneficiários. Se o prejuízo não se deu por sua falha ao tomar as devidas providências para preservar o trust, ou se ele não teve culpa pela quebra do trust, o trustee não será responsabilizado. ${ }^{40}$

Todavia, se o trustee descumprir suas obrigações, causando prejuízos ao patrimônio do trust, o trustee será obrigado a indenizar o beneficiário pelas perdas causadas, mediante o pagamento de indenização por perdas e danos ou, em alguns casos, mediante a restituição de bens integrantes do patrimônio do trust que tenham sido vendidos, doados e/ou de qualquer forma alienados em desconformidade com o que consta do instrumento do trust ou em benefício do trustee e/ou de terceiro. ${ }^{41}$

Tratando-se da responsabilidade do trustee, deve-se ter em mente que o termo "quebra de trust" é extremamente amplo. O Trustee Act de 1925 conferia poderes para que os tribunais eximissem de culpa o trustee que houvesse descumprido o trust, mas que, conforme seu entendimento, houvesse agido honestamente. Hanbury diz ser muito difícil estabelecer princípios de aplicação geral à responsabilização do trustee. Contudo, há uma regra geral que diz o seguinte: ganhos resultantes dos bens do trust pertencem ao cestui que trust, enquanto os prejuízos são suportados pelo trustee. Em outras palavras, o autor diz que o trustee não pode querer compensar a perda de dinheiro do trust, em uma transação, pelo ganho por ele obtido em outra. Para o autor, a responsabilidade do trustee é pelo prejuízo causado aos bens do trust e este prejuízo deve ser demonstrado. Se um trustee descumpre uma obrigação do trust e tal descumprimento resulta em um lucro, este lucro deverá ser revertido em benefício do cestui que trust. ${ }^{42}$

O fato gerador da responsabilidade em caso de quebra do trust com reflexos patrimoniais poderá estar ligado à incorreta aplicação dos fundos do trust em investimentos não permitidos pela legislação aplicável, bem como o seu desvio para benefício de pessoas outras que não os beneficiários, sejam estas pessoas o próprio trustee ou terceiros. ${ }^{43}$

\footnotetext{
${ }^{40}$ Austin Scot, The Law of trusts, v. II, p. 1520.

${ }^{41}$ Ibid., pp. 1522 e 1523.

${ }^{42}$ Harold Greville Hanbury, Modern equity, pp. 264 e ss.

${ }^{43}$ Eduardo Salomão Neto, $O$ trust e o direito brasileiro, p. 53.
} 


\subsection{O fideicomisso Latino-Americano}

O fideicomisso sempre foi conhecido como instituto do direito sucessório. Todavia, alguns países latino-americanos adotaram o fideicomisso para outras finalidades, tais como o fideicomisso financeiro, para permitir a concessão de financiamentos e a ampliação do crédito.

Ricardo J. Alfaro, jurista panamenho, é considerado o fundador da doutrina latinoamericana do fideicomisso, a partir de uma obra chamada "El fideicomisso", na qual ele estudou a necessidade e conveniência de se introduzir na legislação dos países latinoamericanos um instituto novo, semelhante ao trust do direito inglês. Tal estudo foi publicado pela Imprenta Nacional de Panamá em $1920 .^{44}$

Na Terceira Conferência Científica Panamericana realizada em Lima em 1924, Alfaro propôs um Projeto de Lei de Fideicomisso (também conhecido como "Projeto Panamenho de Alfaro"). O referido Projeto foi sancionado como lei em 1925 e, posteriormente, em Porto Rico em 1928. O fideicomisso financeiro foi adotado pelos seguintes países: Colômbia (1923), México (1924), Chile (1925), Bolívia (1928), Costa Rica (1936), El Salvador (1937), Venezuela (1940), Nicarágua (1940), Guatemala (1946), Equador (1948), Honduras (1950), Argentina (1995) e Paraguai (1996). ${ }^{45}$

Como se pode ver, o Brasil foi um dos poucos países que manteve o instituto do fideicomisso unicamente para fins sucessórios ${ }^{46}$. Importante mencionar, no entanto, que existe no Brasil uma série de leis esparsas que regulamentam negócios de natureza fiduciária semelhantes ao fideicomisso financeiro praticado nos países da América Latina, tais como: alienação fiduciária em garantia, cessão fiduciária de crédito, dentre outras.

\footnotetext{
${ }^{44}$ Gustavo Américo Esparza, El fideicomisso: introducción a un estúdio comparado de su legislación en Argentina, México y Panamá, p. 44.

${ }^{45}$ Claudio M. Kiper e Silvio V. Lisoprawski. Tratado de fideicomisso, p. 147, nota 9.

${ }^{46}$ Os artigos 1.951 até 1960 do Código Civil Brasileiro regulamentam a substituição fideicomissária. O artigo 1951 assim dispõe: "pode o testador instituir herdeiros ou legatários, estabelecendo que, por ocasião de sua morte, a herança ou o legado se transmita ao fiduciário, resolvendo-se o direito deste, por sua morte, a certo tempo ou sob certa condição, em favor de outrem, que se qualifica de fideicomissário."
} 
Num primeiro momento (1920), Alfaro definiu o fideicomisso como um mandato irrevogável, em virtude do qual se transmite ao fiduciário determinados bens para que deles e seus produtos sejam utilizados segundo a vontade de quem os transmite, chamado fideicomitente, em benefício de um terceiro chamado fideicomissário. A utilização da figura do mandato para explicar a relação fiduciária não foi fruto de um erro conceitual nem uma explicação diversa das fontes romanas do instituto, mas sim a intenção de explicar aos advogados latino-americanos, desconhecedores de uma figura tão peculiar como o fideicomisso, que o fiduciário atuava em verdadeiro interesse alheio. Posteriormente, Alfaro corrigiu a definição dizendo que o fideicomisso é o ato pelo qual se transmitem certos bens a uma pessoa chamada fiduciário, para que deles se utilizem segundo as instruções da pessoa que os transmite, chamada fideicomitente, em benefício de um terceiro chamado fideicomissário. ${ }^{47}$

Atualmente, o fideicomisso é regulado no Panamá pela Lei nº 1, de 05.01.1984, que individualiza o fideicomitente (quem transmite os bens), o fiduciário (quem cumpre o encargo) e o fideicomissário ou beneficiário (a favor de quem é cumprido o encargo). A referida lei contempla tanto o fideicomisso como negócio jurídico geral, como também testamentário, sendo uma lei que se dirige mais para as entidades de direito público quando estas atuam como fiduciários. O objeto sobre o qual pode recair o fideicomisso é amplo, podendo compreender bens de qualquer natureza, presentes ou futuros, e permite afetar todo um patrimônio ou parte dele. Podem atuar como fiduciários as pessoas físicas, jurídicas e de direito público. Esta lei possui a particularidade de tratar de problemas de direito internacional privado relacionados ao fideicomisso (artigos 38 a $40^{48}$ ). ${ }^{49}$

${ }^{47}$ Claudio M. Kiper e Silvio V. Lisoprawski. Tratado de fideicomisso, p. 148.

${ }^{48}$ Lei 1, de 05.01.1984 - Artigo 38. Os fideicomissos constituídos de acordo com as leis da República do Panamá, reger-se-ão pelas leis panamenhas. No entanto, poderão utilizar em sua execução de uma lei estrangeira se assim dispuser o instrumento de fideicomisso. O fideicomisso, assim como os seus bens, poderão ser transferidos ou submetidos às leis da jurisdição de outro país, segundo o disposto no instrumento de fideicomisso. Artigo 39. Os fideicomissos constituídos antes da vigência desta lei reger-se-ão pelas leis vigentes ao tempo de sua constituição, mas poderão acolher a presente lei a qualquer tempo, mediante declaração escrita do fideicomitente, fiduciário ou beneficiário. Artigo 40. Os fideicomissos constituídos em conformidade com uma lei estrangeira poderão escolher a lei panamenha, desde que feita uma declaração nesse sentido, sujeitando-se aos requisitos de fundo e às formalidades estabelecidas nesta lei para a constituição do fideicomisso. (tradução livre de: Ley 1, de 05.01.1984 - Artículo 38. Los fideicomisos constituidos de acuerdo con las leyes de la República de Panama, se regirán por la Ley panameña. Sin embargo, podrán ejecutarse en sus ejecución a una Ley extranjera si así lo dispone el instrumento de fideicomiso. El fideicomiso, así como los bienes del mismo, podrán trasladarse o someterse a las leyes o jurisdicción de otro país, según lo dispuesto en el instrumento de fideicomiso. Artículo 39. Los fideicomisos constituidos antes de la vigencia de esta Ley se regirán por las leyes vigentes al tiempo de su constitución: pero podrán acogerse a la presente Ley en cualquier tiempo mediante declaración escrita del fideicomitente, 
$\mathrm{Na}$ definição de Pedro Maria Giraldi ${ }^{50}$, fideicomisso é o negócio jurídico consistente na afetação de um patrimônio com um propósito determinado em benefício de alguém e a cargo de um sujeito alheio à finalidade de realizar os atos tendentes ao seu cumprimento.

Pela definição acima, é possível inferir-se que a principal característica do fideicomisso latino-americano é que os bens fideicomitidos formam um patrimônio separado $^{51}$, que é afetado ao cumprimento de uma destinação específica.

\subsubsection{O fideicomisso no México}

O México introduziu o fideicomisso em sua legislação pela Ley de Instituciones de Crédito de 1924 (“LIC”). Todavia, o fideicomisso, como negócio típico e distinto de outros negócios jurídicos, somente surgiu por meio da Ley General de Títulos y Operaciones de Crédito, de 27.08.1932 (“LGTOC”), cuja última reforma ocorreu em 20.08.2008. As regras gerais do fideicomisso estão contempladas nos artigos 381 até 394 da Seção Primeira do

fiduciario y beneficiario. Artículo 40. Los fideicomisos constituidos de conformidad con una Ley extranjera podrán acogerse a la Ley panameña, siempre que el fideicomitente y el fiduciario o este solo, si así lo autoriza el instrumento de fideicomiso, hagan una declaración en tal sentido, sujetándose a los requisitos de fondo y a las formalidades establecidas en esta Ley para la constitución del fideicomiso.)

${ }^{49}$ Gustavo Américo Esparza, El fideicomisso: introducción a un estudio comparado de su legislación en Argentina, México y Panamá, p. 45.

${ }^{50}$ Fideicomisso (Ley 24.441), p. 21.

${ }^{51}$ Artigo 15 da Lei 1, de 1984 do Panamá - "Os bens do fideicomisso constituirão um patrimônio separado dos bens pessoais do fiduciário para todos os efeitos legais e não poderão ser arrestados nem embargados, exceto por obrigações incorridas ou por danos causados na execução do fideicomisso ou por terceiros quando os bens forem transferidos ou retidos mediante fraude ou em prejuízo de seus direitos." (tradução livre de: "Los bienes del fideicomiso constituirán un patrimonio separado de los bienes personales del fiduciario para todos los efectos legales y no podrán ser secuestrados ni embargados, salvo por obligaciones incurridas o por danos causados con ocasión de la ejecución de fideicomiso o por terceros cuando se hubieren traspasado o retenido los bienes con fraude y en perjuicio de sus derechos.”)

No mesmo sentido, artigo 386 da Lei Geral de Títulos e Operações de Créditos do México (Ley General de Títulos y Operaciones de Crédito): "podem ser objeto do fideicomisso toda a classe de bens e direitos, exceto aqueles que, conforme a lei, sejam estritamente pessoais em relação ao seu titular. Os bens entregues em fideicomisso se consideram afetados ao fim a que se destinam, consequentemente, somente poderão ser exercitados em relação a eles os direitos e ações que se refiram ao mencionado fim." (tradução livre de: pueden ser objeto del fideicomiso toda clase de bienes y derechos, salvo aquellos que, conforme a la ley, sean estrictamente personales de su titular. Los bienes que se den en fideicomiso se considerarán afectos al fin a que se destinan y, en consecuencia, sólo podrán ejercitarse respecto a ellos los derechos y acciones que al mencionado fin se refieran..."

Também no mesmo sentido, o artigo 14 da Lei 24.441 da Argentina: Os bens fideicomitidos constituem um patrimônio separado do patrimônio do fiduciário e do fiduciante... (tradução livre de"los bienes fideicomitidos constituyen un patrimonio separado del patrimonio del fiduciario y del fiduciante.) 
Capítulo V da LGTOC, enquanto o fideicomisso de garantia encontra-se regulado nos artigos 394 até 407 da Seção Segunda do Capítulo V da lei.

O artigo 381 da referida lei estabelece que em razão do fideicomisso, o fideicomitente transmite a uma instituição fiduciária a propriedade ou a titularidade de um ou mais bens ou direitos, para ser destinados a fins lícitos e determinados, cabendo à própria instituição fiduciária a realização de tais fins. Importante mencionar que a antiga redação do artigo 346 da LGTOC (originalmente publicada em 27.08.1932) dispunha que em razão do fideicomisso, o fideicomitente destinava certos bens a um fim lícito determinado, encomendando a realização desse fim a uma instituição fiduciária.

Como bem salientam Kiper e Lisoprawski ${ }^{52}$, existiam autores mexicanos que sustentavam que não havia transmissão de propriedade fiduciária, e a propriedade continuava sendo do instituidor - em "estado latente", mas destinada a um fim lícito e convencionalmente determinado, que a lei protegia sob a denominação de "afetação" ou “destino". Eles sustentavam que a LGTOC não se referia expressamente à transmissão da propriedade ao fiduciário, como efeito do fideicomisso, nem que os bens fideicomitidos formavam um patrimônio autônomo sem sujeito titular ${ }^{53}$. Com essa nova definição trazida pelo artigo 381 da LGTOC, não há dúvida de que há transmissão fiduciária da propriedade ou titularidade dos bens fideicomitidos, restando prejudicada a discussão anteriormente trazida pela doutrina.

O fideicomisso mexicano possui pelo menos 2 (dois) sujeitos: (i) o fideicomitente, que poderá ser qualquer pessoa física ou jurídica com capacidade para transmitir a propriedade ou a titularidade dos bens ou direitos objeto do fideicomisso, assim como as autoridades judiciais ou administrativas competentes para tanto; e (ii) o fideicomissário, que poderá ser qualquer pessoa que tenha a capacidade necessária para receber o benefício que o fideicomisso implica. No fideicomisso financeiro, uma ou mais instituições fiduciárias, expressamente autorizadas a funcionar por lei, poderão desempenhar a função de fiduciário, estabelecendo a ordem e as condições de sua substituição.

\footnotetext{
${ }^{52}$ Tratado de Fideicomiso, p. 175.

53 Nesse sentido é a opinião de Jorge Alfredo Domínguez Martínez, Dos Aspectos de La Esencia del Fideicomisso Mexicano, p. 19-20.
} 
O fideicomisso deverá ser sempre constituído por escrito e o fideicomissário poderá ser designado pelo fideicomitente no próprio ato constitutivo do fideicomisso ou em ato posterior. O fideicomisso será válido ainda que se constitua sem indicação de um fideicomissário, sempre que seus fins sejam lícitos e determinados e conste a aceitação do encargo por parte do fiduciário. É nulo o fideicomisso que se constitua em benefício do fiduciário.

A instituição fiduciária poderá ser fideicomissária nos fideicomissos que tenham por fim servir de instrumento de pagamento de obrigações não cumpridas, e para os créditos concedidos pela própria instituição para a realização de atividades empresariais. Nesse sentido, as partes deverão acordar sobre os termos e condições para dirimir possíveis conflitos de interesses.

O fideicomitente poderá designar vários fideicomissários que receberão os benefícios do fideicomisso simultânea ou sucessivamente, exceto no caso do inciso II do artigo 394 da LGTOC $^{54}$. Quando existirem dois ou mais fideicomissários e estes devam ser consultados, se não houver previsão no fideicomisso, as decisões serão tomadas por maioria dos votos computados por representação e não por pessoa. Em caso de empate, o juiz de primeira instância do lugar do domicílio do fiduciário decidirá.

Quanto ao objeto do fideicomisso poderão ser toda a classe de bens e direitos, exceto aqueles em que a lei estipular que são personalíssimos em relação ao seu titular. Nos termos do artigo 386 da LGTOC, os bens a serem dados em fideicomisso serão considerados afetados ao fim a que se destinam e, conseqüentemente, somente poderão ser exercidos em relação a eles os direitos e ações vinculados à sua finalidade, exceto as ações expressamente reservadas pelo fideicomitente, as que para ele derivem do próprio fideicomisso ou as ações adquiridas legalmente em relação a tais bens anteriormente à constituição do fideicomisso, pelo fideicomissário ou por terceiros.

\footnotetext{
${ }^{54}$ O inciso II do artigo 394 da lei assim dispõe: "aqueles nos quais o benefício é concedido a diversas pessoas sucessivamente que devam substituir-se por morte da anterior, exceto nos casos em que a substituição se realize em favor de pessoas que estejam vivas ou já concebidas quando da morte do fideicomitente" (tradução livre de: "II.- Aquellos en los cuales el beneficio se conceda a diversas personas sucesivamente que deban substituirse por muerte de la anterior, salvo el caso de que la substitución se realice en favor de personas que estén vivas o concebidas ya, a la muerte del fideicomitente.")
} 
A instituição fiduciária deverá registrar contabilmente tais bens e direitos e mantêlos de forma segregada de seus próprios ativos. O fideicomisso constituído em fraude contra terceiros poderá, a todo tempo, ser declarado nulo por todos os interessados.

O fideicomisso que tiver por objetos bens imóveis deverá ser registrado no Registro Público do lugar onde os bens estiverem situados. O fideicomisso produzirá efeitos em relação a terceiros, a partir da data de seu registro. Por outro lado, o fideicomisso que tiver por objeto bens móveis, produzirá efeitos contra terceiros a partir da data em que se cumprirem os seguintes requisitos, nos termos do artigo 389 da LGTOC:

(i) Se tratar-se de um crédito não negociável ou de um direito pessoal, a partir da notificação do devedor sobre a constituição do fideicomisso;

(ii) Se tratar-se de um título nominativo, a partir de seu endosso à instituição fiduciária e desde que conste dos registros do emissor;

(iii) Se tratar-se de coisa corpórea ou de títulos ao portador, a partir do momento em que estiverem em poder da instituição fiduciária.

O fideicomissário terá todos os direitos previstos em lei ou no ato constitutivo do fideicomisso de exigir o seu cumprimento pela instituição fiduciária, bem como o de contestar a validade dos atos que a instituição fiduciária praticar em prejuízo do fideicomissário ou do próprio fideicomisso, com má-fé ou com excesso de direitos, bem como o direito de reivindicar os bens que tenham saído do patrimônio objeto do fideicomisso. A instituição fiduciária terá todos os direitos e ações necessárias para o cumprimento do fideicomisso, exceto pelas limitações ou restrições legais ou as constantes do ato que instituiu o fideicomisso, obrigando-se a cumprir o fideicomisso nas condições constantes do ato constitutivo, não podendo escusar-se ou renunciar seu encargo senão por causas graves, a critério do juiz, responsabilizando-se pelas perdas ou danos causados por sua culpa aos bens objeto do fideicomisso.

O fideicomisso se extingue:

a) Pela realização do fim para o qual foi constituído;

b) Pela impossibilidade de sua execução; 
c) Pela impossibilidade do cumprimento da condição suspensiva de que dependa, ou caso ela não se verifique dentro do término do prazo estipulado no ato de constituição do fideicomisso ou, em sua ausência, dentro do prazo de 20 anos após sua constituição;

d) Pelo cumprimento da condição resolutiva a que estiver sujeito;

e) Por acordo escrito entre fideicomitente, fiduciário e fideicomissário;

f) Por revogação feita pelo fideicomitente, quando este tiver reservado expressamente este direito quando da constituição do fideicomisso;

g) Nos casos de fideicomisso constituído em fraude contra credores, e

h) Em caso de falta de pagamento da remuneração devida à instituição fiduciária por sua atuação como fiduciário, nos termos estabelecidos no respectivo contrato, por um período igual ou superior a 3 (três) anos. Neste caso, a instituição fiduciária poderá dar por encerrado o fideicomisso, sem qualquer responsabilidade, devendo notificar o fideicomitente e o fideicomissário de sua decisão, fixando um prazo de 15 (quinze) dias úteis para que eles paguem o valor da dívida. Se não houver pagamento após o transcurso do referido prazo, a instituição fiduciária transmitirá os bens ou direitos em seu poder ao fideicomitente ou ao fideicomissário, conforme o caso. Se, após inúmeros esforços da instituição fiduciária, não forem encontrados o fideicomitente ou o fideicomissário, a instituição financeira poderá apropriar-se dos recursos líquidos e, em se tratando de recursos ilíquidos, poderá aliená-los e convertêlos em recursos líquidos para sua posterior apropriação.

Extinto o fideicomisso, se não houver estipulação em sentido diverso, os bens ou direitos em poder da instituição fiduciária serão transmitidos ao fideicomitente ou ao fideicomissário, conforme o caso. Em caso de dúvida ou oposição acerca da referida transmissão, o juiz de primeira instância competente do lugar do domicílio da instituição fiduciária, após ouvir as partes, decidirá a questão.

São proibidos: os fideicomissos secretos, aqueles instituídos em benefício de diversas pessoas sucessivamente que devam substituir-se por morte da anterior, exceto nos casos em que a substituição se realize em favor de pessoas que já estejam vivas ou concebidas quando da morte do fideicomitente, e aqueles cuja duração seja superior a 50 
(cinqüenta) anos, quando se designar como beneficiário uma pessoa jurídica que não seja de direito público ou instituição de beneficência. Todavia, podem constituir-se com duração superior a 50 (cinqüenta) anos quando o fideicomisso destinar-se à manutenção de museus de caráter científico ou artístico sem fins lucrativos.

\subsubsection{O fideicomisso de garantia}

Somente as instituições financeiras abaixo poderão atuar como fiduciárias nos fideicomissos que tenham por fim garantir ao fideicomissário o cumprimento de uma obrigação:

(i) Instituições de crédito;

(ii) Instituições de seguros;

(iii) Instituições de fianças;

(iv) Casas de bolsa;

(v) Sociedades financeiras de objeto múltiplo a que se refere o artigo 87-B da Ley General de Organizaciones y Actividades Auxiliares del Crédito ${ }^{55}$;

(vi) Armazéns gerais de depósitos; e

(vii) Uniões de crédito.

As instituições e sociedades acima mencionadas poderão ser fiduciárias e fideicomissárias ao mesmo tempo nos casos de fideicomisso destinado a garantir as obrigações em seu favor. Neste caso, as partes deverão acordar os termos e condições para dirimir possíveis conflitos de interesses. Um mesmo fideicomisso poderá ser utilizado para garantir simultânea ou sucessivamente diferentes obrigações que o fideicomitente contraia com um ou vários credores. Cada fideicomissário estará obrigado a notificar a instituição fiduciária que a obrigação a seu favor foi extinta, caso em que ficam sem efeitos os direitos a ele derivados do fideicomisso. A notificação deverá ser entregue mediante notário público em até 5 (cinco) dias úteis seguintes à data em que tiver recebido o pagamento. A partir do momento em que o fiduciário receber a mencionada notificação, o fideicomitente poderá designar um novo fideicomissário ou informar à instituição fiduciária que foi

${ }^{55}$ Nos termos do Artigo 87-B da referida lei, as sociedades financeiras de objeto múltiplo são sociedades anônimas que tenham por objeto em seus Estatutos a prática habitual e profissional de uma ou mais das seguintes atividades: concessão de crédito, arrendamento mercantil ou faturização (factoring). Tais sociedades serão consideradas como financeiras. 
realizado o fim para o qual o fideicomisso foi constituído. O fideicomissário que não entregar oportunamente ao fiduciário tal notificação ficará obrigado a ressarcir o fideicomitente de todos os danos e prejuízos que este incorrer.

Tratando-se de fideicomisso de garantia sobre bens móveis, as partes poderão acordar que um ou mais fideicomitentes tenham direito de: (i) fazer uso dos bens fideicomitidos, os combinem ou empreguem na fabricação de outros bens, sempre e quando não houver diminuição de seu valor e os bens produzidos passem a fazer parte do fideicomisso de garantia em questão; (iii) percebam ou utilizem os frutos e produtos dos bens fideicomitidos; e (iii) dêem instruções ao fiduciário para alienar os bens fideicomitidos, sem responsabilidade para este, sempre e quando dita alienação estiver de acordo com o curso normal das atividades do fideicomitente. Nestes casos cessarão os efeitos da garantia fiduciária e os direitos de seqüela em relação aos adquirentes de boa-fé.

Os bens ou direitos que o fiduciário receber ou tiver direito a receber em pagamento pela alienação dos referidos bens ficarão afetados ao fideicomisso. As partes deverão acordar desde a constituição do fideicomisso sobre os lugares em que deverão encontrar-se os bens fideicomitidos; a remuneração mínima que o fiduciário deverá receber pela venda ou transferência de bens móveis fideicomitidos, a indicação da pessoa ou pessoas que o fiduciário, por instruções do fideicomitente, poderá vender ou transferir referidos bens, podendo, estipular as características ou categorias que permitam identificá-las, assim como o destino que o fiduciário deverá dar ao dinheiro, bens ou direitos que receber em pagamento, a informação que o fideicomitente deverá entregar ao fideicomissário sobre a transformação, venda ou transferência dos mencionados bens, a forma de avaliar os bens fideicomitidos, e os termos em que serão acordados. Em caso de inadimplemento dos acordos celebrados, o crédito garantido pelo fideicomisso será considerado antecipadamente vencido.

As partes poderão convencionar que a posse dos bens em fideicomisso fique com terceiros ou com o fideicomitente. Quando corresponder ao fideicomitente ou a um terceiro a posse material dos bens fideicomitidos, eles a terão na qualidade de depositário e estarão obrigados a conservá-los como se fossem próprios e a não utilizá-los para fins diversos daquele em que foi pactuado, respondendo pelos prejuízos causados a terceiros. Tal 
responsabilidade não poderá ser exigida do fiduciário. Neste caso, correrão por conta do fideicomitente os gastos necessários para a devida conservação, reparação, administração e recuperação dos bens fideicomitidos.

Se os bens fideicomitidos se perderem ou se deteriorarem, o fideicomissário tem direito de exigir do fideicomitente, quando este for o devedor da obrigação garantida, a transmissão em fideicomisso de outros bens ou o pagamento da dívida ainda que antes do prazo convencionado. Os riscos de perda, dano ou deterioração do valor dos bens fideicomitidos correm por conta da parte que estiver na posse dos mesmos, devendo permitir-se a outras partes que os inspecionem a fins de verificar seu peso, quantidade e estado de conservação geral.

O contrato de fideicomisso deverá prever que se o valor de mercado dos bens fideicomitidos diminuírem a ponto de não cobrir o valor do principal e dos acessórios da dívida que garantem, o devedor deverá entregar bens adicionais para restabelecer o valor original. Caso contrário, o crédito poderá ser considerado antecipadamente vencido, tendo o credor que notificar judicialmente o devedor sobre tal fato.

No fideicomisso de garantia, as partes poderão acordar a forma em que a instituição fiduciária poderá alienar extrajudicialmente, a título oneroso, os bens ou direitos em fideicomisso, desde que, no mínimo, se pactue o seguinte:

(i) Que a instituição fiduciária inicie o procedimento de alienação extrajudicial dos bens ou direitos em fideicomisso, quando receber dos fideicomissários uma comunicação por escrito solicitando a referida alienação e identificando o descumprimento de uma ou mais obrigações garantidas;

(ii) Que a instituição fiduciária comunique por escrito aos fideicomitentes, no endereço de seu domicilio estipulado no fideicomisso ou em ato posterior, a solicitação prevista no item anterior, junto com uma cópia da mesma, sendo que somente poderão opor-se à alienação aqueles que exibirem o importe da dívida, alegando o cumprimento de uma ou mais obrigações identificadas na solicitação por um ou todos os fideicomissários, na conformidade com o item 
anterior, ou apresentem documento que comprove a prorrogação de prazo ou a novação da obrigação;

(iii) Que somente no caso de que os fideicomitentes não aleguem, em conformidade com o previsto no item anterior, o cumprimento das obrigações garantidas ou, conforme o caso, sua novação ou prorrogação, a instituição fiduciária promoverá a alienação extrajudicial de ditos bens ou direitos fideicomitidos, nos termos e condições pactuados no fideicomisso; e

(iv) Os prazos para levar a cabo os atos estipulados nos itens anteriores.

\subsubsection{O fideicomisso na Argentina}

O ponto de partida para a instituição do fideicomisso na Argentina ocorreu com a regulamentação do domínio fiduciário no Código Civil Argentino feita por Vélez Sársfield. O domínio fiduciário é uma espécie do gênero domínio imperfeito. O domínio imperfeito é aquele que se resolve ao fim de um certo tempo ou com o advento de uma condição ${ }^{56}$. A antiga redação do artigo 2.662 do Código Civil $^{57}$ definia o domínio fiduciário como sendo aquele em que se adquire um fideicomisso singular, subordinado a durar somente até o cumprimento de uma condição resolutiva ou até o vencimento de um prazo resolutivo, para o efeito de restituir a coisa a um terceiro.

Atualmente, o fideicomisso encontra-se regulado na Lei $\mathrm{n}^{\circ} 24.441$, sancionada pelo Congresso Nacional em 22.12.1994 ${ }^{58}$ e promulgada pelo Poder Executivo por meio do Decreto 43/95, de 09.01.1995, iniciando sua vigência em 24.01.1995, com exceção dos artigos 83 e 84, cuja vigência iniciou-se em 01.03.1995. A Lei $\mathrm{n}^{\circ} 24.441$ alterou a redação do artigo 2.662 do Código Civil que passou a vigorar com a seguinte redação:

"Dominio fiduciario es el que se adquiere en razón de un fideicomiso constituido por contrato o por testamento, y está sometido a durar solamente hasta la extinción del fideicomiso, para el efecto de entregar la cosa a quien corresponda según el contrato, el testamento o la ley."

\footnotetext{
${ }^{56}$ Claudio Marcelo Kiper e Silvio V. Lisoprawski, Tratado de fideicomiso, p. 31.

57 Tradução livre de: "dominio fiduciario es el que se adquiere en un fideicomiso singular, subordinado a durar solamente hasta el cumplimiento de una condición resolutiva o hasta el vencimiento de un plazo resolutivo, para el efecto de restituir la cosa a un tercero."

${ }^{58}$ Ley de Fideicomisos
} 
A Lei $\mathrm{n}^{\circ} 24.441$ regula o fideicomisso de uma forma geral e, também, o fideicomisso financeiro. $\mathrm{O}$ artigo $1^{\circ}$ da Lei $\mathrm{n}^{\circ} 24.441$ diz que ocorre o fideicomisso quando uma pessoa (fiduciante) transmite a propriedade fiduciária de bens determinados à outra (fiduciário), que se obriga a utilizá-la em benefício de quem for designado no contrato como beneficiário, e a transmiti-lo ao fiduciante, ao beneficiário ou ao fideicomissário após o cumprimento de um prazo ou condição.

No fideicomisso argentino existem usualmente 3 (três) sujeitos, a saber: (i) o fiduciante: é aquele que detém a propriedade fiduciária do bem e o transmite ao fiduciário; (ii) o fiduciário: que poderá ser qualquer pessoa física ou jurídica, exceto para fideicomisso financeiro em que somente instituições financeiras autorizadas a funcionar poderão atuar como fiduciário. O fiduciário é aquele que recebe o bem, obrigando-se a dele utilizá-lo de acordo com as instruções do fiduciante; (iii) o beneficiário ou fideicomissário: que poderá ser uma ou mais pessoas físicas ou jurídicas, existentes ou não, ao tempo da celebração do contrato de fideicomisso, que são aqueles em favor de quem o fideicomisso é constituído. Se o beneficiário não existir ao tempo da celebração do contrato de fideicomisso, torna-se necessário que o referido contrato contenha os dados que possam individualizar o beneficiário no futuro.

Tradicionalmente o beneficiário e o fideicomissário são a mesma pessoa. Todavia, admite-se que beneficiário e fideicomissário sejam sujeitos distintos e, neste caso, o beneficiário será aquele em cujo benefício se administram os bens fideicomitidos, enquanto o fideicomissário será o destinatário final dos bens fideicomitidos, uma vez cumprido o prazo ou as condições a que se sujeitam os referidos bens.

Poderá, ainda, haver mais de um beneficiário e todos eles terão os mesmos benefícios, exceto se de outro modo estipulado no contrato de fideicomisso. Poderão ser designados beneficiários substitutos em caso de não aceitação, renúncia ou morte do beneficiário original. Se nenhum beneficiário aceitar o fideicomisso, ou se todos renunciarem ou se não chegarem a existir, o fideicomissário será o beneficiário. 
Se o fideicomissário não chegar a existir, renunciar ou não aceitar o fideicomisso, o beneficiário será o próprio fiduciante. Salvo disposição em contrário expressamente manifestada pelo fiduciante, o direito do beneficiário poderá ser transmitido por ato entre vivos ou causa mortis.

Como bem salientam Kiper e Lisoprawski, o contrato que institui o fideicomisso é um contrato típico, bilateral, consensual e formal, sujeitando-se às regras sobre capacidade, consentimento, legitimação, objeto e demais regras gerais sobre contratos ${ }^{59}$. Nos termos do artigo $4^{\circ}$ da Lei $n^{o}$ 24.441, o contrato de fideicomisso deverá indicar o beneficiário; individualizar os bens objeto do contrato e quando não for possível individualizá-los, deverá constar a descrição dos requisitos e características que os referidos bens deverão possuir; determinar o modo pelo qual outros bens poderão ser incorporados ao fideicomisso; o prazo ou a condição a que se sujeita a propriedade fiduciária, que não poderá ser superior a 30 (trinta) anos a contar de sua constituição, exceto se o beneficiário for incapaz, caso em que ele poderá durar até sua morte ou até que cesse sua incapacidade; o destino dos bens para a consecução da finalidade do fideicomisso; e os direitos e obrigações do fiduciário e o modo de sua substituição.

O beneficiário poderá solicitar que o fiduciário preste contas na forma prevista contratualmente, não podendo tal prestação ser feita em período superior a 1 (um) ano e não podendo o contrato de fideicomisso liberá-lo dessa obrigação. O contrato de fideicomisso também não poderá liberar o fiduciário das obrigações decorrentes de culpa e dolo que ele possa vir a incorrer, assim como da proibição de adquirir para si os bens objeto de fideicomisso. Salvo estipulação em contrário, o fiduciário terá direito ao reembolso dos seus gastos e a remuneração. Se o contrato não houver fixado a remuneração do fiduciário, o juiz a fixará tendo em vista as atribuições do fiduciário e a importância dos deveres que ele deverá cumprir.

Cessará a atuação do fiduciário por: a) remoção judicial em razão do descumprimento de suas obrigações, por pedido feito pelo fiduciante ou pelo beneficiário com citação do fiduciante; b) pela morte ou incapacidade jurídica declarada, se o fiduciário for pessoa física; c) pela dissolução, se o fiduciário for pessoa jurídica; d) pela falência ou

\footnotetext{
${ }^{59}$ Tratado de fideicomiso, p. 187.
} 
liquidação; e) pela renúncia se o contrato autorizá-la expressamente, cujos efeitos ocorrerão após a transferência do patrimônio objeto do fideicomisso ao fiduciário substituto. Existindo uma causa de cessação da atuação do fiduciário, o fiduciário será substituído por um substituto nomeado no contrato ou de acordo com o procedimento previsto por ele. Se o contrato não estipular fiduciário substituto ou se este não aceitar o encargo, o juiz designará como fiduciário uma instituição financeira ou uma sociedade especialmente autorizada a funcionar pela Comisión Nacional de Valores.

O artigo 11 da Lei $\mathrm{n}^{\circ} 24.441$ dispõe que sobre os bens fideicomitidos se constitui uma propriedade fiduciária, que se rege pelo disposto na Lei $\mathrm{n}^{\circ} 24.441$ e pelo disposto no título VII do livro III do Código Civil, quando se trate de coisas, ou às regras correspondentes à natureza dos bens quando estes não forem coisas.

Kiper e Lisoprawski ensinam que pelo contrato de fideicomisso o fiduciante pode transmitir ao fiduciário um direito de propriedade sobre uma coisa ou outra classe de direito patrimonial (ex. um título de crédito). Todavia, para o direito argentino somente no primeiro caso há propriedade fiduciária (denominado domínio fiduciário pelo Código Civil argentino). Se o negócio fiduciário tem por fim transmitir uma propriedade sobre um bem, haverá propriedade fiduciária. Se outra classe de bens for transmitida ao fiduciário, aplicarse-ão as normas que correspondam à natureza dos referidos bens. Tal solução é coerente com a teoria geral de direitos reais, pois estes somente podem ter por objeto coisas certas, determinadas, atualmente existentes e que estão no comércio. Não se concebe o direito real de coisas incertas ou futuras. ${ }^{60}$

A propriedade fiduciária somente terá efeito perante terceiros no momento em que forem cumpridas as formalidades exigidas de acordo com a natureza dos referidos bens. Em se tratando de bens sujeitos a registro, a propriedade fiduciária efetivar-se-á após o registro. $\mathrm{O}$ contrato de fideicomisso poderá estabelecer que o fiduciário adquirirá a propriedade fiduciária de outros bens que adquirir com os frutos dos bens fideicomitidos ou com o produto de atos de disposição dos mesmos.

${ }^{60}$ Tratado de fideicomiso, p. 38. 
Os bens fideicomitidos constituem um patrimônio separado do patrimônio do fiduciário e do fiduciante. A responsabilidade objetiva do fiduciário se limita ao valor da coisa fideicomitida cujo risco ou vício tenha dado causa ao dano, se o fiduciário não puder razoavelmente assegurá-lo.

Os bens fideicomitidos não estão sujeitos a ação singular ou coletiva dos credores do fiduciário. Também não estão sujeitos aos credores do fiduciante, exceto em caso de fraude. Os credores do beneficiário poderão exercer seus direitos sobre os frutos dos bens fideicomitidos.

Os bens do fiduciário não responderão pelas obrigações contraídas na execução do fideicomisso, que só serão satisfeitas com os bens fideicomitidos. Se eles forem insuficientes para satisfazer essas obrigações, não dará lugar a declaração de sua falência. Nesse caso, proceder-se-á à liquidação, que estará a cargo do fiduciário, que deverá alienar os bens integrantes do fideicomisso, entregando o produto aos credores, conforme a ordem de privilégios prevista para falência; em se tratando de fideicomisso financeiro serão aplicáveis as normas do artigo 24 da referida Lei $n^{\circ} 24.441$, que serão adiante comentadas.

O fiduciário poderá dispor ou gravar os bens fideicomitidos quando for necessário aos fins do fideicomisso, sem que para tanto seja necessário o consentimento do fiduciante ou do beneficiário, a menos que o contrato tenha previsão em sentido contrário.

O fiduciário tem legitimidade para propor todas as ações necessárias à defesa dos bens fideicomitidos, tanto contra terceiros como contra o beneficiário. O juiz poderá autorizar o fiduciante ou o beneficiário a praticar tais ações em substituição ao fiduciário, quando este não o fizer sem motivo razoável.

O fideicomisso se extinguirá por: a) cumprimento do prazo ou da condição a que se submeter ou ao vencimento do prazo máximo estipulado por lei; b) a revogação do fiduciante se houver previsão expressa sobre esta faculdade, sendo que tal revogação não terá efeito retroativo; c) qualquer outra causa prevista no contrato. Extinto o fideicomisso, o fiduciário estará obrigado a entregar os bens fideicomitidos ao fideicomissário ou aos seus sucessores, entregando a eles os instrumentos e informações acerca dos registros correspondentes aos referidos bens. 


\subsubsection{O fideicomisso financeiro}

O fideicomisso financeiro está regulado nos artigos 19 e seguintes da Lei no 24.441 . $\mathrm{O}$ fideicomisso financeiro sujeita-se às regras gerais previstas para o fideicomisso, mas a sua particularidade é que somente instituições financeiras ou sociedades especialmente autorizadas a funcionar pela Comisión Nacional de Valores podem atuar como fiduciário, e os beneficiários serão os titulares dos certificados de participação na propriedade fiduciária ou de títulos representativos da dívida garantidos pelos bens assim transmitidos. Referidos certificados de participação ou títulos de dívida serão considerados valores mobiliários e poderão ser objeto de oferta pública. A Comisión Nacional de Valores é a autoridade que regula o fideicomisso financeiro.

O contrato de fideicomisso financeiro deverá conter além dos requisitos constantes do artigo $4^{\circ}$ da referida lei, as condições de emissão dos certificados de participação ou dos títulos representativos de dívida. Os certificados de participação serão emitidos pelo fiduciário, enquanto os títulos representativos de dívidas garantidos pelos bens fideicomitidos poderão ser emitidos pelo fiduciário ou por terceiros, conforme o caso. Os certificados de participação e os títulos de dívida poderão ser ao portador ou nominativos, endossáveis ou não, ou escriturais. Os certificados serão emitidos com base em um prospecto no qual constarão as condições de sua emissão, e conterá as informações necessárias para que se possa identificar o fideicomisso a que pertencem, com uma descrição sumária dos direitos conferidos. Os certificados de participação poderão ser emitidos em diversas classes e séries, podendo atribuir-se direitos diferentes para cada classe de certificados, mas dentro de uma mesma classe todos deverão ter iguais direitos.

No fideicomisso financeiro, em caso de insuficiência do patrimônio fideicomitido, se não houver previsão contratual, o fiduciário deverá convocar assembléia dos titulares de títulos de dívida, que deverá ser realizada dentro de 60 (sessenta) dias contados da última publicação do edital em jornal oficial e em jornal de grande circulação do domicílio do fiduciário, a fim de que a assembléia delibere sobre as regras de administração e liquidação do patrimônio. 
As referidas regras poderão prever: a) a transferência do patrimônio fideicomitido como unidade à outra sociedade de igual giro; b) as modificações do contrato de emissão, que poderão compreender a remissão de parte das dívidas ou a modificação dos prazos, modos ou condições iniciais; c) a continuação da administração dos bens fideicomitidos até a extinção do fideicomisso; d) a forma de alienação dos ativos do patrimônio fideicomitido; e) a designação daquele que terá a seu cargo a alienação do patrimônio como unidade ou dos ativos que os integram; f) qualquer outra matéria determinada pela assembléia referente à administração ou liquidação do patrimônio separado.

A assembléia se considerará validamente constituída quando estiverem presentes titulares de títulos que representem no mínimo $2 / 3$ do capital emitido e em circulação, os quais poderão fazer-se representar por meio de carta certificada por escrivão público, autoridade judicial ou banco, não sendo necessária a legalização. As deliberações deverão ser tomadas pelo voto favorável de detentores de títulos que representem, no mínimo, a maioria absoluta do capital emitido e em circulação, exceto nos casos de modificação do contrato de emissão em que a maioria será de $2 / 3$ dos títulos emitidos e em circulação. Se não houver quorum na primeira convocação, deverá ser realizada nova assembléia dentro dos 30 (trinta) dias seguintes, que será considerará validamente instalada com a presença dos detentores de títulos de dívidas que estiverem presentes na assembléia. As deliberações deverão ser tomadas com o voto favorável dos títulos que representem ao menos a maioria absoluta do capital emitido e em circulação. 


\section{CAPÍTULO II - NEGÓCIO FIDUCIÁRIO}

O presente capítulo trata do negócio fiduciário como forma de garantia. Primeiramente, será feita uma breve explanação sobre o entendimento doutrinário acerca do negócio jurídico. Depois, serão abordados os conceitos, sujeitos, objeto e estrutura do negócio fiduciário, bem como as espécies de negócios fiduciários adotados pela legislação brasileira.

\subsection{Negócio jurídico}

O negócio jurídico está disciplinado no Título I do Livro III - Dos Fatos Jurídicos da Lei no 10.406, de 10 de janeiro de 2002 (“Código Civil - CC”).

O Código Civil não traz uma definição do negócio jurídico, mas apresenta, tão somente, os seus requisitos de validade, sendo eles: agente capaz, objeto lícito, possível, determinado ou determinável, e forma prescrita ou não defesa em lei.

A doutrina atual, ao definir o negócio, adota geralmente uma posição que, ou se prende à sua gênese, ou à sua função; assim, ora o define como ato de vontade que visa produzir efeitos, com o que atende principalmente à formação do ato, à vontade que lhe dá origem (autonomia da vontade), ora o define como um preceito (dito até mesmo "norma jurídica concreta") que tira a sua validade da norma abstrata imediatamente superior, dentro de uma concepção escalonada de normas jurídicas supra e infra-ordenadas, com o que atende, principalmente, ao caráter juridicamente vinculante de seus efeitos (autoregramento da vontade). As próprias expressões autonomia da vontade e auto-regramento da vontade, apesar de aparentemente sinônimas, dão o sentido de ambas as concepções: a primeira, ligada ao momento inicial, à liberdade ("autonomia") para praticar o ato, e a segunda, ao momento final, aos efeitos ("regras") que do ato resultam. ${ }^{61}$

\footnotetext{
${ }^{61}$ Antônio Junqueira de Azevedo, Negócio Jurídico: Existência, Validade e Eficácia, p. 1.
} 
Orlando Gomes define o negócio jurídico como sendo toda declaração de vontade destinada à produção de efeitos jurídicos correspondentes ao intento prático do declarante, se reconhecido e garantido por lei. ${ }^{62} \mathrm{O}$ referido autor ensina que na sua formulação, os escritores se separam em três principais correntes: a voluntarista, a objetivista e a da autoresponsabilidade. ${ }^{63}$ Importante mencionar, no entanto, que Orlando Gomes só aborda em sua obra as duas primeiras correntes que serão abaixo descritas.

Para os defensores da tese voluntarista, o negócio jurídico é a declaração de vontade destinada a provocar determinados efeitos jurídicos, ou a ação da vontade que se dirige de acordo com a lei, a constituir, modificar ou extinguir uma relação jurídica. A concepção voluntarista suscita questões de grande interesse prático, consistindo a principal em saber se deve prevalecer a vontade real ou a declarada, se divergentes. Predomina a opinião de que o elemento verdadeiramente produtor dos efeitos jurídicos é a vontade real. Os opositores da teoria voluntarista negam à intenção o caráter de vontade propriamente dita, sustentando que o elemento produtor dos efeitos jurídicos é a declaração. ${ }^{64}$

Para os defensores da tese objetivista, o negócio jurídico é a expressão da autonomia privada, isto é, no poder de auto-regência dos interesses, que contém a enunciação de um preceito, independentemente do querer interno. $\mathrm{O}$ negócio jurídico seria "norma concreta estabelecida pelas partes". O poder de regulação dos particulares se exerce através de atos que vinculam os agentes a determinada conduta livremente traçada. $^{65}$ Segundo Orlando Gomes ${ }^{66}$, a teoria objetivista é muito criticada porque ela defende que do negócio jurídico nascem regras, quando é certo que somente pode gerar direitos e obrigações.

Após criticar as teorias voluntarista e objetivista, Antônio Junqueira de Azevedo ${ }^{67}$ propõe uma nova definição para o negócio jurídico com base em sua estrutura, podendo ser definido como categoria, isto é, como fato jurídico abstrato, ou como fato, isto é, como fato jurídico concreto. Como categoria, ele é a hipótese de fato jurídico (às vezes dita "suporte

\footnotetext{
${ }^{62}$ Introdução ao Direito Civil, $11^{\mathrm{a}}$ ed., 1995, p. 269.

${ }^{63}$ Ibid., p. 270 a 273.

${ }^{64}$ Ibid., p. 270 e 271.

${ }^{65}$ Ibid., p. 271.

${ }^{66}$ Ibid., p. 271.

${ }^{67}$ Antônio Junqueira de Azevedo, Negócio Jurídico: Existência, Validade e Eficácia, p. 16.
} 
fático"), que consiste em uma manifestação de vontade de certas circunstâncias (as circunstâncias negociais) que fazem com que socialmente essa manifestação seja vista como dirigida à produção de efeitos jurídicos. In concreto, negócio jurídico é todo fato jurídico consistente em declaração de vontade, a que o ordenamento jurídico atribui os efeitos designados como queridos, respeitados os pressupostos de existência, validade e eficácia impostos pela norma jurídica que sobre ele incide. ${ }^{68}$

Caio Mario da Silva Pereira ${ }^{69}$ entende que o negócio jurídico, nome dado pela moderna doutrina ao ato jurídico (stricto sensu), compreende a declaração de vontade dirigida no sentido da obtenção de um resultado. O negócio jurídico se distingue do ato jurídico, pois aquele é a declaração de vontade em que o agente persegue o efeito jurídico (Rechtesgeschäft), enquanto que no ato jurídico stricto sensu ocorre manifestação volitiva também, mas os efeitos jurídicos nascem da própria lei e são gerados independentemente de serem perseguidos diretamente pelo agente. Tanto negócio jurídico como ato jurídico stricto sensu estão compreendidos na grande categoria denominada "atos lícitos". Todo ato jurídico, portanto, se origina de uma emissão de vontade, mas nem toda declaração de vontade constitui um negócio jurídico.

Continua este autor dizendo que no negócio jurídico deve estar presente o supedâneo volitivo, consistente na declaração de vontade, através da qual se concretiza uma ação, ou um ato, mas este ato deve ser lícito, requisito resultante de sua confrontação com o ordenamento jurídico, e conseqüente subordinação do agente às imposições da lei. Mais ainda, no negócio jurídico há de estar presente uma finalidade jurídica, que o distingue do ato indiferente, ou de mera submissão passiva ao preceito legal, e que é encarecido como um dos seus extremos, assente na obtenção de um resultado efetivamente querido pelo agente. $^{70}$

Da mesma forma, Pontes de Miranda ${ }^{71}$ entende ser o negócio jurídico apenas uma das classes dos atos jurídicos em que há, como elemento fático, a manifestação da vontade.

\footnotetext{
${ }^{68}$ Antônio Junqueira de Azevedo, Negócio Jurídico: Existência, Validade e Eficácia, p. 16.

${ }^{69}$ Instituições de direito civil, v. 1, p. 303.

${ }^{70}$ Ibid., p. 305.

${ }^{71}$ Francisco Cavalcanti Pontes de Miranda. Tratado de Direito Privado, Parte Geral, Tomo III, p. 3.
} 
No mesmo sentido, Ennecerus ${ }^{72}$ define o negócio jurídico como sendo um suposto fático que contém uma ou mais declarações de vontade e que o ordenamento jurídico reconhece como base para produzir o efeito jurídico qualificado de efeito querido.

Segundo Orlando Gomes ${ }^{73}$, a função mais característica do negócio jurídico é, porém, servir de meio de atuação das pessoas na esfera de sua autonomia. É através dos negócios jurídicos que os particulares auto-regulam seus interesses, estatuindo as regras a que voluntariamente quiseram subordinar o próprio comportamento. Há, portanto, uma correlação entre o negócio jurídico e a autonomia privada, dizendo-se que se a autonomia privada é o poder de autodeterminação, o negócio jurídico é o instrumento através do qual o poder de autodeterminação se concretiza.

\subsection{Negócio fiduciário}

\subsubsection{Origem}

A hipoteca e penhor foram muito utilizados como garantia de obrigações. Todavia, eles apresentam o inconveniente de serem garantias de difícil execução em caso de inadimplemento do devedor, levando a doutrina moderna a estudar a criação de novas formas de garantia que melhor protegessem o crédito. Assim nasceu o negócio fiduciário que foi inspirado na fiducia cum creditore do direito romano, no penhor germânico e no trust anglo-americano.

O primeiro autor a tratar de negócio fiduciário foi Ferdinand Regelsberger, ${ }^{74}$ em sua obra Zwei Beiträge zur Lehre von der Cession de 1880, propondo a seguinte definição:

\footnotetext{
${ }^{72}$ Tratado de Derecho Civil, tomo I, v. II, 2a parte, trad. Blas Pérez Gonzáles e José Alguer, p. 56. ${ }^{73}$ Introdução ao Direito Civil, $11^{\mathrm{a}}$ ed., 1995, p. 264.

${ }^{74}$ A obra de Ferdinand Regelsberger é Zwei Beiträge zur Lehre von der Cession, in Archiv für die civilistische "Praxis", v. 63, págs. 157 e ss., apud Christoph Fabian. Fidúcia: negócios fiduciários e relações externas, p. 26 (tradução livre de: "Ich möchte für diese Rechtserscheinung die Bezeichnung fiduziarisches Geschäft vorschlagen, wöfur wir in den Quellen einen Vorgan haben”. Charakteristisch ist für dasselbe das Mißverhältnis zwischen Zweck und Mittel. Zur Erreichnung eines bestimmten Erfolgs wird eine Rechtsform gewählt, welche mehr gewährt, als zur Erzielung jenes Erfolgs erforderlich ist; zur Sicherung des Gebrauchs wird die Möglichkeit des Mißbrauchs in den Kauf genommen.")
} 
"Eu gostaria de propor para este fenômeno jurídico a denominação 'negócio jurídico' para o qual nós temos exemplos nas fontes. Característico é para este a desproporção entre finalidade e meio. Para alcançar um certo resultado, foi escolhida uma forma jurídica, que proporciona mais do que é necessário para se conseguir aquele resultado; para assegurar o uso toma-se em conta a possibilidade do abuso."

Regelsberger não define propriamente o que seria o negócio fiduciário, mas traça aquilo que considera como sua principal característica, qual seja, a incongruência ou heterogeneidade entre meio e fim.

Francesco Ferrara ${ }^{75}$ observa que o negócio fiduciário serve para tornar possível a realização de fins que a ordem jurídica não satisfaz, para atenuar certas durezas que não se compadecem com as exigências dos tempos, para facilitar e acelerar o movimento da atividade comercial. Aparece, pois, como um meio de completar o direito deficiente, de corrigir o direto inadequado, de produzir a evolução de novas formas jurídicas. Para conseguir os seus fins, os particulares não podem criar por seu próprio arbítrio tipos especiais de negócios, sendo obrigados a servir-se dos meios jurídicos existentes. O negócio fiduciário é, pois, o produto da combinação de várias formas jurídicas, muitas vezes contraditórias, combinadas e entrelaçadas de tal maneira que por intermédio delas se possa chegar a resultados novos.

\subsubsection{Conceito, Sujeitos, Objeto e Estrutura}

O negócio fiduciário de garantia pode ser definido como aquele em que uma parte, denominada fiduciante, transfere uma coisa ou direito à outra parte, denominada fiduciário, para fins de garantia de uma outra obrigação firmada entre fiduciante e fiduciário (ex. mútuo). Com a referida transferência, o fiduciário passa a ser o proprietário da coisa ou o titular pleno do direito, obrigando-se a destiná-lo conforme as instruções do fiduciante até o cumprimento da obrigação principal pelo fiduciante. Após o cumprimento da obrigação pelo fiduciante, o fiduciário compromete-se a restituir a coisa e/ou o direito ao fiduciante.

\footnotetext{
${ }^{75}$ A Simulação dos Negócios Jurídicos, trad. A. Bossa, p. 76 e 77.
} 
Para Melhim Namem Chalhub ${ }^{76}$, o negócio fiduciário é o negócio jurídico inominado pelo qual uma pessoa (fiduciante) transmite a propriedade de uma coisa ou a titularidade de um direito a outra (fiduciário), que se obriga a dar-lhe determinada destinação e, cumprido esse encargo, retransmitir a coisa ou direito ao fiduciário ou a um beneficiário indicado no pacto fiduciário.

Existem, portanto, três sujeitos no negócio fiduciário: (i) o fiduciante que é aquele que transmite a propriedade de uma coisa ou a titularidade de um direito em benefício próprio ou de terceiros; (ii) o fiduciário que é aquele que adquire a propriedade da coisa ou a titularidade de um direito e assume a obrigação de destiná-los ao cumprimento de determinada finalidade e, após seu cumprimento, restituí-los ao fiduciante ou a um beneficiário indicado pelo fiduciante; e (iii) o beneficiário que é indicado pelo fiduciante e aufere os proveitos da administração do bem, podendo receber os frutos da coisa ou a própria coisa.

Quanto ao objeto do negócio fiduciário deve ser ele determinado ou, pelo menos, determinável, podendo ser bem móvel ou imóvel, direito e coisas fungíveis ou infungíveis.

Otto de Souza Lima ${ }^{77}$ entende ser o negócio fiduciário aquele que em que se

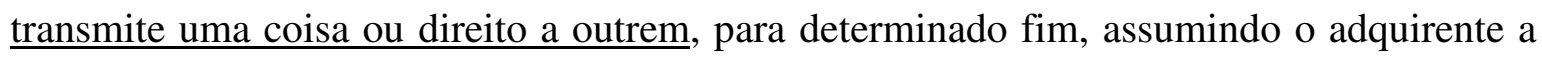
obrigação de usar deles segundo aquele fim e, satisfeito este, de devolvê-los ao transmitente.

Tulio Ascarelli ${ }^{78}$ nos ensina que:

"O característico do negócio fiduciário decorre do fato de se prender a ele a uma transmissão de propriedade, mas de ser, o seu efeito de direito real, parcialmente neutralizado por uma convenção entre as partes em virtude da qual o adquirente pode aproveitar-se da propriedade que adquiriu, apenas para o fim especial visado pelas partes, sendo obrigado a devolvê-la desde que aquele fim seja preenchido. Ao passo que os efeitos de direito real, isoladamente considerados e decorrentes do negócio adotado, vão além das intenções das partes, as ulteriores convenções obrigacionais visam justamente restabelecer o equilíbrio; e assim possível o uso da transferência da propriedade para finalidades indiretas (ou seja, para fins de

\footnotetext{
${ }^{76}$ Negócio Fiduciário, $4^{\mathrm{a}}$ ed., p. 32.

${ }_{77}^{77}$ Negócio Fiduciário, p. 170.

${ }^{78}$ Problemas das Sociedades Anônimas e Direito Comparado, p. 96 e 97.
} 
garantia, de mandato, de depósito). Mas os efeitos de direito real do negócio, são, eles também, queridos e seriamente queridos pelas partes, que, na falta deles, nem poderiam alcançar o fim ultimo visado; a realidade deste não contraria, mas pressupõe a do fim típico do negócio adotado. Assim, num caso típico de negócio fiduciário, a transferência da propriedade para fins de garantia, a transmissão da propriedade é efetivamente desejada pelas partes, não porém, para o fim de troca, mas para um fim de garantia."

Nicolo Lipari ${ }^{79}$ define o negócio fiduciário como sendo um ato de autonomia, manifestação de uma vontade seriamente querida, na qual um sujeito (fiduciante) investe outro (fiduciário) de uma posição jurídica cuja possível explicação de poder ou a potencialidade da forma jurídica escolhida excede o âmbito do resultado prático desejado, de forma que se acorda entre o contratante (pactum fiduciae) que quando investido utilizará a própria posição dentro de um limite particular de tempo ou de conteúdo, fazendo operar o mecanismo jurídico somente pela parte em que isso é necessário à satisfação do interesse do sujeito ou do interessado.

Andreas Von Tuhr ${ }^{80}$ entende que há negócio fiduciário quando se aliena um direito sem uma causa que justifique a aquisição definitiva por parte do destinatário, o qual, por essa razão, se obriga a restituí-lo se verificada certas circunstâncias. Desta maneira, o adquirente (fiduciário) assume frente ao alienante uma posição de confiança. A atribuição fiduciária pode ter por objeto a transferência da propriedade, a constituição ou transferência dos demais direitos reais (usufruto, obrigação imobiliária, etc.), a transferência de créditos ou direitos sobre coisas imateriais e a assunção de obrigações abstratas (em particular, o saque de uma letra de câmbio).

\footnotetext{
79 Il Negozio Fiduciario, p. 64 (tradução livre de: "il negozio fiduciario in quell'atto di autonomia, manifestazione di uma volontà seriamente indirizzata, con il qual um soggetto (fiduciante) investe altri (fiduciario) di uma posizione giuridica le cui possibili esplicazioni di potere ovvero le potenzialità della forma giuridica prescelta eccedono l'ambito del risultato pratico divisato, di guisa che si conviene fra $i$ contraenti (pactum fiduciae) che l'investito utilizzerà la própria posizione entro particolari limiti di tempo o di contenuto facendo operare il mecanismo giuridico solo per la parte in cui esso è necessário a soddisfare l'interesse del soggetto o dei soggetti interessati.")

${ }^{80}$ Derecho civil: teoría general del derecho civil alemán; traduzido do alemão para o espanhol por Tito Ravà, p. 210-211.
} 
Para Pontes de Miranda ${ }^{81}$ sempre que a transmissão tem um fim que não é a transmissão mesma, de modo que ela serve a negócio jurídico que não é o de alienação àquele a quem se transmite, diz-se que há fidúcia ou negócio jurídico fiduciário. Para ele, o fim fiducial pode ser o de garantia. Em vez de lançarem mão dos negócios jurídicos típicos de garantia (hipoteca, anticrese, penhor, caução de títulos, fiança), os declarantes ou manifestantes do negócio jurídico fiduciário para garantia utilizam atribuição patrimonial: em lugar de só hipotecar, anticretizar, empenhorar, ou caucionar, o que apenas criaria direito real de garantia, o fiduciante transfere ao credor a propriedade, para que, vencido o crédito, sem ser solvido, fique com a coisa, ou, solvido, a devolva. ${ }^{82}$

Álvaro Villaça Azevedo ${ }^{83}$ conceitua o negócio fiduciário como sendo o vínculo jurídico de natureza real, que se estabelece entre o fiduciante (tradens) e o fiduciário (accipiens), pelo qual o primeiro, que confia no segundo, transmite a este um direito ou bem jurídico, seja para garantir o pagamento de uma dívida ou para obter o favor da administração ou guarda de um patrimônio, tudo para que faça certo uso desse objeto fiduciário, dê a ele certo destino, e o restitua ao final do prazo (advento do termo), ou verificar-se uma condição (implemento da condição), sob pena de, descumprida essa obrigação, indenizar os prejuízos causados.

Ennecerus ${ }^{84}$ define o negócio fiduciário como sendo a transmissão de um direito para um fim (econômico) que não exige tal transmissão, por exemplo, a transmissão da propriedade para fins de administração ou para assegurar um crédito, cessão de um crédito ou endosso pleno de uma letra para sua cobrança.

Quanto à estrutura do negócio fiduciário, pode-se dizer que ele é formado por duas relações jurídicas entre fiduciante e fiduciário. A primeira relação jurídica é de natureza real e diz respeito à própria transmissão da propriedade do bem ou da titularidade de um direito do fiduciante ao fiduciário. Orlando Gomes, esclarece que esta primeira relação não

\footnotetext{
${ }^{81}$ Tratado de Direito Privado, tomo III, p. 115/116

${ }^{82}$ Ibid., p. 125 e 126.

${ }^{83}$ Alienação Fiduciária em Garantia de Bem Móvel e Imóve. In: Revista da Faculdade de Direito da Fundação Armando Álvares Penteado, ano 1, no 1 - 2002, p. 63.

${ }^{84}$ Tratado de Derecho Civil de Ennecerus, Kipp e Wolff, Tomo I, v. II, trad. de Blas Pérez González e José Alguer, p. 84 (tradução livre de: "LLámase negocio fiduciario a la transmisión de un derecho para un fin (económico) que no exige tal transmisión, por ejemplo, transmisión de la propriedad para fines de administración o para asegurar un crédito, cesión de un crédito o endoso pleno de una letra para su cobranza.”)
} 
se prende exclusivamente à transmissão de propriedade, porquanto o negócio translativo pode ter por objeto um direito de crédito (cessão fiduciária). ${ }^{85}$ A segunda relação jurídica é de caráter obrigacional, pois sujeita o fiduciário à obrigação de destinar o bem ou o direito transmitido para cumprir a finalidade de sua transmissão, obrigando-se a restituí-lo ao fiduciante após o seu cumprimento.

Feita a transmissão da propriedade do bem ou da titularidade do direito, o fiduciante não poderá reclamar o bem e/ou direito do fiduciário, pois o fiduciante tem apenas um direito de crédito contra ele. Como bem salienta Melhim Chalhub, em razão dessa dúplice constituição de direitos, a doutrina diverge quanto à estrutura do negócio fiduciário. $^{86}$

Para os defensores da tese dualista, também conhecida como teoria do duplo efeito, o negócio fiduciário seria uma estrutura complexa, composta de dois negócios, dois atos de natureza distinta, com a conjugação de dois contratos, quais sejam, um contrato real positivo, que tem como objeto a transferência normal do direito de propriedade ou do direito de crédito, e outro, contrato obrigatório negativo, pelo qual se estipula a obrigação do fiduciário de restituir a coisa, depois de cumprir a finalidade para a qual foi transmitida. Francisco Ferrara ${ }^{87}$, Giuseppe Messina ${ }^{88}$ é entre nós Orlando Gomes ${ }^{89}$ são defensores desta tese.

\footnotetext{
${ }^{85}$ Introdução ao Direito Civil, $11^{\text {a }}$ ed., 1995, p. 349.

${ }^{86}$ Melhim Namem Chalhub, Negócio Fiduciário, $4^{\mathrm{a}}$ ed., p. 41.

${ }^{87}$ Francesco Ferrara (A Simulação dos Negócios Jurídicos, trad. A. Bossa, 1939, p. 77 e 78 ) ensina que o negócio fiduciário é uma forma complexa que resulta da união de dois negócios de índole e efeitos diferentes, colocados em recíproca oposição. $1^{\circ}$ ) De um contrato real positivo, a transferência da propriedade ou do crédito que se realiza de forma perfeita e irrevogável; $2^{\circ}$ ) De um contrato obrigatório negativo, a obrigação do fiduciário de usar somente de certa forma do direito adquirido, para depois restituir ao transferente ou a um terceiro. Continua este autor, dizendo que os dois negócios, o real e o obrigatório, caminham paralelamente entre si e ficam de certo modo independentes, mesmo quando o segundo representa um constrangimento a não abusar da eficácia do primeiro.

${ }^{88}$ Scritti Giuridici, v.1, p. 119 (“Alla valutazione complessiva della sua natura giuridica ci è ora spianata la via da quanto s'è detto. Intanto tutte le concezioni unitarie della fidúcia naufragano nell'esposta indipendenza degli effeti dell'atto solenne translativo di proprietà da quelli del pactum conventum...”)

${ }^{89}$ Para Orlando Gomes (Introdução ao Direito Civil, $11^{\mathrm{a}}$ ed., 1995, p. 351), “o negócio fiduciário não é ato complexo, mas sim um complexo de negócios. O fato de se designá-lo como se fosse negócio do tipo unitário dá a falsa impressão de que se fundem as diversas declarações de que se compõe, descaracterizando-se para formar um só negócio. É verdade que a existência da causa fiduciae poderia ser invocada para atestar a unidade do negócio fiduciário, mas desde que os dois negócios, o translativo e o obrigacional, produzem efeitos próprios e independentes, conservariam sua individualidade. Consequientemente, seriam negócios conexos. No negócio fiduciário ocorreria o fenômeno da conexão de negócios. Dois negócios estariam unidos em uma relação de contemporaneidade para a consecução do mesmo resultado econômico-social ou prático jurídico. Tratar-se-ia de concurso de negócios. Os negócios concorrentes podem ser homogêneos ou heterogêneos. O negócio fiduciário pertenceria à categoria dos negócios concorrentes heterogêneos. $\mathrm{O}$
} 
Também é partidário da tese dualista, José Beleza dos Santos ${ }^{90}$ que, apesar de não admitir os negócios fiduciários no direito português, defende existir no ato fiduciário duas convenções distintas: uma positiva pela qual se transfere para outrem um direito real ou de crédito, transferência efetiva sob o ponto de vista jurídico e que coloca, portanto, o adquirente desse direito na situação de seu legítimo titular; outra que é o pacto fiduciário; convenção negativa, como lhe chama Goltz, pelo qual o adquirente (fiduciário) se obriga para com o transmitente (fiduciante) a fazer apenas certo e determinado uso do direito transmitido.

Federico de Castro y Bravo observa que a teoria do duplo efeito esbarrou em obstáculos, considerados intransponíveis por alguns escritores, notadamente, a justificação do direito do fiduciante na falência do fiduciário. Corrente ponderável inclinou-se para a tese que o direito do fiduciante, a despeito do pacto de fiducia, é simplesmente de crédito, não se justificando a separação do bem no processo falimentar. Outros escritores insurgiram-se contra o tratamento dispensado ao fiduciante pelos que queriam manter intransigente fidelidade à teoria do duplo efeito, entendendo alguns que se lhe deveria assegurar uma reivindicatio utilis, ou admitir que o abuso de confiança do fiduciário autorizaria a outra parte a reivindicar da massa falida o bem alienado fiduciariamente. Finalmente, o reconhecimento de que o fiduciário recebe sua titularidade com o fim limitado de legitimá-lo a atuar como verdadeiro titular trouxe reservas à teoria do duplo efeito, que concorreram para impulsionar o movimento de abandono dessa construção doutrinária. $^{91}$

Os defensores da tese monista ou unitária acreditam não se justificar o desmembramento do negócio em dois atos, pois, ao convencionar o negócio fiduciário, a vontade das partes é a de realizar um único negócio, que seria composto por duas partes, permeado pela causa fiduciae, da qual decorre efeitos reais, oponíveis erga omnes, e

concurso se daria entre negócios jurídicos diferentes, o translativo e o obrigacional, cada qual produzindo, verdadeiramente, seus efeitos peculiares. Pelo negócio translativo, a propriedade do bem se transfere do fiduciante para o fiduciário, qualquer que seja o título da transmissão uma vez que haja tradição ou transcrição. Pelo negócio obrigacional, o fiduciário contrai a obrigação de usar a coisa adquirida conforme a destinação que lhe foi dada, comprometendo-se, outrossim, a restituí-la logo seja preenchida a finalidade da transmissão. Portanto, dois negócios de índole e efeitos diferentes, colocados em oposição recíproca, mas coordenados ao mesmo fim. O nexo é objetivo, mas as causas dos dois negócios não se descaracterizariam para a formação de um só negócio com causa típica. A causa do negócio obrigacional, isto é, o pacto de fidúcia, não é a mesma do negócio translativo.”

${ }_{90}$ A simulação em direito civil, ps. 90 e 94.

${ }^{91}$ El negocio jurídico, p. 409 apud Orlando Gomes, Alienação fiduciária em garantia, 4ª ed., p. 25. 
efeitos obrigacionais, de alcance interno, cuja função seria contingenciar a eficácia real do contrato. Orlando de Carvalho ${ }^{92}$, Massimo Nuzzo ${ }^{93}$, Francesco Messineo ${ }^{94}$, Claudio Kiper e Silvio Lisoprawski ${ }^{95}$, Carlo Longo ${ }^{96}$, Pedro Pais de Vasconcelos ${ }^{97}$, Nicolo Lipari ${ }^{98}$ e Melhim Chalhub ${ }^{99}$ são defensores desta tese, da qual também somos partidários.

Francisco P. de Crescenzo Marino ${ }^{100}$ questiona se no negócio fiduciário deve haver necessariamente a transmissão de um direito do fiduciante ao fiduciário ou se bastaria que o primeiro efetuasse uma atribuição patrimonial em favor do segundo ${ }^{101}$. Em outras palavras: integraria o suporte fático do negócio jurídico fiduciário um negócio jurídico translativo, ou basta a presença de um negócio jurídico de atribuição patrimonial? Para ele, afigura-se mais correto considerar que o suporte fático do negócio jurídico fiduciário possa conter qualquer tipo de negócio jurídico de atribuição patrimonial, seja ele dispositivo (translativo, modificativo ou extintivo) ou obrigacional ${ }^{102}$. Ele entende que há negócio jurídico fiduciário sempre que uma parte (o fiduciante) efetua uma atribuição patrimonial em benefício de outra (o fiduciário), com um fim prático incongruente e mais restrito em relação à causa típica do negócio de atribuição patrimonial utilizado (fim esse tal como

92 Orlando de Carvalho. Negócio jurídico indireto. In: Boletim da Faculdade de Direito, Coimbra, suplemento X/1, 1952, p. 108 apud Judith Martins-Costa, Negócios Fiduciários - Considerações sobre a possibilidade de acolhimento do trust no Direito Brasileiro. In: Revista dos Tribunais, v. 657, p. 48, nota de rodapé 39.

${ }^{93}$ Massimo Nuzzo. Negozio fiduciario. In: Rivista di Diritto Civile 6/645, ano XXXI, nov e dez 1985, p. 648 apud Judith Martins-Costa, Negócios Fiduciários - Considerações sobre a possibilidade de acolhimento do trust no Direito Brasileiro. In: Revista dos Tribunais, v. 657, p. 41.

${ }^{94}$ Il contratto in genere, Tomo Secondo, p. 562.

${ }^{95}$ Tratado de Fideicomiso, p. 28.

${ }^{96}$ Corso di diritto romano, p. 55 ("Tutto cio non nuoceva all'unità del negozio fiduciario perchè $i$ suoi due elementi (reale e obbligatorio) erano collegati e resi inseparabili dall'identitá del loro obietto.")

${ }^{97}$ Contratos Atípicos, p. 259.

${ }^{98}$ Il Negozio Fiduciario, p. 271.

${ }^{99}$ Melhim Namem Chalhub, Negócio Fiduciário, 4 a ed., p. 42.

${ }^{100}$ Notas sobre o negócio jurídico fiduciário. In: Revista Trimestral de Direito Civil, v. 20, p. 36.

${ }^{101}$ Orlando Gomes (Introdução ao Direito Civil, 11 a ed., 1995, p. 337), ao classificar os negócios jurídicos pela causa da atribuição patrimonial, ensina que os negócios jurídicos patrimoniais distinguem-se pelo enriquecimento que, segundo a doutrina alemã, se chama atribuição (zuwindung), que consiste na vontade proporcionada ao patrimônio de outra pessoa. Implica, por conseguinte, alteração na esfera patrimonial de outrem, a troco de vantagem, ou sem recebimento de qualquer contraprestação. A atribuição patrimonial realiza-se para a consecução de determinado fim.

102 Orlando Gomes (Introdução ao Direito Civil, $11^{\text {a }}$ ed., 1995, p. 332 e 333) ensina que o negócio obrigacional é aquele cujo conteúdo é preenchido por obrigações assumidas pelas duas ou por uma das partes. O referido autor distingue os negócios dispositivos dos negócios obrigacionais argumentando que eles são meios de atuação jurídica distintos porque constituem instrumentos para o exercício da atividade econômica, que se processa através da disposição dos bens ou do aproveitamento de atos exigíveis de outra pessoa. Quando essa atividade requer o deslocamento de um bem como outro patrimônio, o instrumento jurídico próprio é o negócio dispositivo. Quanto consiste em vantagem a ser obtida na ação ou omissão de outra pessoa, o meio hábil é o negócio obrigacional. Na maioria das vezes, o negócios dispositivo completa o negócio obrigacional. 
garantia, cobrança de dívida, administração ou custódia de bens, etc.), estipulando as partes, em virtude dessa incongruência, a obrigação de o fiduciário exercer a posição jurídica que lhe cabe em virtude do negócio de atribuição patrimonial em conformidade com o fim visado. Normalmente, o fiduciário obriga-se ainda a restituir ao fiduciante o bem que lhe foi atribuído (se for esse o caso) ou a atribuí-lo a outrem, uma vez desaparecida a razão da atribuição patrimonial (por exemplo, quando for paga pelo fiduciante a dívida que o negócio busca garantir). ${ }^{103}$

Em que pese a opinião acima, não parece razoável conceber-se que o suporte fático do negócio fiduciário possa conter qualquer tipo de negócio jurídico de atribuição patrimonial, uma vez que no negócio fiduciário não há "enriquecimento do patrimônio alheio", que é um dos requisitos da atribuição patrimonial. Como bem anota Francesco Ferrara $^{104}$, o patrimônio do fiduciário parece ter aumentado, quando, na realidade, por efeito da obrigação negativa que neutraliza o da transferência, permanece como estava. Mais ainda, no negócio fiduciário há necessariamente um negócio de disposição translativo com a transferência de um bem ou direito do patrimônio do fiduciante ao fiduciário.

\subsubsection{Incongruência ou Heterogeneidade entre Meio e Fim}

Como já anotado por Regelsberger, uma das características do negócio fiduciário é a incongruência ou heterogeneidade entre o escopo desejado pelas partes e o meio utilizado para atingi-lo.

Orlando Gomes ${ }^{105}$ salienta que o negócio fiduciário caracteriza-se pela transcendência do meio sobre o fim. Entre o fim visado pelas partes e o meio utilizado para alcançá-lo não há congruência. Desdobra-se em fases, a que correspondem negócios realmente queridos pelas partes. Na primeira, efetua-se a transmissão, séria, verdadeira, de um direito de fiduciante. Na segunda, cumpre-se a obrigação do fiduciário de restituir o que recebeu, ou seu equivalente. Esses dois momentos são essenciais à configuração do negócio fiduciário.

\footnotetext{
${ }^{103}$ Notas sobre o negócio jurídico fiduciário. In: Revista Trimestral de Direito Civil, v. 20, p. 39.

${ }^{104}$ A Simulação dos Negócios Jurídicos, trad. A. Bossa, p. 80.

${ }^{105}$ Introdução ao Direito Civil, $11^{\mathrm{a}}$ ed., 1995, p. 348.
} 
No mesmo sentido, Francesco Ferrara ${ }^{106}$ entende que há uma contradição entre o fim e o meio empregado, pois usa-se um meio mais forte para obter um resultado mais fraco, emprega-se uma forma jurídica mais importante para obter um efeito menor. A essência do negócio fiduciário vai mais além da finalidade das partes, que supera a intenção prática, que tem mais conseqüências jurídicas do que as seriam necessárias para se alcançar o fim em vista.

Para Cariota-Ferrara ${ }^{107}$, o negócio jurídico fiduciário é caracterizado pelo excesso do meio adotado em face do escopo que se quer conseguir: uma parte (fiduciante) para uma finalidade restrita dá amplo poder jurídico à outra parte (fiduciário), que assume a obrigação (pessoal) de usar dessa posição jurídica de natureza real, constitutiva, somente dentro e nos limites da sua finalidade.

A característica essencial do negócio fiduciário é o fato de que o meio jurídico utilizado sempre extravasa o resultado econômico objetivado, registrando-se, aí, a presença da fidúcia, vale dizer, a confiança em que o fiduciário, tendo recebido um poder jurídico formalmente ilimitado sobre a coisa que lhe foi transmitida, dele não fará uso senão para atender à finalidade definida no contrato celebrado entre ele e o fiduciante. ${ }^{108}$

Pela definição de negócio fiduciário feita por Nicola Coviello ${ }^{109}$, acrescenta-se mais um elemento à configuração do negócio fiduciário que é a ausência de aumento de patrimônio. Assim diz ele: "efetivamente, não se visa, com o negócio fiduciário, o aumento do patrimônio do adquirente. A transferência que se faz visa a outro fim que não aquele aumento. Se o visasse, confundir-se-ia o negócio fiduciário com o próprio meio usado."

\footnotetext{
${ }^{106}$ Ibid., p. 78.

107 I Negozi Fiduciari, p. 1 (tradução livre de: "I negozi giuridici fiduciari sono caratterizzati da un'eccedenza del mezzo adoperato di fronte allo scopo che si vuol conseguire: una parte (fiduciante) per un fine ristretto dà un ampio potere giuridico all'altra (fiduciario) che assume l'obbligo (personale) di usare della posizione giuridica reale, costituitale, solo entro i limiti di quel fine.")

${ }^{108}$ Melhim Namem Chalhub. Negócio Fiduciário, $4^{\mathrm{a}}$ ed., p. 38.

${ }^{109}$ Manuale di Diritto Civile Italiano, v. 1, p. 355.
} 
No mesmo sentido, J.M. de Carvalho Santos $^{110}$ entende que a característica do negócio fiduciário é o fato de não produzir o efeito de aumentar o patrimônio do adquirente, uma vez que a relação obrigacional negativa força naturalmente essa conseqüência. Do mesmo modo, Melhim Chalhub observa que a transmissão fiduciária nada acresce ao patrimônio do fiduciário, pois essa modalidade de transmissão não tem como causa a troca de uma coisa pelo seu equivalente em dinheiro, mas apenas constitui um veículo para consecução de outros negócios. ${ }^{111}$

\subsubsection{A Causa nos Negócios Fiduciários}

Como já explicado no item 2.2.2 da presente dissertação, a doutrina diverge quanto à estrutura do negócio fiduciário. Os partidários da tese dualista entendem que o negócio fiduciário é composto por dois negócios, sendo um de natureza real e outro de natureza obrigacional (pactum fiduciae), defendendo que cada um deles teria causa própria, não se descaracterizando para a formação de um só negócio com causa típica. Portanto, para os partidários da tese dualista não existe uma causa única no negócio fiduciário. Por outro lado, os partidários da tese monista ou unitária defendem que não se justifica o desmembramento do negócio fiduciário em dois atos, pois a vontade das partes é a realização de um único negócio. Assim, portanto, para os partidário da tese monista o negócio fiduciário possui uma única causa.

Feitas as considerações acima sobre a divergência doutrinária quanto à estrutura do negócio fiduciário, ainda resta saber se os negócio fiduciários podem ser considerados negócios causais ou negócios abstratos. ${ }^{112}$

\footnotetext{
${ }^{110}$ Código Civil Brasileiro Interpretado, v. II, p. 386.

111 Propriedade Fiduciária de Bens Móveis em Garantia. In: Revista de Direito Bancário e de Mercado de Capitais, ano 6, nº 21, jul-set 2003, p. 309.

112 Orlando Gomes (Instituições de Direito Civil, $11^{\text {a }}$ ed., 1995, p. 338-340) ensina que a atribuição patrimonial realiza-se para a consecução de determinado fim. Quem delibera desfazer-se de um bem, deslocando-o para o patrimônio de outra pessoa, tem em mira alcançar algum resultado. Assim, a causa de atribuição patrimonial é a finalidade usual (típica) do comércio jurídico que se visa a alcançar com a atribuição. As três principais causas de atribuição patrimonial são: a causa adquirendi, a causa solvendi e a causa donandi. Continua ele dizendo que os negócios causais são os que exigem a causa de atribuição patrimonial como requisito necessário à validade da obrigação contratual. Aos negócios causais contrampõese os negócios abstratos, assim definidos como sendo aqueles em que a causa de atribuição patrimonial é abstraída pelo ordenamento jurídico. No negócio abstrato, a causa não é levada em conta como elemento do negócio contido na atribuição. Por fim, esclarece que entre nós não se admitem negócios abstratos puros.
} 
Alguns doutrinadores defendem a posição de que os negócios fiduciários são causais, sendo que a causa do negócio pode ser encontrada no contrato obrigatório entre fiduciante e fiduciário (pactum fiduciae). São eles Navarro Martorel1 ${ }^{113}$, Álvaro Villaça Azevedo $^{114}$, dentre outros. Por outro lado, Cariota-Ferrara defende que o negócio fiduciário é abstrato, pois consiste em uma transmissão abstrata, pura e simples, de um direito (de propriedade ou de crédito), com um fim (de garantia ou de mandato). ${ }^{115}$ No mesmo sentido Messina $^{116}$.

\subsubsection{Relações Internas e Externas no Negócio Fiduciário}

A doutrina formulou algumas teorias acerca da situação jurídica do fiduciante e fiduciário nas suas relações internas e nas suas relações com terceiros.

José Beleza dos Santos destaca a teoria da propriedade dividida ou mitigada (Theorie des geteilten Eigentums) e a teoria da transmissão completa da propriedade ou transmissão plena do direito (Theorie des vollen Eigentumsüberganges, Theorie der vollen Rechtsübertragung) que serão melhor detalhadas abaixo:

Para os defensores da teoria da propriedade dividida ou mitigada torna-se necessário distinguir no ato fiduciário as relações externas do fiduciante e fiduciário com terceiros estranhos ao pacto fiduciário, das relações internas, isto é, entre o fiduciante e o fiduciário. Para terceiros vale unicamente a convenção pela qual se transmitiu o direito real ou de crédito para o fiduciário e só este é o titular desse direito transmitido. Entre o fiduciante e o fiduciário prevalece, porém, a situação criada pelo pacto fiduciário e o adquirente será apenas credor, se se tratar de um ato fiduciário de garantia, e mandatário se a restrição, estabelecida pelo pacto fiduciário, o reduz a essa situação jurídica. (Ex. endosso para simples cobrança - o fiduciário será para terceiros um verdadeiro endossado, mas na relação interna com o fiduciante, ele será unicamente mandatário. Se o fiduciário

Todos os negócios translativos são causais e, até nos títulos de crédito, apontados geralmente como negócios abstratos, a abstração da causa é relativa.

${ }^{113}$ La Propriedad Fiduciaria, p. 109.

${ }^{114}$ Contratos Inominados ou Atípicos e Negócio Fiduciário, p. 131

${ }^{115}$ I Negozi Fiduciari, pp. 78-97.

${ }^{116}$ Scriti Giuridici,v. 1, pp. 111 e 112. 
abusar dessa condição, retendo indevidamente em seu poder a coisa que lhe foi transmitida, poderá o fiduciante reivindicá-la exigindo sua restituição nos termos do pacto fiduciário. Se for declarada a falência do fiduciário, o fiduciante pode reclamar à massa falida a entrega daquilo que só fiduciariamente transmitiu).

Já para os defensores da teoria da transmissão completa da propriedade ou transmissão plena do direito, ainda que o fiduciário não cumpra a convenção negativa pela qual se obriga a fazer apenas um certo uso dos poderes que lhe são conferidos, ainda que abuse da confiança que nele depositou o fiduciante, nunca este poderá reivindicar a coisa alienada do poder do adquirente, nem de terceiros, nem exercer qualquer direito como titular do crédito que fiduciariamente tenha alienado. Neste caso de abuso do fiduciário, de não cumprimento da convenção negativa, resta ao fiduciante unicamente o direito de exigir a respectiva indenização por perdas e danos ao fiduciário e mesmo ao terceiro subadquirente, quando este tenha procedido com dolo e má-fé. Se for declarada a falência do fiduciário, segundo a teoria da transmissão completa do direito, o fiduciante não poderá reclamar a restituição do objeto transmitido fiduciariamente, porque essa restituição só pode exigir-se quando diga respeito a coisas de que o reclamante seja legítimo dono e o falido mero detentor (Código de Processo Comercial, art. 243, n.1) e, neste caso, o legítimo dono da coisa é o falido, para quem o fiduciante o transmitiu. Este transmitente será apenas um credor do falido pelo não cumprimento do pacto fiduciário. (grifos nossos $)^{117}$

Ferrara defende a teoria da transmissão plena do direito, sob o argumento de que o negócio fiduciário produz a transferência plena e absoluta do direito: a finalidade limitada para a qual se realiza não limita juridicamente a disposição. O fiduciário torna-se proprietário e credor perante todos e pode usar como entender oportuno do direito adquirido. $^{118}$

Essas teorias têm especial relevo no estudo do tratamento a ser dado ao bem transmitido fiduciariamente na hipótese de falência do credor-fiduciário, pois enquanto pela teoria da propriedade dividida ou mitigada o devedor-fiduciário tem direito de pleitear a restituição do bem que só fiduciariamente transmitiu ao credor-fiduciário, para a teoria da

\footnotetext{
${ }_{117}^{117}$ José Beleza dos Santos, A Simulação em Direito Civil, pp. 91 e 92.

${ }^{118}$ A simulação em negócio jurídico, trad. A. Bossa, 1939, p. 85.
} 
transmissão plena do bem o devedor-fiduciário tem apenas um direito de crédito em relação ao credor-fiduciário.

\subsection{Distinção entre Negócio Fiduciário e Negócio Indireto}

Foram os doutrinadores alemães os primeiros a tratar do negócio indireto. Ihering demonstrou que alguns negócios antigos, diretos, aplicavam-se a fins distintos dos primitivos. Em 1878, Kohler distinguiu o negócio jurídico indireto - por ele denominado verdeckte Geschäft (negócio encoberto) - do negócio jurídico simulado, desfazendo o equívoco de Ihering, que considerava aquele mero desdobramento deste. ${ }^{119}$

Também a doutrina italiana ocupou-se da matéria, sendo que Francesco Ferrara e Giuseppe Messina adotaram o termo "negócio indireto". Já Ascarelli preferiu chamá-lo de negócio com fim indireto ${ }^{120}$.

Com efeito, o negócio jurídico se diz indireto quando as partes recorrem a um negócio jurídico típico, sujeitando-se à sua disciplina formal e substancial, para alcançar um fim prático ulterior (o escopo de garantia, que é motivo, e não causa), o qual não é o normalmente atingido por meio desse negócio. Assim, a compra e venda tem como causa a troca de coisa por dinheiro, e como escopo último (motivo) qualquer utilização da coisa pelo comprador como proprietário; já a compra e venda com fim de garantia (negócio jurídico indireto) é uma compra e venda (negócio jurídico típico) em que a causa é a desta (troca de coisa por dinheiro), mas em que o escopo último (motivo) não é aquele a que normalmente se visa quando se celebra uma compra e venda (qualquer utilização da coisa pelo comprador como proprietário), mas o de a coisa adquirida servir ao seu proprietário como garantia do pagamento de crédito. ${ }^{121}$

\footnotetext{
${ }^{119}$ José Carlos Moreira Alves, Da Alienação Fiduciária em Garantia, p. 4.

${ }^{120}$ Tulio Ascarelli, Problemas das Sociedades Anônimas no Direito Comparado, p. 94, nota 6.

${ }^{121}$ José Carlos Moreira Alves, Da Alienação Fiduciária em Garantia, p. 6, nota 11. No mesmo sentido, Tulio Ascarelli (Negócio Jurídico Indirecto, p. 10) diz que "há negócio indireto, quando as partes recorrem no caso concreto a um negócio determinado, para atingir através dele, consciente e consensualmente, fins diversos dos típicos da estrutura do negócio adotado."
} 
O fim ulterior do negócio indireto pode constituir um verdadeiro negócio jurídico: assim, a compra e venda com fins de mandato ou de garantia; venda, permuta ou transação entre co-herdeiros com fins de divisão. Outras vezes o fim ulterior consistirá num mero resultado jurídico diferente: assim, a aquisição de um crédito ou a assunção de uma dívida com fins de compensação; a escolha de um domicílio social em lugar diferente do originário com o objetivo de desfrutar de um tratamento jurídico diferente. ${ }^{122}$

A doutrina formulou três teorias acerca do negócio indireto e do negócio fiduciário. A primeira teoria sustenta que os negócios fiduciários estão compreendidos dentro do gênero negócios indiretos. São defensores desta tese, dentre outros, Cariota-Ferrara ${ }^{123}$, Ascarelli $^{124}$ e Ferrara ${ }^{125}$. A segunda teoria defende que os negócios indiretos identificamse, perfeitamente, com os fiduciários. Defendem esta tese: Regelsberger ${ }^{126}$ e Wulff $^{127}$, os quais entendem que só integram a categoria de negócios indiretos os negócios fiduciários. A terceira teoria nega a categoria autônoma dos negócios indiretos, sem identificá-los, entretanto, com os fiduciários. São defensores desta teoria Graziani ${ }^{128}$ e Grassetti ${ }^{129}$. Já Santoro-Passarelli ${ }^{130}$ e Dominedò ${ }^{131}$ consideram que não existe a categoria autônoma de negócios indiretos, somente existindo os negócios fiduciários como categoria independente.

Martorell, mesmo aceitando as considerações feitas por Graziani e Grassetti, entende que embora os negócios indiretos não possuam uma estrutura especial que os diferenciem como gênero dos mesmos negócios quando empregados diretamente, eles existem. Martorell entende que poderiam ser negócios indiretos em sentido amplo todos aqueles que não são diretos, isto é, que não são utilizados direta e simplesmente para o seu fim típico. Nesse sentido, os negócios indiretos não constituiriam uma categoria jurídica.

\footnotetext{
${ }^{122}$ Custódio da Piedade Ubaldino Miranda. Negócio Jurídico Indireto e Negócios Fiduciários. In: Revista de Direito Civil Imobiliário, Agrário e Empresarial - ano 8 - jul/set 1984, p. 82.

${ }^{123}$ I Negozi Fiduciari, p. 39.

${ }^{124}$ O Negócio Jurídico Indirecto, p. 13.

${ }^{125}$ A Simulação dos Negócios Jurídicos, trad. A. Bossa, 1939, p. 77.

${ }^{126}$ Zwei Beiträge zur Lehre von der Cession, in Archiv für die civilistische "Praxis", v. 63, p. 173, n. 7 apud Navarro Martorell, Propriedad Fiduciária, p. 134.

${ }^{127}$ Das Vollindossamen zu Incassozcwecken, p. 24 apud Navarro Martorell, Propriedad Fiduciária, p. 134.

${ }^{128}$ Negozi indiretti e negozi fiduciari. In: Revista de Diritto Commerciale, 1933, I, p. 414 apud Navarro Martorell, Propriedad Fiduciária, p. 136.

${ }^{129}$ Donazione Fiduciaria, p. 362 apud Navarro Martorell, Propriedad Fiduciária, p. 138.

${ }^{130}$ Interposizione di persona, negozio indiretto e successione della prole adulterina in Foro italiano, 1932, I, p. 176 e ss. apud Navarro Martorell, Propriedad Fiduciária, p. 134.

${ }^{131}$ La costituzione fitizzia delle anonime, p. 693-694 apud Navarro Martorell, Propriedad Fiduciária, p. 134.
} 
Todavia, se dentro deste amplo grupo formado por exclusão, se quer ainda determinar uma categoria especial com aqueles negócios caracterizados por serem seriamente queridos, mas que têm um motivo que intencionalmente supera o fim próprio do negócio sem que exista desproporção entre este como meio e aquele como fim, então se estará falando de negócios indiretos em sentido estrito, cuja impossibilidade de serem caracterizados como categoria dogmática deriva-se da irrelevância normal dos motivos. Os negócios indiretos são diferentes dos negócios fiduciários não somente pela falta de desproporção, do excesso do meio sobre o fim, como também pela qualidade de serem causais. ${ }^{132}$

\subsection{Distinção entre Negócio Fiduciário e Negócio Simulado}

O negócio fiduciário é freqüentemente confundido com negócio simulado, havendo autores que negam mesmo a possibilidade ou a utilidade de diferenciá-los. Simular significa fazer aparecer o que não é, mostrar uma coisa que realmente não existe. Simular é fazer similar, dar aspecto e semelhança ao não verdadeiro. ${ }^{133}$

Para Ferrara ${ }^{134}$, negócio simulado é o que tem uma aparência contrária à realidade, ou porque não existe em absoluto ou porque é diferente da sua aparência. Entre a forma extrínseca e a essência íntima há um contraste flagrante: o negócio que, aparentemente, é sério e eficaz, é, em si, mentiroso e fictício, ou constitui uma máscara para ocultar um negócio diferente. Esse negócio, pois, é destinado a provocar uma ilusão no público, que é levado a acreditar na sua existência ou na sua natureza, tal como aparece declarada, quando, na verdade, ou não se realizou um negócio ou se realizou outro diferente do expresso no contrato. Todavia, Ferrara ${ }^{135}$ entende que deve-se fazer distinção entre negócios simulados e negócios fiduciários, já que estes últimos são sérios e efetivam-se realmente entre as partes com o fim de obter um efeito prático determinado. Os contratantes querem o negócio com todas as suas consequiências jurídicas, ainda que se sirvam dele para uma finalidade econômica diversa. Assim, por exemplo, a transmissão de

\footnotetext{
${ }^{132}$ La Propriedad Fiduciaria, p. 138.

${ }^{133}$ Francesco Ferrara, A Simulação dos Negócios Jurídicos, trad. A. Bossa, 1939, p. 49.

${ }^{134}$ Ibid., p. 51.

${ }^{135}$ Ibid., p. 76.
} 
propriedade para fins de garantia, a cessão de crédito tendo em vista o mandato, o endosso total para fins de recebimento.

José Beleza dos Santos ${ }^{136}$ entende não ser lícito confundir os atos fiduciários com os simulados. Nos primeiros, não existe, ao contrário do que se dá nos segundos, uma divergência entre a vontade real e a declarada com o intuito de enganar terceiros. A vontade manifesta-se neles tal qual é: quer-se realizar a transmissão de um direito real ou de um crédito, mas que o adquirente não use do direito transmitido, senão para um certo fim. Não há, portanto, uma vontade aparente divergindo de uma vontade real. A contradição que no ato fiduciário aparece entre a sua causa e seus efeitos jurídicos não é dissimulada, mas claramente revelada pelo ato jurídico. Não se pretende enganar terceiros, e pelo contrário, acautelam-se inteiramente os seus direitos, porque o pacto fiduciário não os interessa nem tem efeitos para eles, regula apenas as relações entre as próprias partes.

Pedro Pais de Vasconcelos ${ }^{137}$ distingue o negócio fiduciário do negócio simulado pela modificação que as partes geram na ordem jurídica. No contrato relativamente simulado, é o contrato dissimulado que é posto em vigor embora sob a aparência do contrato simulado. No contrato fiduciário, o que se passa é diferente. A situação jurídica em que o fiduciário é investido e o ato que opera a investidura são efetivamente postos em vigor e ganham vigência no Direito. Na simulação, o contrato simulado é criador de aparência; na fidúcia, o tipo adotado investe o fiduciário na titularidade.

Portanto, o negócio simulado não se confunde com o negócio fiduciário, pois neste último as partes desejam o resultado produzido, não havendo, portanto, discrepância entre a vontade das partes e os efeitos produzidos pelo negócio.

\subsection{Espécies de Negócio Fiduciário no Brasil}

Como bem salienta José Carlos Moreira Alves ${ }^{138}$, em nosso país, o negócio jurídico fiduciário e o negócio jurídico indireto eram, até não há muito, de escasso uso prático, e na

\footnotetext{
${ }^{136}$ A Simulação em Direito Civil, pp. 111 e 112.

${ }^{137}$ Contratos Atípicos, p. 300.

${ }^{138}$ Da Alienação Fiduciária em Garantia, p. 5.
} 
doutrina raro o autor que deles se ocupava. Pode-se dizer que passou despercebida, no Brasil, a controvérsia que, notadamente no início deste século, agitou os juristas alemães e italianos sobre a validade desses meios indiretos de garantia, por intermédio da transmissão da propriedade mobiliária ou imobiliária. E despercebida não apenas dos juristas, mas também dos Tribunais, indício seguro da escassa utilização prática dessas modalidades de negócio jurídico.

A primeira tentativa de introduzir o fideicomisso "inter vivos" no sistema legislativo brasileiro foi feita por Teixeira de Freitas no Esboço do Código Civil. No capítulo da doação, artigo 2.145, previa-se a doação com substituição direta nos seguintes termos: "é a que se faz nomeando-se uma ou mais pessoas para em conjunto ou gradualmente aceitarem a doação, no caso de não querer ou não poder o donatário aceitá-la”. O artigo 2.146 tratava da doação com substituição fideicomissária, definida como sendo a "que se faz com o encargo de restituir o donatário a um terceiro os bens doados, cumprida que seja uma condição, ou depois de um vencimento de um prazo." O artigo 2.147 determinava que seriam reguladas, em tudo o que fosse aplicável, pelo que se dispusesse a respeito da substituição dos herdeiros e legatários, sendo as doações fideicomissárias proibidas nos mesmos casos em que forem proibidos os outros fideicomissos. No artigo 2.154 estipulava-se que aceita a doação pelo fiduciário e notificada ao doador, poderiam eles, de comum acordo, fazer no fideicomisso as alterações que quisessem, podendo até substituir o fideicomissário ou mesmo revogar o fideicomisso, sem que a isso pudesse se opor o fideicomissário. Todavia, nem o Código Civil de 1916 nem o atual Código Civil adotaram o fideicomisso "inter vivos" por meio de doação com substituição direta ou doação com substituição fideicomissária. ${ }^{139}$

Uma segunda tentativa de se regular a fidúcia no Brasil foi por meio do Projeto de Lei $\mathrm{n}^{\circ} 3.362$, de 14.10.1957, de autoria do deputado Elias Adaime (PTB/SC) que previa o "fideicomisso inter vivos" e tipificava um negócio denominado administração fiduciária que era reservado às instituições financeiras.

${ }^{139}$ Augusto Teixeira de Freitas, Esboço do Código Civil, 2 v., pp. 382 e 383. 
Posteriormente, o Projeto de Código de Obrigações de 1965, cuja Comissão Revisora era composta por Orosimbo Nonato (Presidente), Caio Mario da Silva Pereira (Relator-Geral), Theophilo de Azeredo Santos, Sylvio Marcondes, Orlando Gomes, Nehemias Gueiros e Francisco Luiz Cavalcanti Horta (Secretário), dedicou um capítulo inteiro à fidúcia ${ }^{140}$.

No relatório de apresentação do Projeto, Caio Mario da Silva Pereira explica que pela fidúcia, que teve ingresso no Projeto por proposta de Nehemias Gueiros e redação deste e de Caio Mario e Orlando Gomes, ingressa em nosso direito o trust angloamericano, em razão dos bons resultados que apresentava naqueles sistemas jurídicos ${ }^{141}$.

O contrato de fidúcia foi definido no artigo 672 do Projeto da seguinte forma:

"Pelo contrato de fidúcia uma das partes, recebendo da outra bens móveis ou imóveis, assume o encargo de administrá-los em proveito do instituidor ou de terceiros, tendo, porém, a livre disposição dos mesmos, sem prejuízo do direito do beneficiário."

O contrato de fidúcia também exigia forma escrita e poderia ser constituída sobre bens e direitos presentes ou futuros, em caráter revogável ou irrevogável. Quando a fidúcia tivesse por objeto bens imóveis, o contrato deveria ser registrado no Registro de Imóveis e, com o registro, o bem imóvel transferido ao fiduciário constituir-se-ia propriedade resolúvel. Os bens objeto da fidúcia constituiriam patrimônio separado e deveriam ser administrados de acordo com as instruções prescritas pelo instituidor e, na falta destes, com a diligência do homem de negócio leal e honesto. As instituições financeiras poderiam manter, sob autorização do órgão competente do Governo Federal, um serviço de administração de bens mediante contrato de fidúcia.

\footnotetext{
${ }^{140}$ Projeto de Código de Obrigações. Comissão de Estudos Legislativos do Ministério da Justiça e Negócios Interiores, publicado pelo Serviço de Reforma de Códigos, 1965.

${ }^{141}$ Ibid., p. 22.
} 
A fidúcia poderia ser extinta por: (i) revogação, prevista expressamente; (ii) vencimento do prazo ajustado, quando não vitalícia; e (iii) renúncia ou morte do beneficiário, sem sucessor indicado pelo instituidor. Extinta a fidúcia, os bens reverteriam de pleno direito ao instituidor ou seus sucessores, exceto se houvesse previsão contratual expressa para a consolidação da propriedade no patrimônio do beneficiário.

Embora o Anteprojeto não tenha prosperado, houve paulatinamente a introdução em nosso ordenamento jurídico de leis esparsas admitindo certas modalidades de negócios fiduciários, tais como: (i) a alienação fiduciária em garantia de bens móveis que está regulada no artigo 66-B da Lei de Mercado de Capitais, com a redação dada pela Lei $\mathrm{n}^{\circ}$ 10.931, de 02.08.2004; (ii) a alienação fiduciária em garantia de bens imóveis introduzida pela LSFI; (iii) a alienação fiduciária de ações, partes beneficiárias e bônus de subscrição, prevista no artigo 40 da Lei das Sociedades por Ações; (iv) a cessão fiduciária de direitos sobre coisas móveis, bem como de títulos de crédito introduzida no artigo 66-B da Lei de Mercado de Capitais, com a redação dada pela Lei $n^{\circ} 10.931$, de 02.08.2004; dentre outras. Por fim, importante mencionar que o Código Civil de 2002 inseriu a propriedade fiduciária nos artigos 1.361 a 1.368 na parte relativa ao Direito das Coisas.

Com o advento da tipificação de algumas modalidades de negócio fiduciário, verificou-se uma mudança na prática bancária e imobiliária que deixou de utilizar as tradicionais garantias (hipoteca e penhor) e passou a utilizar os negócios fiduciários de garantia.

Nos próximos subitens serão abordadas, de forma sumária, apenas as principais espécies de negócios fiduciários de garantia, tais como: venda com escopo de garantia, propriedade fiduciária, alienação fiduciária de bens móveis e imóveis, alienação fiduciária de ações, partes beneficiárias e bônus de subscrição e, por fim, a cessão fiduciária de créditos. Não serão abordados os negócios fiduciários de administração (gestão), nem os negócios fiduciários de cobrança, já que não estão compreendidos no escopo da presente dissertação. 


\subsubsection{Venda com Escopo de Garantia}

A venda com escopo de garantia constitui a primeira forma típica de negócio fiduciário de garantia. Consiste na transmissão da propriedade de uma coisa ao credor, que recebe tal direito unicamente para segurança de seu crédito, isto é, para poder satisfazer-se, eventualmente, por falta de pagamento, mas com a obrigação de restituir a coisa recebida uma vez satisfeita. O credor torna-se proprietário da coisa, mas deve usar dessa propriedade unicamente para o fim único de garantia e quando este fim se esgota com a extinção do crédito, fica obrigado a retrocessão do direito ao alienante. ${ }^{142}$

Como bem observa Melhim Chalhub ${ }^{143}$, a venda com escopo de garantia não é feita com o propósito de transmitir a propriedade de forma definitiva para o fiduciário, não se confundindo com a dação em pagamento.

\subsubsection{Propriedade Fiduciária}

A propriedade fiduciária está regulada na parte do Direito das Coisas - artigos 1.361 até 1.368-A - do Código Civil de 2002. O artigo 1.361 do Código Civil define como "fiduciária a propriedade resolúvel de coisa móvel infungível que o devedor, com escopo de garantia, transfere ao credor". O Código Civil trata, portanto, da propriedade fiduciária de coisa móvel infungível que pode ser utilizada tanto por pessoas físicas como jurídicas, permanecendo as demais espécies de propriedade ou titularidade fiduciária submetidas à disciplina específica das respectivas leis especiais, aplicando-se as disposições do Código Civil somente naquilo que não for incompatível com a lei especial.

A propriedade fiduciária de bem móvel constitui-se mediante o registro do contrato que lhe serve de título no Registro de Títulos e Documentos do domicílio do devedor, ou, em se tratando de veículos, na repartição competente para o licenciamento, fazendo-se a anotação no certificado de registro. Com a constituição da propriedade fiduciária, dá-se o desdobramento da posse, tornando-se o devedor possuidor direto da coisa.

\footnotetext{
${ }^{142}$ Francesco Ferrara, A Simulação dos Negócios Jurídicos, trad. A Bossa, 1939, pp. 80 e 81.

${ }^{143}$ Negócio Fiduciário, $4^{\mathrm{a}}$ ed., p. 50.
} 
Como bem salientam Paulo Restiffe Neto e Paulo Sérgio Restiffe ${ }^{144}$, a paralela adoção pelo Código Civil da propriedade fiduciária de caráter paritário geral não afetou nem revogou tacitamente a normatividade própria vigente da garantia fiduciária do âmbito do mercado financeiro e de capitais estabelecida em legislação especial, até porque nos termos do art. $2^{\circ}$ da LICC, a lei nova que estabeleça disposições gerais ou especiais a par das já existentes não revoga nem modifica a lei anterior. Com a entrada em vigor dos artigos 1.361 a 1.368-A do atual Código Civil, ficaram instituídos dois sistemas fiduciários paralelos, autônomos, mas harmônicos de garantia dominial mobiliária: o antigo mercadológico-financeiro especial e o novo paritário civil geral, cada qual regido em princípio pelas respectivas normatividades, como, aliás, deixou claro o superveniente artigo 1.368-A do Código Civil ${ }^{145}$, introduzido pelo art. 58 da Lei $\mathrm{n}^{\circ} 10.931$, de 02.08.2004.

\subsubsection{Alienação Fiduciária de Bens Móveis}

A alienação fiduciária de bens móveis foi originalmente regulada no artigo 66 da Lei de Mercado de Capitais, que estipulava que nas obrigações garantidas por alienação fiduciária de bem móvel, o credor teria o domínio da coisa alienada, até a liquidação da dívida garantida. Posteriormente, a redação do artigo 66 da Lei de Mercado de Capitais foi alterada pelo Decreto-lei $\mathrm{n}^{\circ}$ 911, de 01.10.1969, que procurou corrigir certas falhas de direito material contempladas na antiga redação do artigo 66, bem como disciplinar certas questões processuais visando à maior celeridade na execução da garantia. Desta forma, o caput do artigo 66 passou a descrever a alienação fiduciária em garantia como aquela que transfere ao credor o domínio resolúvel e a posse indireta da coisa móvel alienada, independentemente da tradição efetiva do bem, tornando-se o alienante ou devedor em possuidor direto e depositário com todas as responsabilidades e encargos que lhe incumbem de acordo com a lei civil e penal.

\footnotetext{
${ }^{144}$ Alienação Fiduciária e o Fim da Prisão Civil, p. 16.

${ }^{145} \mathrm{O}$ artigo 1.368-A do Código Civil assim dispõe: "as demais espécies de propriedade fiduciária ou de titularidade fiduciária submetem-se à disciplina específica das respectivas leis especiais, somente se aplicando as disposições deste Código naquilo que não for incompatível com a legislação especial."
} 
A alienação fiduciária em garantia somente se prova por escrito, e seu instrumento, público ou particular, qualquer que seja o seu valor, deve ser arquivado no Registro de Títulos e Documentos, sob pena de não valer contra terceiros, e deveria conter: o total da dívida ou sua estimativa; o prazo ou a época do pagamento; a taxa de juros, as comissões cuja cobrança fosse permitida e, eventualmente, a cláusula penal e a estipulação de correção monetária, com indicação dos índices aplicáveis; e a descrição da coisa objeto da alienação e os elementos indispensáveis à sua identificação.

O parágrafo $3^{\circ}$ do referido artigo 66 determinava que se a coisa alienada em garantia não se identificasse por números, marcas e sinais indicados no instrumento de alienação fiduciária, caberia ao proprietário fiduciário o ônus da prova, contra terceiros, da identidade dos bens do seu domínio que se encontram em poder do devedor.

O parágrafo $2^{\circ}$ do referido artigo 66 dispunha que se, na data do instrumento de alienação fiduciária, o devedor ainda não fosse proprietário da coisa objeto do contrato, o domínio fiduciário desta se transferiria ao credor no momento da aquisição da propriedade pelo devedor, independentemente de qualquer formalidade posterior.

O parágrafo $4^{\circ}$ do referido artigo 66 dispunha que no caso de inadimplemento da obrigação garantida, o proprietário podia vender a coisa a terceiros e aplicar o preço da venda no pagamento do seu crédito e das despesas decorrentes da cobrança, entregando ao devedor o saldo porventura apurado, se houvesse. Se o preço da venda não bastasse para pagar o crédito do proprietário fiduciário e despesas, o devedor continuaria pessoalmente obrigado a pagar o saldo devedor apurado.

Por fim, o parágrafo $6^{\circ}$ do referido artigo 66 estipulava que seria nula a cláusula que autorizasse o proprietário fiduciário a ficar com a coisa alienada em garantia, se a dívida não fosse paga no seu vencimento. 
Antes do advento da Lei $\mathrm{n}^{\circ}$ 10.931, de 02.08.2007 havia discussão na doutrina e jurisprudência sobre a admissibilidade ou não de alienação fiduciária de coisas fungíveis. Álvaro Villaça Azevedo ${ }^{146}$ entendia que o elemento objetivo da alienação fiduciária deveria ser móvel, descrito no contrato, com os elementos indispensáveis à sua identificação. Para ele, o objeto deveria ser infungível, mesmo com a alusão feita no parágrafo $3^{\circ}$ do invocado artigo 66, dado que, ante a impossibilidade da coisa identificar-se por número, marcas e sinais indicados no instrumento da alienação fiduciária, ao proprietário fiduciário caberá o ônus da prova, junto a terceiros, da identidade do mesmo objeto fiduciado.

José Carlos Moreira Alves ${ }^{147}$, embora entendesse que, a rigor, não deveriam ser admitidas coisas fungíveis na alienação fiduciária, pois em caso de não pagamento, o devedor deveria entregar ao credor não a coisa que lhe alienara, mas outra equivalente àquela, ele alerta que a Lei de Mercado de Capitais no que não havia sido modificada pelo Decreto-lei no 911 admitia, "de certa forma e ilogicamente”, que as coisas fungíveis pudessem ser objeto de alienação fiduciária.

Com a entrada em vigor da Lei $\mathrm{n}^{\mathrm{o}}$ 10.931, de 02.08.2004, foram derrogados os artigos 66 e 66-A da Lei de Mercado de Capitais e nela introduzido o art. 66-B, regulando o contrato de alienação fiduciária no âmbito do mercado financeiro e de capitais e estendendo a abrangência da alienação fiduciária para garantia de créditos fiscais e previdenciários. O parágrafo $3^{\circ}$ do já mencionado artigo 66-B admitiu expressamente a alienação fiduciária de coisa fungível, encerrando, portanto, a discussão sobre a possibilidade ou não de alienação fiduciária de coisa fungível. O artigo 66-B da Lei de Mercado de Capitais possui a seguinte redação:

Art. 66-B. O contrato de alienação fiduciária celebrado no âmbito do mercado financeiro e de capitais, bem como em garantia de créditos fiscais $e$ previdenciários, deverá conter, além dos requisitos definidos na Lei $n^{\circ}$ 10.406, de 10 de janeiro de 2002 - Código Civil, a taxa de juros, a cláusula penal, o índice de atualização monetária, se houver, e as demais comissões e encargos.

\footnotetext{
146 Alienação Fiduciária em Garantia de Bem Móvel e Imóvel. In: Revista da Faculdade de Direito da Fundação Armando Álvares Penteado, ano 1, nº 1 - 2002, p. 65

147 Da Alienação Fiduciária em Garantia, pp. 123 e 124.
} 
$\S 1^{\underline{o}}$ Se a coisa objeto de propriedade fiduciária não se identifica por números, marcas e sinais no contrato de alienação fiduciária, cabe ao proprietário fiduciário o ônus da prova, contra terceiros, da identificação dos bens do seu domínio que se encontram em poder do devedor.

$\S 2^{\circ}$ O devedor que alienar, ou der em garantia a terceiros, coisa que já alienara fiduciariamente em garantia, ficará sujeito à pena prevista no art. $171, \S 2^{\underline{o}}, I$, do Código Penal.

$\S 3^{o} E$ É admitida a alienação fiduciária de coisa fungível e a cessão fiduciária de direitos sobre coisas móveis, bem como de títulos de crédito, hipóteses em que, salvo disposição em contrário, a posse direta e indireta do bem objeto da propriedade fiduciária ou do título representativo do direito ou do crédito é atribuída ao credor, que, em caso de inadimplemento ou mora da obrigação garantida, poderá vender a terceiros o bem objeto da propriedade fiduciária independente de leilão, hasta pública ou qualquer outra medida judicial ou extrajudicial, devendo aplicar o preço da venda no pagamento do seu crédito e das despesas decorrentes da realização da garantia, entregando ao devedor o saldo, se houver, acompanhado do demonstrativo da operação realizada.

$\S 4^{o}$ No tocante à cessão fiduciária de direitos sobre coisas móveis ou sobre títulos de crédito aplica-se, também, o disposto nos arts. 18 a 20 da Lei $n^{o}$ 9.514, de 20 de novembro de 1997.

$\S 5^{0}$ Aplicam-se à alienação fiduciária e à cessão fiduciária de que trata esta Lei os arts. 1.421, 1.425, 1.426, 1.435 e 1.436 da Lei $n^{\circ}$ 10.406, de 10 de janeiro de 2002.

$\S 6^{o}$ Não se aplica à alienação fiduciária e à cessão fiduciária de que trata esta Lei o disposto no art. 644 da Lei $n^{-}$10.406, de 10 de janeiro de 2002."

O contrato de alienação fiduciária é definido por Melhim Chalhub como sendo o negócio jurídico pelo qual o devedor, também chamado fiduciante, com escopo de garantia, contrata a transferência ao credor, ou fiduciário, da propriedade resolúvel de determinada coisa móvel ou da titularidade resolúvel de direito sobre coisa móvel ou de título de crédito. Em regra, com a constituição da propriedade fiduciária ou da titularidade fiduciária desdobra-se a posse, ficando o devedor com a posse direta e o credor com a posse indireta sobre o bem objeto da garantia. Entretanto, nas hipóteses em que o objeto da garantia seja coisa fungível ou direito sobre bem móvel e, ainda, quando se tratar de título de crédito, a regra é a atribuição da posse direta e indireta ao credor, salvo disposição contratual em contrário. ${ }^{148}$

\footnotetext{
${ }^{148}$ Negócio Fiduciário, $4^{\mathrm{a}}$ ed., p. 158.
} 
José Carlos Moreira Alves define a alienação fiduciária em garantia como o negócio jurídico bilateral, que visa transferir a propriedade de coisa móvel com fins de garantia (propriedade fiduciária). E acrescenta que, embora nem a Lei de Mercado de Capitais nem o Decreto-lei $n^{\circ} 911$ usem a expressão contrato para caracterizar a alienação fiduciária em garantia, não há dúvida de que se está diante de negócio jurídico bilateral, análogo aos que visam à constituição dos direitos reais de garantia e que são denominados contratos pelo Código Civil. O referido autor adverte que alienação fiduciária em garantia, ao contrário do que sucede com os contratos de penhor, anticrese e hipoteca, não visa à constituição de direitos reais limitados, mas à transferência do direito de propriedade limitado pelo escopo de garantia. Apesar disso, apresenta-se ela, em nosso sistema jurídico, também como contrato de direito das coisas. ${ }^{149}$

Por sua vez, Orlando Gomes define a alienação fiduciária em garantia como o negócio jurídico consistente na transmissão da propriedade, limitada por uma relação obrigacional que distorce o fim natural do contrato translativo. A alienação é meio para alcançar o fim de garantia. Desnatura-se, porque se destina a um fim menor do que decorre de sua causa e constitui uma propriedade temporária. Na formação desse negócio jurídico, conjugam-se dois vínculos: o de transmissão de propriedade e o de seu retorno ao patrimônio do transmitente. ${ }^{150}$ Orlando Gomes acrescenta, ainda, que a alienação fiduciária em garantia é modalidade de propriedade resolúvel. ${ }^{151}$

A natureza jurídica da alienação fiduciária em garantia é a de contrato de direito real, muito embora ela não vise à constituição de direitos reais limitados sobre coisa alheia (penhor, hipoteca, anticrese), mas à transferência do direito de propriedade do devedor fiduciante ao credor fiduciário. Nesta transferência, porém, ocorre uma desfiguração da propriedade plena havida pelo devedor em função do escopo de garantia com que se transmite o domínio, limitando-o. ${ }^{152}$

\footnotetext{
${ }^{149}$ Da Alienação Fiduciária em Garantia, pp. 51 a 53.

${ }^{150}$ Alienação fiduciária em garantia, $4^{\mathrm{a}}$ ed., p. 34.

${ }^{151}$ Ibid., p. 47.

${ }^{152}$ Guilherme Guimarães Feliciano, Tratado de Alienação Fiduciária Em Garantia: Das Bases Romanas à Lei . 9.514/97, p. 105.
} 


\subsubsection{Alienação Fiduciária de Bens Imóveis}

A alienação fiduciária de bens imóveis está regulada no artigo 22 e seguintes da LSFI. O referido instituto foi de fundamental importância para incentivar o financiamento de imóveis e, consequientemente, ajudar no crescimento e fortalecimento do Sistema Financeiro Imobiliário - SFI.

Alienação fiduciária de bem imóvel é o negócio jurídico pelo qual o devedor, ou fiduciante, transfere a propriedade resolúvel desse imóvel, ao credor, ou fiduciário, com escopo de garantia. Os elementos subjetivos da alienação fiduciária são, em princípio, os mesmos da alienação de bem móvel, diferindo, tão somente, em que, na alienação de bem imóvel, pode esta ser contratada por qualquer pessoa, física ou jurídica, não sendo privativa das entidades que operam no SFI. No tocante ao elemento objetivo, o objeto da aquisição deve ser imóvel, concluído ou em construção. Admite-se, contudo, que a contratação tenha por objeto coisa futura e, neste caso, todas as garantias devem ser dadas aos adquirentes de boa-fé. ${ }^{153}$

\subsubsection{Alienação Fiduciária de Ações, Partes Beneficiárias e Bônus de Subscrição}

A alienação fiduciária de ações, partes beneficiárias e bônus de subscrição está regulamentada nos artigos 40, 100 e 113 da Lei das Sociedades por Ações.

$\mathrm{O}$ acionista transfere a titularidade de suas ações para um terceiro, estipulando a finalidade da transferência e as condições do exercício dessa titularidade. Extinta a finalidade da transferência, deverá o terceiro restituir ao acionista as ações que foram objeto da transferência. $\mathrm{O}$ direito de voto do acionista-fiduciante fica preservado, mas deve observar as restrições impostas no contrato de alienação fiduciária de ações. 153 Álvaro Villaça Azevedo. Alienação Fiduciária em Garantia de Bem Móvel e Imóvel. In: Revista da
Faculdade de Direito da Fundação Armando Álvares Penteado, ano 1, no $1-2002, \mathrm{p} .79$. 


\subsubsection{Cessão Fiduciária de Crédito}

A cessão fiduciária de direitos creditórios no âmbito do Sistema Financeiro Imobiliário encontra-se regulada nos artigos 17 a 20 da LSFI. ${ }^{154}$

A cessão fiduciária de direitos sobre coisas móveis e de títulos de crédito no âmbito do mercado financeiro e de capitais está regulada nos parágrafos $3^{\circ}$ e $4^{\circ}$ do artigo 66-B da Lei de Mercado de Capitais, com a redação dada pela Lei $n^{\circ} 10.931 / 2004$. A este tipo de cessão fiduciária também se aplicam os artigos 18 a 20 da LSFI e os artigos 1.421, 1.425, $1.426,1.435$ e 1.436 do CC.

O cedente-fiduciante cede títulos de crédito ou direito de créditos de que é titular ao cessionário-fiduciário, para a garantia de uma obrigação assumida pelo cedente-fiduciante em face do cessionário-fiduciário. Por meio da cessão, o cessionário é investido da condição de credor, com todos os poderes inerentes a este, inclusive o de valer-se de todas as ações e execuções a que o credor está legitimado, mas, recebendo o crédito, não pode ficar com o produto, apenas retendo-o até que o devedor-cedente pague sua dívida. ${ }^{155}$

Se o cedente cumprir a obrigação assumida em face do cessionário-fiduciário, nasce a obrigação de o cessionário retransmitir o crédito cedido. Se o cedente não cumprir a obrigação principal, o cessionário poderá utilizar os créditos cedidos para liquidar a dívida, desde que tais créditos já tenham vencidos, com a conseqüente extinção da obrigação garantida. Se os créditos cedidos ainda não tiverem vencidos, poderá o cessionário alienar os referidos créditos, ficando com o produto da alienação e se o referido produto for superior à dívida garantida, o cessionário terá que restituir ao cedente a diferença.

A cessão fiduciária de crédito e/ou títulos de crédito no âmbito do mercado financeiro e de capitais será melhor detalhada no Capítulo III deste trabalho.

\footnotetext{
${ }^{154}$ Esta lei dispõe sobre o Sistema de Financiamento Imobiliário, instituindo a alienação fiduciária de coisa imóvel.

${ }^{155}$ Melhim Namem Chalhub, Negócio Fiduciário, $4^{\mathrm{a}}$ ed., p. 51.
} 


\section{CAPÍTULO III - CESSÃO FIDUCIÁRIA}

No presente capítulo, trataremos do instituto da cessão fiduciária de crédito e de títulos de crédito. Na primeira parte deste capítulo, abordaremos a disciplina da cessão de créditos de uma forma geral, desde sua origem até a forma como ela atualmente encontrase regulada no Código Civil Brasileiro. Depois, passaremos a tratar especificamente do instituto da cessão fiduciária de crédito e/ou títulos de crédito no âmbito do mercado financeiro e de capitais, procurando delinear suas principais características e procurando, também, confrontá-la com outros institutos próximos tais como o penhor de direitos creditórios e a alienação fiduciária em garantia. Por fim, serão abordados os efeitos patrimoniais da cessão fiduciária de créditos e/ou títulos de crédito, para identificarmos se a cessão fiduciária de créditos e/ou títulos de crédito constituiria ou não um patrimônio especial do credor-fiduciário.

\subsection{Origem da Cessão}

A transmissão das obrigações pode apresentar-se sob a forma ativa (cessão de crédito) ou passiva (cessão de débito), entre pessoas vivas (inter vivos) ou em virtude de falecimento (mortis causa), podendo ser a título universal, quando abrange todos os bens ou uma fração da totalidade dos bens do cedente ou a título singular, quando só se refere a um crédito específico. O direito primitivo romano considerava o vínculo obrigacional tão pessoal e ligado às pessoas do credor e do devedor que não admitia a transmissão de obrigações a não ser mortis causa. ${ }^{156}$

Assim era o princípio romano, remontado a uma época em que o caráter pessoal da obrigação era muito forte, e a diferença entre o direito real e o obrigacional, em vez de desaparecer, tornou-se mais profunda. ${ }^{157}$ Importante ressaltar que no direito romano primitivo a própria pessoa do devedor poderia sofrer execução pessoal nos casos de descumprimento de obrigação.

\footnotetext{
${ }^{156}$ Arnold Wald, Curso de Direito Civil Brasileiro - Obrigações e Contratos, $2^{\mathrm{a}}$ ed., p. 143.

${ }^{157}$ Pietro Bonfante, Istituzioni di diritto romano, p. 413.
} 
Os romanos, sem negar os princípios tradicionais e sem reconhecer o instituto da cessão, sugeriram a aplicação de outros institutos para a consecução do mesmo resultado. Um deles foi a novação, pela qual não se transfere o crédito, mas se constitui uma nova obrigação com o mesmo objeto da anterior, que se extingue. ${ }^{158}$

Alexandre Correia e Gaetano Sciascia anotam o inconveniente da novação, pois exigia-se a cooperação do devedor, que deveria executar a ordem de pagar a outro credor e exigir o consentimento do cessionário, além disso pela novação a antiga obrigação se extinguia, desaparecendo as garantias que lhe podiam ser acrescentadas. ${ }^{159}$

Para evitar esses inconvenientes, os jurisconsultos recorreram a um meio de natureza processual: a procuratio in rem suam, por meio da qual o cedente constituía o cessionário como seu procurador que ingressava com uma ação contra o cedido (devedor), obtendo do pretor uma fórmula, cuja intentio indicava o nome do cedente e cuja condemnatio assinalava o nome dele próprio, cessionário (fórmula em transposição de sujeitos), a quem o devedor réu era condenado a pagar. Entretanto, o expediente ainda era imperfeito, por se lhe aplicarem as regras do mandato, que se extingue pela revogação ou morte duma das partes; pois, no caso em que, antes da litis contestatio, se verificasse uma das duas circunstâncias - a revogação ou a morte, o cessionário mandatário ficava privado da ação para realizar seu crédito. Acresce que o devedor cedido antes da condenação podia pagar ao cedente, exonerando-se da dívida com prejuízo do cessionário, que ignorava o pagamento. Alexandre Correia e Gaetano Sciascia anotam, também, que nas obras dos jurisconsultos imperiais era possível identificar-se casos em que se concediam actiones utilis ao cessionário. O imperador Gordiano estabeleceu que quando o cedente fizesse a cessão deveria notificar o devedor de que doravante o credor era o cessionário. As actiones utilis foram multiplicando-se e mais tarde, no direito justinianeu, pela fusão dos sistemas, a cessão de créditos foi admitida como instituto autônomo e independente do mandato. ${ }^{160}$

\footnotetext{
${ }^{158}$ Biondo Biondi, Istituzioni di Diritto Romano, p. 261.

${ }^{159}$ Alexandre Correia e Gaetano Sciascia, Manual de Direito Romano, p. 180.

${ }^{160}$ Alexandre Correia e Gaetano Sciascia, Manual de Direito Romano, p. 180. Ver sobre este assunto: Pontes de Miranda, Tratado de Direito Privado - Parte Especial - Tomo XXIII, $3^{\mathrm{a}}$ ed., p. 248 e Pietro Bonfante, Istituzioni di diritto romano, p. 413.
} 
Luís Manuel Teles de Menezes Leitão esclarece que um dos argumentos usados pelos glosadores para a impossibilidade de transmissão do crédito era o fato de os créditos não serem suscetíveis de posse e, portanto, não admitirem a traditio, negócio necessário para a transmissão de bens. Mais ainda, os glosadores só admitiam a aquisição de posse em relação às coisas corpóreas, seja em nome próprio ou alheio, mas não para bens incorpóreos, onde se incluiriam os créditos. ${ }^{161}$

Posteriormente, a doutrina jusnaturalista fundada por Huig de Groot trouxe uma concepção diferente da cessão de créditos, reconhecendo que o direito de crédito, à semelhança da propriedade sobre coisas corpóreas, é um elemento do patrimônio do credor, que poderia ser assim transmissível como qualquer outro componente patrimonial. $^{162}$

Em suma, enquanto o antigo direito romano considerava a obrigação apenas como um vínculo pessoal entre credor e devedor, não admitindo terceiros nessa relação contratual, assim como restringia o conceito de propriedade às coisas corpóreas, a doutrina jusnaturalista traz uma importante contribuição ao enxergar o valor econômico do crédito e considerá-lo como um bem que poderia integrar o patrimônio de seu titular, podendo, assim, ser livremente transmitido a terceiros. A doutrina jusnaturalista aceitou, pois, a propriedade sobre bens incorpóreos, notadamente créditos e direitos, aproximando a cessão da traditio das coisas corpóreas.

\subsection{Disposições Gerais sobre a Cessão}

\subsubsection{Conceito, Natureza Jurídica, Tipos e Sujeitos}

Como bem observa Orlando Gomes, a cessão de crédito é um negócio translativo, pelo qual o credor originário transfere seu direito, praticando assim ato de disposição. ${ }^{163}$

\footnotetext{
${ }^{161}$ Cessão de Créditos, p. 47.

${ }^{162}$ Luís Manuel Teles de Menezes Leitão, Cessão de Créditos, p. 129.

${ }^{163}$ Introdução ao Direito Civil, p. 330. No mesmo sentido, Pontes de Mirando, Tratado de Direito PrivadoParte Especial - Tomo XXIII, $3^{\text {a }}$ ed., p. 267.
} 
Atualmente, a cessão está regulada nos artigos 286 a 298 do Código Civil no Título que trata da Transmissão das Obrigações.

Para Serpa Lopes a cessão de crédito possui natureza contratual não em sentido estrito, por representar um ato de disposição por força do qual o crédito sai do patrimônio do cedente para se incorporar no do cessionário. Por ser contrato, a cessão estaria subordinada a todos os princípios reguladores do contrato, precipuamente na parte relativa à sua formação, aos vícios de vontade, consentimento e capacidade. ${ }^{164}$

No mesmo sentido, Silvio de Salvo Venosa entende que a natureza contratual do negócio é patente. É um contrato simplesmente consensual, mas por vezes a necessidade obrigará o escrito particular ou a forma pública. ${ }^{165}$ Da mesma forma, Orlando Gomes entende que o contrato de cessão é simplesmente consensual, não havendo necessidade de tradição do documento para sua perfeição, bastando o acordo de vontades entre cedente e cessionário. Em alguns casos, porém, a natureza do título exige a entrega, assimilando-se aos contratos reais. ${ }^{166}$ Por outro lado, Pontes de Miranda defende que a declaração de vontade da cessão não supõe contrato ${ }^{167}$.

Alguns doutrinadores classificam a cessão como negócio jurídico abstrato, pois independe do negócio jurídico subjacente ou sobrejacente (cessão de crédito para servir de garantia a negócio jurídico de outrem, ou do próprio cedente). Para esses doutrinadores no fenômeno da cessão seria possível identificar dois atos distintos, quais sejam: a transferência do crédito (cessão propriamente dita) e o contrato que lhe dá causa. ${ }^{168}$

No direito brasileiro, Pontes de Miranda, influenciado pelo direito alemão, entendeu que a cessão de crédito é negócio jurídico bilateral, porém a cessão de crédito independe dele, ou da sua existência. A manifestação da vontade é elemento de acordo de

\footnotetext{
${ }^{164}$ Curso de Direito Civil, v. II, p. 412.

${ }^{165}$ Direito Civil: teoria geral das obrigações e teoria geral dos contratos, v. II, $8^{\text {a }}$ ed. p. 144.

${ }^{166}$ Obrigações, $11^{\mathrm{a}}$ ed., p. 205.

${ }^{167}$ Tratado de Direito Privado - Parte Especial - Tomo XXIII, $3^{\text {a }}$ ed., p. 270.

${ }^{168}$ Nesse sentido, Pontes de Miranda, Tratado de Direito Privado - Parte Especial - Tomo XXIII, $3^{\mathrm{a}}$ ed., p. 269; Ennecerus, Tratado de Derecho Civil - Tomo II - Derecho das Obligaciones, $2^{\mathrm{a}}$ ed., trad. por Blás Pérez González e José Alguer, p. 382; Andreas Von Tuhr, Tratado de las Obligaciones, Tomo II, trad. por W. Rocesp, p. 289, Luís Manuel Teles de Menezes Leitão, Cessão de Créditos, p. 446.
} 
transmissão, e esse acordo, semelhante ao acordo de transmissão da propriedade imobiliária ou mobiliária, opera a transmissão sem precisar de qualquer outro elemento (e.g., na transferência da propriedade imobiliária, o registro; na transferência da propriedade mobiliária, a tradição, ou outro ato, inclusive o registro). ${ }^{169}$

Para outros autores, a cessão é negócio jurídico causal dada a íntima relação que se observa entre o ato que transmite o crédito e o negócio jurídico subjacente que lhe deu causa. ${ }^{170}$ Esta posição nos parece a mais adequada em face do ordenamento jurídico brasileiro.

Interessante é a posição adotada por Pestana de Vasconcelos que não considera a cessão como um negócio jurídico em si, com uma causa própria. Para ele, o fato jurídico que desencadeia a transmissão do crédito é o próprio contrato onde a transferência desse direito está incluída, e não em qualquer contrato de cessão posterior. A cessão do crédito resulta diretamente do seu contrato-base, que poderá ser uma compra e venda, uma doação, um mútuo, etc. Assim, o referido autor não concebe a cessão como um negócio abstrato, pois a cessão seria um mero efeito de um negócio causal e nem sequer seria um negócio em si. ${ }^{171}$

Na cessão há uma alteração subjetiva da obrigação, indiretamente realizada, porque se completa por via de uma transladação de força obrigatória, de um sujeito ativo para outro sujeito ativo, mantendo-se em vigor o vinculum iuris originário. Difere-se da novação e do pagamento com sub-rogação, em que não opera a extinção da obrigação, mas, ao revés, permanece esta viva e eficaz. Apenas a soma dos poderes e das faculdades inerentes à razão creditória, sem modificação no conteúdo ou natureza da obligatio,

\footnotetext{
${ }^{169}$ Pontes de Miranda, Tratado de Direito Privado - Parte Especial - Tomo XXIII, $3^{\text {a }}$ ed., p. 268.

${ }^{170}$ Nesse sentido, Orlando Gomes, Obrigações, $11^{\mathrm{a}}$ ed., p. 206; Clóvis do Couto e Silva, Cessão de Crédito. In: Revista dos Tribunais, ano 77, Dezembro de 1988, v. 638, p. 10-14, p. 11; Maria Izolina Schaurich Alster, A cessão de crédito: natureza jurídica. In: Revista dos Tribunais, ano 81, Agosto de 1992, v. 682 p. 39-49, p. 47; Rodrigo Xavier Leonardo, A cessão de créditos: reflexões sobre a causalidade na transmissão de bens no direito brasileiro, p. 359. In: JABUR, Gilberto Haddad; PEREIRA JR., Antonio Jorge (Coords.). Direito dos Contratos II. São Paulo: Quartier Latin, 2008; Vincenzo Panuccio, La cessione volontaria dei crediti: nella teoria del trasferimento, p. 65.

${ }^{171}$ A cessão de créditos em garantia e a insolvência: em particular da posição do cessionário na insolvência do cedente, pp. 375 e 377 , nota 736.
} 
desloca-se da pessoa do cedente para a daquele que lhe ocupa o lugar na relação obrigacional. ${ }^{172}$

Os sujeitos da cessão são o cedente, quem cede o crédito, e o cessionário, quem aceita o crédito. A cessão de crédito pode ser convencional, quando decorre de acordo de vontades entre o cedente e cessionário; legal, quando surge em virtude de lei; e judicial, quando se apresenta como conseqüência necessária de uma sentença judicial, que pode ter sido homologatória de uma partilha ou adjudicatória ao autor de um crédito existentes em favor do réu. ${ }^{173}$

Para efetivar-se a cessão, o cedente deverá ter capacidade para a prática dos atos da vida civil e deverá ter o poder de disposição do objeto a ser cedido. Exceto quando a cessão é legal ou judicial, que independe da assinatura de instrumento público ou particular, a cessão convencional poderá ser feita por instrumento público ou instrumento particular revestido das solenidades previstas no parágrafo $1^{\circ}$ do artigo 654 do $\mathrm{CC}$, isto é, deverá conter a indicação do lugar onde foi celebrado, a qualificação das partes, a data e o objetivo da cessão.

Quanto à necessidade de registro do instrumento de cessão no Registro de Títulos e Documentos, Caio Mario da Silva Pereira ${ }^{174}$ afirma que o registro da cessão feita por instrumento particular é requisito essencial à sua eficácia, pois que é ineficaz em relação a terceiros, a não ser que revista de forma pública. Importante mencionar que o artigo 129, item $9^{\circ}$ da Lei ${ }^{\circ}$ 6.015, de 31.12.1973 (“Lei de Registros Públicos”) dispõe que estão sujeitos a registro, no Registro de Títulos e Documentos, para surtir efeitos em relação a terceiros os instrumentos de cessão de direitos e de créditos, de sub-rogação e de dação em pagamento.

\footnotetext{
${ }^{172}$ Caio Mario da Silva Pereira, Instituições de Direito Civil, v. 2 - Teoria Geral das Obrigações, 20ª ed., p. 361. No mesmo sentido, Pontes de Miranda, Tratado de Direito Privado - Parte Especial - Tomo XXIII, p. 835.

${ }_{174}^{173}$ Arnold Wald, Curso de Direito Civil Brasileiro - Obrigações e Contratos, $2^{\mathrm{a}}$ ed., p. 144.

${ }^{174}$ Instituições de Direito Civil, v. 2 - Teoria Geral das Obrigações, $20^{a}$ ed., p. 371.
} 


\subsubsection{Objeto da Cessão}

Como regra geral, todos os créditos ou direitos obrigacionais são transmissíveis, com todos os seus acessórios e garantias, salvo se, quanto a estes, houver disposição em contrário. Orlando Gomes ensina que na expressão "acessórios do crédito" estão abrangidos todos os direitos vinculados ao crédito, não só os acessórios propriamente ditos, mas, também, os direitos de preferência. Compreendem-se entre os direitos acessórios: os de garantia real ou fidejussória do crédito; os juros; os direitos potestativos inerentes ao crédito, tais como: o direito de escolha nas obrigações alternativas e o direito de constituir o devedor em mora, dentre outros. ${ }^{175}$

Dentre os direitos acessórios que são transferidos com o crédito, também é possível incluir-se o direito de voto na Assembléia Geral de Credores (“AGC”) do devedor nas hipóteses de recuperação judicial e/ou falência. O credor original não poderá votar na referida AGC, pois não é mais titular do crédito. Erasmo Valladão defende que pode-se ceder o crédito (e com ele o voto), mas não é possível separar uma coisa da outra. ${ }^{176}$

Menezes Leitão ensina que a cessão tem como efeito principal a transmissão do crédito do cedente para o cessionário, que se torna o novo titular do crédito e conseqüentemente aquele que tem a faculdade de exigir a prestação do devedor, permanecendo o cedente como parte contratual no âmbito da relação contratual que tenha originado esse crédito, uma vez que essa qualidade somente seria transmissível ao cessionário em havendo uma cessão da posição contratual. ${ }^{177}$

Todavia, observa o referido autor que a cessão de créditos não implica em uma cisão absoluta entre o direito de crédito visto isoladamente e a respectiva posição contratual, uma vez que não apenas as garantias e os acessórios do crédito são transmitidos ao cessionário, como também se tem admitido o exercício de certos direitos potestativos por parte deste, por exemplo, o devedor poderá opor ao cessionário as exceções que possuir contra o cedente, incluindo a exceção de não cumprimento do contrato, o que

\footnotetext{
${ }^{175}$ Obrigações, $11^{\mathrm{a}}$ ed., p. 208.

176 In: Francisco Satiro de Souza Jr.; e Antônio Sergio A. de Moraes (Coords.); Comentários à Lei de Recuperaçã̃ de Empresas e Falência, p. 210.

${ }^{177}$ Cessão de Créditos, p. 314.
} 
demonstra que, não obstante a transmissão, a cessão de créditos não vai provocar nenhuma autonomização do crédito em relação à posição contratual, reconhecendo-se, assim, que com o crédito ocorre simultaneamente a transmissão para o cessionário de pelo menos um parte da posição contratual, ainda que outra parte se mantenha na esfera do cedente. ${ }^{178}$

As restrições quanto à cessão podem decorrer da lei, da vontade das partes, ou ainda, da natureza da obrigação, como, por exemplo, as obrigações intuitu personae. A cessão de um crédito que não poderia ter sido cedido será inválida entre as partes e não será oponível a terceiros. A cessão pode ser total ou parcial, assim como pode ter por objeto créditos e/ou direitos já existentes na esfera do cedente, bem como créditos futuros.

\subsubsection{Cessão de Créditos Futuros}

Quanto à admissibilidade de ceder créditos futuros, há entendimento divergente da doutrina. Pontes de Miranda admite a cessão de créditos futuros, ressaltando, apenas, que se exige a perfeita caracterização do que se cede, isto é, que, ao nascer o crédito, se saiba, ao certo, qual será o crédito cedido. ${ }^{179}$

Ennecerus também admite a cessão de créditos futuros ou de um crédito que só futuramente seja adquirido pelo cedente, mas adverte que a transmissão nesses casos somente opera-se no momento em que o crédito nascer em favor do cedente. Observa este autor que os requisitos de conclusão do negócio, por exemplo, a capacidade dos contraentes, tem que existir no momento da conclusão, mas os demais requisitos, se o efeito difere-se a um momento ulterior, somente ocorrerão no momento em que deva produzir-se o efeito. Não se pode transmitir para entrega uma coisa futura, pois a entrega é um requisito da conclusão do negócio, mas é possível ceder-se um crédito futuro, pois o contrato de cessão se conclui exclusivamente mediante a declaração de vontade das partes, e a transmissão do crédito é somente um efeito do negócio. ${ }^{180}$

\footnotetext{
${ }^{178}$ Ibid., p. 314.

${ }^{179}$ Tratado de Direito Privado - Parte Especial - Tomo XXIII, $3^{\text {a }}$ ed., p. 275.

${ }^{180}$ Tratado de Derecho Civil - Tomo II - Derecho das Obligaciones, $2^{\mathrm{a}}$ ed., trad. por Blás Pérez González e José Alguer, p. 385 e nota 14.
} 
Von Tuhr admite a possibilidade de cessão prévia de todos os créditos futuros do cedente que nasçam de suas relações comerciais com um devedor e, também, todos os créditos que o cedente adquirir em sua empresa comercial, mas adverte que no caso concreto poderia se discutir se o pacto é contrário aos bons costumes. Von Tuhr também adverte que na cessão de créditos futuros (assim como na cessão dos já existentes), o objeto da cessão deve ser de tal modo determinado para que não haja dúvida acerca de qual crédito futuro foi cedido. ${ }^{181}$

Carlos Alberto da Mota Pinto também admite a cessão de créditos futuros, ainda não surgidos, englobando nessa categoria os que vêm a surgir pro rata temporis (p.ex., os créditos de rendas futuras no arrendamento), quer aqueles cuja fonte ou tipo legal (fattispecie) constitutivo ainda deve ser completado (p.ex., o crédito às contraprestações em contrato de fornecimento sucessivo onde o montante da prestação ainda há de ser determinado; o crédito aos dividendos futuros no contrato de sociedade), quer aqueles cujo fundamento só surge com o decurso do tempo (créditos ligados a certo tipo de seguro, de renda vitalícia, etc.). ${ }^{182}$ Ao comentar sobre a admissibilidade da cessão prévia de todos os créditos futuros procedentes de um negócio, principalmente para servir de garantia de empréstimos bancários, o referido autor ressalta que na Alemanha este tema já vem sendo discutido e a jurisprudência e a doutrina têm, na sua maioria, admitido ambas as figuras, salvo se falta a determinação ou outros requisitos gerais. ${ }^{183}$

Menezes Leitão também admite a cessão de créditos futuros desde que esteja preenchido o requisito de determinabilidade, podendo esta resultar quer de negócio jurídico já celebrado (ex. rendas futuras relativas a um arrendamento vigente), quer de negócio ainda não celebrado (ex. preço das mercadorias que o cedente irá vender). Não havendo obstáculos ao tipo de evento futuro que determine a constituição do crédito a ser cedido, admitindo-se quer a cessão de créditos resultantes de um futuro contrato, quer a cessão de créditos a ser instituído por uma lei futura. ${ }^{184}$

\footnotetext{
${ }^{181}$ Tratado de las Obligaciones, Tomo II, traduzido do alemão por W. Roces, p. 303.

${ }_{182}$ Cessão de Contrato: contendo parte tratando a matéria conforme o direito brasileiro, p. 187.

${ }^{183}$ Ibid., p. 188 e nota de rodapé 7.

${ }^{184}$ Cessão de Créditos, p. 419.
} 
Por outro lado, Orlando Gomes não admite a cessão de créditos futuros sob a alegação de que a cessão de crédito é negócio dispositivo, devendo seu objeto ser determinado, não se permitindo a transferência de créditos que não possam ser individualizados. Assim, não vale a cessão de todos os créditos futuros procedentes de negócios. Seria contrato imoral. ${ }^{185}$

Em que pese a opinião de Orlando Gomes, adotamos o entendimento de que é possível a cessão de créditos futuros desde que eles sejam determinados ou determináveis.

Questão controversa é saber se o crédito futuro que foi previamente cedido nasce na pessoa do cedente ou diretamente na pessoa do cessionário. Nesse sentido, a doutrina alemã formulou duas teorias que posteriormente influenciaram o direito italiano e o português, quais sejam: a teoria da transmissão (Durchgangstheorie), na qual se defende que o crédito futuro cedido, no momento em que vem a nascer, constitui-se na pessoa do cedente e, só depois, passa para o cessionário; e a teoria da imediação (Unmittelbarkeitstheorie), que admite que o crédito futuro cedido já nasça na pessoa do cessionário, sendo essa teoria a mais aceita na Alemanha. ${ }^{186}$

Von Tuhr, como um dos defensores da teoria da imediação, sustenta que a cessão prévia de crédito futuro produz efeitos na pessoa do cessionário. O cedente, vinculado por seu ato prematuro de disposição, não pode impedir que este resultado se produza. A partir do momento em que o crédito futuro é cedido, ele não poderá ser atingido pelos credores do cedente. Os efeitos do ato antecipado de disposição se produzem ainda que o cedente venha a falecer ou perca a capacidade de trabalhar depois de efetuada a cessão. ${ }^{187}$

Os defensores da teoria da imediação sustentam que não há nenhuma necessidade racional de construção que implique se deva sustentar que o crédito surja primeiro na esfera do cedente, parecendo ser mais lógico que se deva sustentar que a constituição do crédito ocorre diretamente na esfera do cessionário.

\footnotetext{
${ }^{185}$ Obrigações, $11^{\mathrm{a}}$ ed., p. 207.

${ }^{186}$ Carlos Alberto da Mota Pinto, Cessão de Contrato: contendo parte tratando a matéria conforme o direito brasileiro, p. 188-190; Luís Manuel Teles de Menezes Leitão, Cessão de Créditos, p. 421.

${ }^{187}$ Tratado de las obligaciones, Tomo II, traduzido do alemão para o espanhol por W. Roces, p. 302.
} 
Por outro lado, os defensores da teoria da transmissão sustentam que no caso de celebração de uma cessão de créditos futuros, não se verifica a constituição direta do crédito na esfera jurídica do cessionário, verificando-se antes essa constituição na esfera jurídica do cedente, onde o crédito permanece por um segundo lógico, sendo, porém, imediatamente a seguir transferido para o cessionário, em virtude do negócio de cessão anteriormente celebrado. Neste entendimento, a cessão de créditos futuros apenas se distinguiria da cessão de créditos já existentes em virtude de a transmissão do crédito ser diferida para o momento da sua futura constituição, sendo em tudo o mais aplicável o mesmo regime. ${ }^{188}$

Carlos Alberto da Mota Pinto observa que os pressupostos de aquisição do crédito futuro pelo cessionário devem verificar-se na pessoa do cedente e que a teoria da imediação só poderia ser aceita se os requisitos de aquisição do crédito devessem concorrer na pessoa do cessionário. Ele ressalta, ainda, que o cessionário só virá a adquirir o direito se o cedente, sem a cessão, o tivesse adquirido e o seu regime será o mesmo a que estaria sujeito na titularidade do cedente. ${ }^{189}$ Menezes Leitão também contraria frontalmente a teoria da imediação sob o argumento de que ela cinde os pressupostos da cessão e suas consequiências jurídicas, já que o negócio da cessão visa transmitir um crédito e não criá-lo diretamente na esfera alheia. ${ }^{190}$ São defensores desta teoria, dentre outros, EnnecerusLehman $^{191}$, Carlos Alberto da Mota Pinto ${ }^{192}$ e Luiz Manuel Teles de Menezes Leitão ${ }^{193}$.

Menezes Leitão cita, ainda, uma posição intermediária entre as duas teorias, seguida por João de Matos Antunes Varela e Luís Miguel D. P. Pestana de Vasconcelos, que sustentam a necessidade de distinguir créditos futuros em relação aos quais já exista um fundamento de vigência (como os créditos que se poderão constituir em virtude da verificação de uma condição ou do vencimento de um termo, e ainda os créditos cuja futura constituição possa ser determinada em virtude de um negócio celebrado) dos

\footnotetext{
${ }^{188}$ Luís Manuel Teles de Menezes Leitão, Cessão de Crédito, p. 422.

${ }^{189}$ Cessão de Contrato: contendo parte tratando a matéria conforme o direito brasileiro, p. 191.

${ }^{190}$ Cessão de Créditos, p. 424.

${ }^{191}$ Tratado de Derecho Civil - Tomo II - Derecho das Obligaciones, 2 a ed., trad. por Blás Pérez González e José Alguer, p. 385 e nota 14.

${ }_{192}$ Cessão de Contrato: contendo parte tratando a matéria conforme o direito brasileiro, p. 193.

${ }^{193}$ Cessão de Créditos, p. 424.
} 
créditos em que falte totalmente esse fundamento de vigência (como os que poderão resultar de negócios a celebrar futuramente). ${ }^{194}$

Para Antunes Varela sempre que entre o cedente e o devedor cedido já estivesse constituída ao tempo da cessão a relação contratual duradoura donde esses créditos hão de surgir, o direito nascerá, em princípio, diretamente na esfera do cessionário, visto este ter adquirido desde logo, a partir da celebração da cessão, a expectativa jurídica, que é o gérmen do futuro crédito; se a transferência tiver por objeto créditos cujo contrato donde hão de emergir ainda não foi sequer celebrado, os direitos nascem primeiro na esfera do cedente, só depois transferindo-se para o adquirente. ${ }^{195}$

No mesmo sentido, Pestana de Vasconcelos entende que não se pode concluir sem mais, sem outro ponto de apoio, que a solução consagrada na lei para a transferência de créditos futuros implica necessariamente que estes nasçam primeiro na esfera do cedente antes de se transferirem para o cessionário, quando não se tenha verificado uma sucessão singular numa relação contratual existente donde eles devem vir a emergir. ${ }^{196}$

A teoria da transmissão nos parece a mais adequada ao ordenamento jurídico brasileiro, primeiro porque o artigo 295 do CC determina que na cessão a título oneroso, o cedente é responsável perante o cessionário pela existência do crédito ao tempo em que o cedeu. Admitindo-se como juridicamente possível a cessão prévia de todos os créditos futuros advindos de uma determinada relação jurídica, neste momento o cessionário terá apenas uma expectativa de vir a ser titular do crédito futuro. Como bem esclarece Carlos Alberto da Mota Pinto, o cessionário só virá a adquirir o direito se o cedente, sem a cessão, o tivesse adquirido. ${ }^{197}$ Significa dizer, portanto, que o cedente só terá como responsabilizar-se pela existência do crédito futuro no momento em que este vier a nascer e que será, portanto, nos termos da teoria da transmissão, o momento em que tal crédito será de fato transmitido ao cessionário. Em suma, na cessão de crédito futuros os créditos nascem primeiramente na esfera do cedente e só depois são transferidos para o cessionário.

\footnotetext{
194 Ibid., p. 423.

195 João de Matos Antunes Varela, Das Obrigações em Geral, v. II, p. 316.

${ }^{196}$ A cessão de créditos em garantia e a insolvência: em particular da posição do cessionário na insolvência do cedente, p. 469.

${ }^{197}$ Cessão de Contrato: contendo parte tratando a matéria conforme o direito brasileiro, p. 191.
} 


\subsubsection{Validade e Eficácia da Cessão}

A cessão é válida e eficaz entre cedente e cessionário a partir do momento da celebração do contrato de cessão, pois a cessão é um contrato consensual que se perfaz pelo acordo de vontades entre cedente e cessionário. Todavia, para que a cessão seja eficaz em relação ao devedor, exige-se que ele seja notificado da cessão nos termos do art. 290 do Código Civil, mas por notificado se tem o devedor que, em escrito público ou particular, se declarou ciente da cessão feita. Isto porque, o devedor deverá saber a quem pagar o crédito, já que houve substituição do credor originário. Assim, antes de ser notificado da cessão, poderá o devedor pagar diretamente ao credor originário, como se a cessão não tivesse ocorrido. O artigo 292 do Código Civil claramente desobriga o devedor que, antes de ter conhecimento da cessão, paga ao credor primitivo, ou que, no caso de mais de uma cessão notificada, paga ao cessionário que lhe apresenta, com o título de cessão, o da obrigação cedida.

Quando o crédito constar de escritura pública, prevalecerá a prioridade da notificação. O problema maior na identificação do credor ocorre quando há várias cessões do mesmo crédito. Em se tratando do título do crédito cedido, será considerado credor/cessionário aquele que apresentar o título ao devedor. No entanto, não estando o crédito incorporado em um título, a doutrina entende que será credor aquele que em primeiro lugar notificou o devedor ${ }^{198}$. Como bem adverte Serpa Lopes, notificado o devedor, o contrato de cessão adquire plenitude dos seus efeitos, deles resultando principalmente a vinculação imediata do devedor ao credor cessionário. ${ }^{199}$ Todavia, subsiste para o devedor cedido o direito de opor ao cessionário as exceções que lhe competirem, bem como as que, no momento em que veio a ter conhecimento da cessão, tinha contra o cedente, nos termos do artigo 294 do Código Civil.

\footnotetext{
${ }^{198}$ Pontes de Miranda distingue as cessões constantes de títulos que têm que ser restituídos pelo credor por ocasião da extinção da dívida dos que não têm que ser restituídos. No primeiro caso, notificado da cessão o devedor, ou entregue por ele declaração escrita, a eficácia da cessão, em relação a ele, está estabelecida. Se o título tinha de ser restituído, a notificação ou a declaração produz os seus efeitos, porém a risco do devedor se não exigiu que o cessionário lhe apresentasse o título. Se o documento ou título não é da classe dos que têm de ser restituídos por ocasião da extinção da dívida, a cessão a que se referiu a primeira notificação é que é a eficaz, ou aquela a que concerne a primeira declaração escrita. (Tratado de Direito Privado - Parte Especial - Tomo XXIII, p. 832)

${ }^{199}$ Curso de direito civil, v. II, $5^{\text {a }}$ ed., p. 417.
} 


\subsubsection{Efeitos da Cessão de Crédito}

Na cessão a título oneroso, o cedente é responsável pela existência do crédito ao tempo em que o cedeu, nos termos do artigo 295 do CC. Desta forma, subsiste a responsabilidade do cedente em três hipóteses: a) se transfere crédito inexistente; b) se contra o crédito cedido existe exceção, que o inutiliza, como a de dolo ou compensação; c) o crédito tem existência positiva, mas não em favor do cedente, que assim aliena bem alheio. ${ }^{200} \mathrm{Na}$ cessão a título gratuito, o cedente não é responsável pela existência do crédito ao tempo em que o cedeu, exceto se tiver agido de má-fé.

Como bem salienta Pestana de Vasconcelos, a letra da lei refere-se somente à exigibilidade do crédito ao tempo da cessão, mas tal só poderá ser assim se estivermos perante obrigações puras ou já vencidas. Na eventualidade de se tratar de um crédito a prazo, a garantia da exigibilidade terá que se reportar necessariamente ao tempo do vencimento. $^{201}$

Em regra, o cedente não responde pela solvência do devedor, exceto se convencionado de outra forma entre as partes. No silêncio das partes, entende-se que o cedente não responde pela solvência do devedor. Como bem salienta Pontes de Miranda, assumida a responsabilidade pela solvência do devedor, entende-se, em caso de dúvida, que só se garante a solvabilidade no momento da cessão, salvo se ainda não se venceu a dívida. Assim, se houve a assunção de responsabilidade e o crédito já se venceu, a responsabilidade da solvência somente é no momento da cessão do crédito. Se o crédito ainda não se venceu, ou não pode ser exigido, a responsabilidade é até o vencimento. ${ }^{202}$

Na cessão pro soluto o cedente garante a existência do crédito, mas não se obriga pelo inadimplemento do devedor. Na cessão pro solvendo o cessionário responderá pela solvência do devedor, devendo pagar ao cessionário os valores inadimplidos pelo devedor,

\footnotetext{
${ }^{200}$ Washington de Barros Monteiro, Curso de Direito Civil, v. 4, p. 349.

${ }^{201}$ A cessão de créditos em garantia e a insolvência: em particular da posição do cessionário na insolvência do cedente, p. 529.

${ }^{202}$ Tratado de Direito Privado - Parte Especial, Tomo XXIII, $3^{\mathrm{a}}$ ed., p. 319.
} 
pelo menos até o limite do que recebeu do devedor, com os respectivos juros, devendo, ainda, ressarcir o cessionário pelos custos que ele incorreu para a cobrança do devedor.

Feitas as considerações acerca das regras gerais aplicáveis à cessão, passaremos a analisar o instituto da cessão fiduciária e sua aplicação como garantia das operações realizadas no âmbito do mercado financeiro e de capitais.

\subsection{Conceito de Cessão Fiduciária}

A cessão é um instrumento largamente utilizado com o escopo de garantia de um negócio subjacente ou ainda com a finalidade de cobrança. Com bem salienta Orlando Gomes, a cessão realizada para alcançar a primeira finalidade denomina-se cessão fiduciária e a outra denomina-se cessão para cobrança. A cessão fiduciária é negócio fiduciário, pois o crédito é verdadeiramente transferido, mas com outra finalidade, porque o cedente quer, para si, sua realização. Pela confiança que deposita no cessionário, efetua a cessão, mas no intuito de que, uma vez cobrado, lhe seja, a ele cedente, transferido o seu objeto. Na cessão fiduciária, compromete-se o cessionário a entregar ao cedente o que recebeu do devedor. Mas a cessão é negócio definitivo, de modo que o cessionário passa a ser verdadeiro e exclusivo titular do direito de crédito. ${ }^{203}$

Pontes de Miranda define a cessão fiduciária como uma espécie de transferência fiduciária. Esclarece o referido autor que conforme o direito que se transfere fiduciariamente, ou há cessão de direito ou transferência da propriedade, ou de direito real limitado (e.g. do direito enfitêutico). A cessão fiduciária é a transmissão fiduciária que dá ensejo à titularidade fiduciária do direito pessoal, enquanto a transferência fiduciária da propriedade dá ensejo à titularidade fiduciária do direito real. A transferência fiduciária, por cessão ou por transferência da propriedade, só o é porque fica sujeita a fim, que não é o da transmissão mesma e implica a reversão ipso jure, ou o dever do fiduciário de retrotransmitir. ${ }^{204}$ Uma das espécies de cessão fiduciária é para segurança, na qual o cessionário pode cobrar o crédito quando já exigível, no seu interesse (pois que foi garantido com a cessão) e no do credor cedente, que se libera e tem direito a receber o

\footnotetext{
203 Obrigações, $11^{\mathrm{a}}$ ed., p. 211.

${ }^{204}$ Tratado de Direito Privado - Parte Especial - Tomo XXIII, $3^{\text {a }}$ ed., p. 283.
} 
excesso sobre o seu débito. A respeito da cessão fiduciária para segurança, só há retrotransferência ipso iure (reversão automática, como se dá com a propriedade imobiliária resolúvel), se a cessão fiduciária foi feita sob a condição resolutiva de ser solvida a dívida pelo cedente. ${ }^{205}$

$\mathrm{Na}$ doutrina italiana destaca-se o trabalho de Giuseppe Messina como um dos principais estudiosos dos negócios fiduciários. Ensina o referido autor que a cessão será fiduciária quando a investidura do direito de crédito no cessionário for feita com a confiança de que ele, conquanto tenha se tornado um cessionário real, tenha a obrigação de restituir o quanto for exigido. ${ }^{206}$ Continua Messina observando que a cessão fiduciária com fins de garantia dá ao credor uma garantia maior do que a do penhor de crédito, pois com a transferência do crédito se assegura, de um lado, ao cessionário-fiduciário uma posição mais independente em comparação com a posição do devedor-cedente; e, de outro, se protege a futura disposição que o devedor-pignoratício poderia fazer de seu crédito. ${ }^{207}$

Cariota-Ferrara ensina que a cessão fiduciária consiste em um negócio fiduciário que se pode dizer real, que é a transferência do direito de crédito (cessão), e de um negócio obrigatório que corresponde ao escopo do contrato, que pode ser de cobrança ou de garantia. O escopo da fidúcia não tem influência sobre a cessão, que produz os mesmos efeitos da cessão ordinária: o fiduciário, enquanto cessionário, adquire a titularidade plena e absoluta do crédito, tornando-se credor perante todos, incluindo o cedente (fiduciante). $\mathrm{O}$ devedor cedente pode experimentar contra ele somente aquelas exceções que lhe competem contra qualquer cessionário, não tendo a faculdade de referir-se ao negócio interno (obrigatório) entre fiduciante e fiduciário. ${ }^{208}$

\footnotetext{
205 Ibid., p. 285.

${ }^{206}$ Scritti Giuridici, v. 1 - Negozi Fiduciari, p. 11 (tradução livre de: "Allora la cessione sarebbe fiduciaria quando l'investitura del diritto di credito nel cessionario fosse fatta correndo la fede di quest'ultimo, quando cioè lo si rendesse cessionario reale, ma com l'obbligo di restituire quanto esigerà.")

207 Scritti Giuridici, v. 1 - Negozi Fiduciari, p. 12 (tradução livre de: "Ritornando ora alle applicazioni fiduciarie della cessione, dobbiamo ricordare da ultimo quella fatta per scopo di sicurtà. Vi si ricorre per concedere al creditore una garanzia più intensa di quella fornita dal pegno da crediti. Poichè col trasferimento del credito si assicura da un lato al cessionario-fiduciario una posizione più libera ed indipendente in confronto al debitore ceduto, dall'altro lo si salvaguarda da ulteriori disposizioni che il debitore pignoratizio potrebbe fare del credito.")

${ }^{208}$ I negozi fiduciari: trasferimento cessione e girata a scopo di mandato e di garanzia. Processo fiduciario, p. 170 (tradução livre de: "Consta di un negozio che possiamo dire reale, che è il negozio di trasferimento del diritto di credito (cessione), e di un rapporto obbligatorio che corrisponde allo scopo del contratto, che può essere scopo d'incasso o di garanzia.") e p. 171 (tradução livre de: "Lo scopo di fiducia non ha alcuna influenza sulla cessione, la quale produce gli stessi effetti della cessione ordinaria: il fiduciario, in quanto
} 
Para Ennecerus, a verdadeira cessão fiduciária que, com um fim que não exige esta transmissão, transfere o crédito, está sujeita às regras gerais sobre as transmissões fiduciárias, ou seja, que faz do cessionário um credor no lugar do cedente, outorgando assim, de maneira exclusiva, as faculdades de disposição. ${ }^{209}$

Von Tuhr defende que a cessão poderá ser empregada para a realização de fins que poderiam ser alcançados por outros recursos jurídicos. O referido autor denomina cessão fiduciária a cessão feita com fins de garantia, porque o cessionário adquire um poder jurídico que extravasa a finalidade do ato, assumindo a obrigação de não empregar o crédito além do objeto pactuado com o cedente, reintegrando a este uma vez alcançada a finalidade que se persegue. A cessão fiduciária tem todos os requisitos e produz todos os efeitos de uma cessão normal. O cessionário é credor e tem, como tal, a livre disposição sobre o crédito, assim como o direito de exercitá-lo em seu próprio nome contra o devedor. O pacto fiduciário que serve de base à cessão somente confere ao cedente um direito de natureza pessoal que o autoriza a exigir a retrocessão do crédito, ou a correspondente indenização, se o cessionário deixar de cumprir as obrigações assumidas. O crédito cedido fiduciariamente pertence, ainda que o cedente não se reintegre nele por uma nova cessão, ao patrimônio do cessionário, sujeitando-se às ações de seus credores. Em caso de falência do cessionário, o cedente não poderá pedir que o crédito cedido se separe da massa, e terá tão somente um crédito contra ele. ${ }^{210}$

Navarro Martorell define a cessão fiduciária como o contrato de cessão de direitos de crédito para fins de cobrança ou de garantia. Mediante referido contrato, o credor recebe em plena propriedade o direito cedido, convertendo-se assim em verdadeiro proprietário dele (como fiduciário que é) não somente frente a terceiros, como também em sua relação interna com o cedente, restando clara a desproporção entre o meio empregado e o fim proposto. $^{211}$

cessionario, acquista la titolarità piena ed assoluta del credito, diventa creditore di fronte a tutti, compreso il cedente (fiduciante). Il debitore ceduto può sperimentare contro di lui soltanto quelle eccezioni che gli competono contro qualunque cessionario, non avendo facoltà di risalire all rapporto interno (obbligatorio), tra fiduciante e fiduciario.)

${ }^{209}$ Tratado de Derecho Civil - Tomo II - Derecho das Obligaciones, 2a ed., trad. por Blás Pérez González e José Alguer, p. 393 e 394.

${ }_{210}$ Tratado de las obligaciones, Tomo II, traduzido do alemão para o espanhol por W. Roces, p. 294 e 295.

${ }^{211}$ La Propriedad Fiduciaria, p. 313. 
Menezes Leitão diz que a cessão de créditos em garantia tem caráter fiduciário. $\mathrm{O}$ cariz fiduciário do negócio resulta do fato de que, como titular do crédito, o cedente, poderá, em princípio, dispor dele em absoluto, alienando-o ou procedendo à sua cobrança. No entanto, como é convencionada a afetação do crédito em garantia, o cessionário fica vinculado para o com o cedente a não proceder à obtenção do valor do crédito (através da cobrança ou alienação), uma vez que o deverá retroceder em caso de satisfação do crédito que se visou garantir. Apesar desse dever, o cessionário não deixa de possuir essas faculdades, pelo que, caso ele venha a efetuar a cobrança do crédito, o devedor não se poderá opor, invocando os direitos do cedente. A sanção para o incumprimento pelo cessionário será apenas a sua responsabilidade contratual em face do cedente. ${ }^{212}$

\subsubsection{Natureza Jurídica da Cessão Fiduciária: direito real ou obrigacional?}

Por ser a cessão um ato de transmissão de obrigações que muito se assemelha à transmissão da propriedade imobiliária, gerou-se controvérsia na doutrina sobre a natureza jurídica da cessão fiduciária, se ela deveria ser inserida no direito real ou no direito das obrigações.

Melhim Chalhub defende que a cessão fiduciária tem caráter de direito real. ${ }^{213}$ No mesmo sentido, Otto Von Gierke defende que a transferência de crédito não podia ser posta no direito das obrigações, pois não há obrigados e sim transmitentes; nenhuma obrigação nasce; transmite-se o direito, pretensão, ação ou exceção. ${ }^{214}$

Cariota-Ferrara ensina que a cessão fiduciária consiste em um negócio fiduciário que se pode dizer real, que é a transferência do direito de crédito (cessão), e de um negócio obrigatório que corresponde ao escopo do contrato, que pode ser de cobrança ou de garantia. $^{215}$

\footnotetext{
${ }^{212}$ Cessão de Créditos, p. 445.

${ }^{213}$ Negócio Fiduciário, p. 356.

${ }^{214}$ Deutsches Privatrecht, III, p. 186 e ss. apud Pontes de Miranda, Tratado de Direito Privado, Tomo XXIII, p. 269.

${ }^{215}$ I negozi fiduciari: trasferimento cessione e girata a scopo di mandato e di garanzia. Processo fiduciario, pp. 170 e 171.
} 
Alguns doutrinadores adotam um conceito mais amplo e elástico do direito real. Nesse sentido, Manoel Ignácio Carvalho de Mendonça, ao discorrer sobre as teorias acerca do direito real, observa que a opinião clássica e dominante é a de que o direito real recai diretamente sobre a coisa, enquanto o de crédito é um vínculo entre o credor e o devedor. $\mathrm{Na}$ opinião do referido autor, esta teoria exagera o papel da coisa no direito real e o do devedor no direito de crédito e, ignorando o caráter social do direito, rompe a harmonia entre eles. $^{216}$

Continua o referido autor declarando que o direito real é um poder que a sociedade reconhece no titular sobre uma coisa do mundo externo; o direito de crédito é o mesmo poder que a sociedade reconhece no indivíduo para limitar momentaneamente a liberdade de outrem e exigir-lhe um fato, uma prestação. Os elementos das duas séries, portanto, são: a) o titular do direito, ou o poder reconhecido; b) o poder que o titular tem sobre a coisa (direito real) ou sobre a pessoa (direito obrigacional), por cujo motivo existe o direito. Mas nunca a pessoa do devedor no direito de crédito, nem a coisa no direito real constitui objeto do direito. $^{217}$

J.W. Hedemann fala da necessidade de retificar a concepção do direito de crédito como simples relação interna entre credor e devedor sem qualquer transcendência em relação aos demais, ou seja: não é necessário ampliar a dogmática do direito real, senão construir adequadamente o conceito de direito subjetivo, e mui especialmente, o de direito subjetivo patrimonial, nele inoculando, com caráter de generalidade, a idéia de dominação sobre um valor econômico, idéia que à primeira vista só se observa no campo dos direitos reais. $^{218}$

Na mesma linha, Serpa Lopes diz que a tendência dos direitos reais se manifesta no sentido de serem ampliados a outras categorias jurídicas, onde se sinta a existência de um poder sobre um valor econômico. Por conseguinte, a orientação do direito moderno não se norteia por uma concepção restritiva dos direitos reais, circunscrita aos elementos tangíveis e corpóreos, senão para abranger os elementos incorpóreos. ${ }^{219}$

\footnotetext{
${ }^{216}$ Introducção Geral ao Direito das Cousas (dos direitos reais), p. 93.

${ }^{217}$ Ibid., p. 96.

${ }^{218}$ Derechos Reales, v. II, versão espanhola traduzida por Jose Luiz Diez Pastor e Manuel Gonzalez Enriquez p. 12

${ }^{219}$ Introdução ao Direito Civil,. v. VI, p. 56.
} 
Por outro lado, há os que defendem que a cessão não poderia ser inserida no direito real. Ennecerus argumenta que conduz a erros conceber ou qualificar a cessão como contrato real. ${ }^{220}$

No mesmo sentido, Von Tuhr observa que a cessão, por recair sobre um crédito, é contrato que se insere no direito das obrigações. Mas não constitui um contrato em sentido estrito, i.e., uma convenção criadora de obrigações mas um ato de disposição por meio do qual o crédito sai do patrimônio do cedente e entra no patrimônio do cessionário. A cessão teria, portanto, mais semelhança com a transmissão da propriedade do que com o contrato como fonte de obrigações, mas não poderia qualificar-se, como, às vezes, se faz, com o contrato real, pois esta denominação deve reservar-se para aqueles contratos cuja função é a de modificar direitos reais. Não obstante ser um ato de disposição, aplicam-se à cessão os preceitos destinados primordialmente a regulamentar os contratos como fonte de obrigações e, principalmente as normas sobre contratação, vícios de vontade e de representação. Ademais, a cessão pode, como todo contrato, realizar-se sob uma condição (suspensiva ou resolutiva) ou com sujeição a um termo inicial ou final. Ao cumprir-se esta condição se opera, ipso jure, o trânsito do crédito ao cessionário e, ao realizar-se a condição resolutiva, se opera também, ipso jure, a reversão do crédito ao cedente. ${ }^{221}$

Da mesma forma, Vincenzo Panuccio adverte que não soa bem falar-se em eficácia real em sentido estrito e rigoroso em um negócio translativo de crédito que é de direito pessoal. O referido autor aponta como uma característica distinta entre cessão e venda a de que a cessão produz efeitos imediatos. ${ }^{222}$

Entre nós, Pontes de Miranda ensina que a cessão de direitos em segurança, se o direito é pessoal, passa-se no direito das obrigações no que se refere à transferência. ${ }^{223}$ Este autor, ao conceituar a cessão fiduciária, diz expressamente que ela é a transmissão fiduciária que dá ensejo à titularidade fiduciária do direito pessoal, enquanto a transferência fiduciária da propriedade dá ensejo à titularidade fiduciária do direito

\footnotetext{
${ }^{220}$ Tratado de Derecho Civil - Tomo II - Derecho das Obligaciones, $2^{\mathrm{a}}$ ed., traduzido do alemão para o espanhol por Blás Pérez González e José Alguer, p. 382, nota 2 a.

${ }^{221}$ Tratado de las Obligaciones, Tomo II, traduzido do alemão por W. Roces, p. 286-287.

${ }_{222}^{22}$ Cessione volontaria dei crediti nella teoria del trasferimento, p. 98.

${ }^{223}$ Tratado de direito privado, Tomo XXI, p. 356.
} 
real.(grifo nosso $)^{224}$ No mesmo sentido, Maria Izolina Schaurich Alster defende que a cessão de crédito está inserida no plano do direito das obrigações. ${ }^{225}$

A natureza jurídica da cessão fiduciária ainda é um assunto pouquíssimo explorado pela doutrina e merece ser interpretada levando-se em consideração que a cessão fiduciária, como espécie de negócio fiduciário, é um negócio jurídico único composto por duas relações jurídicas, isto é, um negócio dispositivo de transferência de créditos ao credor-fiduciário como forma de garantia de outro negócio jurídico de natureza obrigacional, usualmente o mútuo.

Ao nosso ver, a cessão de um crédito decorrente de um negócio jurídico de caráter obrigacional se passa no direito das obrigações. Todavia, no caso específico da cessão fiduciária de créditos e/ou títulos de crédito algumas considerações adicionais merecem ser feitas.

A cessão fiduciária de créditos ou de títulos de crédito, como espécie do gênero alienação fiduciária, possui grande semelhança com a traditio das coisas corpóreas. Da mesma forma que a alienação fiduciária, a cessão fiduciária confere ao credor-fiduciário a plena e efetiva titularidade do crédito, ainda que temporária, pois somente o será enquanto perdurar a dívida.

A alienação fiduciária de bens móveis e imóveis depende do registro do contrato no Registro competente para dar efeito constitutivo da propriedade fiduciária. Da mesma forma, adotamos o entendimento de que a cessão fiduciária de créditos e/ou títulos de crédito deverá ser registrada no Registro de Títulos e Documentos para dar efeito constitutivo da titularidade fiduciária em favor do credor-fiduciário. ${ }^{226}$

Por todo o exposto, embora admitamos que a cessão fiduciária de créditos permanece inserida no direito das obrigações, acreditamos que ela também produz efeitos de direito real, especialmente se considerarmos a plena e efetiva titularidade do crédito

${ }^{224}$ Tratado de direito privado - Parte Especial - Tomo XXIII, $3^{\mathrm{a}}$ ed., p. 283.

${ }^{225}$ A Cessão de Crédito: Natureza Jurídica. In: Revista dos Tribunais, ano 81, Agosto de 1992, v. 682, p. 48.

${ }^{226}$ As semelhanças e diferenças entre alienação fiduciária e cessão fiduciária serão melhor tratadas no item 3.3.3 deste trabalho. A necessidade de registro do contrato de cessão fiduciária será melhor tratada no item 3.7 deste trabalho. 
pelo credor-fiduciário e a necessidade do registro do contrato de cessão fiduciária de créditos no Registro de Títulos e Documentos, como efeito constitutivo da titularidade fiduciária e também como efeito erga omnes perante terceiros.

\subsubsection{Distinção entre Cessão Fiduciária de Crédito em Garantia e Penhor de Direitos e} Títulos de Créditos

Embora exista grande semelhança entre a cessão fiduciária de créditos em garantia e o penhor de direitos e títulos de crédito, no sentido de que ambos funcionam como garantia de obrigações assumidas pelas partes, a cessão fiduciária de créditos distingue-se do penhor pelas seguintes razões:

A cessão fiduciária de crédito é eficaz entre as partes apenas com o acordo de vontades entre cedente e cessionário e é eficaz em relação ao devedor a partir de sua notificação. Por outro lado, a eficácia do penhor está condicionada à notificação do devedor, nos termos do artigo 1.453 do CC.

Ainda que possa haver várias cessões do mesmo crédito, na cessão há a substituição do credor e, portanto, não podem coexistir vários credores em relação ao mesmo crédito. Em se tratando de penhor é perfeitamente possível que o mesmo crédito seja objeto de vários penhores, estabelecendo-se uma ordem de preferência entre os credores pignoratícios.

O penhor é um direito real de garantia, cujo efeito dele decorrente é a afetação de um determinado bem do devedor para satisfação prioritária do credor. O penhor, portanto, cria em benefício do credor garantido um direito de preferência ou prelação no recebimento. O penhor também tem por atributo o direito de seqüela, ou seja, o penhor segue a coisa. Assim, transmitido o bem empenhado continua ele afetado ao cumprimento da obrigação garantida. Desta forma, o credor tem direito a perseguir o bem empenhado com quem quer que ele se encontre. 
Diferentemente do penhor em que há a constituição de garantia real sobre coisa alheia, na cessão fiduciária de créditos em garantia há a efetiva transferência do crédito para o cessionário-fiduciário, que deterá a titularidade plena do referido crédito, devendo retransmiti-lo ao devedor tão logo ele cumpra a obrigação contida no negócio subjacente. ${ }^{227}$ Como o crédito cedido passa a fazer parte do patrimônio do cessionário, tal crédito estará sujeito à ação dos credores do cessionário, assim como integrará a massa falida do cessionário se este vier a falir. Em se tratando de penhor, o credor pignoratício adquire um mero direito de garantia que tem por objeto um direito que se mantém na esfera patrimonial do devedor. $\mathrm{O}$ credor pignoratício tem, apenas, um direito de preferência em relação ao devedor.

Pode-se dizer que a diferença entre cessão fiduciária de crédito e penhor de direitos e títulos de crédito é mais marcante nas hipóteses de recuperação judicial e/ou falência do devedor-cedente ou do devedor pignoratício, uma vez que os referidos institutos são tratados pela LRE de forma diferente. ${ }^{228}$

Nos termos do artigo 49 da LRE, os créditos empenhados estão sujeitos à recuperação judicial do devedor, devendo observar-se o disposto no parágrafo $5^{\circ}$ do referido artigo com relação à impossibilidade de o credor utilizar os créditos empenhados durante o prazo de suspensão das ações e execuções (stay-period), correspondente a 180 dias contados do deferimento do processamento da recuperação judicial. Tais créditos deverão ficar depositados em conta vinculada à recuperação, enquanto não renovada ou substituída a garantia liquidada ou vencida durante a recuperação judicial. Na hipótese de falência do devedor, o credor pignoratício é credor com garantia real.

No que tange ao credor-fiduciário, a doutrina diverge sobre o seu tratamento nas hipóteses de recuperação judicial e falência do devedor fiduciante. Parte da doutrina defende que tais créditos não estão sujeitos aos efeitos da recuperação judicial do devedor-

\footnotetext{
${ }^{227}$ Navarro Martorell (La Propriedad Fiduciaria, p. 316) também adota o entendimento de que a cessão de créditos em garantia não se confunde com o penhor, pois enquanto no penhor o crédito permanece em poder do devedor pignoratício, na cessão fiduciária em garantia o credor adquire plena e absoluta propriedade do crédito. O cedente está obrigado na cessão fiduciária em garantia a proporcionar ao cessionário tal direito de propriedade e a colocá-lo em posição de poder exercer seus direitos de um modo pleno e absoluto.

${ }_{228}$ Importante mencionar que muitas vezes, erroneamente, os juízes igualam a figura da cessão fiduciária de crédito ao penhor. Veja nesse sentido Agravo de Instrumento $\mathrm{n}^{\mathbf{0}}$ 2009.002.02081 do TJRJ, relator Des. Alexandre Freitas, decisão proferida em 25.03.2009.
} 
fiduciante, enquanto outra parte defende que tais créditos estão sujeitos aos efeitos da recuperação judicial do devedor-fiduciante. Sendo este o tema central da presente dissertação, abordaremos mais detalhadamente essa questão no Capítulo IV da presente dissertação.

\subsubsection{Distinção entre Cessão Fiduciária de Crédito e Alienação Fiduciária em Garantia}

A cessão fiduciária de títulos de crédito é considerada por alguns doutrinadores e por parte da jurisprudência como espécie do gênero alienação fiduciária. Nesse sentido, Sergio Campinho sustenta que quando a alienação fiduciária em garantia tiver por objeto direito de crédito passa a ser por lei denominada de cessão fiduciária. ${ }^{229}$

Domenico Barbero observa que é certo que a alienação onerosa de um direito, denominada cessão, possui as características da venda, mas sua função econômica não correspondente necessariamente ao esquema legal desse contrato, objetivado na troca de uma coisa por dinheiro para a transferência da propriedade. Todavia, desde que se considere o crédito no seu aspecto econômico de valor patrimonial, a semelhança aperta, não se podendo duvidar de que a cessão de crédito entre na categoria genérica, e, portanto, mais ampla, da alienação. ${ }^{230}$

Maria Helena Diniz conceitua "alienação" como o ato de alienar, ou seja, transferir gratuita ou onerosamente a outrem um direito ou a propriedade de uma coisa, que, então, passará a integrar o patrimônio alheio. ${ }^{231}$ No mesmo sentido, De Plácido e Silva conceitua "alienação" como o termo jurídico, de caráter genérico, pelo qual se designa todo e qualquer ato que tem o efeito de transferir o domínio de uma coisa para outra pessoa, seja por venda, por troca ou doação. Também indica o ato por que se cede ou transfere um direito pertencente ao cedente ou transferente. ${ }^{232}$

\footnotetext{
${ }^{229}$ Falência e Recuperação de Empresa, p. 391.

${ }^{230}$ Sistema Istituzionale del Diritto Privado Italiano, t. II, p. 203.

${ }^{231}$ Dicionário Jurídico, v. 1, p. 164.

${ }^{232}$ Vocabulário Jurídico, v. 1, p. 132.
} 
Existem algumas decisões judiciais cujo fundamento adotado é o de que a cessão fiduciária de créditos seria espécie do gênero "alienação fiduciária"

“RECUPERAÇÃO JUDICIAL - CESSÃO FIDUCIÁRIA DE TÍTULOS DE CRÉDITO - ESPÉCIE DE ALIENAÇÃO FIDUCIÁRIA EM GARANTIA - LEI N. ${ }^{\circ}$ 9.514/97, ART. 17, II, E ART. 66-B, $\S$ 4o, DA LEI N. ${ }^{\circ}$ 4.728/65 APLICABILIDADE DO § 30 DO ART. 49 DA LEI 11.101/2005 - RECURSO IMPROVIDO." (TJSP, Câmara Especial de Falências e Recuperações Judiciais, Agravo de Instrumento $\mathrm{n}^{\mathrm{o}}$ 649.263-4/7-00, julgado em 17.11.2009, relator Des. Elliot Akel)

"RECUPERAÇÃO JUDICIAL - CESSÃO FIDUCIÁRIA DE TÍTULOS DE CRÉDITO - ESPÉCIE DE ALIENAÇÃO FIDUCIÁRIA EM GARANTIA - LEI N 9.514/97, ART. 17, II, E ART. 66-B, $\S 4^{\circ}$, DA LEI N. ${ }^{\circ}$ 4.728/65 APLICABILIDADE DO \& $3^{\circ}$ DO ART. 49 DA LEI 11.101/2005 - HIPÓTESE, CONTUDO, EM QUE A GARANTIA CONTRATUAL INCIDE SOBRE 50\% DO SALDO DEVEDOR - RECURSO PARCIALMENTE PROVIDO.” (TJSP, Câmara Especial de Falências e Recuperações Judiciais, Agravo de Instrumento $n^{\circ}$ 649.2644/1-00, julgado em 17.11.2009, relator Des. Elliot Akel)

Nos parece admissível incluir a cessão fiduciária como espécie do gênero alienação fiduciária e acreditamos que esta foi a mesma intenção do legislador ao prever a cessão fiduciária no artigo 66-B da Lei de Mercado de Capitais, que já tratava da alienação fiduciária. Ainda que tais institutos tenham a relação de espécie e gênero, existem algumas diferenças entre eles que merecem ser comentadas.

Na alienação fiduciária há 3 (três) sujeitos: o comprador, o vendedor e o financiador. $\mathrm{O}$ comprador compra o bem do vendedor e o aliena fiduciariamente ao financiador, que passa a figurar como proprietário do referido bem. Quanto a cessão fiduciária, Paulo Restiffe Neto e Paulo Sergio Restiffe salientam que há uma transferência de direitos (crédito) ao próprio financiador, cuja titularidade adquire como cessionário. Os sujeitos do contrato de cessão fiduciária são, pois, a instituição financeira e o empresário contemplado com o financiamento. ${ }^{233}$

Também quanto ao objeto distinguem-se ambos os institutos. A alienação fiduciária pode ter por objeto bens móveis, imóveis e coisas fungíveis. Já a cessão fiduciária tem por objeto direitos sobre coisas móveis ou sobre títulos de crédito.

${ }^{233}$ Garantia Fiduciária, p. 42. 
Outra diferença é que as regras de satisfação do credor-fiduciário em caso de inadimplemento do devedor-fiduciante são diferentes na alienação fiduciária de bens imóveis e de bens móveis infungíveis, se comparadas com as regras da cessão de crédito.

$\mathrm{Na}$ alienação fiduciária de bens imóveis e de bens móveis infungíveis, o devedor detém a posse direta do bem alienado fiduciariamente e, em caso de inadimplemento, poderá o credor valer-se da ação de busca e apreensão do bem, nos termos do disposto no Decreto-lei no 911/1969. Importante notar, todavia, que na alienação fiduciária de bens móveis fungíveis o parágrafo $3^{\circ}$ do artigo 66-B da Lei de Mercado de Capitais permite que o credor detenha a posse direta e indireta do bem alienado fiduciariamente.

Assim, em caso de inadimplemento do devedor-fiduciante, o credor fiduciário poderá vender a terceiros o bem objeto da propriedade fiduciária independentemente de leilão, hasta pública ou qualquer outra medida judicial ou extrajudicial, devendo aplicar o preço da venda no pagamento de seu crédito e das despesas decorrentes da realização da garantia, entregando ao devedor o saldo, se houver, acompanhado do demonstrativo da operação realizada.

Por sua vez, na cessão fiduciária de crédito em garantia não há necessidade de ingresso de medida judicial para que o credor-fiduciário satisfaça o seu crédito. Isto porque, o credor-fiduciário detém a posse direta e indireta dos créditos que foram cedidos fiduciariamente e é o responsável por receber diretamente do devedor do cedente (devedorfiduciante) os valores relativos a tais créditos.

Assim, o inadimplemento do devedor-fiduciante no contrato principal firmado com o credor-fiduciário constituirá causa de vencimento antecipado da dívida, nos termos do artigo 1.425, inciso III do CC, que se aplica subsidiariamente à cessão fiduciária de crédito por expressa disposição do parágrafo $4^{\circ}$ do artigo 66-B da Lei de Mercado de Capitais.

Em razão do vencimento antecipado da dívida e da rescisão do contrato principal, poderá o credor-fiduciário utilizar os créditos recebidos para amortizar os valores inadimplidos pelo devedor-fiduciante e, se houver saldo remanescente, o credor-fiduciário deverá creditar o valor correspondente ao devedor-fiduciante. Todavia, se as importâncias 
recebidas dos créditos cedidos fiduciariamente não bastarem para o pagamento integral da dívida e seus encargos, bem como das despesas de cobrança e de administração daqueles créditos, o devedor-fiduciante continuará obrigado a pagar o saldo devedor remanescente, nas condições convencionadas no contrato com o credor-fiduciário.

\subsubsection{Regras Gerais da Cessão Aplicáveis à Cessão Fiduciária de Créditos em Garantia}

Tendo em vista que a cessão fiduciária de crédito em garantia tem por objetivo assegurar o cumprimento de uma obrigação constituída entre devedor e credor, nem todas as regras gerais da cessão serão aplicáveis à cessão fiduciária de créditos em garantia.

Uma das regras gerais da cessão é a de que o devedor poderá opor ao cessionário todas as exceções que lhe era permitido invocar contra o cedente. Todavia, em se tratando de cessão fiduciária de créditos em garantia, o devedor não poderá opor-se ao próprio negócio obrigacional celebrado entre cedente e cessionário (normalmente mútuo), do qual o devedor não é parte.

Com relação à transmissão ou não dos direitos potestativos ao cessionário, Menezes Leitão observa que na cessão de créditos em garantia a questão da transmissão dos direitos potestativos é colocada em especial acuidade, uma vez que a não transmissão dos direitos potestativos pode pôr em risco a garantia, sendo manifesto, no entanto, que o fim da garantia impede o normal exercício desses direitos por parte do cessionário, uma vez que o caráter provisório da transmissão deve levar a que o cessionário se abstenha de exercer esses direitos até que seja seguro que o não cumprimento da obrigação principal irá determinar a cobrança do crédito cedido em garantia. ${ }^{234}$

Pestana de Vasconcelos adota o entendimento de que são transmissíveis os seguintes direitos potestativos: o direito de escolha nas obrigações genéricas e alternativas; o direito de interpelar o devedor para constituí-lo em mora; o direito de, estando o devedor em mora, fixar um prazo razoável para este último cumprir a obrigação, sob pena de a obrigação se considerar para todos os efeitos não cumprida. Todavia, não se transferem,

${ }^{234}$ Cessão de créditos, p. 449. 
entre outros, uma vez que são inseparáveis da condição de titular da posição contratual, o direito à resolução do contrato fonte do crédito cedido, quer por falta de cumprimento do devedor, quer por alteração anormal das circunstâncias em que as partes fundaram a decisão de contratos; o direito de denúncia dos contratos duradouros; o direito de anulação do contrato e de confirmação do negócio jurídico anulável. ${ }^{235}$

O artigo 295 do CC determina que nas cessões a título oneroso o cedente será responsável pela existência do crédito ao tempo em que o cedeu. Todavia, em se tratando de cessão fiduciária de créditos em garantia que tenham por objeto créditos que ainda não se venceram, a garantia da exigibilidade estender-se-á até a data de vencimento do crédito cedido. Significa, portanto, que o cedente responderá pelos fatos posteriores à cessão que possam comprometam o valor jurídico ou a própria existência do crédito (p.ex., anulação do negócio-base que originou o crédito).

Quanto à garantia de solvência do devedor, nos termos do artigo 296 do CC o cedente não responde pela solvência do devedor, exceto se tiver expressamente assumido tal obrigação perante o cessionário. Se tiver assumido tal obrigação, o cedente deverá responder pela solvência do devedor não só no momento da transferência do crédito, como também em sua data de vencimento. Todavia, em se tratando de cessão fiduciária de créditos em garantia, nos parece que a responsabilização do cedente pela solvência do devedor seja condição inerente à própria garantia, caso contrário o credor-fiduciário teria uma garantia frágil e ineficaz em relação ao seu propósito.

\subsubsection{Regras do Penhor Aplicáveis à Cessão Fiduciária de Créditos em Garantia}

O parágrafo $4^{\circ}$ do artigo 66-B da Lei de Mercado de Capitais dispõe expressamente que aplicam-se à cessão fiduciária de direitos sobre coisas móveis ou sobre títulos de crédito certas regras relativas ao penhor de direitos creditórios, mais especificamente as regras contempladas nos artigos 1.421, 1.425, 1.426, 1.435 e 1.436 do CC. Todavia, em razão da diferença entre a natureza jurídica do penhor (direito real de garantia em que o bem empenhado permanece no patrimônio do devedor) e da cessão fiduciária de créditos

${ }^{235}$ A cessão de créditos em garantia e a insolvência: em particular da posição do cessionário na insolvência do cedente, p. 497. 
em garantia (em que há a plena transferência do bem dado em garantia que passa a integrar o patrimônio do credor), há necessidade de que as regras do penhor sejam ajustadas para que possam ser aplicáveis à cessão fiduciária.

A primeira regra do penhor aplicável à cessão fiduciária de créditos em garantia é a constante do artigo 1.421 do $\mathrm{CC}$, que dispõe que o pagamento de uma ou mais prestações da dívida não importa exoneração correspondente da garantia, ainda que esta compreenda vários bens, salvo disposição expressa no título ou na quitação. Esta regra é plenamente aplicável à cessão fiduciária, sem necessidade de quaisquer ajustes. Como salientam Restiffe Neto e Paulo Sérgio Restiffe, trata-se do princípio de indivisibilidade dos direitos reais de garantia que, aqui, atua em segurança do credor titular da garantia fiduciária. ${ }^{236}$

A segunda regra do penhor aplicável à cessão fiduciária de créditos em garantia é a constante do artigo 1.425 do $\mathrm{CC}$, que trata das hipóteses de vencimento antecipado da dívida:

"Art. 1.425. A dívida considera-se vencida:

I - se, deteriorando-se, ou depreciando-se o bem dado em segurança, desfalcar a garantia, e o devedor, intimado, não a reforçar ou substituir;

II - se o devedor cair em insolvência ou falir;

III - se as prestações não forem pontualmente pagas, toda vez que deste modo se achar estipulado o pagamento. Neste caso, o recebimento posterior da prestação atrasada importa renúncia do credor ao seu direito de execução imediata;

IV - se perecer o bem dado em garantia, e não for substituído;

$V$ - se se desapropriar o bem dado em garantia, hipótese na qual se depositará a parte do preço que for necessária para o pagamento integral do credor.

$\S 1^{o}$ Nos casos de perecimento da coisa dada em garantia, esta se sub-rogará na indenização do seguro, ou no ressarcimento do dano, em benefício do credor, a quem assistirá sobre ela preferência até seu completo reembolso.

$\S 2^{\underline{o}}$ Nos casos dos incisos IV e V, só se vencerá a hipoteca antes do prazo estipulado, se o perecimento, ou a desapropriação recair sobre o bem dado em garantia, e esta não abranger outras; subsistindo, no caso contrário, a dívida reduzida, com a respectiva garantia sobre os demais bens, não desapropriados ou destruídos."

${ }^{236}$ Alienação Fiduciária e o Fim da Prisão Civil, p. 95. 
Dentre os cinco incisos do referido artigo 1.425 do $\mathrm{CC}$, entendemos não serem aplicáveis à cessão fiduciária em garantia o incisoV do referido artigo e os parágrafos $1^{\circ} \mathrm{e}$ $2^{\circ}$ do referido artigo por incompatibilidade com o objeto da cessão.

Por outro lado, entendemos aplicáveis à cessão fiduciária, sem restrição, os incisos II e III do artigo 1.425 do CC que tratam, respectivamente, da hipótese de o devedor cair em insolvência ou falir, e da hipótese de as prestações não serem pontualmente pagas, toda vez que deste modo se achar estipulado o pagamento. Para a aplicação dos incisos I e IV à cessão fiduciária, há que se interprar tais dispositivos de maneira mais ampla. Assim, por depreciação e/ou perecimento do bem, imaginamos a hipótese de redução do valor da garantia.

A terceira regra do penhor aplicável à cessão fiduciária de créditos em garantia é a constante do artigo 1.426 do CC, que dispõe que nas hipóteses do artigo 1.425 do CC, de vencimento antecipado da dívida, não se compreendem os juros correspondentes ao tempo ainda não decorrido. Esta regra é clara e não merece qualquer ajuste para ser aplicada à cessão fiduciária de créditos em garantia.

A quarta regra do penhor aplicável à cessão fiduciária de créditos em garantia é a constante do artigo 1.435 do CC, que dispõe sobre as obrigações do credor pignoratício em relação ao bem empenhado:

“Art. 1.435. O credor pignoratício é obrigado:

I - à custódia da coisa, como depositário, e a ressarcir ao dono a perda ou deterioração de que for culpado, podendo ser compensada na dívida, até a concorrente quantia, a importância da responsabilidade;

II - à defesa da posse da coisa empenhada e a dar ciência, ao dono dela, das circunstâncias que tornarem necessário o exercício de ação possessória;

III - a imputar o valor dos frutos, de que se apropriar (art. 1.433, inciso V) nas despesas de guarda e conservação, nos juros e no capital da obrigação garantida, sucessivamente;

IV - a restituí-la, com os respectivos frutos e acessões, uma vez paga a dívida; 
$V$ - a entregar o que sobeje do preço, quando a dívida for paga, no caso do inciso IV do art. 1.433."

As regras constantes do artigo 1.435 acima deverão ser aplicadas naquilo que forem compatíveis com a natureza jurídica da cessão fiduciária de créditos, pois o credorfiduciário não tem a custódia do bem como depositário, mas sim como titular pleno e efetivo, ainda que tal titularidade seja temporária e enquanto perdure a dívida do devedorfiduciante.

A quinta regra do penhor aplicável à cessão fiduciária de créditos em garantia é a constante do artigo 1.436 do CC, que dispõe sobre as hipóteses de extinção do penhor:

“Art. 1.436. Extingue-se o penhor:

I - extinguindo-se a obrigação;

II - perecendo a coisa;

III - renunciando o credor;

$I V$ - confundindo-se na mesma pessoa as qualidades de credor e de dono da coisa;

$V$ - dando-se a adjudicação judicial, a remissão ou a venda da coisa empenhada, feita pelo credor ou por ele autorizada.

$\S 1^{o}$ Presume-se a renúncia do credor quando consentir na venda particular do penhor sem reserva de preço, quando restituir a sua posse ao devedor, ou quando anuir à sua substituição por outra garantia.

$\S 2^{o}$ Operando-se a confusão tão-somente quanto a parte da dívida pignoratícia, subsistirá inteiro o penhor quanto ao resto.”

Da mesma forma, as regras constantes do artigo 1.436 acima deverão ser aplicadas naquilo que forem compatíveis com a natureza jurídica da cessão fiduciária de créditos. Sendo o credor-fiduciário o titular do bem dado em garantia, inaplicáveis as regras previstas no inciso IV e no parágrafo $2^{\circ}$ do artigo 1.436 acima, que tratam da confusão da qualidade de credor e dono da coisa. 
Também inaplicáveis à cessão fiduciária de títulos de crédito as regras previstas no inciso $\mathrm{V}$ e no parágrafo $1^{\circ}$ do artigo 1.436 acima, primeiro porque incompatíveis com o objeto da cessão fiduciária e depois porque na cessão fiduciária de créditos em garantia permite-se que o credor-fiduciário utilize as importâncias recebidas relativas aos créditos cedidos fiduciariamente para amortizar parte ou totalidade da dívida contraída pelo devedor-fiduciante.

Quanto à regra prevista no inciso II do artigo 1.436 do CC sobre o perecimento da coisa, embora possa ser aplicável à cessão fiduciária de crédito em garantia, há que se fazer um certo esforço para identificar-se hipóteses de perecimento de títulos de crédito dados em garantia, ainda mais considerando que é usual que os devedores-fiduciantes permaneçam na posse dos títulos de crédito, transferindo somente o crédito nele incorporado como garantia de suas obrigações perante o credor-fiduciário.

\subsection{Principais Espécies de Cessão Fiduciária com Escopo de Garantia no Brasil}

\subsubsection{Cessão Fiduciária no Âmbito do Mercado Imobiliário}

A cessão fiduciária foi instituída em nosso ordenamento jurídico pela Lei ${ }^{\circ} 4.864$, de 29.11.1965, que criou medidas de incentivo à indústria de construção civil. O artigo 21 da Lei 4.864/1965 permitiu que, nas suas operações de crédito imobiliário, as Caixas Econômicas dessem preferência ao financiamento de projetos da iniciativa privada para a construção e venda a prazo, em edificações, ou conjunto de edificações, de unidades habitacionais de interesse social, ou destinadas às classes de nível médio de renda. Nessas operações, as Caixas Econômicas poderiam financiar o empresário, mediante abertura de crédito a ser por ele utilizado na medida da entrega das unidades habitacionais, admitido-se o contrato prévio de promessa de financiamento. 
Como garantia dos créditos concedidos pelas Caixas Econômicas e pelas sociedades de crédito imobiliário, admitiam-se a caução, a cessão parcial ou a cessão fiduciária dos direitos decorrentes dos contratos de alienação das unidades habitacionais integrantes do projeto financiado.

Na cessão fiduciária em garantia, o credor era titular fiduciário dos direitos cedidos até a liquidação da dívida garantida, continuando o devedor a exercer os direitos em nome do credor, segundo as condições do contrato e com as responsabilidades de depositário.

No caso de inadimplemento da obrigação garantida, o credor fiduciário poderia, mediante comunicação aos adquirentes das unidades habitacionais, passar a exercer diretamente todos os direitos decorrentes dos créditos cedidos, aplicando as importâncias recebidas no pagamento do seu crédito e nas despesas decorrentes da cobrança, e entregando ao devedor o saldo porventura apurado. Se a importância recebida na realização dos direitos cedidos não bastasse para o pagamento do crédito do credor fiduciário, o devedor continuaria pessoalmente obrigado a pagar o saldo remanescente. Para que fosse válida contra terceiros, a cessão fiduciária em garantia deveria ter o seu instrumento, público ou particular, qualquer que seja o seu valor, registrado no Registro de Títulos e Documentos.

A cessão fiduciária de crédito em garantia prevista na Lei $\mathrm{n}^{\circ}$ 4.864/1965 era, portanto, de aplicação restrita, pois somente entidades financeiras integrantes do Sistema Financeiro Habitacional - SFH poderiam atuar como credores fiduciários e somente se admitia esta garantia para o financiamento habitacional.

Posteriormente, a LSFI, que regula o Sistema de Financiamento Imobiliário - SFI, passou a regular integralmente a matéria contemplada na Lei $\mathrm{n}^{\circ} 4.864 / 1965$. A cessão fiduciária de direitos creditórios decorrentes de contratos de alienação de imóveis foi aperfeiçoada e passou a ser utilizada nas operações de financiamento imobiliário em geral realizadas pelas entidades integrantes do SFI. A LSFI também instituiu a alienação fiduciária de bens imóveis. 
O contrato de cessão fiduciária em garantia opera a transferência ao credor da titularidade dos créditos cedidos, até a liquidação da dívida garantida, e conterá, além de outros elementos, os seguintes: (i) o total da dívida ou sua estimativa; (ii) o local, a data e a forma de pagamento; (iii) a taxa de juros; (iv) a identificação dos direitos creditórios objeto da cessão fiduciária.

O artigo 19 da LSFI estabelece os direitos do credor fiduciário, quais sejam: (i) o de conservar e recuperar a posse dos títulos representativos dos créditos cedidos, contra qualquer detentor, inclusive o próprio cedente; intimar os devedores que não paguem ao cedente; (ii) usar das ações, recursos e execuções, judiciais e extrajudiciais, para receber os créditos cedidos e exercer os demais direitos conferidos ao cedente no contrato de alienação do imóvel; e (iii) receber diretamente dos devedores os créditos cedidos fiduciariamente que, após deduzidas as despesas de cobrança e de administração, deverão ser creditadas ao devedor cedente, na operação objeto da cessão fiduciária, até final liquidação da dívida e encargos, responsabilizando-se o credor fiduciário perante o cedente, como depositário, pelo que receber além do que este lhe devia. Se, no entanto, as importâncias recebidas pelo credor fiduciário não bastarem para o pagamento integral da dívida e seus encargos, bem como das despesas de cobrança e de administração daqueles créditos, o devedor continuará obrigado a resgatar o saldo remanescente nas condições convencionadas no contrato.

O artigo 20 da referida lei dispõe que na hipótese de falência do devedor cedente e se não tiver havido a tradição dos títulos representativos dos créditos cedidos fiduciariamente, ficará assegurada ao cessionário fiduciário a restituição na forma da legislação pertinente. Efetivada a restituição, prosseguirá o cessionário fiduciário no exercício de seus direitos na forma do disposto nesta seção.

\subsubsection{Cessã̃o Fiduciária no Âmbito do Mercado Financeiro e de Capitais}

Feitas as considerações sobre a cessão fiduciária em garantia de créditos imobiliários, passaremos a comentar o artigo 66-B da Lei de Mercado de Capitais, com a redação dada pelo artigo 56 da Lei $n^{\circ} 10.931 / 2004$, que introduziu em seu parágrafo 
terceiro a figura da cessão fiduciária de direitos sobre coisas móveis, bem como de títulos de crédito, conforme abaixo:

“Art. 66-B.

(...)

$\$ 3^{\circ}$ É admitida a alienação fiduciária de coisa fungível e a cessão fiduciária de direitos sobre coisas móveis, bem como de títulos de crédito, hipóteses em que, salvo disposição em contrário, a posse direta $e$ indireta do bem objeto da propriedade fiduciária ou do título representativo do direito ou do crédito é atribuído ao credor, que, em caso de inadimplemento ou mora da obrigação garantida, poderá vender a terceiros o bem objeto da propriedade fiduciária independente de leilão, hasta pública ou qualquer outra medida judicial ou extrajudicial, devendo aplicar o preço da venda no pagamento do seu crédito e das despesas decorrentes da realização da garantia, entregando ao devedor o saldo, se houver, acompanhado do demonstrativo da operação realizada.” (grifo nosso)

Na cessão fiduciária de crédito, opera-se a transferência da titularidade dos créditos do cedente ao cessionário como garantia de um empréstimo concedido pelo cessionário (credor fiduciário) ao cedente (devedor fiduciante), até o pagamento integral da dívida pelo devedor-fiduciante.

Antes da edição da Lei $n^{\circ} 10.931 / 2004$, o parágrafo $6^{\circ}$ do artigo 66 revogado vedava o pacto comissório, tornando nula a cláusula que autorizasse o proprietário fiduciário a ficar com a coisa alienada em garantia, se a dívida não fosse paga no seu vencimento.

Todavia, a atual redação do artigo 66-B da Lei de Mercado de Capitais dada pela Lei $\mathrm{n}^{\circ} 10.931 / 2004$ não veda o pacto comissório e, portanto, em caso de mora ou inadimplemento do devedor-fiduciante, o credor-fiduciário fica autorizado a utilizar as importâncias recebidas dos créditos cedidos fiduciariamente para abater as parcelas vencidas da dívida.

Como se vê, os créditos cedidos fiduciariamente passam a ser de titularidade do credor-fiduciário, sendo esta titularidade condicionada e limitada ao escopo para a qual foi constituída. Em razão da transferência de titularidade dos créditos cedidos fiduciariamente, resta analisar o tratamento a ser dado aos referidos créditos nas hipóteses de recuperação judicial e/ou falência do devedor-fiduciante, o que será feito no Capítulo IV deste trabalho. 


\subsubsection{Cessão Fiduciária de Quotas de Fundo de Investimento para Garantia de Locação Imobiliária}

A Lei ${ }^{\circ}$ 11.196, de 21.11.2005 admite a cessão fiduciária de quotas de fundo de investimento para a garantia de locação imobiliária. $\mathrm{O}$ artigo 88 da referida lei dispõe que as instituições autorizadas pela Comissão de Valores Mobiliários - CVM para o exercício da administração de carteira de títulos e valores mobiliários ficam autorizadas a constituir fundos de investimento que permitam a cessão de suas quotas em garantia de locação imobiliária.

A referida cessão será formalizada, mediante registro perante o administrador do fundo, pelo titular das quotas, por meio de termo de cessão fiduciária acompanhado de 1 (uma) via do contrato de locação, constituindo, em favor do credor fiduciário, propriedade resolúvel das quotas. Na hipótese de o cedente não ser o locatário do imóvel locado, deverá também assinar o contrato de locação ou aditivo, na qualidade de garantidor.

A cessão em garantia de que trata o caput do artigo 88 da referida lei constitui regime fiduciário sobre as quotas cedidas, que ficam indisponíveis, inalienáveis e impenhoráveis, tornando-se a instituição financeira administradora do fundo seu agente fiduciário. O contrato de locação mencionará a existência e as condições da cessão de que trata o caput deste artigo, inclusive quanto a sua vigência, que poderá ser por prazo determinado ou indeterminado. Na hipótese de prorrogação automática do contrato de locação, o cedente permanecerá responsável por todos os seus efeitos, ainda que não tenha anuído no aditivo contratual, podendo, no entanto, exonerar-se da garantia, a qualquer tempo, mediante notificação ao locador, ao locatário e à administradora do fundo, com antecedência mínima de 30 (trinta) dias.

Na hipótese de mora, o credor fiduciário notificará extrajudicialmente o locatário e o cedente, se pessoa distinta, comunicando o prazo de 10 (dez) dias para pagamento integral da dívida, sob pena de excussão extrajudicial da garantia. Não ocorrendo o pagamento integral da dívida no prazo de $10(\mathrm{dez})$ dias, o credor poderá requerer ao agente 
fiduciário que lhe transfira, em caráter pleno, exclusivo e irrevogável, a titularidade de quotas suficientes para a sua quitação, sem prejuízo da ação de despejo e da demanda, por meios próprios, da diferença eventualmente existente, na hipótese de insuficiência da garantia. A excussão indevida da garantia enseja responsabilidade do credor fiduciário pelo prejuízo causado, sem prejuízo da devolução das quotas ou do valor correspondente, devidamente atualizado.

\subsubsection{Cessão Fiduciária no Âmbito das Concessões Públicas}

A Lei no 8.987, de 13.02.1995 dispõe sobre o regime de concessão e permissão da prestação de serviços públicos previsto no art. 175 da Constituição Federal.

A cessão fiduciária de créditos passou a ser admitida com a introdução do artigo 28-A na Lei $\mathrm{n}^{\circ} 8.987 / 1995$ pela Lei $\mathrm{n}^{\circ} 11.196$, de 21.12.2005:

"Art. 28-A Para garantir contratos de mútuo de longo prazo, destinados a investimentos relacionados a contratos de concessão, em qualquer de suas modalidades, as concessionárias poderão ceder ao mutuante, em caráter fiduciário, parcela de seus créditos operacionais futuros, observadas as seguintes condições:

I - o contrato de cessão dos créditos deverá ser registrado em Cartório de Títulos e Documentos para ter eficácia perante terceiros;

II - sem prejuízo do disposto no inciso I do caput deste artigo, a cessão do crédito não terá eficácia em relação ao Poder Público concedente senão quando for este formalmente notificado;

III - os créditos futuros cedidos nos termos deste artigo serão constituídos sob a titularidade do mutuante, independentemente de qualquer formalidade adicional;

IV - o mutuante poderá indicar instituição financeira para efetuar a cobrança $e$ receber os pagamentos dos créditos cedidos ou permitir que a concessionária o faça, na qualidade de representante e depositária;

$V$ - na hipótese de ter sido indicada instituição financeira, conforme previsto no inciso IV do caput deste artigo, fica a concessionária obrigada a apresentar a essa os créditos para cobrança;

VI - os pagamentos dos créditos cedidos deverão ser depositados pela concessionária ou pela instituição encarregada da cobrança em conta corrente bancária vinculada ao contrato de mútuo;

VII - a instituição financeira depositária deverá transferir os valores recebidos ao mutuante à medida que as obrigações do contrato de mútuo tornarem-se exigíveis;

$e$ 
VIII - o contrato de cessão disporá sobre a devolução à concessionária dos recursos excedentes, sendo vedada a retenção do saldo após o adimplemento integral do contrato.

Parágrafo único. Para os fins deste artigo, serão considerados contratos de longo prazo aqueles cujas obrigações tenham prazo médio de vencimento superior a 5 (cinco) anos."

\subsubsection{Cessão Fiduciária em Garantia de Direitos Creditórios do Agronegócio}

A Lei $\mathrm{n}^{\mathrm{o}}$ 11.076, de 30.12.2002 dispõe, dentre outros assuntos, sobre o Certificado de Depósito Agropecuário - CDA, o Warrant Agropecuário - WA, o Certificado de Direitos Creditórios do Agronegócio - CDCA, a Letra de Crédito do Agronegócio - LCA e o Certificado de Recebíveis do Agronegócio - CRA.

O artigo 41 da referida lei permite a cessão fiduciária em garantia de direitos creditórios do agronegócio em favor dos adquirentes do Certificado de Direitos Creditórios do Agronegócio CDCA, da Letra de Crédito do Agronegócio - LCA e do Certificado de Recebíveis do Agronegócio - CRA, aplicando-se a este tipo de cessão fiduciária o disposto nos artigos 18 a 20 da LSFI.

Em suma, existem atualmente em nosso ordenamento jurídico pelo menos 5 (cinco) formas de cessão fiduciária com o escopo de garantia, sendo a primeira destinada à garantia de créditos decorrentes de financiamento imobiliário; a segunda destinada à garantia de créditos decorrentes de financiamento concedido por instituições financeiras devidamente autorizadas a funcionar pelo Banco Central do Brasil; a terceira é a cessão fiduciária de quotas de fundo de investimento destinada a garantia de locação imobiliária; a quarta destinada a garantir contratos de mútuo de longo prazo, destinados a investimentos relacionados a contratos de concessão e, por fim, a cessão fiduciária em garantia de direitos creditórios do agronegócio.

Frise-se, desde já, que o escopo da presente dissertação é analisar o segundo tipo de cessão fiduciária em garantia, isto é, a cessão fiduciária destinada à garantia de créditos decorrentes de empréstimos concedidos por instituições financeiras no âmbito do mercado financeiro e de capitais. 


\subsection{Sujeitos do Contrato de Cessão Fiduciária no Âmbito do Mercado Financeiro e de Capitais}

Os sujeitos do contrato de cessão fiduciária de crédito celebrado no âmbito do mercado financeiro e de capitais são o cedente (devedor-fiduciante) e o cessionário (credor-fiduciário). O cedente poderá ser qualquer pessoa física ou jurídica que tenha a intenção de ceder créditos para garantir uma operação financeira, sendo a mais usual o empréstimo, enquanto o cessionário deverá ser necessariamente uma instituição financeira devidamente autorizada a funcionar pelo Banco Central do Brasil.

\subsection{O Objeto do Contrato de Cessão Fiduciária no Âmbito do Mercado Financeiro e de Capitais}

Nos termos do disposto no parágrafo $3^{\circ}$ do art. 66-B da Lei de Mercado de Capitais, constituem objeto do contrato de cessão fiduciária no âmbito do mercado financeiro e de capitais os direitos sobre coisas móveis e títulos de crédito.

\subsubsection{Cessão de Direitos sobre Coisas Móveis}

Dentre os direitos sobre coisas móveis que são objeto de interesse de nosso estudo, destacamos os direitos de crédito, que são passíveis de cessão fiduciária como forma de garantia de uma obrigação principal assumida entre devedor-fiduciante e credor-fiduciário.

Conforme bem observa Oscar Barreto Filho, não é pacífica a conceituação de bem e de coisa na doutrina de modo a permitir que se estabeleça, com rigor técnico, sua distinção. Admite-se geralmente que a noção de bem é mais ampla, e que a relação entre bem e coisa é do gênero para a espécie. Sob o ângulo jurídico, bens são valores materiais ou imateriais, 
que podem ser objeto de uma relação de direito. Compreendem, no seu significado, coisas corpóreas e incorpóreas, fatos e abstenções humanas (obrigações). ${ }^{237}$

Caio Mario da Silva Pereira observa que os bens, especificamente considerados, distinguem-se das coisas, em razão da materialidade destas: as coisas são materiais ou concretas, enquanto se reserva para designar os imateriais ou abstratos o nome bens em sentido estrito. Uma casa, uma animal de tração são coisas, porque concretizado cada um em uma unidade material e objetiva, distinta de qualquer outra. Um direito de crédito, uma faculdade, embora defensável ou protegível pelos remédios jurídicos postos à disposição do sujeito em caso de lesão, diz-se, com maior precisão, ser um bem. ${ }^{238}$

Os bens móveis são aqueles suscetíveis de movimento próprio, ou de remoção por força alheia, sem alteração da substância ou da destinação econômico-social, nos termos do artigo 82 do CC. $\mathrm{O}$ artigo 83 do CC define os bens móveis que são assim considerados por força de lei: (i) as energias que tenham valor econômico; (ii) os direitos reais sobre objetos móveis e as ações correspondentes; e (iii) os direitos pessoais de caráter patrimonial e as respectivas ações.

Orlando Gomes diz que, para os efeitos legais, certos bens incorpóreos consideramse móveis (os direitos de crédito, os direitos reais sobre objetos móveis, os direitos intelectuais e as ações correspondentes). ${ }^{239}$ Caio Mário diz que são bens móveis, ex vi legis, os direitos de crédito com caráter patrimonial (como as ações respectivas), merecendo censura neste passo o Código, ao denominá-los direitos pessoais, uma terminologia superada e hoje tida por inadequada. ${ }^{240}$ Assim, tendo em vista que o crédito é um direito pessoal de caráter patrimonial, não há dúvida que o crédito é considerado bem móvel por força de lei.

O crédito exerce um papel extremamente importante nas operações comerciais, pois permite que uma pessoa utilize os créditos recebidos no presente, com a obrigação futura de pagar pelo que recebeu. Fran Martins define o crédito como a confiança que uma pessoa

\footnotetext{
${ }^{237}$ Teoria do Estabelecimento Comercial: fundo de comércio ou fazenda mercantil, $2^{\mathrm{a}}$ ed., p. 32.

${ }^{238}$ Instituições de Direito Civil, v.1, $21^{\mathrm{a}}$ ed., p. 401.

${ }^{239}$ Introdução ao Direito Civil, $11^{\mathrm{a}}$ ed., p. 220.

${ }^{240}$ Instituições de Direito Civil, v. 1, $21^{\text {a }}$ ed., p. 425.
} 
inspira a outra de cumprir, no futuro, obrigação atualmente assumida. ${ }^{241}$ Da mesma forma, Carvalho de Mendonça observa que na expressão crédito se acha sempre a idéia de confiança, aplicada aos negócios. Quem presta uma coisa para receber outra em determinado ou determinável tempo futuro denota confiar no devedor, já em virtude das condições pessoais deste, já em virtude das garantias reais por ele oferecidas. ${ }^{242}$

João Eunápio Borges também observa que na noção de crédito estão implícitos a confiança, ou seja, quem aceita, em troca de sua mercadoria ou de seu dinheiro, a promessa de pagamento futuro, confia no devedor, porém tal confiança não pode repousar exclusivamente no devedor, mas em garantias pessoais (aval, fiança) ou reais (penhor, hipoteca, etc.) que ele ofereça em segurança da oportuna realização da prestação futura a que se obrigou; e também o tempo, constituindo o prazo o intervalo, o período que medeia entre a prestação presente e atual e a prestação futura. ${ }^{243}$

\subsubsection{Cessão de Títulos de Crédito}

Os títulos de crédito têm grande importância na economia moderna, pois foram os instrumentos criados para dar maior certeza, segurança e rapidez na transferência do crédito, visto que a circulação do crédito seria impraticável se os direitos de crédito permanecessem ligados aos sujeitos originários do negócio-base da cessão, pois o direito do cedente é passível de exceções.

Como bem salienta Uinie Caminha, na cessão de crédito há uma certa insegurança do adquirente sobre o conteúdo de sua aquisição, pois o crédito diz respeito a determinado negócio do qual o cessionário não participou, não tendo, assim, conhecimento de todas as suas peculiaridades e, por conseguinte, das exceções que lhe possam ser opostas. Esta é a principal causa das dificuldades enfrentadas na circulação dos créditos por meio de instrumentos que não delimitam exatamente o conteúdo do que está sendo posto em circulação. Os títulos de crédito vieram suprir a necessidade econômica de segurança e rapidez na transmissão de créditos, com sua objetivação, delimitação e incorporação em

\footnotetext{
${ }^{241}$ Títulos de crédito, v. 1, p. 3.

${ }^{242}$ Tratado de Direito Comercial Brasileiro, v. V, Livro III, Parte II, p., 49.

${ }^{243}$ Títulos de crédito, p. 1.
} 
um instrumento que pode circular, submetido às regras relativas à circulação das coisas móveis, e que carrega consigo o conteúdo perfeitamente especificado do direito nele incorporado. $^{244}$

Os títulos de crédito surgiram na Idade Média, com algumas das características que possuem hoje, muito mais como fruto das necessidades momentâneas de caráter mercantil do que como um procedimento visando especialmente à solução de um problema jurídico. Naquela época, começaram a aparecer de maneira mais freqüente e completa documentos que representavam direitos de crédito, a princípio direitos que poderiam ser utilizados apenas pelos que figuravam nos documentos como seus titulares (credores) e posteriormente passaram a ser transferidos por esses titulares a outras pessoas que, de posse dos documentos podiam exercer, como proprietários, os direitos mencionados nos papéis. $^{245}$

\subsubsection{Principais Características dos Títulos de Crédito}

Na definição clássica de Vivante, título de crédito é o documento necessário para o exercício do direito literal e autônomo nele mencionado. ${ }^{246}$ A partir dessa definição é possível extrair-se alguns dos principais elementos que caracterizam o título de crédito.

Primeiramente, o título de crédito é um documento escrito (cártula) indispensável ao exercício do direito literal nele contido. Bulgarelli anota que a expressão cartularidade ou direito cartular (de chartula, do baixo latim) é empregada para significar tanto a incorporação do direito ao documento, como o direito decorrente do título em relação ao negócio fundamental. ${ }^{247}$

Com o avanço da tecnologia, há uma tendência à desmaterialização do título de crédito com a consequente flexibilização do princípio da cartularidade, já que alguns deles (principalmente a duplicata e outros títulos escriturais) já vêm sendo emitidos eletronicamente há algum tempo.

\footnotetext{
${ }^{244}$ Securitização, p. 85.

${ }^{245}$ Fran Martins, Títulos de Crédito, v. 1, p. 5.

${ }^{246}$ Trattato di diritto commerciale, $5^{\mathrm{a}}$ ed., v. III, p. 123. Importante notar que essa definição foi também adotada pelo Código Civil Brasileiro, em seu artigo 887.

${ }^{247}$ Títulos de Crédito, $12^{\mathrm{a}}$ ed., p. 58.
} 
Uinie Caminha observa que não se pode considerar absoluta a incorporação do direito à cártula, visto que, assim procedendo, estar-se-ia pondo de lado a função instrumental do título em relação ao direito que ele faz circular. Se de outra forma fosse, estaria circulando um título que só carregaria consigo seu valor intrínseco ou, por outro lado, ocorreria o perecimento do direito pelo mero perecimento do título, podendo-se vizualizar essa situação no caso do título destruído ou anulado. Assim, percebe-se que a incorporação não é absoluta, pois o direito incorporado não desaparece com o título que o faz circular. Desaparece apenas a tutela diferenciada oferecida pelo direito, quando o crédito é incorporado em um documento cartular. Para fundamentar sua opinião, a referida autora cita o disposto no artigo 888 do CC, que determina que a omissão de qualquer requisito legal, que tire do escrito a sua validade como título de crédito, não implica a invalidade do negócio jurídico que lhe deu origem. ${ }^{248}$

Entende-se por literalidade o fato de só valer o que está escrito no título. Ascarelli observa que a literalidade age em duas direções, que podem dizer-se positiva e negativa, isto é, contra ou a favor do subscritor. O subscritor não poderá opor nenhuma exceção decorrente de uma convenção não constante do próprio título. O portador, por seu turno, não pode ter, no exercício do direito, pretensões mais amplas que as permitidas pelo teor do documento, ou socorrer-se de elementos extracartulares, a não ser invocando uma distinta convenção entre ele e o devedor. ${ }^{249}$

A autonomia é um dos principais requisitos para circulação dos títulos de crédito, pois o seu adquirente passa a ser titular do direito autônomo, independente da relação anterior entre os possuidores, não sujeitando-se, assim, às exceções oponíveis ao cedente e/ou ao credor originário. Ascarelli distingue dois significados possíveis para a palavra "autonomia", em um deles quer-se afirmar que não podem ser opostas ao subsequente titular do direito cartular as exceções oponíveis ao portador anterior, decorrentes de convenções extra-cartulares, inclusive, nos títulos abstratos, as causais. Em um outro significado, quer-se afirmar que não pode ser oposta ao terceiro possuidor do título a falta de titularidade de quem lho transferiu. ${ }^{250}$

\footnotetext{
${ }^{248}$ Securitização, p. 86.

${ }^{249}$ Teoria Geral dos Títulos de Crédito, traduzido por Nicolau Nazo, p. 52.

${ }^{250}$ Teoria Geral dos Títulos de Crédito, traduzido por Nicolau Nazo, p. 278.
} 
Além dos requisitos essenciais constantes da definição de título de crédito trazida por Vivante, a doutrina acrescenta, ainda, outros dois princípios que podem ou não ocorrer em determinados títulos de crédito: a abstração e a independência. Segundo Fran Martins, a abstração significa que os direitos decorrentes do título não dependem do negócio que deu lugar ao nascimento do título. Desta forma, uma vez emitido o título, ele liberta-se de sua causa, não podendo ser alegada futuramente para invalidar os obrigações decorrentes do título. ${ }^{251}$ A independência do título de crédito caracteriza-se pelo título bastar-se a si mesmo, sem necessidade de outro documento para completá-lo. ${ }^{252}$

Os títulos de crédito podem ser classificados quanto à sua circulação em: (i) títulos nominativos, cuja circulação se faz mediante um termo de cessão ou de transferência. Trazem esses títulos o nome da pessoa indicada como beneficiária da prestação a ser realizada. Esses títulos são na sua maioria caracterizados como títulos impróprios, isto é, não derivados de operações de crédito, sendo que vários autores negam-lhes a natureza de títulos de crédito. Os títulos nominativos devem, em sua maioria, constar do registro do emitente (ex. ações nominativas); (ii) títulos à ordem, que trazem sempre o nome do beneficiário; e (iii) títulos ao portador, em que o nome do beneficiário não é expressamente mencionado no título. Será considerado titular do título a pessoa com que ele se apresentar. ${ }^{253}$

A doutrina também divide os títulos de crédito de acordo com a natureza dos créditos nele incorporados em: (i) títulos próprios, que representam uma verdadeira operação de crédito (ex. letra de câmbio e nota promissória); (ii) títulos impróprios, que não representam uma verdadeira operação de crédito mas que, revestidos de certos requisitos dos títulos de crédito propriamente ditos, circulam com as garantias que caracterizam esses papéis (ex. cheque); (iii) títulos de legitimação, por muitos incluídos entre os títulos de crédito impróprios, são aqueles que dão ao seu portador não um direito de crédito propriamente dito, mas o de receber uma prestação de coisas ou de serviços (ex.

\footnotetext{
${ }^{251}$ Títulos de Crédito, v. 1, p. 13.

${ }^{252}$ Waldirio Bulgarelli, Títulos de Crédito, p. 60.

${ }^{253}$ Fran Martins, Títulos de Crédito, v. 1, p. 20-24.
} 
bilhetes de espetáculos, passagem, conhecimento de frete ou de depósito); e (iv) títulos de participação, que dão ao portador um direito de participação (ex. ações). ${ }^{254}$

Os títulos de crédito também podem ser classificados quanto à relação fundamental em abstratos e causais. Os títulos abstratos são aqueles em que a causa não foi mencionada no título de crédito, tornando-o completamente abstrato em relação ao negócio fundamental que lhe deu origem. Exemplo típico são as letras de câmbio e a nota promissória, nos quais não é necessário mencionar-se a razão, a causa da sua emissão ou criação, não podendo por isso mesmo serem opostas exceções ao credor com base nela. Já os títulos causais têm uma causa necessária, pois existem em função de um determinado negócio fundamental. Exemplo típico é a duplicata, que só pode ser emitida em função de uma entrega efetiva de mercadorias, ou de um efetivo serviço prestado. ${ }^{255}$

\subsubsection{Dos Títulos de Crédito como Bens Móveis}

Orlando Gomes ensina que entre os bens artificialmente móveis, incluem-se os títulos de crédito. São valores mobiliários nos quais o direito que representam está incorporado ao documento que o consubstancia (título). Confundem-se a tal ponto que muitos consideram o título em si um coisa. ${ }^{256}$

Da mesma forma, Ascarelli admite que o título de crédito pode ser objeto de propriedade por ser uma "coisa". ${ }^{257}$ Carvalho de Mendonça considera os títulos de crédito, quanto à sua negociabilidade, como coisas móveis corpóreas. ${ }^{258}$ Por sua vez, Caio Mário classifica os títulos de crédito na classe dos bens móveis incorpóreos. ${ }^{259}$

Desta forma, é entendimento dominante da doutrina que os títulos de crédito são considerados bens móveis.

\footnotetext{
${ }^{254}$ Ibid., p. 26-29.

${ }^{255}$ Waldirio Bulgarelli, Títulos de Crédito, p. 60.

${ }^{256}$ Introdução ao Direito Civil, $11^{\mathrm{a}}$ ed., p. 220.

${ }^{257}$ Teoria Geral dos Títulos de Crédito, traduzido por Nicolau Nazo, p. 274.

${ }^{258}$ Tratado de Direito Comercial Brasileiro, v. V, Livro III, Parte II, p. 53

${ }^{259}$ Instituições de Direito Civil, v. 1, 21 ${ }^{\mathrm{a}}$ ed., p. 425.
} 


\subsubsection{Do Endosso}

Segundo Asquini, a legitimação é o poder de dispor e gozar do direito que compete ao titular. Tratando-se de títulos de crédito, o conceito de legitimação é técnico e particular: é o poder de fato de exercitar o direito cartular (e dele dispor), fundado sobre as formas de posse estabelecidas pela lei, ainda que a propriedade e a titularidade do título não pertençam efetivamente ao possuidor. Em outras palavras, a lei criou, com o título de crédito, um dispositivo jurídico particular, pelo qual, de um lado, a posse qualificada do título é condição necessária para o exercício do direito e, de outro, é também condição suficiente para o exercício do direito. ${ }^{260}$

Para o referido autor, a titularidade do direito depende de sua propriedade, enquanto a legitimação para o exercício do direito depende de sua posse. Ele define titularidade como sendo a propriedade substancial do direito cartular a um determinado sujeito ("l'appartenenza sostanziale del diritto cartolare a un determinatto soggetto"), enquanto legitimação seria o poder de exercício do próprio direito, combinado a uma certa situação formal, prescindindo da titularidade do direito ("il potere di esercizio del diritto stesso, colegatto ad una data situazione formale (investitura), prescindendo dalla appartenenza del diritto"). Dependendo do regime de circulação a que se submete o título, a posse poderá ser simples ou qualificada. Com efeito, nos títulos ao portador, a posse pura e simples já qualifica e legitima o possuidor ao exercício do direito nele contido. No caso dos títulos à ordem e nominativos, essa posse deve ser qualificada, ou seja, necessita de outras formalidades além da mera tradição para que o título seja transferido validamente. Continua o referido autor dizendo que titularidade e legitimação podem separar-se. O titular de um direito cartular pode não estar legitimado a exercer o direito (por ex., o adquirente do título à ordem, numa cessão sem endosso), e alguém legitimado ao exercício do direito pode não ser o titular (por ex., o possuidor de má-fé). ${ }^{261}$

Ascarelli ensina que os títulos ao portador transferem-se pela simples tradição. Nos títulos à ordem é sempre necessária a tradição, mas é também indispensável o endosso e, portanto, somente será legitimado o possuidor do título que o seja em virtude de uma série

\footnotetext{
260 Titoli di Credito $e$ in Particolare Cambiale e Titolo Bancari Di Pagamento: Lezioni di Diritto Commerciale, pp. 48 e 49.

${ }^{261}$ Ibid., p. 49.
} 
regular de endossos. A transferência que se realiza em virtude do endosso não se refere, portanto, ao direito, mas ao título e, por essa razão, o endosso somente pode ser considerado como requisito necessário para a transferência da posse do título. Todavia, esclarece Ascarelli, para que o possuidor se torne proprietário do título é necessária a existência de outros requisitos indispensáveis à aquisição da propriedade das coisas móveis. Assim, não é, pois, impossível que a transmissão do título, embora com endosso próprio, não se faça com o fim de transferir a propriedade. Nessa hipótese, o possuidor não será proprietário e não será, pois, titular do direito cartular. Legitimado, embora, como proprietário, por força da posse do título e do endosso próprio, não é proprietário e, portanto, desde que isso se demonstre no caso concreto, não poderá mais exercer em próprio nome o direito cartular. ${ }^{262}$

Consiste o endosso na simples assinatura do proprietário ou do mandatário com poderes especiais no verso ou anverso do título, indicando ou não o beneficiário do título. Sendo obrigatório o endosso no verso do título quando se tratar de endosso em branco, isto é, endosso que contém apenas a assinatura do endossante. Como bem assevera Fran Martins, com o endosso em branco o título passa a assemelhar-se a um título ao portador, podendo o seu detentor transferi-lo a qualquer pessoa mediante a simples tradição manual, considerando-se legítimo proprietário do título aquele que a detiver, nos termos o artigo 16 da Lei Uniforme. ${ }^{263} \mathrm{O}$ endosso em branco distingue-se do endosso em preto, também chamado de endosso pleno, completo ou nominativo, que é aquele que contém a designação do beneficiário.

Tanto o Decreto $\mathrm{n}^{\mathrm{o}} 2.044$, de 31.12.1908 (art. $8^{\circ}$, parágrafo $3^{\circ}$ ), como a Lei Uniforme, em seu artigo 12, consideram nulo o endosso parcial. Quem endossa o título é denominado endossante ou endossador e o beneficiário é denominado endossatário.

O endossatário, ao receber o título, torna-se proprietário dos direitos de crédito nele incorporados e, como bem assevera Bulgarelli, inaugura a cadeia de endossos, que deverá ser seguida rigorosamente, no caso de endosso completo, sucedendo-se a cada nome do endossatário o do endossatário seguinte, razão pela qual dispõe o artigo 39 do Decreto $\mathrm{n}^{\circ}$ 2.044/1908, que o "último endossatário é considerado legítimo proprietário da letra

${ }^{262}$ Teoria Geral dos Títulos de Crédito, traduzido por Nicolau Nazo, p. 312-313 e 323.

${ }^{263}$ Títulos de Crédito, v. 1, p. 158. 
endossada em preto, se o primeiro endosso estiver assinado pelo tomador e cada um dos outros, pelo endossatário do endosso imediatamente anterior. Seguindo-se ao endosso em branco outro endosso, presume-se haver o endossador deste adquirido por aquele a propriedade da letra." 264

O Decreto $n^{\circ}$ 2.044/1908 não exigia que o endosso fosse datado. Todavia, alguns doutrinadores já posicionavam-se a favor da inserção da data no endosso ${ }^{265}$, já que nos termos do parágrafo $2^{\circ}$ do artigo $8^{\circ}$ do Decreto 2.044/1908 o endosso posterior ao vencimento de um título de crédito teria efeito de cessão civil. Todavia, a Lei Uniforme, em seu artigo 20, dispôs de modo diverso: "o endosso posterior ao vencimento tem os mesmos efeitos que o endosso anterior. Todavia o endosso posterior ao protesto por falta de pagamento, ou feito depois de expirado o prazo fixado para se fazer o protesto, produz apenas os efeitos de uma cessão ordinária de créditos. Salvo prova em contrário, presume-se que um endosso sem data, foi feito antes de expirado o prazo fixado para se fazer o protesto."

Significa dizer, portanto, que para os fins da Lei Uniforme, a data do endosso só será necessária para os endossos feitos posteriormente ao protesto por falta de pagamento ou feitos depois de expirado o prazo fixado para se fazer o protesto, pois nesses casos a Lei Uniforme considera que o endosso produzirá apenas efeitos de uma cessão ordinária de créditos. Por efeitos de cessão ordinária de créditos tem-se que o endossante não é solidariamente responsável pelo aceite e pelo pagamento do título. Além disso, o endossatário passaria a estar sujeito às exceções que poderiam ser opostas pelo endossante, com base na regra prevista no artigo 294 do CC: "o devedor pode opor ao cessionário as exceções que lhe competirem, bem como as que, no momento em que veio a ter conhecimento da cessão, tinha contra o cedente."

Com relação à responsabilidade do endossante pela aceitação e pagamento do título, o artigo 44, incisos I e IV do Decreto n 2.044/1908 não admitia cláusulas restritivas da responsabilidade do endossante, considerando-as como não escritas. A Lei Uniforme, em seu artigo 15, dispôs em sentido diverso, admitindo o endosso com a cláusula

\footnotetext{
${ }^{264}$ Títulos de Crédito, $12^{\mathrm{a}}$ ed., p. 166.

${ }^{265}$ Cf. Carvalho de Mendonça, Tratado de Direito Comercial Brasileiro, v. V, Livro III, Parte II, nº 684, p. 278; Fran Martins, Títulos de Crédito, v. 1, p. 176.
} 
excludente da garantia do endossante quanto à aceitação e ao pagamento da letra, assim com admitiu a possibilidade de o endossante proibir novo endosso e, neste caso, o endossante não garantirá o pagamento às pessoas a quem a letra for posteriormente endossada.

A doutrina acabou por reconhecer e adotar algumas espécies de endosso, a saber:

(i) Endosso-mandato, procuração: é aquele pelo qual não se transfere a propriedade do título, outorgando-se apenas poderes ao mandatário para agir em nome do proprietário do título. O artigo 18 da Lei Uniforme dispõe que "quando o endosso contém a menção "valor a cobrar" (valeur en recouvrement), "para cobrança" (pour encaissement), "por procuração" (par procuration), ou qualquer outra menção que implique um simples mandato, o portador pode exercer todos os direitos emergentes da letra, mas só pode endossá-la na qualidade de procurador. Os coobrigados, neste caso, só podem invocar contra o portador as exceções que eram oponíveis ao endossante. O mandato que resulta de um endosso por procuração não se extingue por morte ou sobrevinda incapacidade legal do mandatário."

(ii) Endosso-pignoratício ou endosso-garantia: está previsto no artigo 19 da Lei Uniforme, que assim dispõe: "quando o endosso contém a menção "valor em garantia", "valor em penhor" ou qualquer outra menção que implique uma caução, o portador pode exercer todos os direitos emergentes da letra, mas um endosso feito por ele só vale como endosso a título de procuração. Os coobrigados não podem invocar contra o portador as exceções fundadas sobre as relações pessoais deles com o endossante, a menos que o portador, ao receber a letra, tenha procedido conscientemente em detrimento do devedor.”

Ascarelli observa que no negócio fiduciário o endossatário se torna titular do respectivo direito, embora responsável obrigacionalmente perante o endossador, daí porque de um lado inoponíveis as exceções contra o endossatário e, de outro, o direito de os terceiros credores do endossatário considerarem o título como parte do patrimônio deste. 
Observa o referido autor que a transmissão fiduciária da propriedade do título para garantia é freqüente no conhecimento marítimo. É hábito constante o de transmitir, com endosso próprio, o conhecimento marítimo ao banco que abre o crédito para a compra da mercadoria. O banco, nesta hipótese, torna-se, proprietário fiduciário do título (e da mercadoria), isto é, por um lado, adquire a propriedade, mas por outro, se obriga a retransmitir o conhecimento desde que seja integralmente satisfeito o seu crédito. ${ }^{266}$

\subsection{Formalização do Contrato de Cessão Fiduciária}

A cessão fiduciária deverá constituir-se por meio de contrato escrito celebrado entre cedente e cessionário e assinado por duas testemunhas, que deverá conter, além dos requisitos previstos no $\mathrm{CC}$, pelo menos as seguintes informações exigidas pelo artigo 18 da LSFI: (i) o total da dívida ou sua estimativa; (ii) o local, a data e a forma de pagamento; (iii) a taxa de juros; e (iv) a identificação dos direitos creditórios objeto da cessão fiduciária.

Quanto ao registro do contrato de cessão fiduciária no Registro de Títulos e Documentos, dúvida existe em saber se há necessidade do referido registro e, em caso afirmativo, se ele seria feito apenas para dar publicidade a terceiros da existência do contrato de cessão fiduciária ou se seria condição necessária para que referido contrato tenha efeito constitutivo entre as próprias partes.

Isto porque, enquanto o artigo 1.361 , parágrafo $1^{\circ}$ do $\mathrm{CC}$, que trata da propriedade fiduciária geral, determina que a propriedade fiduciária constitui-se com o registro do contrato, celebrado por instrumento público ou particular, que lhe serve de título no Registro de Títulos e Documentos, o artigo 66-B da Lei de Mercado de Capitais nada dispõe acerca da necessidade de registro do contrato de cessão fiduciária no Registro de Títulos e Documentos. É certo que o revogado artigo 66 da Lei de Mercado de Capitais previa o registro do contrato para produzir efeitos em relação a terceiros.

${ }^{266}$ Teoria Geral dos Títulos de Crédito, traduzido por Nicolau Nazo, p. 325 e nota (3). 
A doutrina diverge em relação ao tema. Parte dela entende que a regra prevista no artigo 1.361, parágrafo $1^{\circ}$ do CC não se aplica à propriedade fiduciária prevista na Lei de Mercado de Capitais e, portanto, o registro do contrato deverá ser feito no Registro de Títulos e Documentos somente para dar publicidade a terceiros. Este é o entendimento adotado por Paulo Restiffe Neto e Paulo Sérgio Restiffe, Jean Carlos Fernandes e Melhim Namem Chalhub, conforme adiante será demonstrado.

Paulo Restiffe Neto e Paulo Sérgio Restiffe, ao comentarem sobre a alienação fiduciária de bens móveis, esclarecem que embora tenha sido agora derrogado o art. 66 da Lei de Mercado de Capitais, que previa o registro do contrato no âmbito mercadológico ou financeiro para valer ou surtir efeitos em relação a terceiros, não se alterou esse efeito não constitutivo, que tem raízes no princípio da eficácia limitada erga omnes da publicidade documental do Registro de Títulos e Documentos, estabelecido na Lei de Registros Públicos em vigor (art. 129, $\S 5^{\circ}$ ). Continuam dizendo que vale o contrato entre as partes, independentemente do registro público, regra universal do direito das obrigações, que só poderia ser excepcionada por extraordinária previsão legal em razão da natureza do vínculo contratual - o que não é o caso do negócio jurídico de assunção de dívida garantida por pacto adjeto de alienação fiduciária de bem móvel. É que pela eficácia erga omnes do registro público (art. 129 da Lei de Registros Públicos), a publicidade adequada do ato produz efeito de oponibilidade em relação a terceiros, e não eficácia constitutiva entre os próprios contratantes, preexistentes no título ao ato registrário deste, que nada acrescenta em relação às partes, salvo a idoneidade como meio de prova eficiente e a vedação de novo ato de alienação fiduciária válida. (grifo nosso $)^{267}$

No mesmo sentido, Jean Fernandes assevera que a supressão da previsão de registro dos contratos de alienação e cessão fiduciária no sistema mercadológico e financeiro para produzir efeitos em relação a terceiros, antes previsto no revogado $\S 1^{\circ}$ do artigo 66 da Lei de Mercado de Capitais, não conduz à conclusão de que tais pactos prescindem da antiga exigência, que continua subsistindo por força do artigo $129, \S 5^{\circ}$ da Lei de Registros Públicos. (grifo nosso) $)^{268}$

\footnotetext{
${ }^{267}$ Alienação Fiduciária e o Fim da Prisão Civil, $1^{\text {a }}$ ed., p. 64 e 66.

${ }^{268}$ Cessão Fiduciária de Títulos de Crédito: a Posição do Credor Fiduciário na Recuperção Judicial da Empresa, p. 167.
} 
Melhim Chalhub defende que a cessão fiduciária tem caráter de direito real, que tem como objeto o direito creditório, somente tendo eficácia erga omnes depois de averbado o contrato no Registro de Imóveis competente (art. 17, §1 ${ }^{\circ}$ ), quando se tratar de crédito imobiliário, ou no Registro de Títulos e Documentos do domicílio do devedor, quando se tratar de cessão fiduciária sobre direitos ou títulos de crédito em geral, contratada no âmbito do mercado financeiro e de capitais. ${ }^{269}$

Por outro lado, Francisco Eduardo Loureiro ensina que o parágrafo $1^{\circ}$ do artigo 1.361 do CC explicita o preceito que a propriedade fiduciária se constitui com o registro, não havendo mais sentido em discutir se o registro tem efeito constitutivo ou publicitário e conclui pela inexistência de propriedade fiduciária sem o prévio e correto registro. ${ }^{270}$

Cesar Amendolara também é da opinião de que o registro do contrato é requisito de constituição da cessão fiduciária, em razão do disposto no parágrafo $1^{\circ}$ do artigo 1.361 do CC, que seria aplicável à cessão fiduciária. ${ }^{271}$

Christoph Fabian, ao comentar sobre o registro da alienação fiduciária prevista no artigo 66-B da Lei de Mercado de Capitais, também defende a aplicação das regras do artigo 1.361 do $\mathrm{CC} .^{272}$

A jurisprudência também tem caminhado nessa direção, ou seja, admitindo que a propriedade e/ou titularidade fiduciária prevista na Lei de Mercado de Capitais somente se constituem a partir do registro do contrato no Registro de Títulos e Documentos. Vejamos, nesse sentido, as ementas dos acórdãos proferidos pelos Desembargadores do Tribunal de Justiça do Estado de São Paulo:

"Agravo de Instrumento - Recuperação Judicial - Impugnação de crédito. Não tendo sido registrada a alienação fiduciária em garantia antes de distribuído o pedido de recuperação judicial, não pode ser arguida em detrimento dos demais credores e da recuperanda. Agravo desprovido." (TJSP, Agravo de Instrumento $n^{o}$ 633.332-4-0/00, julgado em 30.06.2009, relator Des. Lino Machado)

\footnotetext{
${ }^{269}$ Negócio Fiduciário, $4^{\mathrm{a}}$ ed., p. 356.

${ }^{270}$ In: Cezar Peluso (Coord.). Código Civil Comentado: doutrina e jurisprudência p. 1.242.

${ }^{271}$ Alienação Fiduciária Como Instrumento de Fomento à Concessão de Crédito. In: Ivo Waisberg (Coord.) e Marcos Rolim Fernandes Fontes (Coord.), Contratos Bancários, p. 189.

${ }^{272}$ Fidúcia: negócios fiduciários e relações externas, p. 84.
} 
"Agravo - Recuperação judicial - Depósito em conta judicial. Não tendo sido comprovado o registro do contrato, conforme ao que determina o art. 1361 do Código Civil, razoável a determinação da transferência para contas judiciais dos valores retidos a título de garantia. Agravo improvido." (TJSP, Agravo de Instrumento $n^{\circ}$ 527.909-4/6, julgado em 26.03.2008, Relator Des. Lino Machado.)

Transcrevemos abaixo parte do voto vencedor do Desembargador Romeu Ricupero no referido Agravo de Instrumento ${ }^{\circ}$ 527.909-4/6:

“(...) O segundo argumento da minuta e, na verdade, o de maior peso, é o de que o proprietário fiduciário não está sujeito à recuperação judicial, como expressamente decorre do artigo 49, $\S 3^{\circ}$, da Lei $n .^{\circ} 11.101 / 05$. Ora, embora as partes tenham querido celebrar cessão fiduciária de direitos, é certo que os contratos não foram registrados no Cartório de Títulos e Documentos, como acentuou o eminente Relator ao negar efeito suspensivo ao recurso, tema que sequer foi abordado pelo agravante no memorial agora ofertado. A recuperanda, por sua vez, em sua bem elaborada contraminuta e também no memorial apresentado por ocasião do julgamento, enfatizou, com citação de doutrina autorizada (GUILHERME GUIMARÃES FELICIANO, "Tratado de Alienação Fiduciária em Garantia", São Paulo, Editora LTr, 1999, pp. 362-363; MELHIM NEMEM CHALHUB, "Negócio Fiduciário", $2^{a}$ edição, Rio de Janeiro - São Paulo, Renovar, 2000, pp. 169-170; ORLANDO GOMES, "Alienação Fiduciária em Garantia", 4a edição, São Paulo, RT/1975, p. 61; PAULO RESTIFFE NETO, "Garantia Fiduciária", $2^{a}$ edição, São Paulo, RT, 1976, p. 130; JOÃO ROBERTO PARIZATTO, "Alienação Fiduciária", Edipa Editora e Distribuidora de Livros, 1998, p. 16; CÉSAR FIÚZA, "Alienação Fiduciária em Garantia de acordo com a Lei n. ${ }^{\circ}$ 9.514/97", $1^{a}$ edição, Rio de Janeiro, AIDE, 2000, p. 49), que a propriedade fiduciária só se considera constituída mediante o registro do contrato de alienação fiduciária. O atual Código Civil, no caput do art. 1.361, considera fiduciária a propriedade resolúvel de coisa móvel infungível que o devedor, com o escopo de garantia, transfere ao credor. É evidente, como anota FRANCISCO EDUARDO LOUREIRO, que existe profusa legislação especial tratando da matéria, mas aqui importa considerar o disposto no $\S 1^{o}$ do referido dispositivo legal, ou seja, "constitui-se a propriedade fiduciária com o registro do contrato, celebrado por instrumento público ou particular, que lhe serve de título, no Registro de Títulos e Documentos do domicílio do devedor, ou, em se tratando de veículos, na repartição competente para o licenciamento, fazendo-se a anotação no certificado de registro". O mencionado doutrinador ensina que "não há mais sentido em discutir se o registro tem efeito constitutivo ou publicitário" e conclui pela "inexistência de propriedade fiduciária sem o prévio e correto registro" (cf. "Código Civil Comentado", coordenador Ministro Cezar Peluso, $1^{a}$ edição, São Paulo, Manole, $p$. 1.242). No caso, os contratos não foram registrados $e$ inexiste a propriedade fiduciária, não se abrindo ensejo à aplicação do disposto no artigo 49, $\S 3^{\circ}$, da Lei $n .^{\circ}$ 11.101/05. Destarte, pelo meu voto, nego provimento ao recurso.” (grifo nosso) 
Embora a cessão ordinária de crédito seja válida pelo simples acordo entre as partes, em se tratando de cessão fiduciária de crédito há efetiva transferência da titularidade do crédito ao cessionário-fiduciário.

Tendo em vista que o artigo 1.368-A do CC permite a aplicação dos dispositivos do Código, naquilo que não for incompatível com a legislação especial, às demais espécies de propriedade fiduciária ou de titularidade fiduciária previstas na legislação especial e, considerando que o disposto no parágrafo $1^{\circ}$ do artigo 1.361 do CC não é incompatível com a Lei de Mercado de Capitais, que nada dispõe acerca do registro da cessão fiduciária, $\underline{\text { somos da opinião de que há necessidade do registro do contrato de cessão fiduciária no }}$ $\underline{\text { Registro de Títulos e Documentos para dar efeito constitutivo da titularidade fiduciária }}$ criada em favor do cessionário-fiduciário.

\subsection{Da Mora e do Inadimplemento do Devedor-Fiduciante}

O parágrafo $3^{\circ}$ do artigo 66-B da Lei de Mercado de Capitais, que disciplina a cessão fiduciária de crédito, não faz qualquer alusão sobre a necessidade de se constituir o devedor-fiduciante em mora na hipótese de não pagamento de parcela da dívida em sua respectiva data de vencimento, assim como nada menciona acerca da possibilidade de o devedor purgar a mora.

Apesar da omissão da Lei de Mercado de Capitais, entendemos que as regras sobre a mora contidas no Código Civil são plenamente aplicáveis à hipótese de inadimplemento pelo devedor-fiduciante de sua obrigação de pagar a dívida no prazo. O artigo 397 do CC prevê que o inadimplemento de obrigação, positiva e líquida, no seu termo, constitui de pleno direito em mora o devedor. Portanto, não há necessidade de envio de notificação ao devedor-fiduciante para constituí-lo em mora. Nada impede, todavia, que o devedor purgue a mora, oferecendo a prestação inadimplida, mais a importância dos prejuízos decorrentes do atraso, conforme autoriza o inciso I do artigo 401 do CC. 
Se o devedor-fiduciante não pagar a dívida no prazo e não purgar a mora, tal inadimplemento constituirá causa de vencimento antecipado da dívida, nos termos do artigo 1.425, inciso III do CC, que se aplica subsidiariamente à cessão fiduciária de crédito por expressa disposição do parágrafo $4^{\circ}$ do art. 66-B da Lei de Mercado de Capitais.

Em razão do vencimento antecipado da dívida e da rescisão do contrato principal, poderá o credor-fiduciário utilizar os créditos recebidos e depositados na conta-vinculada do devedor-fiduciante para amortizar os valores inadimplidos pelo devedor-fiduciante e, se houver saldo credor remanescente, o credor-fiduciário deverá restituir o respectivo valor ao devedor-fiduciante. ${ }^{273}$

Todavia, se as importâncias recebidas dos créditos cedidos fiduciariamente não bastarem para o pagamento integral da dívida e seus encargos, bem como das despesas de cobrança e de administração daqueles créditos, o devedor-fiduciante continuará obrigado a pagar o saldo devedor remanescente, nas condições convencionadas no contrato com o credor-fiduciário.

Nesta hipótese, se o credor-fiduciário ainda tiver em seu poder créditos cedidos fiduciariamente ainda não vencidos, entendemos que o credor-fiduciário poderá utilizar todos os meios possíveis para tentar reduzir o seu prejuízo, seja mediante a cessão com deságio dos referidos créditos a terceiros, seja pela cobrança do referido título quando de sua data de vencimento. De qualquer forma, o devedor-fiduciante permanece responsável pelos encargos (juros, multa e correção monetária) sobre o valor inadimplido desde a data do inadimplemento até a data em que houver o efetivo pagamento da dívida pelo devedorfiduciante ou até a data em que o credor-fiduciário conseguir recuperar a totalidade dos créditos cedidos em garantia.

\footnotetext{
${ }^{273}$ Pestana de Vasconcelos (A cessão de créditos em garantia e a insolvência: em particular da posição do cessionário na insolvência do cedente, p. 599, nota 1155) ressalta que a função desempenhada pelo direito transmitido, neste caso o crédito, é assegurar a obrigação garantida e só subsidiariamente, em segunda linha, servir de meio solutório - se o devedor não cumprir. Na generalidade dos casos, o cedente/fiduciário, com vista a readquirir o crédito, cumprirá. Só se ele não o fizer, o cessionário/fiduciário poderá recorrer à sua liquidação para dessa forma obter o montante em dívida que não foi pago. Somente nesse momento a cessão adquire um caráter solutório.
} 
Como bem salienta Pontes de Miranda, na cessão fiduciária para garantia, o cessionário pode cobrar o crédito quando já exigível, no seu interesse (pois que lhe foi garantido com a cessão) e no do cedente, que se libera e tem direito a receber o excesso sobre o seu débito. ${ }^{274}$

Navarro Martorell observa que geralmente o vencimento da obrigação causal, se o cedente não cumpriu suas obrigações para com o cessionário, é o momento que determina desde quando este último tem a faculdade de cobrar o crédito cedido e se fazer pago com este crédito. ${ }^{275}$

A possibilidade de a instituição financeira utilizar os créditos recebidos em garantia para amortizar a dívida contraída pelo devedor está em perfeita consonância com o disposto no artigo 66-B da Lei de Mercado de Capitais, com a redação dada pela Lei $\mathrm{n}^{\circ}$ 10.931/2004, que não veda o pacto comissório, diferentemente do que previa o revogado parágrafo $6^{\circ}$ do artigo 66 da Lei de Mercado de Capitais que tornava nula a cláusula que autorizasse o proprietário fiduciário a ficar com a coisa alienada em garantia, se a dívida não fosse paga no seu vencimento.

Mais ainda, o artigo 19 da LSFI determina que ao credor fiduciário compete receber diretamente dos devedores do cedente os créditos cedidos fiduciariamente. As importâncias recebidas, depois de deduzidas as despesas de cobrança e de administração, serão creditadas ao devedor-fiduciante, na operação objeto da cessão fiduciária, até final liquidação da dívida e encargos, responsabilizando-se o credor-fiduciário perante o devedor-fiduciante, como depositário, pelo que receber além do que este lhe devia.

Por outro lado, se as importâncias recebidas não bastarem para o pagamento integral da dívida e seus encargos, bem como das despesas de cobrança e administração daqueles créditos, o devedor-fiduciante continuará obrigado a resgatar o saldo remanescente nas condições convencionadas entre as partes (art. 19, parágrafo segundo da LSFI).

\footnotetext{
${ }^{274}$ Tratado de Direito Privado, Parte Especial, Tomo XXIII, p. 285.

${ }^{275}$ La Propriedad Fiduciaria, p. 317.
} 
Resta claro, portanto, que o artigo 66-B da Lei de Mercado de Capitais, combinado com o artigo 19 da LSFI, permite que a instituição financeira utilize-se dos créditos recebidos em cessão fiduciária para abater a dívida do cedente em caso de inadimplemento deste último, pois a cessão fiduciária de créditos tem como uma de suas principais características este mecanismo de satisfação do credor, sem a necessidade de que ele se socorra da via judicial. ${ }^{276}$

É comum na prática bancária que os contratos de cessão fiduciária de crédito permitam que a instituição financeira possa utilizar-se dos créditos cedidos pelo devedorcedente, como garantia de uma determinada operação financeira, para abater toda e qualquer dívida que o devedor-cedente tenha contraído com a referida instituição financeira. Assim, caso o devedor não cumpra com qualquer obrigação pecuniária perante a instituição financeira, esta última poderia utilizar os créditos cedidos fiduciariamente para uma determinada transação para abater a totalidade ou parte da dívida inadimplida oriunda de uma outra transação.

No entanto, somos da opinião que tal prática não encontra respaldo jurídico, pois a cessão fiduciária de créditos em garantia tem por finalidade precípua garantir uma determinada dívida contraída pelo devedor perante a instituição financeira e não toda e qualquer dívida do referido devedor. O próprio artigo 18 da LSFI estipula claramente que o contrato de cessão fiduciária de créditos em garantia deva fixar o valor total da dívida ou sua estimativa.

Desta forma, a menos que a instituição financeira inclua no contrato de cessão fiduciária de créditos em garantia o total e/ou estimativa de todas as dívidas que o devedor possua, naquele momento, com a instituição financeira, não se pode admitir que o inadimplemento de uma determinada obrigação possa ser considerado causa de vencimento antecipado do contrato de cessão fiduciária de créditos em garantia de outra obrigação.

Por conseqüência, a instituição financeira não poderá utilizar-se dos créditos cedidos fiduciariamente como garantia de uma determinada obrigação para amortizar parte ou a totalidade de outras dívidas inadimplidas pelo devedor perante a mesma instituição

\footnotetext{
${ }^{276}$ Sobre o mecanismo de auto-satisfação do credor ver Pestana de Vasconcelos, A cessão de créditos em garantia e a insolvência: em particular da posição do cessionário na insolvência do cedente, pp. 609 e 915.
} 
financeira, que não tenham sido garantidas por aquele contrato de cessão fiduciária de créditos.

\subsection{Situação Patrimonial da Cessão Fiduciária de Créditos e de Títulos de Crédito}

Da análise dos institutos do trust e do fideicomisso latino-americano verifica-se que tais institutos adotam a teoria do patrimônio de afetação dos bens que integram o trust ou o fideicomisso como forma de proteger os referidos bens da insolvência do cessionário.

Desta forma, tanto os bens objeto do trust quanto os bens fideicomitidos formam um patrimônio separado, que é afetado ao cumprimento de uma obrigação específica. Significa dizer que os bens integrantes do trust, bem assim os bens fideicomitidos não estão sujeitos nem à falência do devedor fiduciante nem à do credor fiduciário. Com esta formulação, protege-se o patrimônio afetado e concede-se uma maior segurança jurídica às partes.

Por seu turno, a cessão fiduciária de crédito e/ou de títulos de crédito promove a transferência do crédito e/ou título de crédito ao credor-cessionário. Embora esta transferência seja plena e efetiva, o credor somente poderá utilizar o valor do crédito cedido para abater as parcelas inadimplidas da dívida do devedor-fiduciante com o credorcessionário. Significa dizer que a garantia fiduciária composta pelos valores dos créditos e/ou títulos de crédito cedidos ao credor-fiduciário está diretamente relacionada à obrigação principal assumida entre as partes.

Resta saber se tal como o trust e o fideicomisso, os créditos cedidos ao credorfiduciário constituiriam ou não um patrimônio separado do patrimônio do credor-fiduciário e se eles seriam afetados unicamente ao cumprimento da obrigação garantida. Para se chegar a esta resposta será necessário estudar o conceito de patrimônio, sua distinção entre patrimônio geral e especial (ou separado), bem como as principais características do patrimônio separado. 


\subsubsection{Teorias sobre o Patrimônio}

Antes de adentrarmos ao conceito de patrimônio, importante mencionar a distinção feita pela doutrina e também adotada pelo nosso Código Civil entre universalidade de fato e de direito.

$\mathrm{O}$ artigo 90 do $\mathrm{CC}$ define universalidade de fato como sendo a pluralidade de bens singulares que, pertinentes à mesma pessoa, tenham destinação unitária, sendo que os bens que formam essa universalidade podem ser objeto de relações jurídicas próprias. $\mathrm{O}$ artigo 91 do CC define universalidade de direito como o complexo de relações jurídicas, de uma pessoa, dotadas de valor econômico.

Na mesma linha seguida pelo Código Civil, Orlando Gomes define a universalidade de fato como o conjunto de coisas singulares, simples ou compostas, agrupadas pela vontade da pessoa, tendo destinação comum, como um rebanho, ou uma biblioteca. A unidade baseia-se na realidade natural. Já a universalidade de direito é um complexo de direitos e obrigações a que a ordem jurídica atribui caráter unitário, como o dote ou a herança. A unidade é resultante de lei. ${ }^{277}$

Segundo Clóvis Beviláqua patrimônio é o complexo de relações jurídicas de uma pessoa, que tiverem valor econômico. Compreendem-se no patrimônio tanto os elementos ativos como os passivos, isto é, os direitos de ordem privada economicamente apreciáveis e as dívidas. ${ }^{278}$ Para Fernando Noronha essa concepção de patrimônio corresponderia ao patrimônio global. Numa acepção mais restrita, fala-se em patrimônio bruto quando se pretende referir apenas os direitos com valor econômico, excluindo as obrigações e, finalmente, fala-se em patrimônio líquido para significar a diferença existente entre o ativo e o passivo. O mesmo autor conclui que as expressões "patrimônio" e "universalidade de direitos" seriam sinônimas e que uma pessoa poderá ter diversos patrimônios. ${ }^{279}$

\footnotetext{
${ }^{277}$ Introdução do direito civil. $11^{\mathrm{a}}$ ed., p. 227.

${ }^{278}$ Theoria geral do direito civil, pp. 210 e 211.

${ }^{279}$ Patrimônios especiais: sem titular, autônomos e coletivos. In: Revista dos Tribunais, ano 87, jan 1998, v. 747, pp. 15 e 16.
} 
Na definição de Oscar Barreto Filho, a significação econômica do patrimônio faz com que nele se compreendam tanto os elementos ativos (os bens econômicos) quanto os passivos (as dívidas, que também constituem bens do ponto de vista dos credores). Patrimônio líquido é o que resta depois de solvido o passivo, e constitui a expressão econômica atual do patrimônio. Barreto Filho observa que alguns autores afirmam que os débitos não seriam elementos constitutivos do patrimônio, mas sim ônus ou encargo. Todavia, tendo em vista que o patrimônio do devedor é a garantia comum dos credores, o titular do patrimônio não poderia admitir como ativo de que possa livremente dispor, senão aquela parte que exceder ao passivo. ${ }^{280}$

A doutrina formulou diversas teorias acerca do patrimônio ${ }^{281}$, sendo as duas principais a teoria clássica, de caráter subjetivo e personalista, cuja elaboração se deveu principalmente a Aubry e Rau; e a teoria moderna, de orientação objetiva e realista, à qual se filiam Duguit, Brinz, Bekker e vários escritores germânicos. ${ }^{282}$

Para Aubry e Rau, o patrimônio é o conjunto dos bens de uma pessoa, considerado como universalidade de direito. A idéia de patrimônio decorre da idéia de personalidade, pois, seja qual for a variedade de coisas (objetos) sobre as quais o homem tenha direitos a exercer, este objetos, formando a matéria dos direitos de uma pessoa determinada, se encontram sujeitos ao livre-arbítrio de uma única e mesma vontade. Por ser o patrimônio a emanação da personalidade, é a expressão do poder jurídico a que toda pessoa, como tal, se acha investida. Daí resulta que: 1) somente as pessoas, naturais ou jurídicas, podem ter patrimônio; 2) toda pessoa tem, necessariamente, um patrimônio, ainda que atualmente não possua nenhum bem; 3) cada pessoa só pode ter um patrimônio. O patrimônio, em princípio, é uno e indivisível como a própria personalidade que, em razão de sua natureza incorpórea, não é divisível em partes materiais ou quantitativas, nem tampouco, em universalidades jurídicas distintas umas das outras, sendo entretanto, suscetível de divisão em quotas ou partes ideais. ${ }^{283}$

\footnotetext{
${ }^{280}$ Teoria do estabelecimento comercial: fundo de comércio ou fazenda mercantil. $2^{\mathrm{a}}$ ed., p. 48.

${ }^{281}$ Paulo A. V. Cunha (Do património: Estudo de direito privado. Lisboa: Minerva, 1934) defendeu a existência de seis vertentes da teoria sobre o patrimônio, observando que das teorias mais exclusivamente personalistas, até as teorias mais rasgadamente objetivistas, pode caminhar-se através de uma gama de modalidades doutrinais, cujas diferenças são quase imperceptíveis.

${ }^{282}$ Ibid., p. 49.

${ }^{283}$ Cours de droit civil français d'après la méthode de Zcharie, tomo IX, §§ 573 e 574, pp. 333 e ss.
} 
Os defensores da teoria clássica vinculam a noção de patrimônio e personalidade, que confundir-se-iam. O patrimônio seria a emanação da personalidade e expressão desta no campo econômico. Desse postulado, a teoria clássica extraía três corolários: só pessoas físicas ou jurídicas podem ter patrimônio, toda pessoa tem necessariamente um, a mesma pessoa só pode ter um único patrimônio. ${ }^{284}$

Da definição trazida pela teoria clássica é possível inferir-se que o patrimônio seria uno e indivisível e que a mesma pessoa, física ou jurídica, poderia deter apenas um único patrimônio. Com base nesta doutrina, ficaria difícil conceber-se a idéia de patrimônio sem titular, ou ainda, de patrimônios especiais, segregados do patrimônio geral da mesma pessoa física ou jurídica.

Por outro lado, a teoria moderna, de caráter objetivista, defende que existe o patrimônio quando há a afetação legal de uma massa de bens a uma finalidade, respondendo por dívidas a ela relacionadas. Esta teoria admite a possibilidade de criação de um ou vários outros patrimônios, denominados patrimônios especiais, com maior ou menor independência em relação àquele patrimônio, denominado patrimônio geral ou comum. ${ }^{285}$ Desta forma, a teoria moderna procura justificar a coesão dos elementos que compõem o patrimônio em razão da sua destinação.

\subsubsection{Patrimônio Geral e Especial (ou Separado)}

Como já mencionado no item 3.9.1 acima, o patrimônio geral é o complexo de relações jurídicas de uma pessoa, compreendendo-se tanto os elementos ativos como os passivos. O patrimônio geral do devedor responde pelo cumprimento de suas obrigações, salvo as restrições estabelecidas na lei, nos termos do artigo 591 do CPC. Significa, dizer, portanto, que a separação patrimonial deverá ser prevista em lei, por ser uma exceção ao princípio geral de que a totalidade do patrimônio responde pelas dívidas do devedor. Este patrimônio especial é também denominado pela doutrina como patrimônio separado ou autônomo. $^{286}$

${ }^{284}$ Fernando Noronha, Patrimônios especiais: sem titular, autônomos e coletivos. In: Revista dos Tribunais, v. 747, ano 87, jan 1998, p. 17.

${ }^{285}$ Ibid., pp. 18 e 19.

${ }^{286}$ Conforme ensina Orlando Gomes (Introdução ao Direito Civil, $11^{\mathrm{a}}$ ed., p. 203 e nota 6) a idéia de afetação explica a possibilidade da existência de patrimônios especiais, consistente numa restrição pela qual 
Pontes de Miranda observa que todo patrimônio especial tem um fim que lhe traça esfera própria e esse fim pode ser fixado ou por manifestação de vontade ou por lei, é e dessa especialização que nascem direitos e obrigações inerentes a esse patrimônio. ${ }^{287}$

Ao discorrer sobre o patrimônio separado, Caio Mario sustenta que ele tem sua fonte essencial na lei, pois não é ele possível senão quando imposto ou autorizado pelo direito positivo, aparecendo toda vez que certa massa de bens é sujeita a uma restrição em benefício de um fim específico. ${ }^{288}$

No mesmo sentido, Melhim Chalhub defende que a constituição de massas patrimoniais separadas só é admitida nas hipóteses explicitamente autorizadas por lei e com as limitações que a lei prescrever, pois a separação de certos bens do patrimônio de uma pessoa pode, evidentemente, implicar redução da garantia geral dos credores representada pelo patrimônio geral. ${ }^{289}$

Christoph Fabian também defende que embora as partes possam dar a um bem uma determinada finalidade, esta estipulação individual não poderá ter efeitos contra terceiros, mas somente entre os dois contratantes. A liberdade de se constituir arbitrariamente um patrimônio separado prejudicaria essencialmente os credores (como terceiros) no seu interesse legítimo em obter uma garantia pelos bens do devedor. Finalmente, um devedor poderia eximir parte de seu patrimônio da execução por credores. ${ }^{290}$

Por outro lado, há quem defenda que o patrimônio separado poderia ser constituído por vontade das partes. Esta é a opinião defendida por Orlando Gomes, que sustenta nada justificar a proibição de se constituir um patrimônio separado. Dizer-se que ninguém pode, por ato de sua vontade, limitar a responsabilidade com eficácia absoluta, é desconhecer que essa possibilidade está admitida em nosso Direito pelo reconhecimento de outros processos técnicos. $^{291}$

determinados bens se dispõem para servir a fim desejado, limitando-se, por este modo, a ação dos credores. Orlando Gomes esclarece que a idéia de afetação foi enunciada pela primeira vez por Brinz para explicar a natureza da pessoa jurídica (Zweckvermogenstheorie).

${ }^{287}$ Tratado de Direito Privado, Tomo V, p. 379.

${ }^{288}$ Instituições de Direito Civil, v. I, $21^{\text {a }}$ ed., p. 399.

${ }^{289}$ Negócio Fiduciário, $4{ }^{\mathrm{a}}$ ed., p. 72.

${ }^{290}$ Fidúcia: negócios fiduciários e relações externas, p. 226.

${ }^{291}$ A Reforma do Código Civil, pp. 201 e 202. 
No mesmo sentido, Francisco Eduardo Loureiro diz que a propriedade fiduciária constitui patrimônio de afetação, porque despida de dois dos poderes federados do domínio - jus utendi e fruendi; que se encontram nas mãos do devedor fiduciante. O credor fiduciário tem apenas o jus abutendi e, mesmo assim, sujeito à condição resolutiva, destinado, afetado a somente servir de garantia ao cumprimento de uma obrigação. ${ }^{292}$

Como bem observa Larenz, a função do patrimônio separado é a de satisfazer primordialmente ou de modo exclusivo os credores ou um determinado grupo de credores. O referido autor observa que a administração de herança e o concurso sucessório têm por objeto especificamente a satisfação dos credores hereditários. Há casos em que pretende-se separação do patrimônio para a formação de um patrimônio especial ou sua conservação em favor de um sucessor. Por fim, a separação patrimonial ocorreria nos regimes matrimoniais em que os frutos de certos bens particulares passam a ser comuns enquanto os de outros bens, também não comunicáveis, permanecem sob a titularidade de apenas um dos cônjuges. ${ }^{293}$

Fernando Noronha divide os patrimônios especiais em absoluta e relativamente independentes. Os patrimônios especiais absolutamente independentes são aqueles rigorosamente separados do geral, por isso com duas características: a) irresponsabilidade deles por qualquer dívida que não se relacione com a finalidade a que cada um está afetado; b) irresponsabilidade de qualquer outro patrimônio pelas dívidas incluídas no passivo de cada um daqueles. Já os patrimônios especiais relativamente independentes do geral podem ser divididos em dois grupos: os que só respondem por dívidas relacionadas com a sua função específica, ou seja, com a finalidade com vista à qual se fez a sua afetação, mas onde também já há outros patrimônios (o geral, ou até outros especiais) respondendo por essas mesmas dívidas; e os que só respondem em princípio pelas próprias dívidas, mas, podendo, subsidiariamente, responder por encargos de outros patrimônios. ${ }^{294}$

\footnotetext{
${ }^{292}$ In: PELUSO, Cezar. (Coord.). Código Civil Comentado: doutrina e jurisprudência, $3^{\mathrm{a}}$ ed., p. 1.372.

${ }^{293}$ Derecho Civil: parte II, traduzido do alemão para o espanhol por Miguel Izquierdo y Macías-Picavea, pp. 414 e 415.

${ }^{294}$ Patrimônios especiais: sem titular, autônomos e coletivos. In: Revista dos Tribunais, v. 747, ano 87, jan 1998, , pp. 23 e 24.
} 
Von Tuhr atribui uma série de características ao patrimônio especial. Observa o referido autor que a situação peculiar do patrimônio especial decorre dos fins especiais que a determina. Já o patrimônio geral serve a fins gerais. Os patrimônios especiais estão afetados ao fim de sua liquidação: o titular ou um representante especial devem empregá-lo à satisfação de uma determinada classe de credores. O patrimônio separado pode ser administrado por outra pessoa que não o seu titular. Os elementos que compõem o patrimônio especial são fixados por lei ou por negócio jurídico, todos os demais integram o patrimônio geral. A lei não estabelece de maneira fixa os limites entre patrimônio especial e geral. Em certos casos permite-se aos interessados transferir os bens que integram o patrimônio especial para o geral. O patrimônio especial também pode ter um passivo ao lado do ativo, não sendo certo falar-se em "obrigações do patrimônio especial”, pois o obrigado seria o titular do patrimônio, ou aquele que exerce a sua administração, sendo certo que o patrimônio especial responderá pelas suas obrigações em caso de inadimplemento. Por fim, adverte o referido autor a possibilidade de haver relações jurídicas entre o patrimônio geral e o especial. ${ }^{295}$

\subsubsection{Regime Patrimonial dos Créditos Cedidos Fiduciariamente: patrimônio geral ou especial?}

Tendo em vista que a Lei de Mercado de Capitais nada dispõe acerca do regime patrimonial dos créditos cedidos fiduciariamente, resta saber se tais créditos poderiam constituir um patrimônio especial, separado do patrimônio geral do credor fiduciário, afetado unicamente a assegurar o cumprimento da obrigação principal assumida entre devedor-fiduciante e credor-fiduciário.

Em razão de a cessão fiduciária ser uma espécie de negócio jurídico, cuja origem remonta à fiducia cum creditore do direito romano, pela qual o credor passa a deter a titularidade plena dos créditos a ele cedidos para garantir a dívida contraída pelo devedor, um dos riscos do fiduciante em relação ao fiduciário é justamente o de sujeição de tais créditos aos efeitos da falência do credor.

\footnotetext{
${ }^{295}$ Derecho Civil: Teoría General del Derecho Civil Alemán, v.1, traduzido do alemão para o espanhol por Tito Ravá, pp. 334 e ss.
} 
Otto de Souza Lima observa que aqueles que seguem a teoria romanística, consideram o fiduciário titular absoluto dos direitos a ele transmitidos. Sustentam, consequentemente, em sua maior parte, que a falência compreende todos os bens do fiduciário, inclusive, pois, os que são objeto da fidúcia. Coerentemente, dão ao fiduciante, na falência do fiduciário, apenas, os direitos obrigacionais decorrentes do pactum fiduciae, que constituem simples créditos quirografários, sem qualquer eficácia real. ${ }^{296}$

No mesmo sentido, Francesco Ferrara adverte que uma última conseqüência que deriva da titularidade do fiduciário, é que em caso de quebra, a coisa transmitida fiduciariamente é abrangida na massa do concurso sem que ao fiduciante caiba qualquer direito de separação. ${ }^{297}$

Christoph Fabian sustenta que a reflexão sobre as soluções tomadas principalmente nos países vinculados na tradição do direito romano conduz a defender a idéia de que uma solução satisfatória só pode ser alcançada por lei. Conclui o referido autor sobre a questão do negócio fiduciário geral ou inominado na falência que, atualmente, o fiduciário responde também com o patrimônio fiduciário. A perspectiva segue a situação real do bem: o fiduciário obtém a propriedade e também responde com ela, revelando a discrepância entre a relação interna e o poder externo do fiduciário. ${ }^{298}$

Alfredo Buzaid, ao comentar sobre alienação fiduciária, sustenta que o bem adquirido mediante alienação fiduciária em garantia pertence ao fiduciário, integrando a massa de seu patrimônio. ${ }^{299}$

No direito brasileiro a constituição de um patrimônio separado depende de lei que a autorize, pois é medida excepcional à regra de que todos os bens do patrimônio respondem pelas dívidas do devedor.

\footnotetext{
${ }^{296}$ Negócio Fiduciário, p. 207.

${ }^{297}$ A Simulação dos Negócios Jurídicos, trad. A. Bossa, p. 88.

${ }^{298}$ Fidúcia: negócios fiduciários e relações externas, p. 239.

${ }^{299}$ Ensaio sobre a alienação fiduciária em garantia. In: Revista dos Tribunais, v. 401, março de 1969, p. 28.
} 
Como já demonstrado no item anterior, a maioria da doutrina segue esta linha de pensamento, não admitindo que as próprias partes segreguem um bem para cumprir uma finalidade específica.

Desta forma, tendo em vista que a Lei de Mercado de Capitais não prevê a criação de um patrimônio separado para os créditos cedidos fiduciariamente, adotamos o entendimento de que tais créditos passam a integrar o patrimônio do credor-fiduciário e estarão sujeitos aos efeitos da falência do fiduciário. 


\section{CAPÍTULO IV - TRATAMENTO DA CESSÃO FIDUCIÁRIA NAS HIPÓTESES DE RECUPERAÇÃO JUDICIAL E FALÊNCIA DO DEVEDOR-FIDUCIANTE}

Neste capítulo será abordado o tratamento da cessão fiduciária de créditos e/ou títulos de crédito nas hipóteses de recuperação judicial e falência do devedor-fiduciante. Iniciaremos com o estudo do processo legislativo da LRE no tocante ao artigo 49, parágrafo $3^{\circ}$, que excluiu determinados créditos dos efeitos da recuperação judicial do devedor. Passaremos, então, a uma análise interpretativa do artigo 49, parágrafo $3^{\circ}$ da LRE para verificar se a cessão fiduciária de créditos e/ou títulos de crédito poderia ser inserida no conceito de "propriedade fiduciária de bens móveis" contemplada no referido artigo. Depois, analisaremos a posição da doutrina e da jurisprudência sobre o tratamento da cessão fiduciária de crédito na recuperação judicial do devedor-fiduciante. Faremos uma análise crítica do impacto econômico da solução adotada pelo legislador tomando-se por base os princípios da preservação da empresa e da sua função social e, finalmente, abordaremos o tratamento da cessão fiduciária de créditos na falência do devedorfiduciante.

\subsection{Elaboração Legislativa do Atual Artigo 49, parágrafo $3^{\circ}$ da LRE}

\subsubsection{Tramitação na Câmara dos Deputados}

A atual LRE decorreu do Projeto de Lei no 4.376, de 1993 apresentado na Câmara dos Deputados por iniciativa do Poder Executivo. Na versão original do referido projeto de lei não havia qualquer menção sobre os credores titulares da posição de proprietários fiduciários de bens móveis ou imóveis.

Por meio da Emenda Substitutiva de $\mathrm{n}^{\circ}$ 102, apresentada pelo Deputado Joavir Arantes em 27.09.1999, foi proposta nova redação ao artigo 30 do substitutivo determinando que os credores titulares da posição de proprietários fiduciários estariam excluídos dos efeitos da recuperação judicial do devedor: 
“Art. 30. Estão sujeitos aos efeitos da recuperação judicial todos os credores anteriores ao pedido, inclusive a Fazenda Pública, seja qual for a natureza do seu crédito, observado, quanto a esta, o disposto no artigo 45 desta lei.

(...)

$\$ 4^{o}$ Tratando-se de credor titular da posição de proprietário fiduciário, de arrendador mercantil, ou de proprietário ou compromissário comprador de fração ideal de imóvel, com cláusula de irrevogabilidade ou irretratabilidade, prevalecerão, para todos os efeitos, os direitos de propriedade sobre a coisa alienada fiduciariamente ou objeto de arrendamento mercantil, ou venda ou promessa de venda de fração ideal de imóvel, qualificada pelas cláusulas de irrevogabilidade e irretratabilidade, observando-se neste último caso, no que for cabível, o art. 107 desta lei."

A referida Emenda Substitutiva de ${ }^{\circ} 102$ foi parcialmente acolhida pela comissão especial e na subemenda global às emendas de plenário ao substitutivo adotado pela comissão especial ao Projeto de Lei $\mathrm{n}^{\circ}$ 4.376/93 (conforme consta da página 518 do PEP-1 ao Projeto de Lei ${ }^{\circ}$ 4.376/93 de 25.03.1998), a redação do artigo 40 do referido Projeto ficou assim redigida:

“Art. 40. Estão sujeitos aos efeitos da recuperação judicial todos os credores anteriores ao pedido, inclusive a Fazenda Pública, seja qual for a natureza do seu crédito, observado, quanto a esta, o disposto no artigo 55 desta lei.

(...)

$\$ 4^{\circ}$ Tratando-se de credor titular da posição de proprietário fiduciário, de arrendador mercantil, ou de proprietário ou compromissário comprador de fração ideal de imóvel, com cláusula de irrevogabilidade ou irretratabilidade, prevalecerão, para todos os efeitos, os direitos de propriedade sobre a coisa alienada fiduciariamente ou objeto de arrendamento mercantil, ou venda ou promessa de venda de fração ideal de imóvel, qualificada pelas cláusulas de irrevogabilidade e irretratabilidade, observando-se, neste último caso, no que couberem, os arts. 117 e 119 desta lei."

Importante mencionar que a Emenda Substitutiva de $\mathrm{n}^{\circ} 102$ foi apresentada pelo Deputado Joavir Arantes em 27.09.1999 e, portanto, dois anos após a edição da LSFI que regulou o Sistema de Financiamento Imobiliário, instituindo a alienação fiduciária de coisa imóvel. O artigo 17, inciso II da LSFI permitia que as operações de financiamento imobiliário em geral pudessem ser garantidas por cessão fiduciária de direitos creditórios decorrentes de contratos de alienação de imóveis. 
Feitas essas considerações, da leitura do parágrafo $4^{\circ}$ do artigo 40 acima citado não nos parece que o legislador tinha a intenção de englobar no conceito de "proprietário fiduciário" os titulares de créditos cedidos fiduciariamente em garantia das operações de financiamento imobiliário previstas na LSFI, pois a redação da parte final do parágrafo $4^{\circ}$ do artigo 40 menciona que prevalecerão, para todos os efeitos, os direitos de propriedade sobre a coisa alienada fiduciariamente que, ao nosso ver, é bem corpóreo.

Em 11.07.2003, vários deputados liderados pelo Deputado Roberto Magalhães apresentaram a Emenda Substitutiva de $\mathrm{n}^{\circ} 137$, que alterou diversos dispositivos do PL $\mathrm{n}^{\circ}$ 4.376/1993. Nesta Emenda foram propostas algumas alterações que estão em negrito à redação do parágrafo $3^{\circ}$ do artigo 48 , conforme abaixo:

“Art. 48. Estão sujeitos aos efeitos da recuperação judicial os créditos anteriores ao pedido.

(...)

$\$ 3^{\circ}$ Tratando-se de credor titular da posição de proprietário fiduciário de bens móveis ou imóveis, de arrendador mercantil, ou de proprietário ou promitente vendedor de imóvel, cujos respectivos contratos contenham cláusula de irrevogabilidade ou irretratabilidade, inclusive em incorporações imobiliárias, ou de proprietário em contrato de venda com reserva de domínio, prevalecerão os direitos de propriedade sobre a coisa e as condições contratuais, observada a legislação respectiva, podendo ainda o plano de recuperação judicial prever outras condições de cumprimento do contrato, na forma do art. 51, I desta lei."

No parecer do relator designado pela mesa em substituição à comissão especial às emendas de plenário ao Projeto de Lei no 4.376/1993 (PPP-1, de 27.07.2003), o Deputado Osvaldo Biolchi informou que a Emenda Substitutiva de $n^{\circ} 137$ foi incorporada ao texto.

Todavia, na reformulação parcial do voto no parecer sobre as emendas de plenário ao Projeto de Lei n ${ }^{\circ}$ 4.376/1993 (PPR-1, de 30.07.2003), o Deputado Osvaldo Biolchi esclareceu que alguns artigos da subemenda substitutiva sofreram pequenas alterações em sua redação. Dentre esses artigos, houve modificação do artigo 48, parágrafo $3^{\circ}$ para excluir a parte final da redação proposta na Emenda Substitutiva $n^{\circ} 137$ que permitia que o plano de recuperação judicial previsse outras condições para cumprimento dos contratos de alienação fiduciária, arrendamento mercantil, promessa de compra e venda de imóvel, venda com reserva de domínio. 
Desta forma, na subemenda substitutiva às emendas de plenário ao substitutivo adotado pela comissão especial ao PL n ${ }^{\circ}$ 4.376/1993 o artigo 48 ficou assim redigido:

“Art. 48. Estão sujeitos aos efeitos da recuperação judicial os créditos anteriores ao pedido.

(...)

$\S 3^{\circ}$ Tratando-se de credor titular da posição de proprietário fiduciário de bens móveis ou imóveis, de arrendador mercantil, ou de proprietário ou promitente vendedor de imóvel, cujos respectivos contratos contenham cláusula de irrevogabilidade ou irretratabilidade, inclusive em incorporações imobiliárias, ou de proprietário em contrato de venda com reserva de domínio, prevalecerão os direitos de propriedade sobre a coisa e as condições contratuais, observada a legislação respectiva."

Em 15.10.2003 foi votada na Câmara dos Deputados a redação final do PL $\mathrm{n}^{\circ}$ 4.376/1993, que manteve a redação acima para o artigo 48, parágrafo $3^{\circ}$. O PL n ${ }^{\circ}$ 4.376/1993 foi encaminhado ao Senado Federal em 23.10.2003.

\subsubsection{Tramitação no Senado}

O PL no 4.376/1993 recebeu no Senado Federal o número PLC n 71 , de 2003. O referido projeto tramitou na Comissão de Assuntos Econômicos - CAE, sendo relator o Senador Ramez Tabet, e também na Comissão de Constituição, Justiça e Cidadania - CCJ, sendo relator o Senador Fernando Bezerra.

Dentre as diversas Emendas ao PLC n ${ }^{\circ}$ 71, de 2003, as Emendas 89, 107 e 138 trataram especificamente do artigo 48, parágrafo $3^{\circ}$. A Emenda $n^{\circ} 89$, de autoria do Senador Demóstenes Torres, propôs eliminar a expressão "e as condições contratuais", para que não haja tratamento privilegiado, na recuperação judicial, dos contratos de alienação fiduciária, leasing, de promessa de compra e venda, inclusive em incorporações imobiliárias, ou em contratos com reserva de domínio pelo credor. Esta Emenda foi rejeitada em razão do acolhimento da Emenda nº 107.

A Emenda $n^{\circ}$ 107, de autoria do Senador César Borges, propôs dar maior clareza à impossibilidade de venda ou retirada de bens objetos de contratos de alienação fiduciária, leasing, de promessa de compra e venda, inclusive em incorporações imobiliárias, ou em 
contratos com reserva de domínio pelo credor. A referida Emenda sugeriu que essa impossibilidade seja restrita a "bens de capital essenciais à atividade empresarial", para que fiquem excluídas as alienações fiduciárias de direitos creditórios e, assim, reduza-se o custo do crédito (grifo nosso). Esta Emenda foi aprovada.

Por fim, a Emenda ${ }^{\circ}$ 138, de autoria do Senador Tasso Jereissati, propôs excluir dos efeitos da recuperação judicial os ACC e os contratos garantidos por direitos creditórios com prazo não superior a noventa dias. Essa Emenda foi rejeitada em razão do acolhimento da Emenda n ${ }^{\circ} 107$.

No Parecer CAE $n^{\circ}$ 534, de 10.06.2004, o Senador Ramez Tabet analisou as emendas propostas e esclareceu que houve uma mudança no mercado, sendo que a turbulência e a incerteza não são características apenas da macroeconomia. $\mathrm{Na}$ esfera microeconômica - aquela que trata da constituição e interação das empresas e dos agentes individuais - a transformação no panorama é igualmente radical: a) os arranjos societários são cada vez mais complexos: empresas associam-se em crescente gigantismo, por meio de processos de concentração empresarial, com destaque para as fusões e aquisições; b) empresas importantes praticamente dispensam a propriedade de ativos físicos e tangíveis, tornando-se meramente centros de decisões mercadológicas, de desenvolvimento de produtos e de logística; c) relações contratuais mais fluidas que o direito de propriedade passam a reger as relações produtivas. Empresas abandonam, por exemplo, a propriedade do capital fixo, que é substituída por contratos de alienação fiduciária ou de arrendamento mercantil operacional (leasing operacional); d) formas tradicionais de garantia, como a hipoteca e o penhor, perdem gradualmente sua efetividade, à vista da proliferação de novas formas de contratos, como a securitização de recebíveis, a alienação fiduciária de imóveis, a cessão de direitos creditórios e os instrumentos financeiros chamados derivativos." (grifo nosso)

O Deputado esclareceu ainda que:

"A lei de falências busca conciliar dois objetivos muitas vezes conflitantes: reduzir os custos financeiros no País, por tornar mais rápidas e efetivas as execuções de garantia, e criar um ambiente favorável para que empresas sólidas, conjunturalmente em dificuldades, possam reestruturar-se economicamente e, com isso, conservar os ativos intangíveis e manter empregos. Segundo as regras 
estabelecidas para a recuperação judicial, o deferimento de seu processamento implica suspensão das ações e execuções contra o devedor pelo prazo de 180 dias. No entanto, a redação dada ao art. 48, $\S 3^{\circ}$, do PLC $n^{\circ} 71,2003$, prevê a prevalência, na recuperação judicial, das condições contratuais originais quanto a créditos garantidos por alienação fiduciária ou decorrentes de arrendamento mercantil (leasing). Com isso, faculta-se a esses credores a busca e apreensão de bens de sua propriedade que se encontrem em poder do devedor. Essa situação prejudica as chances de recuperação de empresas que dependam desses bens para a continuação de suas atividades. Tome-se como exemplo uma indústria gráfica que tenha arrendado as máquinas impressoras com as quais trabalha. Se se der o direito ao arrendador de retirar essas máquinas durante o período de suspensão que caracteriza o início da recuperação judicial, fica inviabilizado o soerguimento da empresa, pois nenhum plano de recuperação será viável se a empresa não contar nem mesmo com a maquinaria indispensável a sua produção. Por outro lado, não se pode negar aos credores proprietários o direito de reaver seus bens, sob pena de se comprometer a segurança que caracteriza esses contratos e, assim, reduzir a efetividade de instrumentos que, reconheça-se, têm proporcionado, nas modalidades de crédito com garantia mais segura ${ }^{300}$, como a alienação fiduciária, taxas de juros bastante inferiores à média praticada no País. Do ponto de vista prático, essa conciliação de interesses exige do legislador parcimônia na utilização de remédios extremos. No caso da alienação fiduciária e de outras formas de negócio jurídico em que a propriedade não é do devedor, mas do credor, é preciso sopesar a proteção ao direito de propriedade e a exigência social de proporcionar meios efetivos de recuperação às empresas em dificuldades. Por isso, propomos uma solução de equilíbrio: não se suspendem as ações relativas aos direitos dos credores proprietários, mas elimina-se a possibilidade de venda ou retirada dos bens durante os 180 dias de suspensão, para que haja tempo hábil para a formulação e a aprovação do plano de recuperação judicial. Encerrado o período de suspensão, todos os direitos relativos à propriedade são devolvidos ao seu titular. Como essas obrigações não se sujeitam à recuperação judicial, naturalmente o plano aprovado deverá prever o pagamento desses credores em condições satisfatórias, sob pena de estes exercerem o direito de retirada dos bens e inviabilizarem a empresa. A inspiração para essa solução decorre do disposto no art. 170 da Constituição, que tutela, como princípios da ordem econômica, o direito de propriedade e a sua função social." (grifo nosso)

O Senador Ramez Tabet, ao comentar a Emenda $n^{\circ} 107$, esclareceu que a emenda entendeu por bem distinguir entre bens em geral e bens de capital. O objetivo da modificação do art. 48, parágrafo $3^{\circ}$ do texto aprovado na Câmara foi evitar que a venda das instalações ou a retirada de bens, máquinas ou equipamentos inviabilizasse a recuperação das empresas. Em momento algum se quis diminuir a garantia da alienação fiduciária de créditos, permitida pela Medida Provisória no $2.160-25$, de 23 de agosto de 2001, e já utilizada com frequência pelas instituições financeiras para

\footnotetext{
${ }^{300}$ No texto original do parecer do Senador Ramez Tabet consta a expressão "sugara" provavelmente por um erro de digitação. Fizemos, portanto, a correção da referida expressão para "segura", que nos pareceu mais adequada à compreensão do texto.
} 
concessão de crédito a empresas brasileiras. Dessa forma, a redação proposta pela referida emenda é mais adequada, pois mantém a proteção às instalações, máquinas e equipamentos do devedor em recuperação judicial, mas deixa claro que não há prejuízo à garantia desses contratos, o que contribui para a expansão do crédito e a redução de seu custo no Brasil.

O Parecer CAE $n^{\circ}$ 534, de 2004 apresentou um Substitutivo, que incorporou total ou parcialmente as Emendas apresentadas. Houve a renumeração de diversos artigos, e o antigo artigo 48 passou a ser o artigo 49, com a seguinte redação:

"Art. 49. Estão sujeitos à recuperação judicial todos os créditos existentes na data do pedido, ainda que não vencidos.

(...)

$\S 3^{\circ}$ Tratando-se de credor titular da posição de proprietário fiduciário de bens móveis ou imóveis, de arrendador mercantil, de proprietário ou promitente vendedor de imóvel cujos respectivos contratos contenham cláusula de irrevogabilidade ou irretratabilidade, inclusive em incorporações imobiliárias, ou de proprietário em contrato de venda com reserva de domínio, seu crédito não se submeterá aos efeitos da recuperação judicial e prevalecerão os direitos de propriedade sobre a coisa e as condições contratuais, observada a legislação respectiva, não se permitindo, contudo, durante o prazo de suspensão a que se refere o $\$ 4^{\circ}$ do art. $6^{\circ}$, a venda ou a retirada do estabelecimento do devedor dos bens de capital essenciais a sua atividade empresarial.

$(\ldots) "$

O PLC n ${ }^{\circ}$ 71, de 2003 também tramitou na Comissão de Constituição, Justiça e Cidadania - CCJ, sendo relator o Senador Fernando Bezerra. Na CCJ não houve emendas ao artigo 49, parágrafo $3^{\circ}$. No Substitutivo do Senado (Parecer $n^{\circ}$ 691, de 06.07.2004 apresentado pela Comissão Diretora), a redação final do artigo 49, parágrafo $3^{\circ}$ permaneceu inalterada e acabou tornado-se a atual redação da LRE.

\subsubsection{Nossas Considerações sobre o Processo Legislativo}

Quando o Projeto de Lei $n^{\circ}$ 4.376/1993 tramitou na Câmara dos Deputados, por meio da Emenda Substitutiva de $n^{\circ} 102$, apresentada pelo Deputado Joavir Arantes em 27.09.1999, foi proposta nova redação ao artigo 30 do substitutivo determinando que os 
credores titulares da posição de proprietários fiduciários estariam excluídos dos efeitos da recuperação judicial do devedor. Naquele momento, parece claro que o legislador não tinha a preocupação de proteger os titulares de créditos cedidos fiduciariamente em garantia das operações de financiamento imobiliário que, naquela altura, já eram previstas pela LSFI, pois não há nenhuma menção sobre cessão fiduciária no referido projeto.

Certamente o legislador não tinha intenção de englobar naquele conceito os titulares de créditos objeto de cessão fiduciária de crédito e/ou de títulos de crédito no âmbito do mercado financeiro e de capitais, pois este instituto só foi introduzido posteriormente em nosso ordenamento jurídico pela Lei ${ }^{\circ} 10.931$, de 10.08.2004, que introduziu o artigo 66-B na Lei de Mercado de Capitais.

Quando o projeto de lei tramitou no Senado, verifica-se uma tímida menção à cessão de direitos creditórios no Parecer do Senador Ramez Tabet quando ele alega que a evolução do mercado de crédito gerou a perda gradual de efetividade das formas tradicionais de garantia, dando lugar a novas formas de garantia, como a securitização de recebíveis, a alienação fiduciária de imóveis, a cessão de direitos creditórios e os instrumentos financeiros chamados derivativos.

Ao comentar a Emenda $\mathrm{n}^{\circ}$ 107, de autoria do Senador César Borges, o Senador Ramez Tabet esclareceu que a referida Emenda teve por objetivo modificar o art. $48, \S 3^{\circ}$ do texto aprovado na Câmara para evitar que a venda das instalações ou a retirada de bens, máquinas ou equipamentos inviabilizasse a recuperação das empresas. Em momento algum se quis diminuir a garantia da alienacão fiduciária de créditos, permitida pela Medida Provisória n ${ }^{\circ}$ 2.160-25, de 23 de agosto de 2001, e já utilizada com freqüência pelas instituições financeiras para concessão de crédito a empresas brasileiras. Dessa forma, a redação proposta pela referida Emenda é mais adequada, pois mantém a proteção às instalações, máquinas e equipamentos do devedor em recuperação judicial, mas deixa claro que não há prejuízo à garantia desses contratos, o que contribui para a expansão do crédito e a reducão de seu custo no Brasil. 
Vale destacar que a Medida Provisória $n^{\circ}$ 2.160-25, de 23.08.2001 instituiu a Cédula de Crédito Bancário e acrescentou o artigo 66-A na Lei de Mercado de Capitais para instituir a alienação fiduciária em garantia de coisa fungível ou de direito. ${ }^{301} \mathrm{O}$ instituto da alienação fiduciária de coisa fungível inicialmente sofreu profundas críticas da doutrina sob o argumento de que a "fungibilidade" ofenderia a natureza jurídica do contrato de alienação fiduciária, em face da própria natureza da obrigação de restituir, que só poderia ser cumprida em relação a coisas suscetíveis de serem conservadas para retorno sem substituição por outras do mesmo gênero. Assim, a infungibilidade da coisa seria condição de eficácia da garantia. ${ }^{302}$

Com relação à alienação fiduciária de direito, parte da doutrina entendeu que o que se pretendia era possibilitar a transmissão fiduciária de direitos e de títulos de crédito em garantia, cuja forma jurídica adequada seria a cessão fiduciária, que já existe em nosso direito positivo. ${ }^{303}$ A Medida Provisória no 2.160-25/2001 acabou sendo revogada pela Lei $\mathrm{n}^{\circ}$ 10.931, de 02.08.2004, que introduziu o artigo 66-B na Lei de Mercado de Capitais que, em seu parágrafo $3^{\circ}$, manteve a alienação fiduciária de coisa fungível, mas substituiu a alienação fiduciária de direito pela a cessão fiduciária de direitos sobre coisas móveis, bem como de títulos de crédito.

\footnotetext{
301 “Art. 22. Fica acrescido o art. 66-A à Seção XIV da Lei no 4.728, de 14 de julho de 1965, com a seguinte redação:
}

Art. 66-A. Aplica-se à alienação fiduciária em garantia de coisa fungível ou de direito o disposto no art. 66, e o seguinte:

I - salvo disposição em contrário, a alienação fiduciária em garantia de coisa fungível ou de direito transferirá ao credor fiduciário a posse direta e indireta do bem alienado em garantia;

II - a alienação fiduciária em garantia de coisa fungível ou de direito valerá contra terceiros:

a) no caso de bens móveis e títulos ao portador, desde a tradição;

b) no caso de bens móveis sujeitos a registro, títulos nominativos e ações, desde a inscrição, anotação ou averbação, na forma legal;

c) no caso de créditos, desde a notificação ao devedor.

$\S 1$ No caso de inadimplemento ou mora da obrigação garantida, o fiduciário poderá vender o bem a terceiros, independentemente de leilão, hasta pública, ou qualquer outra medida judicial ou extrajudicial, salvo disposição expressa em contrário prevista no contrato, devendo aplicar o preço da venda no pagamento de seu crédito e das despesas decorrentes e entregar ao devedor, acompanhado de demonstrativo da operação realizada, o saldo apurado, se houver.

$\S 2$ Aplicam-se, no que couber, os arts. 758, 762, 763, 774, 775 e 802 do Código Civil à alienação fiduciária em garantia de coisa fungível ou de direito."

${ }^{302}$ Paulo Restiffe Neto, Garantia Fiduciária, p. 98.

303 Ver crítica feita por Gladson Mamede ("O cidadão $e$ a cédula", in http://www.buscalegis.ufsc.br/revistas/index.php/buscalegis/article/viewFile/5000/4569) quanto à redação da Medida Provisória no 2.160-25, de 23.08.2001, especialmente no tocante à alienação fiduciária de direito. $\mathrm{O}$ referido autor diz que a alienação fiduciária de direito é, no mínimo controversa, como o é a "posse de direito", já que são objetos de titularidade (que é transferida por cessão) e não de propriedade. 
Desta forma, se num primeiro momento resta claro que a intenção do legislador ao falar em "proprietário fiduciário" não era a de englobar também os titulares de créditos cedidos fiduciariamente, tal dúvida deixa de existir quando o projeto de lei tramitou no Senado, já que houve menção, ainda que tímida, no parecer do Senador Ramez Tabet sobre a preocupação em não diminuir a garantia da até então chamada "alienação fiduciária de direitos creditórios" prevista na MP n 2.160-25/2001, que foi posteriormente revogada pela Lei $n^{0}$ 10.931/2004 para substituir a alienação fiduciária de direitos pela cessão fiduciária de direitos sobre coisas móveis, bem como de títulos de crédito.

Portanto, o processo legislativo da LRE nos dá uma pista sobre a intenção do legislador em incluir a cessão fiduciária de créditos e/ou títulos de crédito, ainda que sob o errôneo título de "alienação fiduciária de direitos" dentre os créditos que não estão sujeitos aos efeitos da recuperação judicial do devedor, nos termos do parágrafo $3^{\circ}$ do artigo 49 da LRE.

\subsection{Interpretação do Artigo 49, parágrafo $3^{\circ}$ da Lei de Recuperação de Empresas}

Como já dissemos no item 4.1.3 acima, nos parece que o legislador, usando o título errôneo de "alienação fiduciária de direitos", teve a intenção de excluir os créditos cedidos fiduciariamente dos efeitos da recuperação judicial do devedor. Isto não significa, contudo, que a interpretação do artigo 49 , parágrafo $3^{\circ}$ da LRE não nos possa levar a conclusão diversa.

O tratamento da cessão fiduciária de créditos e/ou títulos de crédito na recuperação judicial do devedor passa, necessariamente, pelo exame detalhado da redação do artigo 49, parágrafo $3^{\circ}$ da LRE, principalmente com relação ao conceito de "proprietário fiduciário de bem móvel".

Já tratamos no presente trabalho do conceito de crédito e de título de crédito e não resta dúvida que ambos são considerados bens móveis por força de lei. A rigor, o detentor de um crédito é denominado titular. Assim, o credor-fiduciário detém a titularidade fiduciária dos créditos a ele cedidos. Desta forma, resta analisar se os créditos cedidos 
fiduciariamente poderiam ser abrangidos no conceito de "propriedade fiduciária". Para tanto, iniciaremos o estudo a partir do conceito de propriedade fiduciária e, posteriormente, passaremos a confrontá-lo com a titularidade fiduciária.

\subsubsection{Conceito de Propriedade Fiduciária}

A doutrina define propriedade fiduciária como uma propriedade limitada, temporária e com o escopo de garantia.

Nesse sentido é a lição de Martorell, para quem a propriedade fiduciária, como uma propriedade peculiar, caracteriza-se por uma limitação obrigatória que afeta pessoalmente o seu titular no uso de suas faculdades e geralmente sobre o tempo de duração de sua titularidade. Ele acrescenta que as características mais peculiares da propriedade fiduciária é que um direito geral, exclusivo, independente, abstrato, elástico e geralmente temporal. ${ }^{304}$

Caio Mario inclui a propriedade fiduciária como "direito real de garantia", ao lado do penhor, da hipoteca e da anticrese, e a define como sendo a transferência ao credor do domínio e posse indireta de uma coisa independentemente de sua tradição efetiva, em garantia do pagamento de obrigação a que acede, resolvendo-se o direito do adquirente com a solução da dívida garantida. A propriedade fiduciária distingue-se de outros direitos reais que se constituem em coisa alheia (o credor tem o direito de garantia mas não tem a propriedade), a propriedade fiduciária, pelo fato mesmo de sua constituição, recai sobre coisa que é então do domínio do credor, passando este a proprietário dela automaticamente. ${ }^{305}$

Melhim Chalub define a propriedade fiduciária como sendo aquela transmitida ao fiduciário com exclusão ou limitação de algumas faculdades, as quais, entretanto, podem vir a ser atribuídas ao fiduciário, dependendo da evolução do negócio em virtude do qual lhe tiver sido transmitida a propriedade em caráter fiduciário. Para ele, podem ser objeto de propriedade fiduciária bens alienáveis, podendo ser bens móveis, imóveis e os direitos de crédito. $^{306} \mathrm{O}$ referido autor salienta que quando utilizado para fins de garantia, a

\footnotetext{
${ }^{304}$ La Propriedad Fiduciaria, p. 198.

${ }^{305}$ Instituições de Direito Civil, v. IV, $19^{\mathrm{a}}$ ed., p. 426.

${ }^{306}$ Curso de Direito Civil: Direitos Reais, p. 153.
} 
propriedade fiduciária é direito acessório, pois trata-se de direito real constituído com a precípua finalidade de assegurar o cumprimento de obrigação, em geral a satisfação de um direito de crédito, por exemplo, que é o principal, ou para atender a uma outra finalidade determinada. $^{307}$

Moreira Alves defende que a propriedade fiduciária é uma nova garantia real que não se confunde com a propriedade que, em virtude do negócio fiduciário, se transmite ao credor com escopo de garantia (e que os autores em geral também denominam propriedade fiduciária), nem com qualquer dos direitos reais limitados de garantia (penhor, anticrese ou hipoteca). Para o referido autor, a propriedade fiduciária resultante da alienação fiduciária em garantia difere da propriedade plena do direito romano, assim como difere da propriedade limitada do direito germânico, pois trata-se de direito real típico - nova modalidade de propriedade limitada - que a lei criou para atender, especificamente, a determinada necessidade de ordem econômica, e não direito real que, mediante vínculo contratual ou a aposição de condição resolutiva, se subtrai à finalidade econômica para qual foi criado, utilizando-se dele para outro fim prático (o de garantia) que não o previsto na lei para aquela figura típica. ${ }^{308}$

Conclui o referido autor que a propriedade fiduciária, além de ser resolúvel, é limitada pela lei para atender ao escopo de garantia para o qual foi criada. Enquanto esse escopo perdura, a lei atua como elemento de compressão sobre o conteúdo do domínio atribuído ao credor; deixando de ser necessária a garantia, cessa a pressão, e, automaticamente, a propriedade volta à sua plenitude anterior. A propriedade fiduciária é direito acessório por natureza, porquanto se destina a assegurar a satisfação do direito de crédito, que é o principal. Daí resultam as seguintes consequiências: a) seu valor é o mesmo do direito que ela garante; b) extinto o crédito cuja satisfação assegura, extingue-se, também, a propriedade fiduciária, não sendo, todavia, verdadeira a recíproca; c) salvo disposição em contrário ou a hipótese em que a propriedade fiduciária se tenha extinguido, com a cessão do crédito, transmite-se, igualmente, essa garantia real; e d) as exceções oponíveis ao direito de crédito - assim, por exemplo, a de nulidade - se opõem também à propriedade fiduciária, mas o mesmo não se verifica em caso contrário. ${ }^{309}$

\footnotetext{
${ }^{307}$ Ibid., p. 150.

${ }^{308}$ Da Alienação fiduciária em Garantia, pp. 153 e 156.

${ }^{309}$ Ibid., pp. 166 e 168.
} 


\subsubsection{Titularidade Fiduciária x Propriedade Fiduciária}

Feitas as considerações acerca do conceito de propriedade fiduciária, passaremos a analisar qual é a relação existente entre titularidade fiduciária e propriedade fiduciária. Seriam institutos distintos, semelhantes, similares, espécie e gênero?

Para responder a esta questão, analisaremos primeiramente o significado das palavras "titularidade" e "propriedade" encontradas em dicionários jurídicos e não jurídicos. Depois, procederemos a uma análise da doutrina sobre o tema. Vejamos abaixo algumas definições encontradas:

\begin{tabular}{|c|c|c|}
\hline Dicionário & Titular / Titularidade & Proprietário / Propriedade \\
\hline $\begin{array}{l}\text { Ana Prata. Dicionário Jurídico: } \\
\text { direito civil, direito processual } \\
\text { civil, organização judiciária. } 3^{\mathrm{a}} \\
\text { ed. Coimbra: Almedina, } 1992 .\end{array}$ & $\begin{array}{l}\text { Pág. } 947 \\
\text { Diz-se que a pessoa é titular de } \\
\text { um direito quando entre este e } \\
\text { aquele existe uma relação de } \\
\text { pertença, isto é, quando se pode } \\
\text { dizer que o direito pertence a essa } \\
\text { pessoa. Em regra, o termo é } \\
\text { apenas utilizado para significar a } \\
\text { relação de pertença de um direito } \\
\boldsymbol{a} \text { um sujeito, embora, por } \\
\text { exemplo, também se encontre } \\
\text { referido a deveres ou obrigações, } \\
\text { dizendo-se então que A é titular } \\
\text { de certo dever ou de certa } \\
\text { obrigação. }\end{array}$ & $\begin{array}{l}\text { Pág. } 364 \\
\text { É o direito real que integra todas } \\
\text { as prerrogativas que se pode ter } \\
\text { sobre um bem; o proprietário goza } \\
\text { de modo pleno e exclusivo dos } \\
\text { direitos de uso, fruição e } \\
\text { disposição das coisas que lhe } \\
\text { pertencem. }\end{array}$ \\
\hline \begin{tabular}{llll} 
Aurélio & Buarque de & \multicolumn{2}{c}{ Holanda } \\
Ferreira. Novo Dicionário & $d a$ \\
Língua Portuguesa. Rio & de \\
Janeiro: Nova Fronteira, 1986 &
\end{tabular} & $\begin{array}{l}\text { Pág.1.683 } \\
\text { Qualidade de titular, sendo titular } \\
\text { o senhor, dono, possuidor de um } \\
\text { direito. }\end{array}$ & $\begin{array}{l}\text { Pág. } 1.403 \\
\text { O direito de usar, gozar e dispor } \\
\text { de bens, e de reavê-los do poder } \\
\text { de quem quer que injustamente os } \\
\text { possua. Proprietário é quem tem a } \\
\text { posse, uso, gozo e disposição. }\end{array}$ \\
\hline $\begin{array}{l}\text { Antônio Houaiss; Mauro de Salles } \\
\text { Villar; e Francisco Manoel de } \\
\text { Mello Franco. Dicionário Houaiss } \\
\text { da Língua Portuguesa. Rio de } \\
\text { Janeiro: Objetiva, 2001. }\end{array}$ & $\begin{array}{l}\text { Pág. } 2726 \\
\text { 1) qualidade, condição ou estado } \\
\text { de ser titular, em razão de título } \\
\text { conferido ou outorgado; } \\
\text { 2) posse de título, real ou ideal, } \\
\text { indicativo, representativo ou } \\
\text { comprobatório de um direito ou de } \\
\text { uma qualidade jurídica. }\end{array}$ & $\begin{array}{l}\text { Pág. } 2314 \\
\text { 1) pertença ou direito legal de } \\
\text { possuir (algo) } \\
\text { 2) direito de usar, gozar e dispor } \\
\text { de um bem, e de reavê-lo do poder } \\
\text { de quem ilegalmente o possua }\end{array}$ \\
\hline $\begin{array}{l}\text { De Plácido e Silva. Vocabulário } \\
\text { Jurídico - vol. III. } 8^{\mathrm{a}} \text { ed. Rio de }\end{array}$ & Pág. 481 & Pág. 376 \\
\hline
\end{tabular}




\begin{tabular}{|c|c|c|}
\hline Janeiro: Forense, 1984. & $\begin{array}{l}\text { Titular: Originado de título, do } \\
\text { latim titulus. Em sentido especial } \\
\text { e tecnicamente jurídico, o titular é } \\
\text { o sujeito ativo de um direito, ou o } \\
\text { credor de uma obrigação. } \\
\text { Neste conceito, pois, o titular é } \\
\text { toda pessoa que possui um direito, } \\
\text { reconhecido, ou declarado por lei } \\
\text { a seu favor. Assim, pois, o dono, o } \\
\text { proprietário, o possuidor, o } \\
\text { usuário, o usufrutuário, o } \\
\text { enfiteuta, o credor, o senhorio, o } \\
\text { locador, o locatário, enfim, } \\
\text { qualquer sujeito ativo de uma } \\
\text { obrigação, são titulares dos } \\
\text { direitos correspondentes, isto é, } \\
\text { dos direitos que lhes são } \\
\text { assegurados e reconhecidos pela } \\
\text { própria lei. } \\
\text { Por esse motivo, a titularidade } \\
\text { jurídica revela a revelação, ou a } \\
\text { dependência atual de um direito, } \\
\text { ou de uma obrigação, a um sujeito } \\
\text { de direito, ou a um credor, a quem } \\
\text { foram atribuídos por um título, } \\
\text { que os autoriza a exercitá-los. }\end{array}$ & $\begin{array}{l}\text { Proprietário: Do latim } \\
\text { proprietarius, designa a pessoa a } \\
\text { quem se atribui a qualidade do } \\
\text { senhor ou dono da coisa. É, } \\
\text { assim, a pessoa que tem o direito } \\
\text { de propriedade sobre determinada } \\
\text { coisa, móvel ou imóvel. É o } \\
\text { titular desse direito. }\end{array}$ \\
\hline $\begin{array}{l}\text { Maria Helena Diniz. Dicionário } \\
\text { Jurídico, v. } 3 \text { e 4. São Paulo: } \\
\text { Saraiva, 1998. }\end{array}$ & $\begin{array}{l}\text { Pág. } 825 \text { (v. 3) } \\
\text { Titular: ...3. Direito civil. a) } \\
\text { Sujeito ativo de um direito; b) } \\
\text { credor de uma obrigação. }\end{array}$ & $\begin{array}{l}\text { Pág. } 568 \text { (v. 4) } \\
\text { Proprietário: 1. Direito civil. a) } \\
\text { Titular do direito de usar, gozar e } \\
\text { dispor de uma coisa e de reavê-la } \\
\text { de quem a detiver injustamente; b) } \\
\text { dono do bem; c) o que tem a } \\
\text { propriedade. }\end{array}$ \\
\hline $\begin{array}{l}\text { J. M. Othon Sidou (organizador), } \\
\text { Dicionário Jurídico: Academia } \\
\text { Brasileira de Letras. } 7^{\text {a }} \text { ed. Rio de } \\
\text { Janeiro: Forense Universitária, } \\
\text { 2001. }\end{array}$ & $\begin{array}{l}\text { Pág. } 693 \\
\text { Titular do direito: Dir. Civ. Diz- } \\
\text { se daquele que possui ou adquiriu } \\
\text { um direito, integrante de seu } \\
\text { patrimônio econômico ou moral. } \\
\text { Obs. Somente o direito adquirido } \\
\text { confere a titularidade, o que não } \\
\text { ocorre com a expectativa de } \\
\text { direito. }\end{array}$ & $\begin{array}{l}\text { Pág. } 845 \\
\text { Proprietário: s.m. (Lat., de } \\
\text { proprietas). Dir. Civ. Aquele que } \\
\text { tem a propriedade de alguma coisa } \\
\text { e sobre ela exerce o direito de uso, } \\
\text { gozo e disposição. CC.art. 524; } \\
\text { CBAr, } 16 \S 1 \text {; Conv. Roma, 1952, } \\
\text { art. } 2(3) \text {. }\end{array}$ \\
\hline $\begin{array}{l}\text { Pedro dos Reis Nunes. Dicionário } \\
\text { de Tecnologia Jurídica, v. 2. } 5^{\mathrm{a}} \\
\text { ed. Rio de Janeiro: Freitas Bastos, } \\
\text { 1961. }\end{array}$ & $\begin{array}{l}\text { Pág. } 437 \\
\text { Titular: todo aquele que possui } \\
\text { um título real, ou ideal, indicativo, } \\
\text { representativo, ou comprobatório } \\
\text { do seu direito ou da sua qualidade } \\
\text { jurídica. - de direito cartular - } \\
\text { diz-se do possuidor de um título } \\
\text { de crédito. }\end{array}$ & $\begin{array}{l}\text { Pág. } 295 \\
\text { Proprietário: titular do direito de } \\
\text { propriedade. Dono; senhorio; } \\
\text { senhor e possuidor de quaisquer } \\
\text { bens. O nu proprietário, ou aquele } \\
\text { que tem o domínio direto da coisa. }\end{array}$ \\
\hline
\end{tabular}


O resultado da pesquisa demonstrou que "titularidade" é o termo utilizado para significar a relação de pertença de um direito, dever ou obrigação a um sujeito. $\mathrm{O}$ termo "propriedade" é o termo utilizado para significar o direito real que integra todas as prerrogativas que se pode ter sobre um bem. O proprietário goza de modo pleno e exclusivo dos direitos de uso, fruição e disposição das coisas que lhe pertencem.

Titularidade é, portanto, gênero, do qual a propriedade é espécie, pois todo o proprietário é também titular de um direito.

Como já exposto no decorrer da presente dissertação, a cessão fiduciária de créditos e títulos de crédito é espécie de negócio fiduciário de garantia. Assim, portanto, a análise da questão da titularidade vis-à-vis propriedade deve levar em conta o fato de que nos negócios fiduciários existem duas relações, sendo uma relação obrigacional e uma relação com eficácia real onde há a transferência plena e efetiva do direito de crédito e/ou do título de crédito ao credor-fiduciário como forma de garantia da obrigação principal.

$\mathrm{Na}$ doutrina, encontramos posições que adotam o conceito amplo de propriedade, o qual engloba a titularidade. Essa é a posição defendida por Navarro Martorell que diz ser o efeito mais importante dos negócios fiduciários a transferência de uma plena titularidade que, com uma extensão do sentido da palavra "propriedade" à titularidade plena dos direitos e dos títulos de crédito cedidos, a doutrina estrangeira, mais nutrida cada dia acerca destes temas, tem denominado "propriedade fiduciária". Martorell observa que a sua natureza, causas, efeitos nas diversas situações e relações do titular e em que medida pode ser considerada como distinta do direito de propriedade absoluto e típico, são questões gerais que se apresentam e cuja problema aparece nos ordenamentos jurídicos que acolhem um conceito absoluto de propriedade. Ele faz algumas considerações acerca da evolução do conceito de propriedade, advertindo que o conceito de "propriedade fiduciária" seria de rara compreensão se se partir de um errôneo ou antiquado conceito do instituto da propriedade em geral. ${ }^{310}$

$\overline{{ }^{310} \text { La Propriedad Fiduciaria, p. } 173 .}$ 
Martorell adverte que nos negócios fiduciários, em razão de causas alheias ao negócio em si, é necessário transmitir a plena propriedade de um bem. Não cabe discutir se é ou não propriedade o direito transmitido: é obvio que o é, porque somente o sendo é possível alcançar o fim que se pretende. A titularidade transmitida deve ser verdadeiramente propriedade, posto que haja de surtir, ao menos potencialmente, os efeitos desta. (grifo nosso) ${ }^{311}$

Do mesmo modo, Melhim Chalhub entende que a expressão "credor titular da posição de proprietário fiduciário de bens móveis ou imóveis" contida no parágrafo $3^{\circ}$ do artigo 49 da LRE deve ser entendida em sentido abrangente, compreendendo os bens corpóreos e incorpóreos, dentre eles os direitos sobre bens móveis e os títulos de crédito a que se refere o artigo 66-B da Lei de Mercado de Capitais. ${ }^{312}$

Cesar Fiuza ensina que a transmissão dos bens implica a transmissão do direito de propriedade sobre eles. Ocorre que, dentre os bens que podem ser objeto de negócio fiduciário estão direitos como, por exemplo, direitos patrimoniais de autor. Em nossa técnica jurídica, não se fala em propriedade de direitos, mas em titularidade. Destarte, a transmissão fiduciária importa a transferência do domínio ou da titularidade sobre uma ou mais coisas e/ou direitos. ${ }^{313}$

André Carvalho Nogueira observa que o conceito de propriedade num sentido restrito equivale ao domínio, que se refere ao direito de propriedade sobre coisas corpóreas. Num sentido amplo, a propriedade aplica-se a qualquer espécie de bem, inclusive a coisas incorpóreas, como direitos. Equivale ao termo "titularidade". Nesta concepção, é possível, portanto, a existência de propriedade sobre direitos pessoais, como os de crédito, por exemplo. Nestes casos, conquanto a relação entre credor e devedor seja pessoal, a relação do credor com as demais pessoas é real, ou seja, erga omnes. ${ }^{314}$

\footnotetext{
311 Ibid. p. 174.

${ }^{312}$ Negócio Fiduciário, $4^{\mathrm{a}}$ ed., p. 359.

${ }^{313}$ Alienação Fiduciária em Garantia: de acordo com a Lei $n^{\circ} 9.514 / 97$, p. 14

314 Propriedade fiduciária em garantia: o sistema dicotômico da propriedade no Brasil. In: Revista de Direito Bancário 2008, n. 39, p. 62.
} 
Francisco Eduardo Loureiro diz expressamente que a Lei ${ }^{\circ}$ 10.931/2004 fixou regime jurídico próprio, com regras específicas de direito material e processual, para os casos de propriedade fiduciária em garantia de obrigação, no qual o credor fiduciário seja instituição financeira, tendo por objeto bens móveis, tanto infungíveis como fungíveis, inclusive bens incorpóreos, como créditos. ${ }^{315}$

Ao comentar sobre os títulos de crédito, Asquini diz que a titularidade do direito cartular está ligada ao direito de propriedade sobre o título e segue a propriedade do documento. Ou seja, titular do direito cartular é quem se torna proprietário do documento. De forma análoga, os direitos fracionários separáveis do direito cartular (penhor, usufruto do crédito) competem a quem tem o correspondente direito real sobre o documento. $\mathrm{O}$ direito de propriedade aqui tratado tem a função de servir à circulação do direito cartular, sendo, portanto, um direito de propriedade que automaticamente se resolve quando, com a extinção do crédito, o título exaure sua função. ${ }^{316}$

Em vista da natureza e estrutura da cessão fiduciária em garantia, onde há efetiva transferência ao credor-fiduciário da titularidade dos créditos, estejam ou não consubstanciados em um título de crédito, enquanto perdurar a dívida contraída pelo devedor-fiduciante, cremos que razão assiste a Navarro Martorell de que o credorfiduciário é verdadeiro proprietário. Desta forma, adotamos o entendimento de que o conceito de propriedade fiduciária previsto no parágrafo $3^{\circ}$ do artigo 49 da LRE deve ser interpretado de maneira ampla para abranger, também, o credor titular dos créditos cedidos fiduciariamente.

\subsection{Posição da Doutrina e Jurisprudência sobre o Tratamento da Cessão} Fiduciária na Recuperação Judicial do Devedor

A cessão fiduciária de crédito no âmbito do mercado financeiro e de capitais tem suscitado grande debate na doutrina e na jurisprudência, identificando-se duas correntes diametralmente opostas. De um lado, parte da doutrina e da jurisprudência defendem que os credores garantidos por cessão fiduciária de créditos não estão sujeitos aos efeitos da

\footnotetext{
${ }^{315}$ In: Cezar Peluso (Coord.). Código Civil Comentado: doutrina e jurisprudência, p. 1.390.

${ }^{316}$ Titoli di Credito e in Particolare Cambiale e Titoli Bancari di Pagamento, pp. 45 e46.
} 
recuperação judicial do devedor-fiduciante. Significa dizer, portanto, que tais credores não participam e nem votam nas deliberações sobre o plano de recuperação da recuperanda, pois não estão sujeitos aos seus efeitos.

Por outro lado, parte da doutrina e da jurisprudência defendem que tais credores estão sujeitos aos efeitos da recuperação judicial do devedor-fiduciante. Os argumentos de cada uma dessas correntes serão detalhados a seguir.

\subsubsection{Corrente que Defende a Não Sujeição dos Credores Garantidos por Cessão Fiduciária aos Efeitos da Recuperação Judicial do Devedor-Fiduciante}

\subsubsection{Posição da Doutrina}

Para os defensores da primeira corrente, os credores garantidos com cessão fiduciária de créditos e de títulos de créditos estão excluídos da recuperação judicial do devedor-fiduciante pelos seguintes argumentos: primeiro, porque os direitos de crédito constituem bens móveis por força de lei, nos termos do inciso III do artigo 83 do CC e, depois, porque o conceito de "propriedade fiduciária" previsto no parágrafo $3^{\circ}$ do artigo 49 da LRE deveria ser interpretado de maneira ampla, abrangendo bens corpóreos e incorpóreos, tais como os direitos de crédito.

Dentre os defensores desta corrente, podemos destacar a opinião de Melhim Chalhub, que assevera que a lei exclui dos efeitos da recuperação de empresa os créditos cedidos fiduciariamente, prevalecendo o direito do credor-fiduciário de receber os créditos cedidos até o integral pagamento do seu crédito. A exclusão decorre da LRE, estando compreendidos no parágrafo $3^{\circ}$ do artigo 49 os credores que ocupam a posição de proprietário fiduciário de bens móveis e imóveis e alcançados pelo inciso IX do artigo 119 da LRE os bens e direitos integrantes do patrimônio de afetação. Como bem salienta Melhim, a expressão empregada na LRE “credor titular da posição de proprietário fiduciário de bens móveis ou imóveis" deve ser entendida em sentido abrangente, compreendendo os bens corpóreos e incorpóreos, entre eles os direitos sobre bens móveis 
e os títulos de crédito a que se refere o artigo 66-B da Lei de Mercado de Capitais, com a redação dada pelo artigo 50 da Lei ${ }^{\circ} 10.931 / 2004 .{ }^{317}$

Conclui o referido autor que a exclusão desses créditos dos efeitos da falência e do procedimento de recuperação da empresa decorre não só da segregação que constitui efeito inerente à própria natureza de toda e qualquer garantia fiduciária, seja sobre bens, móveis ou imóveis, ou direitos, como também de previsão específica contida na legislação especial sobre a matéria, que, na hipótese de falência do devedor-cedente-fiduciante, assegura ao credor-cessionário-fiduciário a restituição dos títulos que eventualmente estiverem na posse daquele, após o que "prosseguirá o cessionário fiduciário no exercício de seus direitos na forma do disposto nesta seção" (LSFI, art. 20 e seu parágrafo único), sendo esses direitos os de receber os créditos diretamente e aplicar o respectivo produto na satisfação do seu crédito com todos os encargos, entregando ao devedor-fiduciante o saldo que porventura restar (LSFI, artigo 18 e ss.). ${ }^{318}$

Melhim Chalhub, em artigo publicado no Jornal Valor Econômico de 24.07.2009, também observa que existem pelo menos quatro fundamentos legais a confirmar que os créditos objeto de cessão fiduciária estão compreendidos na norma do parágrafo $3^{\circ}$ do artigo 49 da LRE e, portanto, estão excluídos dos efeitos da recuperação judicial. O primeiro deles é o inciso III do artigo 83 do CC, que classifica os "direitos pessoais patrimoniais" (aí estão os créditos) como bens móveis para os efeitos legais e, na medida em que integram essa classe, os créditos objeto de propriedade (titularidade) fiduciária estão compreendidos na norma de exclusão do parágrafo $3^{\circ}$ do artigo 49 da LRE. ${ }^{319}$

Depois, em relação à cessão fiduciária, a legislação respectiva dispõe que: 1) o contrato de cessão fiduciária opera a transferência ao credor da titularidade dos créditos cedidos, até a liquidação da dívida garantida; 2) as quantias recebidas são apropriadas pelo credor fiduciário, e não pelo devedor fiduciante; e 3) é assegurado ao credor continuar recebendo os créditos, mesmo em caso de falência da empresa cedente fiduciante, até a liquidação da dívida garantida - conforme o artigo 66B e parágrafos da Lei de Mercado de Capitais, e os artigos 18 a 20 da LSFI. Está claro, assim, que os créditos objeto de cessão

\footnotetext{
${ }^{317}$ Negócio Fiduciário, $4^{\mathrm{a}}$ ed., p. 359.

318 Ibid., p. 360.

${ }^{319}$ A cessão fiduciária e a recuperação judicial, publicado no Jornal Valor Econômico de 24.07.2009.
} 
fiduciária permanecem no patrimônio do credor, sob afetação, até que cumpram sua destinação, imunes aos efeitos de uma eventual falência ou recuperação judicial da empresa devedora fiduciante. Além disso, a tipificação da titularidade fiduciária afasta qualquer possibilidade de sua equiparação ao penhor. ${ }^{320}$

Fabio Ulhoa Coelho também defende a não sujeição dos credores garantidos por cessão fiduciária de créditos aos efeitos da recuperação judicial do devedor-fiduciante sob o argumento de que os direitos são, por lei, considerados espécies de bens móveis, não havendo nenhum dissenso doutrinário a esse respeito. Se a lei quisesse eventualmente circunscrever a exclusão aos efeitos da recuperação judicial à titularidade fiduciária sobre bens corpóreos, teria se valido dessa categoria jurídica, ou mesmo da expressão equivalente "coisa", pois esta restringe-se a bens corpóreos. ${ }^{321}$

O referido autor relembra a distinção feita por Pontes de Miranda entre direitos reais de garantia e direitos reais em garantia. Os direitos reais de garantia são o penhor, hipoteca e a anticrese, enquanto os direitos reais em garantia são a alienação fiduciária em garantia e a cessão fiduciária de direitos creditórios. Enquanto os direitos reais de garantia procuram assegurar o cumprimento de obrigação mediante a instituição de um direito real titulado pelo credor sobre bem da propriedade do devedor, nos direitos reais em garantia, o cumprimento da obrigação é garantido pela transferência do bem onerado à propriedade do credor, que passa a deter a propriedade resolúvel do bem. Diz o referido autor que o parágrafo $3^{\circ}$ do artigo 49 da LRE disciplina os direitos dos credores titulares de direito real em garantia, enquanto que no parágrafo $5^{\circ}$ deste dispositivo são disciplinados os dos titulares de direito real de garantia. Assim, a permanência em conta vinculada durante o prazo de suspensão das execuções é determinado, pela lei, para os créditos garantidos por um tipo de direito real de garantia, que é o penhor. Esta restrição não se estende aos créditos garantidos por direito real em garantia. A diferença de tratamento é plenamente justificável, à medida que, neste último caso, o credor, por ser o proprietário (titular) do bem (ou direito) dado em garantia, goza da proteção constitucional liberada ao direito de propriedade. Já no primeiro, o proprietário do bem gravado pela garantia real é ainda o devedor. $^{322}$

\footnotetext{
${ }^{320}$ Ibid.

${ }^{321}$ Comentários à Lei de Falências e de Recuperação de Empresas, $7^{\mathrm{a}}$ ed., p. 150.

${ }^{322}$ Ibid., pp. 154 e 155.
} 
Eduardo Secchi Munhoz também defende a não sujeição dos créditos cedidos fiduciariamente aos efeitos da recuperação judicial do devedor-fiduciante, mas entende que tais créditos são essenciais à continuidade da empresa e, portanto, devem ser depositados em conta vinculada à recuperação, durante o prazo de 180 dias de suspensão das ações e execuções contra o devedor, podendo aplicar-se a regra de substituição de garantias prevista no parágrafo $5^{\circ}$ do artigo 49 da LRE, dada a natureza fungível do bem objeto da garantia. $^{323}$

Jean Carlos Fernandes defende a não sujeição dos credores garantidos por cessão fiduciária com base no argumento de que a cessão fiduciária é modalidade de negócio jurídico de constituição de propriedade fiduciária, preferindo-se, por técnica jurídica, quando se tratar de cessão fiduciária de direitos, falar-se em titularidade de direitos, deixando o termo propriedade para quando a garantia incidir sobre bens móveis ou imóveis. ${ }^{324}$

O referido autor observa que o parágrafo $3^{\circ}$ do artigo 66-B da Lei de Mercado de Capitais, ao admitir a alienação fiduciária de coisa fungível e a cessão fiduciária de direitos sobre coisas móveis, bem como de títulos de crédito, refere-se a: a) posse direita e indireta do bem objeto da propriedade fiduciária; b) ou posse do título representativo do direito ou do crédito (p.ex. título de crédito); c) podendo o credor, em caso de inadimplemento ou mora da obrigação garantida, vender a terceiros o bem objeto da propriedade fiduciária. Note-se, assim, que ao fazer referência à propriedade fiduciária, o dispositivo da Lei de Mercado de Capitais o faz de forma genérica ou em sentido lato, englobando tanto a alienação fiduciária quanto a cessão fiduciária. Então, se a legislação prevê a existência dessas duas modalidades de negócio fiduciário (alienação fiduciária e cessão fiduciária), pela mesma razão a exceção prevista pela LRE, em seu artigo $49, \S 3^{\circ}$, contempla ambas as espécies. $^{325}$

\footnotetext{
${ }^{323}$ Cessão Fiduciária de Direitos de Crédito e a Recuperação Judicial da Empresa. In: Revista do Advogado $\mathrm{n}^{\circ}$ 105, ano XXIX, Setembro de 2009, p. 46.

${ }^{324}$ Cessão Fiduciária de Títulos de Crédito: a Posição do Credor Fiduciário na Recuperação Judicial da Empresa, p. 195.

${ }^{325}$ Ibid., p. 197.
} 
Finalmente, cumpre ressaltar que para Jean Fernandes não se aplica ao credorendossatário-fiduciário a exigência de manter em conta vinculada os valores eventualmente recebidos com a realização da garantia, pois tal hipótese, prevista no $\$ 5^{\circ}$ do mesmo artigo 49 da LRE, aplica-se somente a crédito sujeito aos efeitos da recuperação judicial, ou seja, quando se tratar de crédito garantido por penhor sobre títulos de crédito, direitos creditórios, aplicações financeiras ou valores mobiliários. ${ }^{326}$

Ernesto Antunes de Carvalho é da opinião de que os credores titulares de títulos representativos de direitos ou de crédito, previsto na Lei no $10.931 / 2004$ estão excluídos da recuperação judicial. ${ }^{327}$

No mesmo sentido, Sérgio Campinho ensina que pelo contrato de cessão fiduciária em garantia, opera-se a transferência ao credor da titularidade dos créditos cedidos, até a liquidação da dívida garantida. Continua este autor dizendo que a cessão fiduciária de direito sobre coisas móveis ou sobre título de crédito vem normatizada nos $\S \S 3^{\circ}$ e $4^{\circ}$ do art. 66-B da Lei de Mercado de Capitais, com a redação atribuída pela Lei 10.931/04. Sobre tais operações são aplicáveis os princípios dos artigos 18 e 20 da LSFI acima destacados. Assim, de forma geral, podemos dizer que quando a alienação fiduciária em garantia tiver por objeto direito de crédito passa a ser por lei denominada de cessão fiduciária, sobre a qual se aplica o instituto da restituição, demonstrada a posse injusta da massa exercida sobre os títulos de propriedade do credor requerente. ${ }^{328}$

Glauber Talavera, em artigo publicado no Jornal Valor Econômico sobre negócio fiduciário, registra que há resistência de alguns poucos quanto ao aperfeiçoamento do instituto do negócio fiduciário, pois entendem devida a inclusão do credor fiduciário no quadro geral de credores, mais especificamente na classe de credores com garantia real, na hipótese de recuperação judicial. Para o autor, este entendimento discricionário é contrário à essência e antagônico ao sopro vital do negócio fiduciário. ${ }^{329}$

\footnotetext{
${ }^{326}$ Ibid., p. 199.

${ }^{327}$ Contratos Bancários e a Nova Lei de Falências. In: WAISBERG, Ivo (Coord.); FONTES, Marcos Rolim Fernandes (Coord.). Contratos Bancários, p. 396.

${ }^{328}$ Falência e Recuperação de Empresa, p. 393.

329 O Negócio Fiduciário e a Recuperação Judicial, artigo publicado no Jornal Valor Econômico de 29.01.2008.
} 
Alexandre Bonamim, em artigo publicado no Jornal Valor Econômico, opina que o crédito do credor fiduciário, seja ele proprietário fiduciário em garantia de coisas corpóreas ou titular fiduciário em garantia de coisas incorpóreas de caráter patrimonial, como direitos creditórios, não se submete aos efeitos da recuperação judicial, nos termos do artigo 49, parágrafo $3^{\circ}$ da LRE. Argumentar que direitos creditórios, objeto de titularidade fiduciária em garantia, não são bens móveis e que, por isso, deveriam se sujeitar aos efeitos da recuperação judicial, significa desconsiderar: 1) o artigo 83, inciso III do CC; 2) a melhor doutrina; 3) a jurisprudência majoritária; 4) o fato de que tanto a propriedade fiduciária em garantia de coisas corpóreas quanto a titularidade fiduciária em garantia de coisas incorpóreas são espécies do gênero propriedade fiduciária; e 5) a intenção do legislador e, por conseguinte, o espírito da LRE. E mais: significa adicionar um fator desestabilizador nos dias atuais de crise econômica internacional, não contribuindo para a superação do represamento do crédito. ${ }^{330}$

\subsubsection{Posição da Jurisprudência}

Os Tribunais de Justiça dos Estados de São Paulo, Paraná e Goiás têm decidido favoravelmente à exclusão dos credores garantidos por cessão fiduciária de créditos dos efeitos da recuperação judicial do devedor-fiduciante.

Já os Tribunais dos Estados do Rio de Janeiro e Mato Grosso têm decisões divergentes. Parte de suas decisões são favoráveis à exclusão dos credores garantidos por cessão fiduciária dos efeitos da recuperação judicial do devedor-fiduciante, enquanto outras decisões dos referidos Tribunais ou têm desconstituído a cessão fiduciária de créditos, igualando-a ao penhor de recebíveis, ou têm decidido à favor da inclusão da cessão fiduciária aos efeitos da recuperação judicial do devedor-fiduciante.

Selecionamos alguns acórdãos de cada um dos referidos Tribunais, a seguir transcritos:

${ }^{330}$ O Credor Fiduciário e a Recuperação Judicial. Artigo publicado no Jornal Valor Econômico de 17.12.2008. 


\section{A. Tribunal de Justiça do Estado de São Paulo - TJSP}

“EXECUÇÃO - RECUPERAÇÃO JUDICIAL DA DEVEDORA - DESCABIMENTO DA SUSPENSÃO DA EXECUÇÃO QUANTO À PARTE DO CRÉDITO NÃO SUJEITA À RECUPERAÇÃO JUDICIAL, EM RAZÃO DE CESSÃO FIDUCIÁRIA DE DUPLICATAS (ART. 49, § 3 DA LEI N 11.101/05) - RECURSO PROVIDO EM PARTE." (TJSP, 15 Câmara, Agravo de Instrumento $\mathrm{n}^{\mathrm{o}}$ 7.222.504-8, julgado em 19.02.2008, relator Des. Cyro Bonilha.)

"RECUPERAÇÃO JUDICIAL - CONTRATOS COM GARANTIA REAL (ALIENAÇÃO FIDUCIÁRIA E PENHOR DE DUPLICATAS) - REQUERIMENTO DE DESBLOQUEIO DE IMPORTÂNCIAS RETIDAS PELO BANCO AGRAVADO - INDEFERIMENTO - INCIDENCIA DO DISPOSTO NO ARTIGO 49, $\S \S 3^{\circ}$ E $5^{\circ}$, DA LEI 11.101/05, OU SEJA, DE UM LADO, O CREDOR TITULAR DA POSIÇÃO DE PROPRIETÁRIO FIDUCIÁRIO DE BEM MÓVEL NÃO SE SUBMETE AOS EFEITOS DA RECUPERAÇÃO JUDICIAL, DEVENDO PREVALECER OS DIREITOS DE PROPRIEDADE SOBRE A COISA E AS CONDIÇÕES CONTRATUAIS, OBSERVADA A LEGISLAÇÃO RESPECTIVA, E, DO OUTRO, TRATANDO-SE DE CRÉDITO GARANTIDO POR PENHOR SOBRE TÍTULOS DE CRÉDITO, PODERÃO SER SUBSTITUÍDAS OU RENOVADAS AS GARANTIAS LIQUIDADAS OU VENCIDAS DURANTE A RECUPERAÇÃO JUDICIAL E, ENQUANTO NÃO RENOVADAS OU SUBSTITUÍDAS, O VALOR EVENTUALMENTE RECEBIDO EM PAGAMENTO DAS GARANTIAS PERMANECERÁ EM CONTA VINCULADA DURANTE O PERÍODO DE SUSPENSÃO DE QUE TRATA O $\$ 4^{\circ}$ DO ART. $6^{\circ}$ DA MESMA LEI - AGRAVO DE INSTRUMENTO NÃO PROVIDO." (TJSP, Câmara Especial de Falências e Recuperações Judiciais, Agravo de Instrumento $\mathrm{n}^{\circ}$ 557.256-4/0-00, julgado em 30.07.2008, relator Des. Romeu Ricupero.)

"RECUPERAÇÃO JUDICIAL - DESPACHO JUDICIAL QUE DEFERIU O DESBLOQUEIO DE BENS POR PARTE DO AGRAVANTE, LIBERANDO-OS PARA A AGRAVADA E RECUPERANDO - INADMISSIBILIDADE - CÉDULA DE CRÉDITO BANCÁRIO COM CONTRATO DE CONSTITUIÇÃO DE ALIENAÇÃO FIDUCIÁRIA EM GARANTIA (CESSÃO FIDUCIÁRIA DE DIREITOS DE CRÉDITO) - OS DIREITOS DE CRÉDITOS SÃO BENS MÓVEIS PARA OS EFEITOS LEGAIS (ART. 83, III, DO CC) E SE INCLUEM NO \& $3^{\circ} D O$ ART. 49 DA LEI 11.101/2005 - PROPRIEDADE FIDUCIÁRIA CONSTITUÍDA COM O REGISTRO DO CONTRATO - APLICAÇÃO DO DISPOSTO NO ART. 49, $\S \S 3^{\circ}$ E $5^{\circ}$, DA LEI 11.101/2005 - RECURSO INTERPOSTO TEMPESTIVAMENTE, OU SEJA, DENTRO DO PRAZO LEGAL, CONTADO A PARTIR DO DIA EM QUE O AGRAVANTE TEVE EFETIVAMENTE VISTA DOS AUTOS - AGRAVO DE INSTRUMENTO CONHECIDO E PROVIDO." (TJSP, Câmara Especial de Falências e Recuperações Judiciais, Agravo de Instrumento $\mathrm{n}^{\circ}$ 585.273-4/7-00, julgado em 19.11.2008, relator Des.Romeu Ricupero.) 
"AGRAVO DE INSTRUMENTO - MEDIDA CAUTELAR INOMINADA RECUPERAÇÃO JUDICIAL - PRETENDIDA A LIBERAÇÃO DA GARANTIA FIDUCIÁRIA - IMPOSSIBILIDADE - INTELIGÊNCIA DO ART. 49, § $3^{\circ}$ DA LEI 11.101/05 - DECISÃO MANTIDA - RECURSO NÃO PROVIDO.” (TJSP, 15 Câmara, Agravo de Instrumento $n^{\circ}$ 7.328.969-5, julgado em 17.03.2009, relator Des. Edgard Jorge Lauand.)

“RECUPERAÇÃO JUDICIAL - CESSÃO FIDUCIÁRIA DE TÍTULOS DE CRÉDITO E DE DIREITOS CREDITÓRIOS - ESPÉCIE DE ALIENAÇÃO FIDUCIÁRIA EM GARANTIA - LEI N ${ }^{\circ}$ 9.514/97, ART 17, II, E ART. 66-B, § 4, DA LEI $N^{\circ} 4$ 728/65 - APLICABILIDADE DOS §\$ $3^{\circ} E 4^{\circ}$ DO ART 49 DA LEI 11 101/2005 - RECURSO IMPROVIDO.” (TJSP, Câmara Especial de Falências e Recuperações Judiciais, Agravo de Instrumento $\mathrm{n}^{\circ}$ 630.475-4/0, julgado em 09.06.2009, relator Des.Elliot Akel.)

"RECUPERAÇÃO JUDICIAL. CONTRATO DE PARCERIA COMERCIAL. TRADICIONAL OPERAÇÃO DE CARTÃO DE CRÉDITO. DESPACHO JUDICIAL DE LIBERAÇÃO DE TRAVA BANCÁRIA, AFASTANDO A MANUTENÇÃO DE GARANTIA SOBRE RECEBÍVEIS FUTUROS. INADMISSIBILIDADE. INTELIGENNCIA DO DISPOSTO NO ART. 49, § $2^{\circ} D A$ LEI 11.101/2005. FIDELIDADE AO PRINCÍPIO DA OBRIGATORIEDADE DAS CONVENÇÕES LIVREMENTE PACTUADAS. ASSIM, ATÉ QUE O PLANO DE RECUPERAÇÃO SEJA APROVADO E VENHA A MODIFICAR O PACTUADO, OS CONTRATOS CELEBRADOS ANTERIORMENTE AO REQUERIMENTO DA RECUPERAÇÃO JUDICIAL DEVEM SER ESTRITAMENTE OBSERVADOS TAL COMO LIVREMENTE AJUSTADOS. AGRAVO DE INSTRUMENTO PROVIDO EM PARTE, SEM RECONHECIMENTO DE QUE, APÓS O PEDIDO DE RECUPERAÇÃO JUDICIAL, OS VALORES GERADOS SERIAM EXTRACONCURSAIS". (TJSP, Terceiro Grupo Cível, Agravo de Instrumento $\mathrm{n}^{\circ}$ 627.613-4/4-00, julgado em 28.07.2009, relator Des. Romeu Ricupero).

Encontramos algumas decisões que aplicam à cessão fiduciária de crédito o disposto no parágrafo $5^{\circ}$ do artigo 49 da LRE, ou seja, a necessidade de manutenção dos valores dos créditos cedidos fiduciariamente depositados em conta vinculada do devedorfiduciante durante os 180 dias de suspensão das ações e execuções contra o devedorfiduciante (stay-period $)^{331}$. Nesse sentido, vejamos algumas decisões:

\footnotetext{
${ }^{331}$ Como bem observa Paulo Fernando C. S. de Toledo (Recuperação Judicial, a principal inovação da Lei de Recuperação de Empresas - LRE. In: Revista do Advogado no 83, ano XXV, Setembro de 2005, p. 105), no caso de falência, como todos os créditos devem submeter-se ao concurso universal, como regra, não faz mesmo sentido o prosseguimento de ações ou execuções individuais dos credores. E igualmente não se justifica na recuperação judicial a continuidade das demandas. Todo o passivo, ressalvadas as exceções legais, deve ser pago na forma constante do plano de recuperação. O período de suspensão perdura por 180 dias, a contar do deferimento do processamento da recuperação judicial. Espera o legislador que nesse prazo já tenha havido uma decisão acerca do plano, de modo que, se este ainda não tiver sido aprovado, nem tiver sido decretada a falência, poderão os credores dar prosseguimento às demandas movidas contra o devedor, ou ajuizar novas. Não seria correto fazer com que os credores aguardassem por um prazo indeterminado a definição da situação do devedor.
} 
"RECUPERAÇÃO JUDICIAL - CREDOR QUE É TITULAR DE CRÉDITO GARANTIDO POR CESSÃO FIDUCIÁRIA DE DIREITOS CREDITÓRIOS CONTRA TERCEIRO - PAGAMENTOS RELATIVOS À GARANTIA QUE DEVEM SER FEITOS MEDIANTE DEPÓSITO EM CONTA VINCULADA À RECUPERAÇ̃̃O - ART. 49, § 5०, DA LEI $N^{\circ}$ 11.101/2005 - RECURSO DESPROVIDO" (TJSP, Câmara Especial de Falências e Recuperações Judiciais, Agravo de Instrumento $\mathrm{n}^{\mathrm{o}}$ 622.432-4/1-00, julgado em 06.10.2009, relator Des. Elliot Akel.)

"RECUPERAÇÃO JUDICIAL - CESSÃO FIDUCIÁRIA DE CRÉDITOS CREDOR NÃO SUJEITO AOS EFEITOS DA RECUPERAÇÃO HIPÓTESE, ENTRETANTO, DE DEPÓSITO DAS QUANTAS RECEBIDAS EM CONTA VINCULADA NO PERÍODO DE SUSPENSÃO PREVISTO NO ART $6^{\circ} . \S 4^{\circ}, D A$ LEI 11.101/05.

RECUPERAÇÃO JUDICIAL - DEPÓSITO EM CONTA VINCULADA QUE NÃO SIGNIFICA DEPÓSITO EM CONTA JUDICIAL - MANTENÇA DO VALOR SOB RESPONSABILIDADE DO CREDOR, DESDE QUE COM ATUALIZAÇÃO MONETÁRIA E JUROS DAS CADERNETAS DE POUPANÇA. RECURSO PARCIALMENTE PROVIDO." (TJSP, Câmara Especial de Falências e Recuperações Judiciais, Agravo de Instrumento $\mathrm{n}^{\circ}$ 540.384-4/4-00, julgado em 07.05.2008, relator Des. Jose Araldo da Costa Telles.)

"RECUPERAÇÃO JUDICIAL - CREDOR TITULAR DE CRÉDITO GARANTIDO POR CESSÃO FIDUCIÁRIA DE DIREITOS CREDITÓRIOS CONTRA TERCEIRO - PAGAMENTOS RELATIVOS À GARANTIA QUE DEVEM SER FEITOS MEDIANTE DEPÓSITO EM CONTA VINCULADA À RECUPERAÇÃO - ART 49, $\S 5^{\circ}$ DA LEI $N^{\circ}$ 11.101/2005 - RECURSO DESPROVIDO." (TJSP, Câmara Especial de Falências e Recuperações Judiciais, Agravo de Instrumento n ${ }^{\circ} 630.478$ 4/4-00, julgado em 06.10.2009, relator Des. Elliot Akel.)

Por outro lado, parte da jurisprudência entende inadmissível que o credor (instituição financeira) mantenha os valores depositados em conta-vinculada do devedorfiduciante durante o stay-period. Importante mencionar que a própria Câmara Especial de Falências e Recuperações Judiciais do Tribunal de Justiça do Estado de São Paulo tem entendimento divergente sobre este tema. Vejamos os acórdãos encontrados nesse sentido:

"RECUPERAÇÃO JUDICIAL. DECISÃO QUE, AO DETERMINAR O PROCESSAMENTO DO PEDIDO DA DEVEDORA, DETERMINOU O DEPÓSITO EM CONTA VINCULADA DOS VALORES DE TÍTULOS CEDIDOS FIDUCIARIAMENTE AO CREDOR. INADMISSIBILIDADE. APLICAÇÃO DO § $3^{\circ}$ DO ART. 49 DA LEI 11.101/05. RECURSO PROVIDO." (TJSP, Câmara Especial de Falências e Recuperações Judiciais, Agravo de Instrumento no $547.893-$ 4/8-00, julgado em 27.08.2008, relator Des. Boris Kauffmann.) 
"RECUPERAÇÃO JUDICIAL. DETERMINAÇÃO DE TRANSFERÊNCIA, PARA CONTA VINCULADA, DOS VALORES QUE FOREM RECEBIDOS APÓS O PEDIDO DE RECUPERAÇÃO JUDICIAL, EM RELAÇÃO AOS CRÉDITOS OBJETO DE CESSÃO FIDUCIARIA. INADMISSIBILIDADE. CRÉDITOS QUE NÃO SE SUJEITAM À RECUPERAÇÃO JUDICIAL (LEI 11.101/05, ART. 49, § $3^{\circ}$ ). RECURSO PROVIDO, NA PARTE CONHECIDA." (TJSP, Câmara Especial de Falências e Recuperações Judiciais, Agravo de Instrumento $n^{\circ}$ 548.032-4/7-00, julgado em 27.08.2008, relator Des. Boris Kauffmann.)

"RECUPERAÇÃO JUDICIAL - DESPACHO JUDICIAL DETERMINANDO A BANCO O ESTORNO DE QUANTIAS QUE TERIAM SIDO INDEVIDAMENTE APROPRIADAS - INADMISSIBILIDADE - CÉDULA DE CRÉDITO BANCÁRIO COM ANEXO DE CESSÃO FIDUCIÁRIA DE DIREITOS DE CRÉDITO - OS DIREITOS DE CRÉDITOS SÃO BENS MÓVEIS PARA OS EFEITOS LEGAIS (ART. 83, III, DO CC) E SE INCLUEM NO § $3^{\circ}$ DO ART. 49 DA LEI 11.101/2005 - PROPRIEDADE FIDUCIÁRIA CONSTITUÍDA COM O REGISTRO DO CONTRATO - APLICAÇÃO DO DISPOSTO NO ART. 49, § $3^{\circ}$ DA LEI 11.101/2005 - AGRAVO DE INSTRUMENTO PROVIDO.” (TJSP, Câmara Especial de Falências e Recuperações Judiciais, Agravo de Instrumento $n^{\circ}$ 632.8134/9-00, julgado em 09.06.2009, relator Des.Romeu Ricupero.)

\section{B. Tribunal de Justiça do Estado do Paraná - TJPR}

“RECUPERAÇÃO JUDICIAL. LEI N ${ }^{\circ} 11.101$, DE 2005. CRÉDITOS SUJEITOS À RECUPERAÇÃO JUDICIAL. CESSÃO FIDUCIÁRIA SOBRE DIREITOS CREDITÓRIOS. INTELIGÊNCIA DO ART. 49, §5 . RECURSO PROVIDO. NA DICÇÃO DO ART. 49, §5 DA LEI $N^{\circ}$ 11.101, DE 2005, OS DIREITOS CRÉDITÓRIOS GARANTIDOS PELA CESSÃO FIDUCIÁRIA NÃO SE SUBMETEM AOS EFEITOS DA RECUPERAÇÃO JUDICIAL." (TJPR, 17 Câmara Cível, Agravo de Instrumento no 471.823-6, julgado em 27.05.2009, relator Des. Lauri Caetano da Silva.)

“AGRAVO DE INSTRUMENTO. RECUPERAÇÃO JUDICIAL. CESSÃO FIDUCIÁRIA SOBRE DIREITOS CREDITÓRIOS. RECEBÍVEIS DE CARTÃO DE CRÉDITO. FUNDAMENTAÇÃO. SUFICIENTE. SUBMISSÃO DO CRÉDITO AOS EFEITOS DA RECUPERAÇÃO JUDICIAL. INOCORRENNCIA. RECURSO PROVIDO." (TJPR, 17 a Câmara Cível, Agravo de Instrumento n ${ }^{\circ}$ 472.495-6, julgado em 16.07.2008, relator Des. Vicente Del Prete Misurelli.)

"AGRAVO DE INSTRUMENTO - RECUPERAÇÃO JUDICIAL - CÉDULA DE CRÉDITO BANCÁRIO - CESSÃO FIDUCIÁRIA DE DIREITOS CREDITÓRIOS RECEBÍVEIS DE CARTÃO DE CRÉDITO - CRÉDITO QUE NÃO SUBMETE AO PROCEDIMENTO DA RECUPERAÇÃO JUDICIAL - LEVANTAMENTO DE VALORES PELA RECUPERANDA - PERDA DO OBJETO EM FACE DO JULGAMENTO DO AI N $N^{o}$ 472.508-8 - RECURSO PREJUDICADO." (TJPR, $18^{\mathrm{a}}$ 
Câmara Cível, Agravo de Instrumento n 493.027-8, julgado em 27.08.2008, relator Des. Ruy Muggiati.)

"AGRAVO DE INSTRUMENTO - RECUPERAÇÃO JUDICIAL - CÉDULA DE CRÉDITO BANCÁRIO - CESSÃO FIDUCIÁRIA DE DIREITOS CREDITÓRIOS RECEBÍVEIS DE CARTÃO DE CRÉDITO - PRELIMINAR DE NULIDADE DA DECISÃO POR AUSÊNCIA DE FUNDAMENTAÇÃO REPELIDA - CRÉDITO QUE NÃO SE SUBMETE AO PROCEDIMENTO DA RECUPERAÇÃO JUDICIAL - INTELIGÊNCIA DO ART. 49, § $3^{\circ}$ DA LEI N ${ }^{\circ}$ 11.101/2005 - RETENÇÃO DOS VALORES PELO CESSIONÁRIO NO PERCENTUAL PACTUADO POSSIBILIDADE - DECISÃO REFORMADA 1. SE AS QUESTÕES POSTAS PELA PARTE FORAM OBJETO DE EXAME NA DECISÃO, EXPONDO O JUIZ, CLARA E OBJETIVAMENTE, AS RAZÕES DE SEU CONVENCIMENTO, EM ESTRITA OBSERVÂNCIA AO ART. 93, INC. IX DA CONSTITUIÇÃO FEDERAL, NÃO SE PODE COGITAR DE NULIDADE POR AUSÊNCIA DE FUNDAMENTAÇÃO. 2. O CRÉDITO GARANTIDO POR NEGÓCIO FIDUCIÁRIO, ESPECIFICAMENTE, CESSÃO FIDUCIÁRIA DE DIREITOS CREDITÓRIOS NÃO SE SUBMETE AO PROCEDIMENTO DE RECUPERAÇÃO JUDICIAL DA EMPRESA DEVEDORA, POR EXPRESSA PREVISÃO LEGAL (ART. 49, $\S 3^{\circ}$ DA LEI N ${ }^{o}$ 11.101/05). 3. RECURSO CONHECIDO E PROVIDO.” (TJPR, 18 ${ }^{\mathrm{a}}$ Câmara Cível, Agravo de Instrumento $\mathrm{n}^{\circ}$ 472.508-8, julgado em 27.08.2008, relator Des. Ruy Muggiati.)

\section{Tribunal de Justiça do Estado de Goiás - TJGO}

"AGRAVO DE INSTRUMENTO. RECUPERACAO JUDICIAL. EXCLUSAO DE CREDITOS FIDUCIARIOS. POSSIBILIDADE. CONFORME ESTABELECE A NOVA LEI DE FALENCIAS (ARTIGO 48, § 3), NAO SE SUJEITAM A RECUPERACAO JUDICIAL OS CRÉDITOS FIDUCIÁRIOS, NAO SENDO NECESSÁRIO QUE ESTES SEJAM GARANTIDOS POR BENS MÓVEIS OU IMÓVEIS, VEZ QUE PODEM POSSUIR COMO GARANTIA UM DIREITO, COM A TRANSFERENCIA DA SUA TITULARIDADE. AGRAVO CONHECIDO E IMPROVIDO." (TJGO, 4 Câmara Cível, Agravo de Instrumento n 60965-0/180, julgado em 10/4/2008, relator Des. Carlos Escher.)

\section{Tribunal de Justiça do Estado de Mato Grosso - TJMT}

"AGRAVO DE INSTRUMENTO - RECUPERAÇÃO JUDICIAL. PRELIMINAR DE INTEMPESTIVIDADE DO AGRAVO - REJEITADA. CREDOR DE CÉDULA DE CRÉDITO BANCÁRIO - POSIÇÃO DE PROPRIETÁRIO FIDUCIÁRIO DE BEM MÓVEL - EXCLUSÃO DOS EFEITOS DA RECUPERAÇÃO JUDICIAL INTELIGÊNCIA DO ART. 49, § $3^{\circ}$ DA LEI N ${ }^{\circ}$ 11.101/2005. RECURSO PROVIDO. Por força do $\$ 3^{\circ}$, art. 49, da Lei $n^{\circ} 11.101 / 05$, o crédito de Cédula de Crédito Bancário, daquele que ocupa posição de proprietário fiduciário de bens móveis, não se submete aos efeitos da recuperação judicial. O transcurso do prazo suspensivo previsto no art. $6^{o}, \S 4^{o}$ da Lei $n^{o} 11.101 / 2005$ autoriza o credor a 
continuar a realizar seu crédito, objeto de cessão fiduciária." (TJMT, 6 Câmara Cível, Agravo de Instrumento ${ }^{\circ}$ 91370/2008, julgado em 11.03.2009, relator Des. Juracy Persiani.)

\section{E. Tribunal de Justiça do Estado do Rio de Janeiro - TJRJ}

"DIREITO EMPRESARIAL. CONTRATO DE FINANCIAMENTO COM GARANTIA DE CESSÃO FIDUCIÁRIA DE DUPLICATAS. IMPOSSIBILIDADE LEGAL DA ADMINISTRAÇÃO DESSES RECURSOS PELA EMPRESA RECUPERANDA. APLICAÇÃO DO DISPOSTO NO § 3, DO ARTIGO 49, DA LEI $N^{o}$ 11.101/2005. CRÉDITO NÃO SUJEITO À RECUPERAÇÃO DA EMPRESA.

1- Se o contrato de financiamento é garantido por cessão fiduciária de duplicatas, ao proprietário fiduciário é atribuída a posse direta e indireta do título representativo do direito ou do crédito.

2- O proprietário fiduciário não pode ser indisponibilizado do seu crédito, que se insere na exceção prevista no $\$ 3^{\circ}$, do artigo 49, da Lei $n^{o} 11.101 / 2005$, o qual expressamente exclui dos efeitos da recuperação judicial os direitos decorrentes da cessão fiduciária.

3- Não pode prevalecer, pois, decisão que impõe a transferência para uma conta de titularidade da empresa Recuperanda de valores decorrentes de liquidação das duplicatas dadas em garantia ao financiamento, posto que não proferida com a lei que informa o procedimento de recuperação judicial.

4- Agravo de Instrumento provido." (TJRJ, 20a Câmara Cível, Agravo de Instrumento $\mathrm{n}^{\mathrm{o}}$ 2009.002.21927, julgado em 14.10.2009, relatora Des. Jacqueline Lima Montenegro)

"DIREITO EMPRESARIAL. RECUPERAÇÃO JUDICIAL. CONTRATOS DE CESSÃO FIDUCIÁRIA EM GARANTIA DE DIREITOS CREDITÓRIOS. LEI N ${ }^{\circ}$ 11.101/05, ART. 49, PARÁGRAFO 3‥ A CESSÃO FIDUCIÁRIA, COMO ESPÉCIE DE PROPRIEDADE FIDUCIÁRIA, TRANSFERE AO CREDOR FIDUCIÁRIO A PROPRIEDADE DO CRÉDITO, RAZÃO PELA QUAL NÃO PODE ESSE LHE SER INDISPONIBILIZADO, DESTINADO AO PAGAMENTO DE DÍVIDAS ORDINÁRIAS DA EMPRESA EM REGIME DE RECUPERAÇÃO. AINDA QUE A POSSE DO CRÉDITO ESTEJA EM PODER DO DEVEDOR, SUA PROPRIEDADE É DO CREDOR, DAÍ PORQUE HÁ DE SER EXCLUÍDO DA RECUPERAÇÃO JUDICIAL. RECURSO PROVIDO.” (TJRJ, $17^{\mathrm{a}}$ Câmara Cível, Agravo de Instrumento $\mathrm{n}^{\circ}$ 2009.002.09750, julgado em 24.06.2009, relatora Des. Luisa Cristina Bottrel Souza) 


\subsubsection{Corrente que Defende a Sujeição dos Credores Garantidos por Cessão Fiduciária aos Efeitos da Recuperação Judicial do Devedor-Fiduciante}

\subsubsection{Posição da Doutrina}

Para os defensores da segunda corrente, que é minoritária tanto na doutrina quanto na jurisprudência, os credores garantidos por cessão fiduciária de créditos e de títulos de créditos estão incluídos na recuperação judicial do devedor-fiduciante porque, em princípio, todos os credores deveriam estar sujeitos à recuperação judicial do devedor e as exceções à regra deveriam ser interpretadas restritivamente. Os defensores desta corrente argumentam que a redação do parágrafo $3^{\circ}$ do artigo 49 da LRE não menciona expressamente a "cessão fiduciária de crédito e/ou título de crédito" e, portanto, a interpretação de "proprietário fiduciário de bens móveis" contida no parágrafo $3^{\circ}$ do artigo 49 da LRE deveria ser feita restritivamente, não abrangendo a titularidade fiduciária detida pelos credores garantidos por cessão fiduciária.

Paulo Restiffe Neto e Paulo Sérgio Restiffe são adeptos desta corrente e argumentam que tais créditos estão incluídos na recuperação judicial do devedorfiduciante, pois não gozam do tratamento deferido pelo parágrafo $3^{\circ}$ do artigo 49 da LRE à posição privilegiada de quem seja proprietário fiduciário de bens móveis ou imóveis, de não se submeter aos efeitos da referida recuperação. Os referidos autores fundamentam sua posição mediante a diferenciação entre direitos reais sobre objeto alheio e direitos reais sobre coisa própria. Observam que a cessão fiduciária de títulos de crédito prevista no artigo 66-B, parágrafo $3^{\circ}$ da Lei de Mercado de Capitais é um instituto de garantia sobre direito alheio, isto é, sobre direito do credor de título de crédito resultante de qualquer negócio jurídico, inclusive o decorrente de contratos de alienação de imóveis (art. 17, II e $\S 1^{\circ}$ da LSFI). Já a cessão do crédito objeto de alienação fiduciária prevista no artigo 28 da LSFI implica a transferência ao cessionário de todos os direitos e obrigações inerentes à propriedade fiduciária em garantia, vale dizer, direito real dominial, em coisa própria, porque alienada fiduciariamente em garantia ao credor. 
Acrescentam, ainda, que o título é a causa ou fundamento jurídico de um direito, sendo a titularidade a aptidão para o exercício de ato correspondente a um direito, visando a produzir determinados efeitos jurídicos. Essa linha de entendimento que reconhece a distinção entre propriedade e titularidade prevaleceu na redação acrescida do artigo 1.368A do CC: "as demais espécies de propriedade fiduciária ou de titularidade fiduciária submetem-se à disciplina específica das respectivas leis especiais, somente se aplicando as disposições deste Código naquilo que não for incompatível com a legislação especial." Assim, a expressão "titularidade" do artigo 18 da LSFI não implica "propriedade", salvo se estivesse explícita essa qualidade para o efeito de transferência por cessão fiduciária ali apontada "ao credor".

Concluem dizendo que é inadequada a atribuição da qualificação de "propriedade fiduciária" ao cessionário de título de crédito quando não se trate de direito real em coisa própria, mas sim de cessão fiduciária de direito real em coisa alheia, isto é, que não é de propriedade do cessionário fiduciário garantido. Toda a diferença reside nessa peculiaridade: se é coisa alheia não é de propriedade do cessionário. E só os proprietários gozam do privilégio do parágrafo $3^{\circ}$ do artigo 49 da LRE. ${ }^{332}$

Lincoln Estevam, em artigo publicado no Jornal Valor Econômico, defende que apenas na alienação fiduciária o credor assume a condição de proprietário fiduciário da coisa, pois a propriedade fiduciária somente pode ser constituída sobre a coisa, e não sobre o direito/crédito. $\mathrm{O}$ referido autor defende que a alienação fiduciária e cessão fiduciária são institutos distintos, pois a Lei de Mercado de Capitais expressamente os distinguiu. Então, se a legislação prevê a existência dessas duas modalidades distintas de negócio fiduciário (alienação fiduciária e cessão fiduciária), pela mesma razão a exceção prevista pela LRE deveria contemplar ambas as espécies. Mas o legislador não desejou assim, excluindo da recuperação judicial apenas e tão somente o credor titular da posição de proprietário fiduciário de bens móveis ou imóveis. Não se pode, portanto, interpretar essa regra, seja por analogia ou por extensão, para abranger, também, a figura do credor cessionário dos títulos de crédito, pois a interpretação restritiva das exceções é regra elementar de compreensão e aplicação das normas jurídicas. ${ }^{333}$

\footnotetext{
${ }^{332}$ Propriedade Fiduciária Imóvel, p. 36 e 37.

${ }^{333}$ Trava Bancária e Recuperação de Empresas, artigo publicado no Jornal Valor Econômico de 23.09.2008.
} 
No mesmo sentido, Fernando de Luizi e Luiz Gustavo Bacelar, em artigo publicado no Jornal Tribuna do Direito, opinam que apenas na alienação fiduciária o credor assume a condição de proprietário fiduciário da coisa, pois a propriedade fiduciária somente pode ser constituída sobre a coisa (e não sobre o direito), motivo pelo qual a figura do proprietário fiduciário de coisas móveis ou imóveis (de que trata a exceção prevista pelo artigo 49, parágrafo $3^{\circ}$ da LRE) não se confunde com a figura do cessionário fiduciário de direitos e/ou títulos de crédito. ${ }^{334}$

\subsubsection{Posição da Jurisprudência}

O Tribunal de Justiça do Estado do Espírito Santo foi o primeiro a se posicionar favoravelmente à inclusão dos credores garantidos por cessão fiduciária de créditos na recuperação judicial do devedor-fiduciante:

"PROPRIEDADE FIDUCIÁRIA DE TÍTULOS DE CRÉDITO. SUJEIÇÃO AOS EFEITOS DA RECUPERAÇÃO JUDICIAL. NÃO INCIDÊNCIA DA EXCEÇÃO PREVISTA NA LEGISLAÇÃO FALIMENTAR.

1. A redação do artigo 49, $\S 3^{\circ}$, da Lei $n^{\circ}$ 11.101/2005 estatui, claramente, que os créditos daqueles em posição de proprietário fiduciário de bem móvel e imóvel não se submetem aos efeitos da recuperação judicial.

2. Assim como o próprio agravante insiste em afirmar em suas razões recursais, o mesmo se revela como proprietário fiduciário de títulos de crédito que, por óbvio, não se confundem com a classificação de bens móveis ou imóveis.

3. Se a legislação admite a cessão fiduciária tanto de coisa móvel quanto, como no caso em apreço, de títulos de crédito, deveria esta última hipótese também estar prevista, de modo expresso pela lei específica, como excluída dos efeitos da recuperação judicial, o que não é o caso." (TJES, $3^{\text {a }}$ Câmara Cível, Agravo de Instrumento $\mathrm{n}^{\mathrm{o}}$ 030089000142, julgado em 24.08.2008, relator Des. Jorge Góes Coutinho)

Encontramos outra decisão nesse sentido do Tribunal de Justiça do Estado de Minas Gerais, em que apesar de não ter sido configurada a cessão fiduciária de créditos no caso em questão, o Desembargador Maurício Barros, em seu voto, argumenta que a cessão fiduciária de títulos de crédito não se encontra na exceção prevista no $\S 3^{\circ}$ do artigo 49 da LRE. Vejamos a ementa do referido acórdão e parte do voto do Desembargador Maurício Barros:

\footnotetext{
${ }^{334}$ Alienação Fiduciária x Cessão Fiduciária, artigo publicado no Jornal a Tribuna do Direito de novembro de 2008 .
} 
"EMENTA: AGRAVO DE INSTRUMENTO - RECUPERAÇÃO JUDICIAL DE EMPRESA - CESSÃO FIDUCIÁRIA - AUSÊNCIA DE PROVA CONCLUSIVA DE QUE OS VALORES DEPOSITADOS EM CONTA CORRENTE DA RECUPERANDA SE REFEREM A CÉDULA DE CRÉDITO BANCÁRIO SUBMISSÃO DO CRÉDITO AO PLANO DE RECUPERAÇÃO - RECURSO NÃO PROVIDO. Estão sujeitos à recuperação judicial todos os créditos da empresa recuperanda, inclusive aqueles anteriores ao pedido de recuperação judicial, salvo as exceções legais previstas nos parágrafos $3^{\circ}$ e $4^{o}$ do artigo 49 da Lei $n^{o}$ 11.011/2005. Hipótese em julgamento em que não se provou, de forma conclusiva, que os valores depositados na conta corrente da recuperanda se referem a cessão fiduciária, devendo, em razão disso, se submeter ao plano de recuperação, pois não se enquadram nas exceções legais. (TJMG, 6 Câmara Cível, Agravo de Instrumento $\mathrm{n}^{\mathrm{o}}$ 1.0109.08.012108-9/001(1), julgado em 09.06.2009, relator Des. Maurício Barros)

"VOTO:

(...)

Conheço do recurso, por estarem presentes os pressupostos de admissibilidade.

Segundo a agravada, o recorrente está exercendo a autotutela de seus créditos, apropriando-se de valor existente em uma das três contas correntes mantidas junto à instituição financeira, para amortizar saldo devedor existente nas duas outras.

Por outro lado, sustenta o agravante que tais créditos lhe pertencem, em razão da cessão fiduciária estabelecida em contrato de cédula de crédito bancário, sendo, assim, proprietário fiduciário, não estando tais créditos, portanto, submetidos aos efeitos da recuperação judicial, uma vez que excepcionados no $\S 3^{\circ}$ do artigo 49 da Lei de Falências, que assim dispõe.

"Tratando-se de credor titular da posição de proprietário fiduciário de bens móveis ou imóveis, de arrendador mercantil, de proprietário ou promitente vendedor de imóvel cujos respectivos contratos contenham cláusula de irrevogabilidade ou irretratabilidade, inclusive em incorporações imobiliárias, ou de proprietário em contrato de venda com reserva de domínio, seu crédito não se submeterá aos efeitos da recuperação judicial e prevalecerão os direitos de propriedade sobre a coisa e as condições contratuais, observada a legislação respectiva, não se permitindo, contudo, durante o prazo de suspensão a que se refere o $\$ 4^{o}$ do art. $6^{\circ}$ desta Lei, a venda ou a retirada do estabelecimento do devedor dos bens de capital essenciais a sua atividade empresarial."

Antes de mais nada, para que se possam admitir os argumentos do agravante, tais créditos, no importe de $R \$ 1.221 .000,00$, existentes numa das três contas correntes da agravada, só poderiam ter origem no pagamento de títulos que lhes teriam sido transferidos em cessão fiduciária.

Fixada tal premissa, já nesse primeiro questionamento existem condições de decidir a questão, não sendo necessário adentrar nos demais argumentos da agravada e do administrador judicial, notadamente a validade da cessão fiduciária e o registro do instrumento.

Para comprovar a sua tese, juntou o recorrente vários extratos bancários que, a princípio, não demonstram a tese alegada, bem como uma relação de difícil visualização dos títulos (fl. 142/147) que estariam na carteira de cobrança - e que seriam os recebidos e que geraram o saldo apropriado - e que pertenceriam ao agravante, em cessão fiduciária. 
Entretanto, da análise da prova documental, não há como firmar um Juízo de certeza acerca do fato de que foram tais créditos que formaram o saldo retido pelo banco agravante. Melhor dizendo, não há como ter certeza se os $R \$ 1.221 .000,00$ existentes na conta corrente se referem a numerário correspondente aos créditos cedidos, ou seja, se há ligação entre o valor de R\$1.221.000,00 com os títulos cedidos em garantia.

Nesse ponto, sou obrigado a concordar com o alegado, quando alegou, na contraminuta que, se os títulos foram dados ao agravante deve ser esclarecido quais são esses títulos, contra quem foram sacados, qual são o valor e o vencimento de cada um, e quais títulos compõem o valor reclamado de $R \$ 1.221 .000,00$.

Assim, como o agravante não provou de plano que o saldo de $R \$ 1.221 .000,00$ possui estrita correlação com títulos cedidos pela agravada, não há como ser acolhida a pretensão recursal.

Para tanto, seria necessária uma prova pericial para se comprovar se o saldo utilizado pelo agravante foi obtido através dos títulos cedidos, o que se mostra inviável no agravo de instrumento.

Não obstante tal fundamento, apto a ensejar o desprovimento do agravo, por amor do debate apresento outro fundamento para igualmente desprover o recurso, $e$ que é o seguinte: a cessão fiduciária de títulos de créditos não se encontra na exceção prevista no $\$ 3^{\circ}$ do artigo 49 da Lei de Falências.

Com efeito, procede a afirmação do Administrador judicial, em sua manifestação, de que tais bens móveis (títulos de crédito) não se inserem dentre aqueles mencionados no referido artigo.

Transcrevo, mais uma vez, o referido parágrafo $3^{\circ}$ :

"Tratando-se de credor titular da posição de proprietário fiduciário de bens móveis ou imóveis, de arrendador mercantil, de proprietário ou promitente vendedor de imóvel cujos respectivos contratos contenham cláusula de irrevogabilidade ou irretratabilidade, inclusive em incorporações imobiliárias, ou de proprietário em contrato de venda com reserva de domínio, seu crédito não se submeterá aos efeitos da recuperação judicial e prevalecerão os direitos de propriedade sobre a coisa e as condições contratuais, observada a legislação respectiva, não se permitindo, contudo, durante o prazo de suspensão a que se refere o $\$ 4^{\circ}$ do art. $6^{\circ}$ desta Lei, a venda ou a retirada do estabelecimento do devedor dos bens de capital essenciais a sua atividade empresarial."

Além de não constar, nesse dispositivo legal, expressamente, a expressão títulos de crédito, como afirmado pelo administrador judicial, pelo que se percebe da parte final do dispositivo legal, está o legislador se referindo a bens móveis materiais, pois dispõe sobre retirada do estabelecimento, o que não se aplica aos títulos de crédito, pois os créditos em geral são bens móveis imateriais. Em suma, os títulos de crédito cedidos fiduciariamente pela recuperanda sujeitam-se à recuperação judicial.

Com esses fundamentos, nego provimento ao recurso.

Custas recursais, pelo agravante.

É como voto." (grifos nossos) 
Como já mencionado anteriormente, os Tribunais de Justiça dos Estados do Rio de Janeiro e de Mato Grosso possuem decisões nos dois sentidos. Existem decisões favoráveis à exclusão dos credores garantidos por cessão fiduciária de crédito dos efeitos da recuperação judicial do devedor-fiduciante e, por outro lado, existem decisões desconstituindo a cessão fiduciária de créditos para equipará-la ao penhor de crédito ou no sentido de sujeitá-la aos efeitos da recuperação judicial do devedor-fiduciante. Vejamos abaixo as ementas dos acórdãos encontrados nesse sentido:

\section{A. Tribunal de Justiça do Estado do Rio de Janeiro - TJRJ}

"DIREITO EMPRESARIAL. RECUPERAÇÃO JUDICIAL DE EMPRESA. CREDOR QUE SE APRESENTA COMO PROPRIETÁRIO FIDUCIÁRIO MAS, NA VERDADE, É CREDOR PIGNORATÍCIO. SUJEIÇÃO DOS CRÉDITOS GARANTIDOS POR PENHOR AO PROCESSO DE RECUPERAÇÃO. LEGITIMIDADE DA DECISÃO JUDICIAL QUE AUTORIZA O LEVANTAMENTO DE METADE DOS RECEBÍVEIS, LIBERANDO TAIS VERBAS DO MECANISMO CONHECIDO COMO “TRAVA BANCÁRIA”. APLICAÇÃO DOS PRINCÍPIOS DA PRESERVAÇÃO DA EMPRESA E DA FUNÇÃO SOCIAL DO CONTRATO. RECURSO A QUE SE NEGA PROVIMENTO." (TJRJ, 2 Câmara, Agravo de Instrumento no 2009.002.01890, julgado em 18.02.2009, relator Des. Alexandre Freitas Câmara).

"DIREITO EMPRESARIAL. RECUPERAÇÃO JUDICIAL DE EMPRESA. CREDOR QUE SE APRESENTA COMO PROPRIETÁRIO FIDUCIÁRIO MAS, NA VERDADE, É CREDOR PIGNORATÍCIO. SUJEIÇÃO DOS CRÉDITOS GARANTIDOS POR PENHOR AO PROCESSO DE RECUPERAÇÃO. LEGITIMIDADE DA DECISÃO JUDICIAL QUE AUTORIZA O LEVANTAMENTO DE METADE DOS RECEBÍVEIS, LIBERANDO TAIS VERBAS DO MECANISMO CONHECIDO COMO “TRAVA BANCÁRIA”. APLICAÇÃO DOS PRINCÍPIOS DA PRESERVAÇÃO DA EMPRESA E DA FUNÇÃO SOCIAL DO CONTRATO. RECURSO A QUE SE NEGA PROVIMENTO.” (TJRJ, $2^{\mathrm{a}}$ Câmara, Agravo de Instrumento no 2009.002.02081, julgado em 25.03.2009, relator Des. Alexandre Freitas Câmara).

Ainda com relação à divergência encontrada no Tribunal de Justiça do Estado do Rio de Janeiro, importante mencionar a ementa do voto vencido do Desembargador Elton Martinez Carvalho Leme no Agravo de Instrumento n. ${ }^{\circ}$ 2009.002.09750, julgado em 24.06.2009: 
"AGRAVO DE INSTRUMENTO. DIREITO EMPRESARIAL. RECUPERAÇÃO JUDICIAL. DECISÃO QUE OBSTA A SATISFAÇÃO DO CRÉDITO DO AGRAVANTE COM VALORES PROVENIENTES DA CONTA-CORRENTE DA AGRAVADA. PRINCÍPIO DA PRESERVAÇÃO DA EMPRESA. MANUTENÇÃO DA DECISÃO. 1. Assegurar o prosseguimento da atividade econômica da empresa em regime de recuperação judicial é medida imprescindivel ao atendimento da finalidade da lei, que impõe sacrifícios a tantos que se relacionem à empresa em condições tais. 2. A sistemática da Lei $n^{\circ} 11.101 / 2005$ objetiva recompor a saúde financeira do empresário ou da sociedade, resguardando a continuidade de suas atividades, como preconizam os princípios da preservação e da função social da empresa. Por tal razão, somente de modo excepcional determinados credores, expressamente indicados na legislação, escaparão dos efeitos limitadores da recuperação judicial. 3. Se é certo que as normas que imprimem exceção à regra geral devem ser interpretadas restritivamente, na análise da exceção contida no $\$$ $3^{\circ}$ do art. 49 da Lei de Recuperação Judicial deve-se considerar que a propriedade fiduciária de bens ali tratada é aquela conceituada no art. 1.361 do Código Civil e não a das leis especiais, como a Lei $n^{o}$ 4.728/65 e o Decreto-lei $n^{\circ}$ 911/69, que disciplinam a propriedade fiduciária sobre coisas móveis fungíveis e infungíveis quando o credor fiduciário for instituição financeira, ou ainda a Lei $n^{\circ}$ 9.514/97, que regula a propriedade fiduciária sobre bens imóveis, quando os protagonistas forem ou não instituições financeiras. 4. O crédito do agravante, instituição financeira, decorrente de contrato de "Cédula de Crédito Bancário (Mútuo)", garantido por "Instrumento Particular de Cessão Fiduciária em Garantia de Direitos Creditórios - Cartão de Crédito/Débito" tem natureza pignoratícia e está sujeito às regras da recuperação. 5. No caso, a titularidade dos direitos creditórios sobre as receitas derivadas de cartões de crédito/débito não saiu da esfera patrimonial da agravada, permanecendo temporariamente como garantia da dívida e comprometendo apenas receitas no limite do débito, sem esgotar a totalidade dessas receitas, que retornam ao credor originário com a quitação da obrigação: trata-se de operação conhecida como "trava bancária", tendo como garantia recebíveis futuros que, na prática, ficam retidos pelo banco, em conta vinculada, a fim de quitar o empréstimo originador da operação. 6. Recurso a que se nega provimento."

\section{B. Tribunal de Justiça do Estado do Mato Grosso - TJMT}

“RECURSO DE AGRAVO DE INSTRUMENTO - RECUPERAÇÃO JUDICIAL PRELIMINAR DE NÃO CONHECIMENTO - REJEIÇÃO - PRESCINDIBILIDADE DA JUNTADA DE PROCURAÇÃO OUTORGADA PELO AGRAVADO SE O MESMO AINDA NÃO INTEGRAVA A RELAÇÃO PROCESSUAL ORIGINÁRIA MÉRITO - NÃO EXCLUSÃO DA CESSÃO FIDUCIÁRIA DOS EFEITOS DA RECUPERAÇÃO JUDICIAL QUE SE IMPÕE - NECESSIDADE DE VIABILIZAÇÃO DA SUPERAÇÃO DA SITUAÇÃO DE CRISE ECONÔMICAFINANCEIRA DO DEVEDOR - AGRAVO PROVIDO.

- Despicienda a exigência de certidão dando conta de que a parte contrária não integrara a relação processual originária, para admissão e conhecimento do agravo de instrumento interposto, mormente se o recurso restou instruído com cópia integral dos autos onde fora proferida a interlocutória objurgada; 
- A finalidade imediata da Lei $n^{\circ}$ 11.101/2005 é a de franquear ao empresário mecanismo apto a permitir a superação da crise econômico-financeira de sua empresa, de modo que sendo os Agravados credores na recuperação judicial deferida, devem a ela se submeterem para o recebimento dos seus créditos representados pelos CDB's, duplicatas e outros direitos creditórios cedidos em garantia, sem qualquer privilégio (princípio da par conditio creditorum);

- Admitindo a legislação a cessão fiduciária tanto de coisa móvel quanto, como no caso em apreço, de títulos de crédito, deveria esta última hipótese também estar prevista, de modo expresso pela lei específica, como excluída dos efeitos da recuperação judicial, o que não é o caso. (TJMT, 2a Câmara Cível, Agravo de Instrumento $\mathrm{n}^{\mathbf{o}}$ 31659/2009, julgado em 02.09.2009, relator Des. Cirio Miotto).

\subsubsection{Nossas Considerações sobre o Tema}

A cessão fiduciária de títulos de crédito e/ou de direitos creditórios passou a ser largamente utilizada pelas instituições financeiras como garantia de seus empréstimos a partir da edição da Lei $\mathrm{n}^{\mathrm{o}}$ 10.931, de 02.08.2004, que inseriu o artigo 66-B na Lei de Mercado de Capitais.

A cessão fiduciária de créditos apresentou-se como uma garantia mais vantajosa do que o penhor de direitos creditórios e/ou de títulos de crédito até então utilizado, pois sua eficácia não depende da notificação do devedor e, depois, porque a maior parte da doutrina e da jurisprudência tem aceitado que a cessão fiduciária de créditos não está sujeita aos efeitos da recuperação judicial do devedor-fiduciante, por interpretação do parágrafo $3^{\circ}$ do artigo 49, da LRE, opinião da qual também somos partidários pelas razões que passaremos a expor.

Da análise do processo legislativo da LRE no tocante ao parágrafo $3^{\circ}$ do artigo 49, nos pareceu que o legislador, usando o título errôneo de "alienação fiduciária de direitos", teve a intenção de excluir os créditos cedidos fiduciariamente dos efeitos da recuperação judicial do devedor.

Sob o ponto de vista jurídico, acreditamos que no conceito de "proprietário fiduciário de bens móveis" previsto no parágrafo $3^{\circ}$ do artigo 49 da LRE estão também incluídos os credores titulares de créditos e/ou títulos de créditos cedidos fiduciariamente, pelas seguintes razões: 
Primeiro, porque há consenso na doutrina de que tanto créditos como títulos de créditos são bens móveis, por força do disposto no artigo 83, inciso III do CC.

Depois, porque a cessão fiduciária de créditos e/ou títulos de crédito é modalidade de negócio fiduciário, onde há a efetiva transferência da titularidade dos referidos créditos para o cessionário, que o torna verdadeiro proprietário. Como bem observou Navarro Martorell, não cabe discutir se é ou não propriedade o direito transmitido: é obvio que o é, porque somente o sendo é possível alcançar o fim que se pretende. A titularidade transmitida deve ser verdadeiramente propriedade, posto que haja de surtir, ao menos potencialmente, os efeitos desta. (grifo nosso $)^{335}$

A transferência da titularidade e/ou da propriedade com o fim de garantia é característica peculiar dos negócios fiduciários onde há uma contradição e excesso entre o meio empregado e o fim visado. Nas palavras de Francesco Ferrara usa-se um meio mais forte para obter um resultado mais fraco, emprega-se uma forma jurídica mais importante para obter um efeito menor. A essência do negócio fiduciário vai mais além da finalidade das partes, que supera a intenção prática, que tem mais consequiências jurídicas do que as seriam necessárias para se alcançar o fim em vista. ${ }^{336}$

Desta forma, em que pese a autoridade de Paulo Restiffe Neto e Paulo Sérgio Restiffe, não nos parece razoável admitir-se que a cessão fiduciária de créditos e de títulos de crédito prevista no artigo 66-B da Lei de Mercado de Capitais estaria incluída nos efeitos da recuperação judicial do devedor, em razão de ter por objeto "direito sobre coisa alheia" isto é, direito do credor de título de crédito resultante de qualquer negócio jurídico.

Isto porque, quando os créditos (consubstanciados ou não em títulos de crédito) são cedidos fiduciariamente à instituição financeira, há a modificação do credor da antiga relação jurídica e, desta forma, a instituição financeira passa a deter a plena titularidade de tais créditos, ainda que tais créditos tenham se originado de um negócio jurídico prévio entre cedente e o devedor do cedente. Tanto é assim, que o devedor do cedente poderá opor à instituição financeira as exceções que lhe competirem, bem como as que, no momento

\footnotetext{
${ }^{335}$ La propriedad fiduciaria, p. 174.

${ }^{336}$ A simulação dos negócios jurídicos, tradução de A. Bossa, p. 78.
} 
em que veio a ter conhecimento da cessão, tinha contra o cedente, consoante dispõe o artigo 294 do CC.

Com relação ao argumento de que titularidade fiduciária difere de propriedade fiduciária, somos da opinião de que titularidade é gênero do qual propriedade fiduciária é espécie. Ademais, adotamos o conceito amplo de propriedade, que poderá abranger tanto bens corpóreos quanto incorpóreos, tais como o crédito.

Também somos contrários à posição defendida por Eduardo Munhoz e também adotada por alguns Desembargadores do TJSP, de que os créditos cedidos fiduciariamente são considerados "bens de capital" e, portanto, deveriam permanecer depositados em conta vinculada à recuperação, durante o prazo de 180 dias de suspensão das ações e execuções contra o devedor, podendo aplicar-se a regra de substituição de garantias prevista no parágrafo $5^{\circ}$ do artigo 49 da LRE, dada a natureza fungível do bem objeto da garantia.

Embora por razões de justiça e, na tentativa de viabilizar a recuperação judicial da devedora, alguns Desembargadores do TJSP tenham entendido que os créditos cedidos fiduciariamente são essenciais à recuperação judicial da devedora e, portanto, deveriam permanecer depositados em conta vinculada à recuperação durante o stay-period, sob o ponto de vista estritamente jurídico não nos parece que tal opinião possa prevalecer.

Além de ser questionável a inclusão de dinheiro na definição de "bens de capital", nos parece que a redação da parte final do parágrafo $3^{\circ}$ do artigo 49 da $\operatorname{LRE}^{337}$ trata das hipóteses em que os bens de capital objeto da garantia continuam na posse direta do devedor, tais como máquinas e equipamentos de todo o tipo. Neste caso, é razoável que tais bens não possam ser retirados da posse direta do devedor, pois sem eles o devedor não poderia continuar a exercer sua atividade, inviabilizando sua recuperação judicial. No entanto, no caso de créditos cedidos fiduciariamente, a posse direta e indireta de tais

\footnotetext{
337 “Art. 49, $\S 3^{\circ}$ - Tratando-se de credor titular da posição de proprietário fiduciário de bens móveis ou imóveis, de arrendador mercantil, de proprietário ou promitente vendedor de imóvel cujos respectivos contratos contenham cláusula de irrevogabilidade ou irretratabilidade, inclusive em incorporações imobiliárias, ou de proprietário em contrato de venda com reserva de domínio, seu crédito não se submeterá aos efeitos da recuperação judicial e prevalecerão os direitos de propriedade sobre a coisa e as condições contratuais, observada a legislação respectiva, não se permitindo, contudo, durante o prazo de suspensão a que se refere $o$ $\$ 4^{0}$ do art. $6^{-}$desta Lei, a venda ou a retirada do estabelecimento do devedor dos bens de capital essenciais a sua atividade empresarial."
} 
créditos passa a ser detida pela instituição financeira, razão pela qual não entendemos serem aplicáveis as restrições previstas na parte final do parágrafo $3^{\circ}$ do artigo 49 da LRE e no parágrafo $5^{\circ}$ do artigo 49 da LRE.

Por fim, questão controversa é saber qual seria o tratamento a ser dado aos créditos cedidos fiduciariamente que ainda não se venceram, bem como os créditos futuros previamente cedidos, mas que ainda não se materializaram, caso o devedor-fiduciante ingresse com pedido de recuperação judicial e tenha o processamento do referido pedido deferido pelo juiz.

Como já mencionado no decorrer desta dissertação, a lei permite que a instituição financeira receba diretamente dos devedores do devedor-fiduciante as importâncias relativas aos créditos cedidos fiduciariamente. Por óbvio, a instituição financeira somente poderá cobrar os valores relativos aos créditos que já são exigíveis. Tendo em vista que na cessão fiduciária de créditos há a transferência plena e efetiva dos referidos créditos ao cessionário, acreditamos ser defensável que a instituição financeira, como plena titular dos referidos créditos, possa cobrá-los a posteriori, quando de seu vencimento, permanecendo tais créditos fora dos efeitos da recuperação judicial do devedor-fiduciante.

Com relação aos créditos futuros que ainda não se materializaram, como já mencionado no item 3.2.3 da presente dissertação, somos partidários da teoria da transmissão que sustenta que no caso de celebração de uma cessão prévia de créditos futuros, não se verifica a constituição direta do crédito na esfera jurídica do cessionário, verificando-se antes essa constituição na esfera jurídica do cedente, onde o crédito permanece por um segundo lógico, sendo, porém, imediatamente a seguir transferido para o cessionário, em virtude do negócio de cessão anteriormente celebrado. $\mathrm{O}$ credor fiduciário tem apenas um direito expectativo de vir a se tornar titular do referido crédito. $\mathrm{O}$ cessionário só virá a adquirir o direito se o cedente, sem a cessão, o tivesse adquirido. ${ }^{338}$

\footnotetext{
${ }^{338}$ Carlos Alberto da Mota Pinto, Cessão de Contrato: contendo parte tratando a matéria conforme o direito brasileiro, p. 191.
} 
Significa dizer, portanto, que o cedente só terá como responsabilizar-se pela existência do crédito futuro no momento em que este vier a nascer e que será, portanto, nos termos da teoria da transmissão, o momento em que tal crédito será de fato transmitido ao cessionário, não estando sujeito aos efeitos da recuperação judicial do devedor-fiduciante.

Ressalte-se que a cessão prévia de créditos futuros é um dos assuntos que têm gerado mais polêmica na doutrina em razão das sérias consequiências causadas ao devedorfiduciante, que acaba tendo todo o seu fluxo de caixa futuro comprometido com as instituições financeiras, o que pode, sem dúvida, inviabilizar a sua efetiva possibilidade de recuperação.

\subsection{Análise Crítica da Solução Adotada pelo Legislador em Face dos Princípios da Lei de Recuperação de Empresas}

A prática bancária e falimentar vem demonstrando a fragilidade da cessão fiduciária de créditos e títulos de crédito e a falta de segurança jurídica do referido instituto. Embora a cessão fiduciária de crédito tenha sido admitida pela Lei de Mercado de Capitais (com as alterações introduzidas pela Lei $\left.n^{0} 10.931 / 2004\right)$, não nos parece ter havido regulamentação adequada desse instituto.

Não houve preocupação por parte do legislador em conceituar a cessão fiduciária de crédito, em traçar as bases do instituto, em delinear as hipóteses em que tal cessão poderia ser utilizada, em limitar a cessão de créditos futuros, em expressamente admitir a constituição de um patrimônio de afetação dos créditos cedidos fiduciariamente para uma finalidade específica e devidamente caracterizada nos contratos bancários.

Importante mencionar que vários países da América Latina, tais como: Panamá, Argentina, México, Chile, Colômbia, dentre outros, adotaram a figura do fideicomisso financeiro, que possui função semelhante à da cessão fiduciária. Podemos afirmar que tanto no México como na Argentina o fideicomisso financeiro foi extremamente bem regulamentado e o legislador adotou o instituto do patrimônio de afetação para os bens e direitos que compõem o fideicomisso financeiro. A adoção de um patrimônio de afetação 
faz com que os bens fideicomitidos sejam afetados para o cumprimento da finalidade para o qual foi constituído o fideicomisso, não se sujeitando aos efeitos da falência nem do devedor nem do credor. Em razão de possuir uma legislação apropriada, o instituto do fideicomisso financeiro vem sendo largamente utilizado pelas instituições financeiras como garantia de empréstimos, não havendo dúvida sobre o tratamento dos bens fideicomitidos nas hipóteses de insolvência do devedor fiduciante.

No Brasil, a grande celeuma diz respeito ao tratamento a ser dado aos créditos cedidos fiduciariamente nas hipóteses de recuperação judicial e falência do devedor fiduciante, havendo divergência da doutrina e da jurisprudência. Este tema ainda não chegou ao Superior Tribunal de Justiça, que deverá pacificar a questão.

Se prevalecer o entendimento da doutrina e jurisprudência de que os créditos cedidos fiduciariamente estariam sujeitos à recuperação judicial dos devedores-fiduciantes, surge a questão de saber se ele seria classificado como quirografário ou crédito com garantia real. Na hipótese de classificação do referido crédito como quirografário, a consequiência seria a restrição ao crédito por parte das instituições financeiras e a volta da utilização do penhor de direitos creditórios como garantia das operações financeiras. A restrição de crédito, por sua vez, impossibilita a ampliação e até a manutenção das atividades das empresas, especialmente para aquelas que estão em situação de crise.

Por outro lado, se prevalecer o entendimento da doutrina e jurisprudência de que os créditos cedidos fiduciariamente não estariam sujeitos à recuperação judicial do devedorfiduciante, surge a questão de saber se há a real possibilidade de recuperação de empresas que tenham como maiores credores bancos que detenham créditos cedidos fiduciariamente como garantia de suas operações financeiras.

Se a maior parte dos recebíveis da empresa estiver comprometida com os bancos e se, no dia seguinte ao pedido de recuperação judicial por parte da empresa em crise, os bancos tomarem para si tais créditos, então não há que se falar em possibilidade de recuperação da empresa, já que é bem provável que a empresa não tenha fundos suficientes para pagar os demais credores e para continuar com suas atividades. Este fato gera o encerramento das atividades da referida empresa, com a demissão em massa de 
empregados, o não pagamento de seus salários, o não pagamento de fornecedores que, muitas vezes, podem ter um grande grau de dependência com a empresa em recuperação. Vê-se, portanto, um efeito em cascata, que pode gerar sérias consequiências econômicas ao mercado local onde a empresa em crise está situada.

Portanto, resta claro que a exclusão dos credores garantidos por cessão fiduciária de créditos e/ou títulos de crédito dos efeitos da recuperação judicial do devedor não se coaduna com os princípios da recuperação judicial elencados no artigo 47 da LRE, qual seja, a viabilização da superação da crise econômico-financeira do devedor, a fim de permitir a manutenção da fonte produtora, do emprego dos trabalhadores e dos interesses dos credores, promovendo, assim, a preservação da empresa, sua função social e o estímulo à atividade econômica.

Pretende-se com a LRE priorizar a recuperação sobre a liquidação, frisando-se que a preservação da empresa não significa a preservação do empresário ou dos administradores da sociedade empresária. Proteger a atividade produtiva implica, quase sempre, apartar os reais interesses envolvidos na empresa dos interesses de seus mentores. A separação entre a sorte da empresa e a de seus titulares apresenta-se, às vezes, como o caminho mais proveitoso no sentido de uma solução justa e eficaz para a conjuntura jurídico-econômica da insolvência. Se é verdade que a proteção do crédito mantenedor da regularidade do mercado é um intento que precisa ser perseguido, não é menos verdade que o interesse sócioeconômico de resguardar a empresa, como unidade de produção de bens e/ou serviços, prevalece sobre quaisquer outros afetados pelo estado deficitário, porque se revela como instrumento mais adequado para atender aos interesses dos credores, dos empregados e do mercado. ${ }^{339}$

Como bem observa Manoel Justino, a recuperação judicial destina-se às empresas que estejam em situação de crise econômico-financeira, com possibilidade, porém, de superação. Tal tentativa de recuperação prende-se ao valor social da empresa em funcionamento, que deve ser preservado não só pelo incremento da produção, como, principalmente, pela manutenção do emprego, elemento da paz social. Por isso mesmo, a Lei, não por acaso, estabelece uma ordem de prioridade nas finalidades que diz perseguir,

${ }^{339}$ Waldo Fazzio Junior, Nova Lei de Falência e Recuperação de Empresas, $3^{\mathrm{a}}$ ed., p. 36 
colocando como primeiro objetivo "a manutenção da fonte produtora", ou seja, a manutenção da atividade empresarial em sua plenitude tanto quanto possível, com o que haverá a possiblidade de manter também o "emprego dos trabalhadores". Mantida a atividade empresarial e o trabalho dos empregados, será possível então satisfazer os "interesses dos credores". 340

Vera Helena de Mello Franco e Rachel Sztajn observam que sanear a crise econômico-financeira do empresário ou da sociedade empresária, pressuposto extrajurídico, matéria de fato, que varia de caso para caso, significa equacionar o evento que gera dificuldades para a manutenção da atividade tal como originalmente organizada a fim de preservar os negócios sociais, a manutenção dos empregos e, igualmente, satisfazer os direitos e interesses dos credores. Em que pese a função social que se diz presente na nova lei e a ênfase que se lhe dá no artigo 47 da LRE, ao contrário do que ocorre no direito francês, no italiano e, inclusive, no português, o Estado não intervem para alavancar essa recuperação, recaindo exclusivamente sobre os ombros dos particulares, basicamente dos credores. $^{341}$

Para um efetivo saneamento da crise econômico-financeira da empresa em crise, necessário que haja concessão de crédito (o chamado dinheiro novo ou dip finance) à empresa em crise durante o período da recuperação judicial.

Também há necessidade da efetiva participação das instituições financeiras no processo de recuperação, em razão de sua importância em relação à concessão de crédito. É verdade que, na prática atual, as instituições financeiras acabam por envolver-se no procedimento de recuperação judicial, muito embora conseguir um acordo com todas elas vem sendo tarefa árdua para os militantes da área, especialmente para os que advogam para as empresas em recuperação.

$\mathrm{Na}$ tentativa de melhorar o tratamento da cessão fiduciária na LRE, o Deputado Carlos Bezerra apresentou em 03.02.2009 o Projeto de Lei n. ${ }^{\circ} 4.568$ (que foi apensado ao PL n. ${ }^{0}$ 7.604/2006), que propõe a inclusão dos créditos garantidos por cessão fiduciária de

\footnotetext{
${ }^{340}$ Lei de Recuperação de Empresas e Falência Comentada: Lei 11.101/2005 comentário artigo por artigo, $5^{\mathrm{a}}$ ed., p. 142.

${ }^{341}$ Falência e Recuperação de Empresa em Crise, p. 234.
} 
títulos de crédito, ainda que não vencidos, aos efeitos da recuperação judicial do devedor. No entanto, o referido PL não menciona em que classe tais créditos deveriam ser incluídos. Não nos parece que a solução proposta seja a mais adequada para a solução dos problemas envolvendo a cessão fiduciária de créditos e/ou títulos de crédito.

Parece-nos que uma solução intermediária deveria ser proposta, para não prejudicar as instituições financeiras, sem as quais não há processo de recuperação judicial, já que são elas as responsáveis pela concessão de crédito, mas também para permitir a real e efetiva possibilidade de recuperação da empresa em crise.

Pensamos que a solução intermediária poderia ser a modificação de algumas regras da recuperação extrajudicial, para permitir que credores titulares de créditos excluídos dos efeitos da recuperação judicial, nos termos dos parágrafos $3^{\circ}$ e $4^{\circ}$ do artigo 49 da LRE, participem da recuperação extrajudicial, reconhecendo, desta forma, a importância de tais créditos para o atendimento das finalidades de preservação da empresa em crise.

Nossa proposta é a de que o pedido de homologação do plano de recuperação extrajudicial acarrete, também, a suspensão de direitos, ações ou execuções e a impossibilidade do pedido de decretação de falência pelos credores sujeitos ao plano de recuperação extrajudicial a partir de seu ajuizamento. Pensamos, também, que deveria haver alteração do quórum de aprovação do plano de recuperação extrajudicial de $3 / 5$ pelo da maioria dos credores, de modo a impedir que as minorias dissidentes inviabilizem a recuperação extrajudicial.

Por fim, acreditamos que deveria haver alteração da redação do parágrafo $3^{\circ}$ do artigo 49 da LRE para expressamente incluir o "titular de direitos sobre bens móveis e sobre títulos de crédito" como sujeito excluído dos efeitos da recuperação judicial do devedor, de maneira a refletir o entendimento que, atualmente, é majoritário tanto da doutrina como da jurisprudência, evitando-se debates acerca do conceito de "proprietário fiduciário". 
Cremos que somente uma solução que não privilegie tanto os interesses de uma só parte (seja credor ou o devedor), mas que privilegie a economia como um todo, seja a mais adequada ao atendimentos das finalidades propostas pela LRE.

\subsection{Posição da Doutrina e Jurisprudência sobre o Tratamento da Cessão Fiduciária na Falência do Devedor-Fiduciante}

Como já dissemos no decorrer do presente trabalho, pela cessão fiduciária há a transferência plena e efetiva da titularidade dos créditos ao credor-fiduciário até final liquidação da dívida pelo devedor. Os créditos detidos pelo credor fiduciário, ao nosso ver, não estão sujeitos aos efeitos da recuperação judicial, como já amplamente discutido no item 4.3 deste trabalho, e tampouco estão sujeitos aos efeitos da falência do devedorfiduciante, pois o credor-fiduciário é titular dos referidos créditos.

Nossa opinião é reforçada pelo disposto no artigo 20 da LSFI que concede ao credor-fiduciário o direito de pedir restituição dos títulos de crédito representativos dos créditos cedidos fiduciaramente que ainda estiverem em posse do devedor, na hipótese de falência do devedor-cedente. A restituição deverá ser feita na forma da LRE.

Dúvida reside em como compatibilizar o disposto no inciso II do artigo 1.425 do CC, que prevê o vencimento antecipado da dívida se o devedor cair em insolvência ou falir, em face do disposto no artigo 118 da LRE, que permite ao administrador judicial, mediante autorização do Comitê, dar cumprimento a contrato unilateral se esse fato reduzir ou evitar o aumento do passivo da massa falida ou for necessário à manutenção e preservação de seus ativos, realizando o pagamento da prestação pela qual está obrigada. ${ }^{342}$

\footnotetext{
${ }^{342}$ Importante mencionar que a cessão fiduciária de crédito é normalmente celebrada para garantir um empréstimo contraído pelo devedor-cedente com a instituição financeira. O contrato de mútuo é considerado pela doutrina como contrato unilateral (Cfr. Washington de Barros Monteiro, Curso de Direito Civil, v. 5, p. 23 e 218; Caio Mario da Silva Pereira, Instituições de Direito Civil, v. III, 12a ed., p. 68.) Sendo a cessão fiduciária de crédito acessória ao contrato de mútuo, entendemos serem aplicáveis as regras sobre contrato unilateral previstas no artigo 118 da LRE na hipótese de falência do devedor.
} 
Importante observar que a regra contida no artigo 118 da LRE é nova e foi inserida para evitar as divergências doutrinárias existentes sob a égide do Decreto-lei $\mathrm{n}^{\mathbf{o}}$ $7.661 / 1945$, pois naquela época não havia um tratamento dos contratos unilaterais na hipótese de falência do devedor. Alguns doutrinadores defendiam o vencimento imediato das dívidas, sob o argumento de que as dívidas garantidas pela propriedade fiduciária resultavam, na maioria dos casos, de um contrato de mútuo que, por sua natureza, é contrato unilateral. O vencimento da dívida também acarretava o vencimento da propriedade fiduciária. Nesse sentido, Orlando Gomes ${ }^{343}$, José Carlos Moreira Alves ${ }^{344}$, Joaquim Antonio Penalva Santos ${ }^{345}$, Nelson Abrão ${ }^{346}$, José da Silva Pacheco ${ }^{347}$.

De outro lado, Paulo Restiffe Neto ${ }^{348}$ e Milton Paulo de Carvalho ${ }^{349}$ defendiam a aplicabilidade do artigo 43 do Decreto-lei no 7.661/1945 (atual artigo 117 da LRE), sob o argumento de que a falência não seria causa convencional de vencimento antecipado da dívida.

Ricardo Tepedino observa que a aplicação prática da regra prevista no artigo 118 da LRE parece se restringir à hipótese em que o falido é mutuário e a dívida conta com alienação fiduciária em garantia, pois nesse caso o descumprimento dará ao credor fiduciário direito a requerer a restituição do bem e, dependendo do saldo pendente, poderá ser muito mais vantajoso quitar a dívida, entrando o bem fiduciariamente alienado para a massa. Observa o referido autor que não obstante a falta de previsão expressa nesse sentido, a interpretação sistemática da norma indica que a parte não falida, se quiser deduzir alguma pretensão fundada no descumprimento da obrigação ajustada em contrato unilateral, deve interpelar previamente o administrador para indagar sobre o cumprimento, nos mesmos termos estatuídos pelo artigo $117 .{ }^{350}$ Embora o comentário de Ricardo Tepedino tenha sido feito com base na alienação fiduciária, entendemos ser plenamente aplicável à cessão fiduciária.

\footnotetext{
343 Alienação Fiduciária em Garantia, p. 144.

${ }^{344}$ Da Alienação Fiduciária em Garantia, p. 188 (inclusive nota de rodapé 315).

${ }^{345}$ Obrigações e Contratos na Falência, p. 24.

${ }^{346}$ Curso de Direito Falimentar, p. 71.

347 Processo de Falência e Concordata, p. 317.

${ }^{348}$ Garantia Fiduciária, pp. 211 e 212.

${ }^{349}$ Da Proteção Processual da Alienação Fiduciária em Garantia. In: Revista dos Tribunais, São Paulo, v. 410, ano 58, 1969, p. 39.

${ }^{350}$ In:, Paulo F. C. Salles de Toledo (Coord.); e Carlos Henrique Abrão (Coord.); Comentários à Lei de Recuperação de Empresas e Falências, p. 314.
} 
Feitas as considerações sobre os efeitos do contrato de mútuo garantido por cessão fiduciária na hipótese de falência do devedor-fiduciante, passaremos a comentar o procedimento para a restituição dos títulos de crédito que não tiverem sido transferidos ao credor-fiduciário.

Decretada a falência do devedor-fiduciante, caberá ao administrador judicial arrecadar todos os bens que estiverem na posse do devedor e isso poderá incluir bens de terceiros. Como bem observa Rubens Requião, o desapossamento do falido é consequiência da separação do patrimônio falimentar. ${ }^{351}$

O artigo 85 da LRE dispõe acerca do pedido de restituição nos seguintes termos:

“Art. 85. O proprietário de bem arrecadado no processo de falência ou que se encontre em poder do devedor na data da decretação da falência poderá pedir sua restituição. Parágrafo único. Também pode ser pedida a restituição de coisa vendida a crédito e entregue ao devedor nos 15 (quinze) dias anteriores ao requerimento de sua falência, se ainda não alienada.(grifo nosso)"

Como bem observa Marcus Elidius Michelli de Almeida, diferentemente da redação do artigo 76 do Decreto-lei $n^{\circ} 7.661 / 1945$, que permitia o pedido de restituição quando se estivesse diante de um bem devido em razão de contrato, o atual texto da LRE reduz a uma única hipótese a restituição, qual seja, ser proprietário do bem. Neste caso, deve-se interpretar propriedade de forma mais ampla, uma vez que a lei não fez nenhum restrição. $^{352}$

Manoel Justino observa que no sistema da Lei atual, embora seja prevista a restituição de outros bens, além daqueles devidos em razão do direito de propriedade, estas outras restituições estão previstas em outros artigos da legislação, como por exemplo no artigo 85 e no artigo 136, ou em legislação especial, como é o caso da alienação fiduciária. $^{353}$

\footnotetext{
${ }^{351}$ Curso de Direito Falimentar, v. 1, 17 ed., p. 180.

352 In: Luiz Fernando Valente de Paiva (Coord.). Direito Falimentar e a Nova Lei de Falências e Recuperação de Empresas: Lei 11.101 de 9 de Fevereiro de 2005 e LC 118 de 9 de Fevereiro de 2005, p. 308.

${ }^{353}$ Lei de Recuperação de Empresas e Falências Comentada: Lei 11.101/ 2005 - comentário artigo por artigo, p. 230.
} 
O pedido de restituição deverá ser feito por meio de petição fundamentada e dirigida ao juiz da falência, descrevendo a coisa reclamada que, no caso da cessão fiduciária, será os títulos de crédito que estiverem na posse do devedor. O juiz mandará autuar em separado o requerimento com os documentos que o instruírem e determinará a intimação do falido, do Comitê, dos credores e do administrador judicial para que, no prazo sucessivo de 5 (cinco) dias, se manifestem, valendo como contestação a manifestação contrária à restituição. Contestado o pedido e deferidas as provas porventura requeridas, o juiz designará audiência de instrução e julgamento, se necessária. Não havendo provas a realizar, os autos serão conclusos para sentença.

A sentença que reconhecer o direito do requerente determinará a entrega da coisa no prazo de 48 (quarenta e oito) horas. A sentença que negar a restituição, quando for o caso, incluirá o requerente no quadro-geral de credores, na classificação que lhe couber, na forma da LRE. Da sentença que julgar o pedido de restituição caberá apelação sem efeito suspensivo. $\mathrm{O}$ autor do pedido de restituição que pretender receber o bem ou a quantia reclamada antes do trânsito em julgado da sentença prestará caução. O pedido de restituição suspende a disponibilidade da coisa até o trânsito em julgado. 


\section{CONCLUSÃO}

No presente trabalho analisamos o instituto da cessão fiduciária de créditos e/ou títulos de créditos regulado no artigo 66-B da Lei de Mercado de Capitais, com vistas a identificar o seu tratamento nas hipóteses de recuperação judicial e/ou falência do devedorfiduciante.

Partimos do conceito da fiducia cum creditore do direito romano e fizemos um comparativo entre ela e o penhor do direito germânico e o trust do direito anglo-saxão. Também analisamos o fideicomisso da América Latina e pudemos verificar que, ao contrário da experiência brasileira, o fideicomisso financeiro com fins de garantia foi bem regulamentado pela Argentina e México, prevendo a constituição de um patrimônio separado para os bens que o compõem. Esta solução nos parece adequada, pois confere ao fiduciante e fiduciário maior segurança jurídica na hipótese de insolvência de qualquer das partes, já que o bem permanece segregado, não integrando a massa falida do devedor, podendo ser utilizado somente para os fins de garantia a que se destinam.

Depois, analisamos a estrutura do negócio fiduciário que caracteriza-se pela transferência plena e efetiva da propriedade de uma coisa e/ou titularidade de um bem ao fiduciante, objetivando garantir uma obrigação assumida entre devedor-fiduciante e credorfiduciário. Após o cumprimento da obrigação pelo devedor-fiduciante, o credor-fiduciário obriga-se a restituir a coisa e/ou o bem ao devedor-fiduciante.

Diferentemente do negócio simulado, no negócio fiduciário as partes desejam produzir um determinado resultado, ainda que se utilizem de um meio mais forte para conseguir um resultado mais fraco (ex.: compra e venda com fins de garantia). Esta incongruência entre meio e fim é uma das principais características do negócio fiduciário.

Com relação às espécies de negócios fiduciários no Brasil, mencionamos a tentativa de incluir-se a fidúcia em nosso ordenamento jurídico no Projeto de Código de Obrigações de 1965, de relatoria de Caio Mario da Silva Pereira. 
Embora o Projeto não tenha prosperado, houve paulatinamente a introdução em nosso ordenamento jurídico de leis esparsas admitindo certas modalidades de negócios fiduciários, tais como: (i) a alienação fiduciária em garantia de bens móveis que está regulada no artigo 66-B da Lei de Mercado de Capitais, com a redação dada pela Lei ${ }^{\circ}$ 10.931, de 02.08.2004; (ii) a alienação fiduciária em garantia de bens imóveis introduzida pela LSFI; (iii) a alienação fiduciária de ações, partes beneficiárias e bônus de subscrição, prevista no artigo 40 da Lei das Sociedades por Ações; (iv) a cessão fiduciária de direitos sobre coisas móveis, bem como de títulos de crédito introduzida no artigo 66-B da Lei de Mercado de Capitais, com a redação dada pela Lei $n^{\circ} 10.931$, de 02.08.2004; dentre outras. Por fim, importante mencionar que o Código Civil de 2002 inseriu a propriedade fiduciária nos artigos 1.361 a 1.368 na parte relativa ao Direito das Coisas.

Feitas as considerações acerca da estrutura do negócio fiduciário e suas principais espécies, passamos a tratar especificamente da cessão fiduciária de direitos sobre bens móveis e sobre títulos de crédito prevista no artigo 66-B da Lei de Mercado de Capitais, partindo de uma análise das principais características da cessão ordinária para, então, analisar especificamente as características da cessão fiduciária de créditos e/ou títulos de crédito.

Diferentemente do penhor em que há a constituição de garantia real sobre coisa alheia, na cessão fiduciária de créditos e/ou títulos de crédito em garantia há a efetiva transferência do crédito para o cessionário-fiduciário, que deterá a titularidade plena do referido crédito, devendo retransmiti-lo ao devedor tão logo ele cumpra a obrigação contida no negócio subjacente. No caso de inadimplemento do devedor-fiduciante, o credor-fiduciário poderá utilizar as importâncias recebidas referentes aos créditos cedidos para abater a dívida e os encargos incorridos pelo credor-fiduciário para a cobrança do crédito, restituindo eventual saldo credor ao devedor-fiduciante.

O mecanismo auto-satisfativo da cessão fiduciária de créditos e/ou títulos de crédito aliado ao fato de a maior parte da doutrina e jurisprudência admitir que a cessão fiduciária está fora dos efeitos da recuperação judicial do devedor, fez com que esta garantia passa-se a ser largamente utilizada pelas instituições financeiras em substituição ao penhor de direitos creditórios. 
Todavia, ainda há um grande debate na doutrina e jurisprudência sobre o tratamento a ser dado à cessão fiduciária de créditos e/ou títulos de crédito na hipótese de recuperação judicial do devedor-fiduciante.

Isto porque, o parágrafo $3^{\circ}$ do artigo 49 da LRE exclui dos efeitos da recuperação judicial os "proprietários fiduciários de bens móveis e imóveis". A maior parte da doutrina e da jurisprudência defende que os titulares de créditos cedidos fiduciariamente estão compreendidos na definição de "proprietário fiduciário de bem móvel" prevista no referido parágrafo $3^{\circ}$ do artigo 49 da LRE e, portanto, estão excluídos dos efeitos da recuperação judicial do devedor-fiduciante.

Somos partidários desta corrente, pois da análise do processo legislativo da LRE no tocante ao parágrafo $3^{\circ}$ do artigo 49 , nos pareceu que o legislador, usando o título errôneo de "alienação fiduciária de direitos", teve a intenção de excluir os créditos cedidos fiduciariamente dos efeitos da recuperação judicial do devedor.

Sob o ponto de vista jurídico, acreditamos que no conceito de "proprietário fiduciário de bens móveis" previsto no parágrafo $3^{\circ}$ do artigo 49 da LRE estão também incluídos os credores titulares de créditos e/ou títulos de créditos cedidos fiduciariamente, pelas seguintes razões: (i) primeiro, porque há consenso na doutrina de que tanto créditos como títulos de créditos são bens móveis, por força do disposto no artigo 83, inciso III do CC; e (ii) depois, porque a cessão fiduciária de créditos e/ou títulos de crédito é modalidade de negócio fiduciário, onde há a efetiva transferência da titularidade dos referidos créditos para o cessionário, que o torna verdadeiro proprietário.

Por outro lado, parte minoritária da doutrina e da jurisprudência defende que o parágrafo $3^{\circ}$ do artigo 49 da LRE não menciona expressamente "os titulares de crédito cedidos fiduciariamente" e, sendo o referido parágrafo exceção à regra de que todos os credores estão sujeitos à recuperação judicial do devedor, sua redação deveria ser interpretada restritivamente, razão pela qual os credores titulares de créditos cedidos fiduciariamente estão sujeitos à recuperação judicial do devedor-fiduciante. 
A divergência da doutrina e da jurisprudência sobre o tema acaba por acarretar insegurança jurídica quanto ao uso da cessão fiduciária como forma de garantia. De um lado, as instituições financeiras têm dúvidas sobre a real segurança de tal garantia, o que pode comprometer uma eficiente avaliação de risco de crédito, assim como a recuperação do crédito na hipótese de insolvência do devedor. Por outro lado, as empresas em crise têm dúvidas sobre a viabilidade de sua efetiva recuperação, principalmente quando seus maiores credores forem bancos.

Por todos esses motivos, entendemos ser de suma importância que haja um tratamento adequado do instituto da cessão fiduciária de créditos e/ou títulos de crédito na LRE. Para tanto, propomos a modificação do parágrafo $3^{\circ}$ do artigo 49 da LRE para fazer constar expressamente que os titulares de créditos cedidos fiduciariamente estão excluídos dos efeitos da recuperação judicial do devedor-fiduciante.

Parece-nos, também, que uma solução legislativa intermediária deveria ser proposta, como a possibilidade de que os créditos não sujeitos à recuperação judicial possam ser objeto de recuperação extrajudicial.

Cremos que somente uma solução que não privilegie tanto os interesses de uma só parte (seja credor ou o devedor), mas que privilegie a economia como um todo, seja a mais adequada ao atendimento do princípio da preservação da empresa em crise trazido pela LRE. 


\section{BIBLIOGRAFIA}

ABRÃO, Nelson. Curso de Direito Falimentar. São Paulo: Saraiva, 1978.

ALSTER, Maria Izolina Schaurich. A Cessão de Crédito: Natureza Jurídica. In: Revista dos Tribunais, v. 682, ano 81, ago de 1992, pp. 39-49.

ALVES, José Carlos Moreira. Da Alienação Fiduciária em Garantia. Rio de Janeiro: Forense, 1987.

. Da Fidúcia Romana à Alienação Fiduciária em Garantia no

Direito Brasileiro, p.23-45. In: CAHALI, Youssef Said (Coord.). Contratos Nominados: Doutrina e Jurisprudência. São Paulo: Saraiva, 1995.

ASCARELLI, Tullio. Negocio Juridico Indirecto. Lisboa: Jornal do Foro, 1965.

. Problemas das Sociedades Anônimas e Direito Comparado. $2^{\mathrm{a}}$ ed. São Paulo: Saraiva, 1969.

. Teoria Geral dos Títulos de Crédito. Tradução de Nicolau Nazu. São Paulo: Saraiva, 1943.

ASQUINI, Alberto. Titoli di Credito e in Particolare Cambiale e Titoli Bancari di Pagamento: Lezioni Di Diritto Commerciale. Padova: Cedam, 1951.

AZEVEDO, Álvaro Villaça. Contratos Inominados ou Atípicos e Negocio Fiduciário. $3^{\text {a }}$ ed. Belém: Cejup, 1988.

Prisão Civil por Dívida. São Paulo: Revista dos Tribunais, 1993.

Alienação Fiduciária em Garantia de Bem Móvel e Imóvel. In:

Revista da Faculdade de Direito da Faculdade Armando Álvares Penteado. São Paulo, 2002, ano $1, n^{\circ} .1$, pp. 61-84. 
AZEVEDO, Antônio Junqueira. Negócio jurídico - Existência, Validade e Eficácia. São Paulo: Saraiva, 2002.

BARBERO, Domenico. Sistema Istituzionale del Diritto Privato Italiano, v. II, $2^{a}$ Ed. Turim: Unione Tipográfico - Editrice Torinese, 1949.

BARRETO FILHO, Oscar. Teoria do Estabelecimento Comercial: Fundo de Comércio ou Fazenda Mercantil. $2^{a}$ ed. São Paulo: Saraiva, 1988.

BEVILÁQUA, Clóvis. Theoria Geral do Direito Civil. $2^{\mathrm{a}}$ ed. Rio de Janeiro: Francisco Alves, 1929.

BEZERRA FILHO, Manoel Justino. Lei de Recuperação de Empresas e Falências Comentada: Lei 11.101/ 2005 - comentário artigo por artigo. 5a ed. São Paulo: Revista dos Tribunais, 2008.

BIONDI, Biondo. Corso di Instituzioni di Diritto Romano. Catania: Siciliana Tipografica, 1929.

Istituzioni di Diritto Romano. Milano: Giuffrè, 1946.

BONAMIM, Alexandre. O Credor Fiduciário e a Recuperação Judicial. Artigo publicado no Jornal Valor Econômico de 17.12.2008.

BONFANTE, Pietro. Istituzioni di Diritto Romano. 10ª ed. Turim: G. Giappicheli, 1949.

BORGES, João Eunápio. Títulos de Crédito. Rio de Janeiro: Forense, 1983.

BULGARELLI, Waldirio. Títulos de Crédito. 12a ed. São Paulo: Atlas, 1996.

BUZAID, Alfredo. Ensaio sobre a Alienação Fiduciária em Garantia. Revista dos Tribunais, v. 401, março de 1969, pp. 9-29. 
CAMINHA, Uinie. Securitização. São Paulo: Saraiva, 2007.

CAMPINHO, Sergio. Falência e Recuperação de Empresa. $4^{\mathrm{a}}$ ed. São Paulo: Renovar, 2009.

CASTRO Y BRAVO, Federico de. El negocio jurídico. Madrid: Instituto Nacional de Estudios Jurídicos, 1967.

CARIOTA-FERRARA, Luigi. I Negozi Fiduciari: Trasferimento Cessione e Girata a Scopo di Mandato e di Garanzia. Pádua: Cedam, 1933.

CARVALHO, Milton Paulo de. Da proteção processual da alienação fiduciária em garantia. In: Revista dos Tribunais, v. 410, ano 58 - 1969, pp. 32-41.

CARVALHO, Orlando de. Negócio Jurídico Indireto. In: Boletim da Faculdade de Direito de Coimbra, suplemento X/1, 1952.

CHALHUB, Melhim Namem. Negócio Fiduciário. 4ª ed. São Paulo: Renovar, 2009.

. Curso de Direito Civil: Direitos Reais. São Paulo: Forense,

2004.

. Trust: Perspectivas do Direito Comparado na Transmissão

da Propriedade para Administração de Investimentos e Garantia. Rio de Janeiro:

Renovar, 2001

Propriedade Fiduciária de Bens Móveis em Garantia. In:

Revista de Direito Bancário e do Mercado de Capitais, Ano 6, no 21, jul-set 2003, p. 302 a 335.

A Cessão Fiduciária e a Recuperação Judicial. Artigo publicado no Jornal Valor Econômico de 24.07.2009. 
COELHO, Fábio Ulhoa. Comentários à Nova Lei de Falências e de Recuperação de Empresas. $7^{\mathrm{a}}$ ed. São Paulo: Saraiva, 2010.

CORREIA, Alexandre e SCIASCIA, Gaetano. Manual de Direito Romano: e textos em correspondência com os artigos do código civil brasileiro. $4^{\mathrm{a}}$ ed. São Paulo: Saraiva, 1961.

COUTO E SILVA, Clóvis do. Cessão de Crédito. In: Revista dos Tribunais, v. 638, ano 77 - Dezembro de 1988, p. 10-14.

COVIELLO, Nicola. Manuale di Diritto Civile Italiano, v. 1. Milano: Socièta editrice libraria, 1924.

CUNHA, Paulo A. V. Do património: Estudo de direito privado. Lisboa: Minerva, 1934.

DINIZ, Maria Helena. Dicionário Jurídico, v. 1, 3 e 4. São Paulo: Saraiva, 1998.

DOMINEDÒ, Francesco M. La Costituzione Fitizzia Delle Anonime. In: Studi di diritto commerciale in onore di Vivante. Roma, 1932, II.

ENNECERUS, Ludwig e NIPPERDEY, Hans. Tratado de Derecho Civil de Ennecerus, Kipp e Wolff. Tomo I, v. II. 2a ${ }^{\text {a }}$ Parte. 3 ed. espanhola. Barcelona: Bosch Casa Editorial, 1956.

ESPARZA, Gustavo Américo. El fideicomiso: introducción a un estúdio comparado de su legislación en Argentina, México y Panamá. Buenos Aires: Gowa Ediciones Professionales, 2006.

ESTEVAM, Lincoln Fernando Pelizzon. Trava Bancária e Recuperação de Empresas. Artigo publicado no Jornal Valor Econômico de 23.09.2008. 
FABIAN, Christoph. Fidúcia: negócios fiduciários e relações externas. Porto Alegre: Sergio Antônio Fabris, 2007

FAZZIO JÚNIOR, Waldo. Nova Lei de Falência e Recuperação de Empresas. $3^{\mathrm{a}}$ ed. São Paulo: Atlas, 2006.

FELICIANO, Guilherme Guimarães. Tratado de Alienação Fiduciária em Garantia: Das Bases Romanas à Lei n. 9.514/97. São Paulo: LTR, 1999.

FERNANDES, Jean Carlos. Cessão Fiduciária de Títulos de Crédito: a Posição do Credor Fiduciário na Recuperção Judicial da Empresa. Rio de Janeiro: Lumen Juris, 2009.

FERRARA, Francesco. A simulação dos negócios jurídicos. Tradução de A. Bossa. São Paulo: Saraiva, 1939.

FERREIRA, Aurélio Buarque de Holanda. Novo Dicionário da Língua Portuguesa. Rio de Janeiro: Nova Fronteira, 1986.

FIUZA, César. Alienação fiduciária em garantia: de acordo com a Lei $n^{\circ}$ 9.514/97. Rio de Janeiro: AIDE Ed., 2000.

FRANCO, Vera Helena de Mello; e SZTAJN, Raquel. Falência e Recuperação de Empresa em Crise. Rio de Janeiro: Elsevier, 2008.

FREITAS, Augusto Teixeira de. Esboço do Código Civil, 2 v. Brasília: Ministério da Justiça, Fundação Universidade de Brasília, 1983.

GIERKE, Otto Friedrich von. Deutsches Privatrecht, v. 3. Leipzig: Duncker \& Humblot, 1895.

GIRALDI, Pedro Maria. Fideicomiso, ley 24.441. Buenos Aires: Depalma, 1998.

GOMES, Orlando. A Reforma do Código Civil. Salvador: Universidade da Bahia, 1965. 
Alienação fiduciária em garantia. $4^{\mathrm{a}}$ ed. São Paulo: Revista dos Tribunais, 1975. . Introdução ao Direito Civil, $11^{\mathrm{a}}$ Edição. Rio de Janeiro: Forense, 1995. Obrigações. Rio de Janeiro: Forense, 11ª ed. 1996. . Contrato de fidúcia ("trust”). In: Revista Forense, Rio de Janeiro, v. 211, ano 62, jul/set 1965, pp. 11-20.

GRASSETTI, Cesare. Donazione Fiduciaria. Milão, 1936.

GRAZIANI, Alessandro. Negozi Indiretti e Negozi Fiduciari. In: Revista de Diritto commerciale, 1933.

HANBURY, Harold Greville. Modern equity. Londres: Stevens \& Sons, 1943.

HEDEMANN, J.W. Derechos Reales, v. II, traduzido do espanhol por Jose Luiz Diez Pastor e Manuel Gonzalez Enriquez, Madri: Revista de Derecho Privado, 1955.

HOUAISS Antônio; VILLAR, Mauro de Salles; e MELLO FRANCO, Francisco Manoel de (editores). Dicionário Houaiss da Língua Portuguesa. Rio de Janeiro: Objetiva, 2001.

JABUR, Gilberto Haddad (Coord.); PEREIRA JR., Antonio Jorge (Coord.). Direito dos Contratos II. São Paulo: Quartier Latin, 2008.

JACQUELIN, René. De la fiducie. Paris: A. Giard, 1891

KIPER, Claudio Marcelo; e LISOPRAWSKI, Silvio. Tratado de Fideicomiso. Buenos Aires: Depalma, 2004. 
LARENZ, Karl. Derecho civil: parte general e parte II, traduzido para o espanhol por Miguel Izquierdo y Macías-Picavea. Madrid: Editorial Revista de Derecho Privado, 1978.

LEITÃO, Luís Manuel Teles de Menezes. Cessão de Créditos. Coimbra: Almedina, 2005.

LEONARDO, Rodrigo Xavier. A cessão de créditos: reflexões sobre a causalidade na transmissão de bens no direito brasileiro. In: JABUR, Gilberto Haddad (Coord.); PEREIRA JR., Antonio Jorge (Coord.). Direito dos Contratos II. São Paulo: Quartier Latin, 2008, p. 338-364.

LIMA, Otto de Souza; Negócio Fiduciário. São Paulo: Revista de Tribunais, 1962.

LIMA, Otto de Souza; Negócio Fiduciário. Tese para concurso a cátedra de Direito Civil, da Faculdade de Direito da Universidade de São Paulo, 1959.

LIPARI, Nicolo. Il Negozi fiduciari. Milano: Dott. A Giuffrè, 1971.

LONGO, Carlo. Corso di Diritto Romano: La Fiducia. Milano: A. Giuffrè, 1933

LOPES, Miguel Maria de Serpa. Curso de Direito Civil, v. II. $5^{\text {a }}$ ed. Rio de Janeiro: Freitas Bastos, 1989.

. Curso de Direito Civil, v. VI. $4^{\mathrm{a}}$ ed. Rio de Janeiro: Freitas

Bastos, 1996.

LUIZI, Fernando Fiorezzi de; e BACELAR, Luiz Gustavo. Alienação Fiduciária x Cessão Fiduciária. Artigo publicado no Jornal A Tribuna do Direito de novembro de 2008.

MAMEDE, Gladson. $O$ Cidadão $e$ Cédula. In: http://www.buscalegis.ufsc.br/revistas/index.php/buscalegis/article/viewFile/5000/456 9. 
MARINO, Francisco Paulo de Crescenzo. Notas sobre o negócio jurídico fiduciário. In: Revista Trimestral de Direito Civil, ano 5, vol. 20, out/dez 2004, p. 35-63.

MARKY, Thomas. Curso elementar de direito romano. São Paulo: Saraiva, 1995

MARTINS, Fran. Títulos de crédito, v. 1, 11ª ed. Rio de Janeiro: Forense, 1995.

MARTINS-COSTA, Judith. Negócios Fiduciários - considerações sobre a possibilidade de acolhimento do trust no Direito Brasileiro. In: Revista dos Tribunais, v. 657, p. 3750.

MARTÍNEZ, Jorge Alfredo Domínguez. Dos Aspectos de La Esencia Del Fideicomiso Mexicano. México: Editorial Porrúa, 2000.

MARTORELL, Mariano Navarro. La propriedad fiduciaria. Barcelona: Bosch, Casa Editorial, 1950.

MENDONÇA, Manuel Ignácio Carvalho de. Introducção Geral ao Direito das Cousas (dos direitos reais). Rio de Janeiro: Jacintho Ribeiro dos Santos, 1915.

MENDONÇA, José Xavier Carvalho de. Tratado de Direito Comercial Brasileiro, v. V, Livro III, Parte II, $7^{\text {a }}$ ed. São Paulo:Freitas Bastos, 1963.

MESSINA, Giuseppe. Scritti Giuridici, v. 1 - Negozi Fiduciari. Milano: Giuffre, 1948.

MESSINEO, Francesco. Il Contratto in Genere, Tomo Secondo. Milão: Dott. A. Giuffrè Editore, 1972.

MIRANDA, Custódio da Piedade Ubaldino. Negócio jurídico indireto e negócio fiduciário. In: Revista de Direito Civil, Imobiliário, Agrário e Empresarial, ano 8, julho/set 1984, p. 81-94. 
MM., Aubry et Rau. Cours de Droit Civil Français d'après la méthode de Zcharie, Tomo IX, $5^{\text {a }}$ Ed. Paris: Marchal ET Billard, 1917.

MONTEIRO, Washington de Barros. Curso de Direito Civil, v. 4, Direito das Obrigações $-1^{a}$ Parte, $27^{\mathrm{a}}$ ed. São Paulo: Saraiva, 1994.

Curso de Direito Civil, v. 5, Direito das Obrigações $-2^{a}$ Parte, $27^{\mathrm{a}}$ ed. São Paulo: Saraiva, 1994.

MUNHOZ, Eduardo Secchi. Cessão Fiduciária de Direitos de Crédito e a Recuperação Judicial da Empresa. In: Revista do Advogado n ${ }^{\circ}$ 105, ano XXIX, Setembro de 2009, p. 33-47.

NOGUEIRA, André Carvalho. Propriedade fiduciária em garantia: o sistema dicotômico da propriedade no Brasil. In: Revista de Direito Bancário 2008, n. 39, p. 57-78.

NORONHA, Fernando. Patrimônios Especiais: sem titular, autônomos e coletivos. In: Revista dos Tribunais, v. 747, ano 87, jan 1998, pp. 11-34.

NUNES, Pedro dos Reis. Dicionário de Tecnologia Jurídica, v. 2. $5^{\mathrm{a}}$ ed. Rio de Janeiro: Freitas Bastos, 1961.

NUZZO, Massimo. Negozio Fiduciario. In: Rivista di Diritto Civile 6/645, ano XXXI, nov e dez 1985.

PACHECO, José da Silva. Processo de Falência e Concordata: Comentários à Lei de Falências. 6 $6^{\text {a }}$ ed. Rio de Janeiro: Forense, 1996.

PAIVA, Luiz Fernando Valente de (Coord.). Direito Falimentar e a Nova Lei de Falências e Recuperação de Empresas: Lei 11.101 de 9 de Fevereiro de 2005 e LC 118 de 9 de Fevereiro de 2005. São Paulo: Quartier Latin, 2005. 
PANUCCIO, Vincenzo; La cessione volontaria dei crediti: nella teoria del trasferimento. Milano: Dott. A.Giuffrè, 1955.

PELUSO, Cezar. (Coord.). Código Civil Comentado: doutrina e jurisprudência, $3^{\mathrm{a}}$ ed. São Paulo: Manole, 2009.

PEREIRA, Caio Mario da Silva. Projeto de código de obrigações. Rio de Janeiro: Imprensa Nacional, 1965. . Instituições de direito civil, v. I - Introdução ao Direito Civil. Teoria Geral de Direito Civil, 21 a ed. Rio de Janeiro: Forense, 2006. Instituições de direito civil, v. II - Teoria Geral das Obrigações, 20ª ed. Rio de Janeiro: Forense, 2006. Instituições de direito civil, v. III - Contratos, $12^{\mathrm{a}}$ ed. Rio de Janeiro: Forense, 2006. Instituições de direito civil, v. IV - Direitos Reais, $19^{\mathrm{a}}$ ed. Rio de Janeiro: Forense, 2006.

PINTO, Carlos Alberto da Mota. Cessão de Contrato: contendo parte tratando a matéria conforme o direito brasileiro. São Paulo: Saraiva, 1985.

PONTES DE MIRANDA, Francisco Cavalcanti. Tratado de Direito Privado, Parte Geral, Tomo II. $4^{\text {a }}$ ed. São Paulo: Revista dos Tribunais, 1983.

Tratado de Direito Privado, Parte Geral, Tomo III. $4^{\mathrm{a}}$ ed. São Paulo: Revista dos Tribunais, 1983. . Tratado de Direito Privado, Parte Geral, Tomo V. $4^{\mathrm{a}}$ ed. São Paulo: Revista dos Tribunais, 1983. 
ed. São Paulo: Revista dos Tribunais, 1984.

Tratado de Direito Privado, Parte Especial, Tomo XXIII. $3^{\text {a }}$ ed. São Paulo: Revista dos Tribunais, 1984.

PRATA, Ana. Dicionário Jurídico: direito civil, direito processual civil, organização judiciária. $3^{a}$ ed. Coimbra: Almedina, 1992.

REGELSBERGER, Ferdinand. Zwei Beiträge zur Lehre von der Cession. In: Archiv für die civilistische "Praxis", v. 63, p. 157 e ss.

REQUIÃO, Rubens. Curso de Direito Falimentar, v. 1, 17ª ed. São Paulo: Saraiva, 1998.

RESTIFFE NETO, Paulo. Garantia fiduciária: direito e ações. São Paulo: Revista dos Tribunais, 1975 .

RESTIFFE, Paulo Sérgio. Alienação fiduciária e o fim da prisão civil. São Paulo: Revista dos Tribunais, 2007.

RESTIFFE, Paulo Sérgio. Propriedade Fiduciária Imóvel. São Paulo: Malheiros, 2009.

SALOMÃO NETO, Eduardo. O trust e o direito brasileiro. São Paulo: LTr, 1996.

SANTORO-PASSARELLI, Francesco. Interposizione di persona, Negozio Indiretto e Successione Della Prole Adulterina. In: Foro italiano, 1932, I.

SANTOS, João Manuel de Carvalho. Código Civil Brasileiro Interpretado, v. II. Rio de Janeiro: Freitas Bastos, 1982.

SANTOS, Joaquim Antonio Penalva. Obrigações e Contratos na Falência. Rio de Janeiro: Renovar, 1997. 
SANTOS, José Beleza dos. A Simulação em Direito Civil, $2^{\text {a }}$ ed. São Paulo: Lejus, 1999.

SCOTT, Austin Wakeman. The law of trusts. Boston: Little Brown, 1956.

SIDOU, J. M. Othon (org.). Dicionário Jurídico: Academia Brasileira de Letras. $7^{\text {a }}$ ed. Rio de Janeiro: Forense Universitária, 2001.

SILVA, De Plácido e. Vocabulário Jurídico - v. I e III. $8^{\mathrm{a}}$ ed. Rio de Janeiro: Forense, 1984.

SOUZA JUNIOR, Francisco Satiro de (Coord.); PITOMBO, Antonio Sergio A. de Moraes (Coord.); Comentários à Lei de Recuperação de Empresas e Falências. $2^{\mathrm{a}}$ ed. São Paulo: Revista dos Tribunais, 2007.

TALAVERA, Glauber M. O Negócio Fiduciário e a Recuperação Judicial. Artigo publicado no Jornal Valor Econômico de 29.01.2008.

TOLEDO, Paulo F. C. Salles de. Recuperação Judicial, a principal inovação da Lei de Recuperação de Empresas - LRE. In: Revista do Advogado $\mathrm{n}^{\circ}$ 83, ano XXV, Setembro de 2005, pp. 98-106.

- (Coord.); ABRÃO, Carlos Henrique (Coord.);

Comentários à Lei de Recuperação de Empresas e Falências. $2^{\mathrm{a}}$ ed. São Paulo: Saraiva, 2007.

VARELA, João de Matos Antunes. Das Obrigações em Geral, v. 2. Coimbra: Almedina, 1995.

VASCONCELOS, Luís Miguel Delgado Paredes Pestana de. A cessão de créditos em garantia e a insolvência - em particular da posição do cessionário na insolvência do cedente. Coimbra: Coimbra Editora, 2007.

VASCONCELOS, Pedro Pais de. Contratos Atípicos. Coimbra: Almedina, 1995. 
VENOSA, Silvio de Salvo. Direito Civil: teoria geral das obrigações e teoria geral dos contratos, v. II. $8^{\text {a }}$ ed. São Paulo: Atlas, 2009.

VIVANTE, Cesare. Trattato di diritto commerciale, v. III. 5ª ed. Milano: Vallardi, 1922.

VON TUHR, Andreas. Tratado de las Obligaciones, Tomo II, traduzido do alemão por W. Roces, Madrid: Editorial Reus, 1934.

Derecho Civil: Teoría General del Derecho Civil Alemán, v.1, traduzido do alemão para o espanhol por Tito Ravá. Madrid: Marcial Pons, 1998.

WAISBERG, Ivo (Coord.); FONTES, Marcos Rolim Fernandes (Coord). Contratos Bancários. São Paulo: Quartier Latin, 2006.

WALD, Arnoldo. Curso de Direito Civil Brasileiro - Obrigações e Contratos. $2^{\mathrm{a}}$ ed. São Paulo: Sugestões Literárias, 1969.

WULFF, Ulbert. Das Vollindossamen zu Incassozcwecken. Berlim, 1892. 